\title{
Včasnostredoveké sídlisko v Brne-Medlánkach
}

\author{
Early medieval settlement in Brno-Medlánky
}

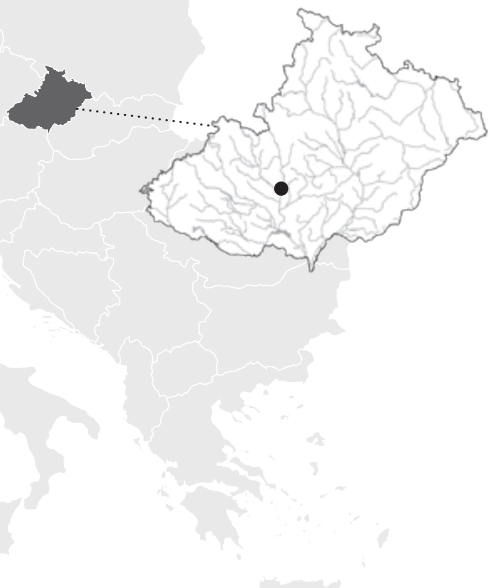

- Jakub Benech*-

\section{KEYWORDS}

Early Middle Ages - rural settlement - Moravia - material culture metallurgy.

\section{ABSTRACT}

The presented article examines the early medieval settlement in Brno-Medlánky. The archaeological finds were evaluated to obtain settlement spatial development and to reveal the practical, social and natural dimension of the settlement after the synthesis of the evidence. The relevance of the site in relation to early medieval Brno was also considered. The large quantity of ceramics, which was essential for this research, was processed using the database of J. Macháček. This enabled me to date the settlement between the 6th/7th to the 9th/10th century and, based on quantification, to characterise the morphological and technological features of the complex. The archaeological material was also compared with the material from other similar sites. The results of this analysis were acquired from data in the graphs, figures and quantification tables. The other findings were processed using descriptive models. Scientific analyses have proven the presence of blacksmithing and iron metallurgy at the site. Agricultural activities and processing of leather and textile were also documented at the site. The typical cumulative structure was evaluated within the framework of spatial analyses, together with the form and spatial development of the settlement. Moreover, the article deals with the complete skeletons of two dogs and one horse, and the human skeleton found in a storage pit. The complete animal skeletons were probably deposited for hygienic reasons; the human skeleton possibly proves an execution.

\footnotetext{
* Corresponding author - E-mail address: 429062@mail.muni.cz

https://doi.org/10.47382/pv0622-04

Received 16 July 2021; received in revised form 21 October 2021 Available online 30 December 2021
}

Copyright (c) 2021 Czech Acad Sci, Inst Archaeology Brno, and the authors.

This is an open access article under the CC BY-NC-ND 4.0 license

(https://creativecommons.org/licenses/by-nc-nd/4.0/).

Competing interests: The authors have declared that no competing interests exist.

\section{1. Úvod}

Včasnostredoveké osídlenie Brnenska je vel'mi pestré, sústredené okolo vodných tokov a tvorí severnú časť tzv. starej sídelnej oblasti Moravy. Objavuje sa tu najstaršia keramika pražského typu. Tá sa nachádzala v keramickom súbore, ktorý objavil J. Poulík na dnešnej Pisáreckej ulici (Hrubý 1961, 135-136). Včasná slovanská keramika bola nájdená aj na Dornychu na Ulici Př́zovej, v Bohuniciach či Brne-Holáskach (Přichystal 2009, 344; Procházka et al. 2011, 451). Osídlenie sa v oblasti Brna v priebehu starohradištnej doby zhustilo. Medzi viacerými drobnými lokalitami (Brno-Maloměřice, Dornych, Zábrdovice a iné) vyniká starohradištné sídlisko Brno-Starý Lískovec zo 7.-8./9. storočia. Na sídlisku bolo nájdených pät zahĺbených obydlí a významný keramický súbor (Čižmářová 1996, 271-279). Do starohradištnej doby boli datované aj lokality v blízkom okolí sídliska v Medlánkach. Ide o lokalitu Komín, poloha U hřbitova, ktorá je od sídliska vzdialená približne $1,5 \mathrm{~km}$ juhozápadne a Komín, poloha Štompil, ktorá leží juhozápadne od lokality na Ulici Sadovej, ležiacej od lokality smerom na východ. Obe sú vzdialené od medláneckého sídliska asi $2 \mathrm{~km}$. Rovnako sa do tohto obdobia datuje začiatok osídlenia ostrohu hradiska a regionálneho centra Staré Zámky u Líšně, vzdialeného od sídliska v Medlánkach približne $11 \mathrm{~km}$. Jeho počiatok je datovaný na prelom 7. a 8. storočia. Nálezy ostrôh s háčikmi a častí konského postroja či avarských liatych garnitúr dokladajú prítomnost’ vyššej spoločenskej vrstvy. Hradisko slúžilo ako regionálne centrum aj v období Vel'kej Moravy (Staňa 1985, 168-169), kedy bol región súčastou jej jadra. Počas 9. storočia sa rozšírilo o dve predhradia. Pribudol tiež vel'možský dvorec, ktorý spolu s nálezmi šperkov a bojovníckej výstroje dokladá pretrvávajúcu prítomnost̉ elít. Osídlenie pokračuje až do 11. storočia aj napriek jeho vypáleniu, pravdepodobne Mad’armi, na prelome 9. a 10. storočia (Staňa 1960, 240-291; 1972, 109-154; Fojtík et al. 2007, 462-463). Okolité lokality zo strednej doby hradištnej pozostávajú prevažne z hrobových celkov a začínajú vykazovat sociálnu diferenciáciu spoločnosti. Medzi významné patria hroby z lokalít Brno-Ivanovice, Brno-Holásky, Brno-Maloměřice a iné. Hroby okrem militárií obsahovali šperky či keramiku blučinského výrobného okruhu. Významnejšie sídlisko s drevo-hlinitým opevnením sa našlo pod Ulicou Kř́žzovou, Kř́ídlovicou a Ypsilantiho, kde bola doložená intenzívna kováčska výroba. Najbližšia stredohradištná lokalita k sídlisku v Medlánkach je Brno-Řečkovice, náměstí Palackého, vzdialená asi $2 \mathrm{~km}$ severne od sídliska (Procházka et al. 2011, 454-495, obr. 155).

Včasnostredoveké sídlisko v Brne-Medlánkach nebolo aj napriek dostupnosti a zachovalosti archeologického materiálu dodnes komplexnejšie spracované. Je mu venovaná časť v magisterskej diplomovej práci D. Zapletalovej, ktorá rozoberá 
keramický materiál zo staršieho výskumu (Zapletalová 2001, 125-135). Zmienka o sídlisku sa nachádza aj v 1. časti rozsiahlej práce Dějiny Brna (Procházka et al. 2011, 447-560), kde bola tiež zdôraznená potreba jeho komplexnejšieho vyhodnotenia. Ked'že autorkou tejto časti kapitoly je D. Zapletalová, datovanie sídliska sa v nej zhoduje so závermi jej diplomovej práce. Tie sú však doplnené o nový záchranný výskum druhej časti sídliska z roku 2007 (Geisler 2008b, 393-394). Datovanie sídliska podl’a D. Zapletalovej teda začína od obdobia kultúry s keramikou pražského typu kontinuálne až do strednej doby hradištnej. Z nej bol zaznamenaný výskyt derivátov keramiky blučinského a možno aj dolnověstonického výrobného okruhu (Procházka et al. 2011, 451, 457, 481-482). Svojim dielom k poznaniu archeologickej situácie prispel aj článok Z. Berkovej a D. Parmu (2013, 71-152), ktorý je venovaný nálezom a objektom z mladšej a neskorej doby bronzovej z výskumov v Brne-Medlánkach a blízkeho okolia. Posledná zmienka o lokalite bola v magisterskej diplomovej práci K. Piačkovej (2018, 61-62), kde je krátka stat o l'udských pozostatkoch v zásobnici objavených počas výskumu v roku 2007.

Hlavným ciel’om štúdie je na základe spracovania archeologických nálezov a jednotlivých objektov rekonštruovat časopriestorový vývoj sídliska a jeho ekonomicko-sociálnu charakteristiku. Pre splnenie tohto zámeru je potrebné zodpovedat niekol'ko čiastkových výskumných otázok. Prvou je otázka relatívneho datovania objektov a ich časovej súvislosti medzi sebou navzájom, a to na základe keramiky. Na to nadväzuje otázka rekonštrukcie priestorovej štruktúry sídliska a podoby stavieb, ktoré ho tvorili. Tretia otázka má za ciel' rekonštruovat výrobnú činnost', jej podobu, rozsah na sídlisku, ako aj jej širšie postavenie v priestore Brnenskej oblasti. Ďalšia otázka sa týka podoby spoločnosti, jej usporiadania, resp. toho, čo nám k nej nálezy zo sídliska vedia povedat'. Posledná otázka je otázka paralel či odlišností s inými podobnými včasnostredovekými sídliskami. Účelom výskumných otázok je poskladat z dostupných informácii mozaiku, ktorá by čo najlepšie charakterizovala všetky aspekty včasnostredovekého sídliska v Brne-Medlánkach ako takého. $\mathrm{V}$ tejto úlohe však čiastočne bránila skutočnosṫ, že materiál z výskumu z roku 2007 bol zasiahnutý povodňou v depozitári Ústavu archeologické památkové péče Brno v Bílovicích nad Svitavou, a preto sú mnohé nálezy stratené a mnohé môžu byt pomiešané. Z materiálu z výskumu z roku 1984 sa tiež stratilo niekol'ko dôležitých kusov keramiky.

\section{Dejiny výskumu}

Prvý záchranný výskum sa na lokalite Brno-Medlánky konal v gescii Archeologického ústavu ČSAV pod vedením M. Geislera a za spolupráce J. Ř́hovského, a to v júli a auguste v roku 1984. Bol realizovaný v rámci stavby výrobnej haly národného podniku Meopta Přerov v Medlánkach v Brne. Počas výskumu bola odkrytá južná plocha spolu s menšou plochou obdížnikového tvaru východne od nej. Lokalita s rozlohou približne 3 ha bola situovaná na južnom cípe vnútornej časti Brna-Medlánok na trati Zadní žleby (obr. 1). Tá leží na miernom sprašovom svahu, ktorý je orientovaný východným a juhovýchodným smerom v nadmorskej výške 260-265 m. Najbližší vodný tok Medlánecký potok, v súčasnosti kanalizovaný, je od lokality vzdialený vzdušnou čiarou 750-800 m, severovýchodným smerom. Nie je vylúčené, že v minulosti pozdíž južnej strany lokality pretekal jeho prítok. Plocha bola husto pokrytá archeologickými objektmi velatickej kultúry (mladšia doba bronzová) a včasnostredovekými objektmi, ktorých bolo dohromady 109. Do velatickej fázy osídlenia lokality bolo zaradených 31 objektov a do včasného stredoveku 66 objektov. Z toho osem chát bolo zahíbených a zvyšok tvorili podlahy ako relikt nadzemnej stavby. Jeden objekt s neurčitým materiálom prináleží asi únětickej kultúre (staršia doba bronzová). Ostatné objekty boli bez nálezov, preto ich nebolo možné datovat'. Vzhl'adom k rýchlemu priebehu stavebných prác bola podrobnejšie preskúmaná iba stredná a západná čast’ lokality, asi polovica odkrytej plochy. Východná čast̉ bola sledovaná výberovo, skôr formou sondáží či povrchového zberu. Plocha bola odkrytá mechanicky, systematicky, začistená bola iba čast̉ s doloženými nadzemnými stavbami. Zvyšná plocha bola presondovaná l’ahkým zemným strojom. Táto metóda, bežná v rámci záchranných výskumov, má za následok stratu

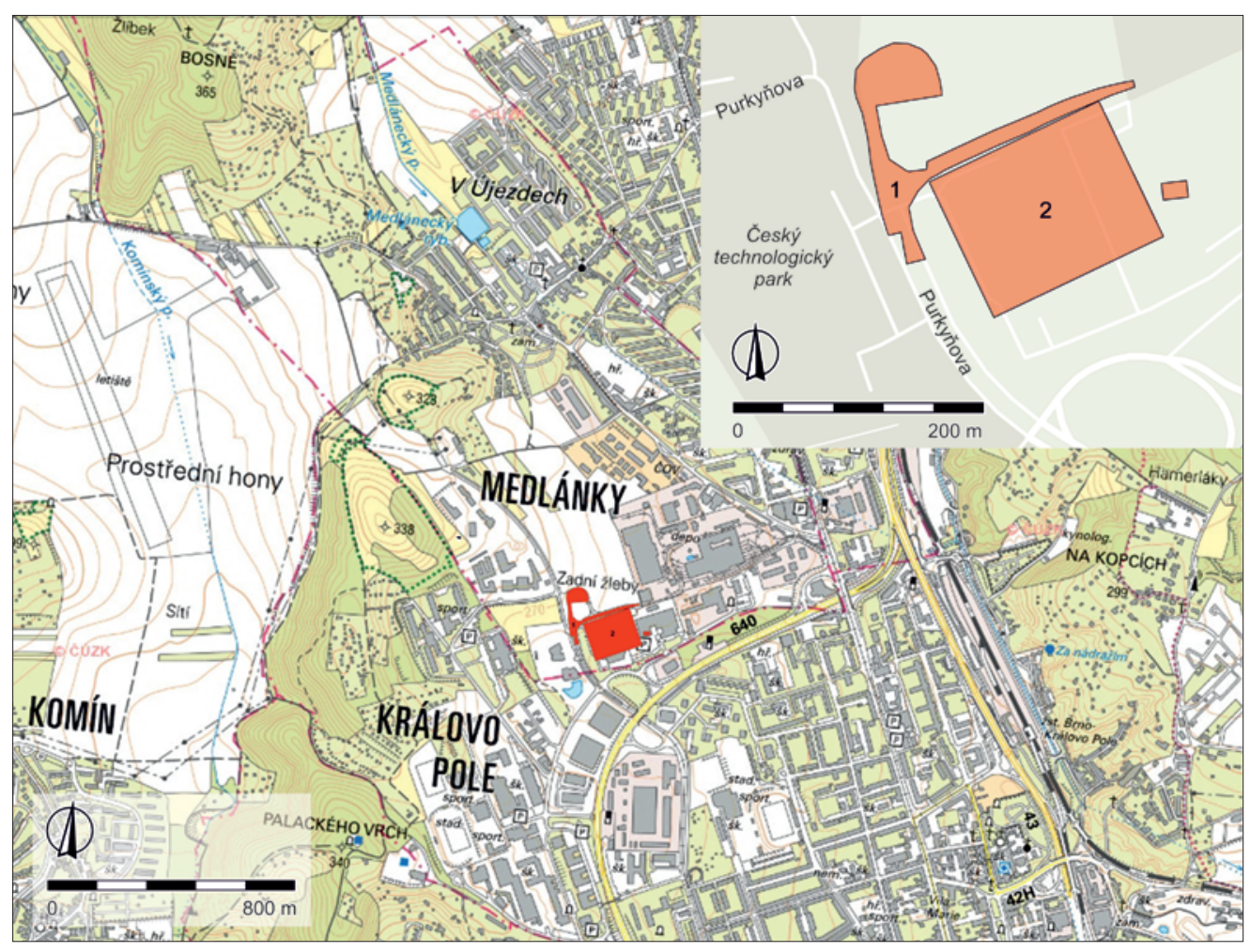

Obr. 1. Poloha sídliska. 1 - Severná plocha - výskum 2007; 2 - južná plocha - výskum 1984. Český ústav zeměměřičský a katastrální (ČÚZK-Data200).

Fig. 1. Position of settlement. 1 - North area - excavation in 2007; 2 - south area - excavation in 1984. Czech Office for Surveying, Mapping and Cadastre (ČÚZK-Data200). 
väčšiny nálezov nachádzajúcich sa v ornici. Taktiež je možné, že v niektorých miestach boli takýmto spôsobom odstránené horné časti objektov. Okrem uhlíkov a ulít neboli odoberané žiadne vzorky (Geisler 1987, 74-75; 1992, 1-2). Druhý výskum realizoval Ústav archeologické památkové péče Brno, tiež pod vedením M. Geislera. Uskutočnil sa od apríla do novembra v roku 2007, pričom bola odkrytá severná plocha sídliska, a to opät na trati Zadní žleby. Výskum bol vyvolaný druhou etapou stavby rampy mimoúrovňového kríženia Ulíc Hradecká-Purkyňova, ktorá predížila trat električky na k. ú. Královo Pole a Medlánky. Nemal podobu klasického súvislého plošného výskumu, ale rozsiahlych sond. Hranica sídliska bola archeologicky objavená snád’ len na severe. Okrem objektov zo strednej doby hradištnej bola zastúpená tiež velatická kultúra a kultúra stredodunajských popolnicových polí. Celkovo bolo odkrytých 84 objektov, z toho 31 bolo datovaných do doby hradištnej, vrátane jednej zahíbenej chaty s kamenným krbom (Geisler 2008a, 4-7). Na lokalite bol zaznamenaný aj lomený zákop z obdobia 2. svetovej vojny. Plocha bola mechanicky zbavená ornice a následne ručne začistená. Odoberané boli vzorky uhlíkov, ulít a kameňov (Geisler 2008a, 1-7; 2008b, 393-394; Geislerová, Parma eds. 2013, 218-219).

\section{Metóda práce}

Sídlisko v Brne-Medlánkach bolo spracované na základe archeologického materiálu získaného počas výskumov v rokoch 1984 a 2007. Analyzovaná bola v rámci metódy formulovanej E. Neustupným (1986, 532-542; 1994), so zretel’om na kresbovú a fotografickú dokumentáciu lokality a archeologických objektov, ktorá je obsiahnutá v nálezových správach (Geisler 1992; 2008a). Keramika bola analyzovaná pomocou databázy v programe Microsoft Office Access 2007. Autor originálnej databázy je J. Macháček, ktorý ju vypracoval za účelom spracovania vel'komoravskej keramiky (je aplikovatel'ná aj na predvel'komoravskú keramiku a keramiku pražského typu) z lokality Břeclav-Pohansko Lesní školka (Macháček 2001, 42-66). Táto databáza umožňuje kvalitatívne aj kvantitatívne vyhodnotenie vel'kých keramických súborov. To ul'ahčilo interpretáciu, tvorbu archeologických modelov a datovanie sídliska. Na kvantifikáciu výsledkov boli použité tabul'ky v programe Microsoft Office Excel 2007. Na analýzu keramiky ako odpadu bola použitá kategorizácia M. Kuny (2015, 280-287). Zatial’ čo $\mathrm{v}$ rámci starého výskumu boli ponechané pôvodné čísla objektov, vzhl'adom k inému spôsobu dokumentácie, pri novom výskume boli objektom priradené nové čísla namiesto kombinácie čísla výkopu a výplne. Čísla priamo nadväzujú na číslovanie starého výskumu a ich stotožnenie s pôvodnými číslami výkopu a výplne sa nachádza v záverečnom katalógu (tab. 22). Nový výskum bol totiž dokumentovaný tzv. formulárovou metódou, ktorá je odlišná číslovaním aj rozlišovaním výplne a výkopu. Jednotlivé vrstvy objektov neboli nájdené ani pri jednom výskume. To nám znemožnilo akékol’vek úvahy nad charakterom zapíňania objektov, procese ich zániku či sekundárneho využitia. Výnimku tvorí situácia objektov 111, 113 a 128, kde sa vrstvy podarilo objavit'. Drobné nálezy boli spracované pomocou používaných deskriptívnych systémov, ktoré sú citované v rámci príslušných statí nižšie. Zvieracie kosti boli analyzované G. Dreslerovou (2020, 43-52) a troska M. Kmoškom ako nepublikovaná analýza. Petrografickú analýzu praslenov a žarnovov vykonal A. Přichystal ako samostatný nepublikovaný posudok.

Geografické dáta z nového výskumu nám poskytla D. Vitulová a zo staršieho D. Parma z Ústavu archeologické památkové péče v Brne, v. v. i. Na tvorbu priestorových modelov sídliska v Brne-Medlánkach boli použité geografické informačné systémy (d’alej už len GIS), konkrétne program ArcGIS ArcMap 10.5.
Priestorové modely boli vypracované za pomoci P. Dreslera a M. Mudrika, ktorým by som rád pod’akoval. V záverečných výstupoch je sídlisko priestorovo zobrazené a zachytená je aj jeho štruktúra, prípadne koncentrácia nálezov podla objektov. Výsledkom príspevku je charakteristika prírodného, praktického (výrobná činnost̉) a spoločenského rozmeru sídliska na základe nálezov a priestorových štruktúr tak, ako ich formuloval E. Neustupný (1994, 248-258).

\section{Prírodné pomery}

Oblast' Brna leží na hranici dvoch vel'kých geologických celkov, Západných Karpát a Českého masívu, ku ktorému patrí západná čast̉ Brna s dominantami Špilberk či Petrov. Medzi časté nerudné materiály využívané človekom $\mathrm{v}$ tejto oblasti patria rohovce, krinoidové vápence, kremenné zlepence, granodiority, tretohorné piesky a spraš (Přichystal 2011, 19-21). Samotná lokalita sa taktiež nachádza viac ako 11 km južne od Moravského krasu. Ten bol povestný množstvom ložísk železnej rudy. Doklady jej spracovania siahajú až do 8. storočia (Souchopová 1995, 41). Charakter povrchových vôd determinuje vel'mi malú retenčnú schopnost krajiny a kolísavý odtok. Siet vodných tokov tvoria rieky Svratka od severozápadu smerom k východu, Svitava pretekajúca zo severu na juh s prítokom Ponávky, pripájajúcej sa zo severu na l'avobreží. Zvyšok oblasti pokrývajú len drobné potoky. V južnej časti mesta prevládajú vel'mi úrodné černozeme, miestami černice, na sprašových sedimentoch sa vytvorili aj hnedozeme. Tie sú vhodné k obrábaniu a leží na nich aj skúmané sídlisko (ČGS-Půdy; Buček, Kirchner 2011, 47-50, 61, 67-68). Antrakologický materiál dokladá (tab. 1), že oblaste patrí do dubovo-bukového vegetačného stupňa.

\begin{tabular}{lr}
\hline Druh & Kusy \\
\hline Dub (Quercus sp.) & 265 \\
\hline Buk (Fagus silvatica) & 18 \\
\hline Jedl'a (Abies alba) & 4 \\
\hline Lieska (Corylus avellana) & 1 \\
\hline Topol'/Vŕba (Populus/Salix) & 1 \\
\hline Lipa (Tila sp.) & 1 \\
\hline Javor (Acer sp.) & 2 \\
\hline
\end{tabular}

Tab. 1. Vyhodnotené vzorky uhlíkov zo slovanských objektov.

Tab. 1. Evaluated samples of charcoals from early medieval features.

Ako už bolo spomenuté v úvode, včasnostredoveké sídlisko leží na južnom cípe vnútornej časti Brna-Medlánok na trati Zadní žleby. Najbližší vodný tok je Medlánecký potok, ktorý je v súčasnosti kanalizovaný a od lokality vzdialený približne 750-800 m severovýchodným smerom. Nie je vylúčené, že v minulosti pozdíž južnej strany lokality pretekal jeho prítok prameniaci na Kozej Hore a vlieval sa do Medláneckého potoka z pravého brehu. Tento stav naznačujú okolité lokality doby bronzovej a halštatskej, ležiace 100-400 m juhovýchodne od sídliska, ktoré svojím postavením navodzujú dojem súvislého osídlenia l'avobrežnej terasy spomínaného toku (Salaš, Stuchlík 2011, 232-313, obr. 147, 148). Včasnostredoveké sídlisko leží v blízkosti metabazaltovej (metabazitovej) zóny. Je situované na kvartérnych sprašových sedimentoch v blízkosti holocénnej hlinito-piesčitej riečnej naplaveniny na rozhraní Palackého hřbetu a Medláneckej sníženiny, ktoré sú súčastou Lipovskej vrchoviny, geomorfologického okrsku Brnenskej vrchoviny a zároveň súčastou Českého masívu (Přichystal 2011, obr. 131, 135, 137; Novák, Hanžl 1992, 5).

Práve na úrodnej hnedozemi Medláneckej sníženiny, ktorá leží na sprašovom podloží, môžeme v zovretí Palackého hřbetu 


\begin{tabular}{|c|c|c|}
\hline Č. obj. & Druh & Kusy \\
\hline 9 & Dub (Quercus sp.) & 4 \\
\hline 14 & Dub (Quercus sp.) & 11 \\
\hline 19 & Dub (Quercus sp.) & 1 \\
\hline \multirow[t]{4}{*}{21} & Dub (Quercus sp.) & drt' cca 300 \\
\hline & Topol'/Vŕba (Populus/Salix) & 5 \\
\hline & Buk (Fagus silvatica) & 1 \\
\hline & Jedl'a (Abies alba) & 1 \\
\hline \multirow[t]{2}{*}{31} & Dub (Quercussp.) & 8 \\
\hline & Jedl'a (Abies alba) & 3 \\
\hline 32 & Dub (Quercus sp.) & 3 \\
\hline 33 & Dub (Quercus sp.) & drt \\
\hline \multirow[t]{2}{*}{44} & Dub (Quercus sp.) & 1 \\
\hline & Buk (Fagus silvatica) & 1 \\
\hline \multirow[t]{2}{*}{58} & Dub (Quercus sp.) & 4 \\
\hline & Topol'/Vŕba (Populus/Salix) & 1 \\
\hline \multirow[t]{2}{*}{65} & Dub (Quercus sp.) & 17 \\
\hline & Buk (Fagus silvatica) & 9 \\
\hline \multirow[t]{2}{*}{69} & Dub (Quercus sp.) & 7 \\
\hline & Buk (Fagus silvatica) & 3 \\
\hline
\end{tabular}

Tab. 2. Zastúpenie druhov stromov podl’a vzoriek uhlíkov.

Tab. 2. Total occurrence of tree species according to charcoal pieces.

z juhovýchodu a Babího hřbetu zo severozápadu predpokladat polohu pol'nohospodársky obrábanej pôdy. Jej tažisko sa snád' rozprestieralo na východnom svahu, ktorý priliehal k Medláneckému potoku. Celá oblast̉ bola odjakživa bohatá na zásoby vody. Ide o tok ned'alekého potoka a taktiež mokrade, nachádzajúce sa severne od vrchu Bosně, v polohe U Pergla, na okraji vyvýšenej polohy V Markrabství. Mokrad’ zanikla v 50. rokoch počas kolektivizácie a vodu zadržiavalo nepriepustné podložie. Vrch Bosně (365 m n. m.) zároveň ohraničoval pol'nohospodársku pôdu zo severovýchodnej strany. Na západe bola ohraničená miernym návrším (338-340 m n. m.), ktoré sa tiahne až k juhozápadu Palackého vrchu (340 m n. m.). Za ním sa už rozprestierala pôda obrábaná osadami v oblasti Brno-Komín. Hranica z juhu je neistá. Nadmorská výška zníženiny sa pohybuje medzi 223-322 m a je pol’nohospodársky využívaná dokonca aj v súčasnosti (ČÚZK-Data200; Buček, Kirchner 2011, 61; Braun, Fuchs 1992, 8, 11).

K čiastočnej rekonštrukcii flóry v okolí sídliska poslúžili z archeologických objektov vzorky uhlíkov (tab. 2). Spracované boli iba tie, ktoré pochádzali zo staršej fázy výskumu. Jedna vzorka zodpovedá jednému kusu uhlíku s výnimkou uhlíkovej drte v obj. 21 a 33. Antrakologické výsledky sú uvedené v nálezovej správe, z ktorej však nie je jasné, kto je autorom určenia (Geisler 1992, 3-114), pravdepodobne je ním E. Opravil. K našej analýze použijeme iba vzorky pochádzajúce z včasnostredovekých objektov.

Z grafu (graf 1) je zretel'ná absolútna prevaha duba (Quercus sp.), ktorá spolu s početnejším výskytom buka (Fagus silvatica) dokladá zaradenie oblasti do dubovo-bukového vegetačného stupňa. Ostatné dreviny doložené na sídlisku sa vyskytujú len vo vel'mi malých množstvách. Do štatistiky neboli zaradené vzorky z obj. 21, nakol'ko ich vzhl'adom k povahe objektu radíme do pozostatkov remeselnej činnosti. Aj tam je však vidiet? absolútnu prevahu duba, ktorú tvorí vrstva uhlíkov (odobraných 300 kusov). Diagram má len obraznú výpovednú hodnotu, pretože zbery uhlíkov boli náhodné.

Tieto výsledky zodpovedajú aj paleobotanickým výskumom v oblasti Brnenska. Na lokalite Staré Zámky u Líšně v dobe hradištnej výrazne prevláda dub (Quercus sp.), za ním je asi v polovičnom množstve zastúpený buk (Fagus silvatica). V malom rozsahu sú zastúpené aj iné stromy, napr. jedl’a (Abies alba), topol' (Populus) či vŕba (Salix). Tie sa v rovnako nízkom počte objavovali aj na medláneckom sídlisku (Opravil 1967, 92-94).

\begin{tabular}{|c|c|c|}
\hline Č. obj. & Druh & Kusy \\
\hline 73 & Dub (Quercus sp.) & 1 \\
\hline \multirow[t]{2}{*}{79} & Dub (Quercus sp.) & 4 \\
\hline & Lieska (Corylus avellana) & 1 \\
\hline 83 & Dub (Quercussp.) & 3 \\
\hline \multirow[t]{2}{*}{86} & Dub (Quercus sp.) & 32 \\
\hline & Buk (Fagus silvatica) & 1 \\
\hline \multirow[t]{2}{*}{93} & Dub (Quercus sp.) & 2 \\
\hline & Lipa (Tila sp.) & 1 \\
\hline \multirow[t]{4}{*}{95} & Dub (Quercus sp.) & 71 \\
\hline & Buk (Fagus silvatica) & 2 \\
\hline & Javor (Acer sp.) & 2 \\
\hline & Jedl'a (Abies alba) & 1 \\
\hline \multirow[t]{2}{*}{99} & Dub (Quercussp.) & 4 \\
\hline & Buk (Fagus silvatica) & 1 \\
\hline 101 & Dub (Quercus sp.) & 7 \\
\hline \multirow[t]{2}{*}{104} & Dub (Quercussp.) & 72 \\
\hline & Buk (Fagus silvatica) & 1 \\
\hline 106 & Dub (Quercus sp.) & 18 \\
\hline
\end{tabular}

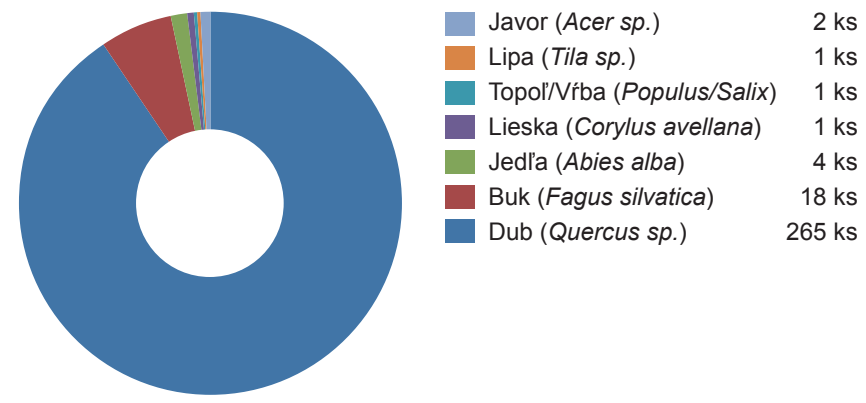

Graf 1. Zastúpenie druhov stromov podl’a antrakologického vyhodnotenia. Graph 1. Representation of tree species according to the anthracological analysis.

\section{Podoba stavieb na sídlisku}

Slovanské sídlisko v Brne-Medlánkach je typickou včasnostredovekou lokalitou vidieckeho charakteru. Aj napriek tomu, že bola preskúmaná iba čast sídliska, bolo odkrytých devät chát a zvyšok podlahy, pravdepodobne ako relikt nadzemnej stavby (obj. 5, 19, 58, 62, 70, 79, 83, 84, 101, 128) a 30 zásobných jám. Jednotlivé chaty boli typologicky zaradené podl'a systematiky P. Šalkovského (2001, 16-69, obr. 1). Híbka jednotlivých objektov bola meraná od úrovne začistenej plochy.

\section{Obj. 5 - chata}

Rozmery: $370 \times 330$ cm, híbka 20 cm.

Rok výskumu: 1984.

Tvar: pravidelný obdížnikový, mierne šikmé steny, ploché dno. Zásyp: hlinitý, tmavohnedý.

Popis: okrem sídliskovej jamy (obj. 6, hĺbka $40 \mathrm{~cm}$ ), ktorá zasahovala východný okraj chaty sa v nej nachádzali tri kolové jamy, na južnej (híbka $30 \mathrm{~cm}$ ), východnej (híbka $60 \mathrm{~cm}$ ) aj západnej (híbka $70 \mathrm{~cm}$ ) strane. Kolové jamy ležali v strede strán. Ich priemer nebol zaznamenaný a zvyšky po výhrevnom zariadení neboli nájdené. Chatu je možné hypoteticky zaradit do skupiny 1Ba2 (obr. 2). 

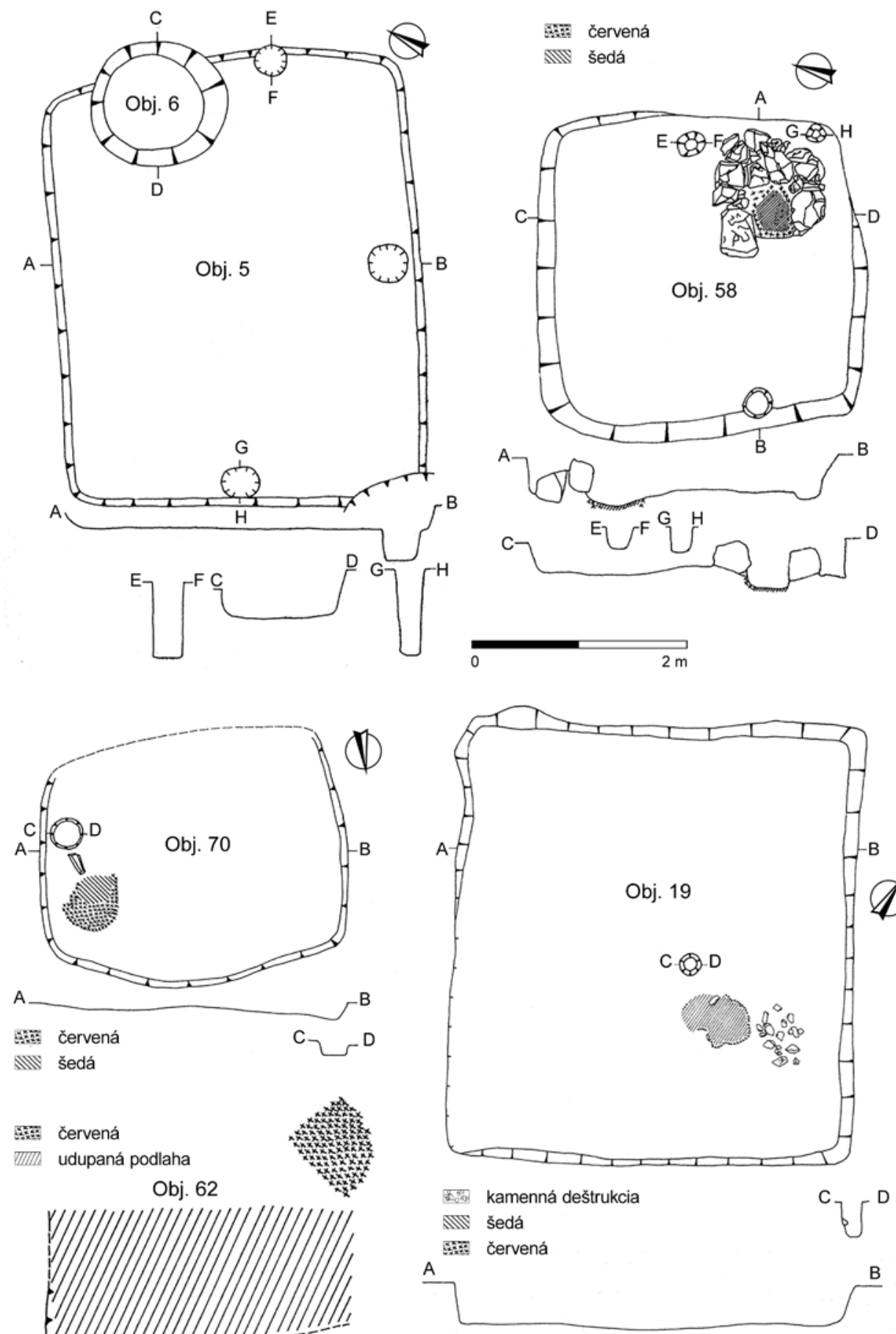

Obr. 2. Objekty 5, 6, 19, 58, 62, 70 Podl'a Geisler 1992, obr. 3, 11, 35, $36,39$.

Fig. 2. Features $5,6,19,58,62,70$ After Geisler 1992, Fig. 3, 11, 35, 36, 39

Obj. 19 - chata

Rozmery: $440 \times 400 \mathrm{~cm}$, híbka 15-50 cm.

Rok výskumu: 1984.

Tvar: štvorcový, mierne šikmé steny, ploché dno.

Zásyp: šedočierny.

Popis: približne v strede objektu sa nachádzala jedna kolová jamka (priemer $20 \mathrm{~cm}$, híbka $34 \mathrm{~cm}$ ). Bola pozoruhodne blízko ku kamennému výhrevnému zariadeniu v juhovýchodnom sektore. Objavený bol aj zvyšok prepálenej podlahy, tvorenej v strede šedočiernou a po obvode červenou vypálenou mazanicou $(70 \times 50 \mathrm{~cm})$. Kamenná deštrukcia ležala asi $15 \mathrm{~cm}$ vedl'a prepálenej plochy. Chatu možno spol'ahlivo zaradit do skupiny 1Ba1 (obr. 2). Objekt bol na základe keramiky datovaný do stredohradištného obdobia (pozri nižšie).
Obj. 58 - chata

Rozmery: $300 \times 312$ cm, híbka 30 cm.

Rok výskumu: 1984.

Tvar: štvorcový, šikmé steny (v juhovýchodnom rohu zvislé), ploché dno.

Zásyp: šedohnedý.

Popis: v chate sa nachádzali tri kolové jamky, jedna na západnej (priemer $28 \mathrm{~cm}$, híbka $8 \mathrm{~cm}$ ) jedna na východnej (priemer $25 \mathrm{~cm}$, híbka $22 \mathrm{~cm}$ ) a juhovýchodnej (priemer $18 \mathrm{~cm}$, híbka $24 \mathrm{~cm}$ ) strane. Kamenné výhrevné zariadenie ležalo taktiež vjuhovýchodnom rohu a tvorili ho kamene s vel'kostou asi $40 \times 30 \times 30 \mathrm{~cm}$. Na vrchu však bolo zasypané drobným kamením. Jeho deštrukcia zaberala takmer celý juhovýchodný sektor objektu. Išlo o podkovovité výhrevné zariadenie $(120 \times 110 \mathrm{~cm})$, 
otvorené smerom na západ. Jeho dno $(38 \times 40 \mathrm{~cm})$ bolo tvorené šedou a po obvode červenou vypálenou mazanicou, prekrytou vrstvou popola. Zapustené bolo $15-20 \mathrm{~cm}$ pod úroveň podlahy objektu. V jeho deštrukcii, hlavne pri ústi, boli nájdené kusy keramiky. Chata by mohla byt zaradená do skupiny 1Bb4 (obr. 2).

Obj. 62 - relikt nadzemnej stavby

Rozmery: nezistené.

Rok výskumu: 1984.

Tvar: pravouhlý.

Zásyp: nezistené.

Popis: relikt bol zahíbený do sprašového podložia len vel'mi plytko. Ležal pri ňom prepálený zvyšok dna ohniska. Objekt bol nekompletný a výrazne poškodený odkryvom. Z toho dôvodu je nemožné zaradit ho do typológie stavieb (obr. 2).

Obj. 70 - chata

Rozmery: $280 \times 240$ cm, híbka 0-16 cm.

Rok výskumu: 1984.

Tvar: oválny, nekompletne zachytený, západná a severná stena mierne zaoblená, ploché dno.

Zásyp: šedý.

Popis: do podložia bola chata zahíbená len čiastočne. Južná stena bola pri skrývke odobratá. Nachádzala sa v nej jedna kolová jamka (priemer $30 \mathrm{~cm}$, híbka $12 \mathrm{~cm}$ ) na východnej strane. Vedl’a sa na úrovni podlahy nachádzalo výhrevné zariadenie, objavené v severovýchodnom sektore v podobe prepálenej hliny. V strede bolo tvorené šedou a po obvode červenou vypálenou mazanicou. Z konštrukcie samotného výhrevného zariadenia sa zachoval iba jeden kameň. To značí, že mohlo íst’ o ohnisko. Chata patrí do skupiny $1 \mathrm{Ba} 1$ (obr. 2).

Obj. 79 - chata

Rozmery: $360 \times 330 \mathrm{~cm}$, híbka $16 \mathrm{~cm}$.

Rok výskumu: 1984.

Tvar: štvorcový, steny zvislé, ploché dno.

Zásyp: nezistené.

Popis: v chate sa nachádzalo osem kolových jamiek. Štyri v rohoch vnútri objektu a štyri po stranách čiastočne presahujúce hranicu objektu (priemer 22-38 cm, híbka 12-20 cm). Kamenné výhrevné zariadenie $(84 \times 80 \mathrm{~cm})$ bolo situované v juhovýchodnom rohu. Jeho konštrukcia pozostávala z kamenných dosiek postavených na výšku do tvaru podkovy. Ústie bolo orientované na západ. Vnútorný priestor bol prepálený v strede do šeda a po okrajoch do červena. Celý priestor bol pokrytý drobným kamením. Bez pochybností možno chatu zaradit do skupiny 1Bb8 (obr. 3). Objekt bol na základe keramiky datovaný do starohradištného obdobia (pozri nižšie).

Obj. 83 - chata

Rozmery: $338 \times 300$ cm, východná stena 240 cm, híbka 20-38 cm. Rok výskumu: 1984.

Tvar: lichobežníkový, šikmé steny, dno sa smerom od stredu mierne zvažovalo.

Zásyp: nezistené.

Popis: v chate sa nachádzali tri kolové jamky. Jedna v strede južnej (priemer $30 \mathrm{~cm}$, híbka $26 \mathrm{~cm}$ ), druhá východnej (priemer $30 \mathrm{~cm}$, híbka $8 \mathrm{~cm}$ ) a tretia v strede západnej strany (priemer $30 \mathrm{~cm}$, híbka $10 \mathrm{~cm})$. Zvyšky výhrevného zariadenia $(50 \times 40 \mathrm{~cm})$ ležali v severovýchodnom rohu na úrovni podlahy. Zariadenie bolo doložené šedou a po obvode červenou vypálenou mazanicou pokrytou drobným kamením. V juhovýchodnom rohu chaty ležala jama $(70 \times 96 \mathrm{~cm}$, dno $94 \times 100 \mathrm{~cm}$, híbka $80 \mathrm{~cm})$ s plochým dnom, so zvislou stenou orientovanou do chaty a s vakovito previsnutou stenou smerom von. Približne v strede chaty sa nachádzal zahíbený objekt so šikmými stenami a plochým dnom (priemer $70 \mathrm{~cm}$, piemer dna $42 \mathrm{~cm}$, híbka $28 \mathrm{~cm}$ ). Chata bola zaradená do skupiny 1Bb4 (obr. 4). Objekt bol na základe keramiky datovaný do starohradištného obdobia (pozri nižšie).

Obj. 84 - chata

Rozmery: $364 \times 326 \mathrm{~cm}$, híbka 20-45 cm.

Rok výskumu: 1984.

Tvar: obdížnikový, steny zvislé, ploché dno.

Zásyp: nezistené.

Popis: v chate sa nachádzali dve kolové jamky. Jedna na juhu (priemer $24 \mathrm{~cm}$, híbka $26 \mathrm{~cm})$, druhá na západe $(40 \times 26 \mathrm{~cm}$, híbka $44 \mathrm{~cm}$ ) prakticky v stene chaty, čiastočne vyplnená kameňmi. Zvyšky zahíbeného ohniska ležali v severovýchodnom rohu v nepravidelnej štvorcovej jame $(100 \times 100 \mathrm{~cm})$ so šikmými stenami a plochým dnom $(60 \times 50 \mathrm{~cm})$, po obvode vypáleným do červena a v strede do šeda. Pôvodná konštrukcia bola doložená len malým počtom kameňov. Chata patrí do skupiny $1 \mathrm{Ba} 2$ (obr. 3). Objekt bol na základe keramiky datovaný do stredohradištného obdobia (pozri nižšie).

Obj. 101 - chata

Rozmery: $300 \times 280 \mathrm{~cm}$, híbka $30 \mathrm{~cm}$.

Rok výskumu: 1984.

Tvar: štvorcový, šikmé steny, ploché dno.

Zásyp: nezistené.

Popis: v chate sa nachádzali štyri kolové jamky. Jedna pri severnej stene priamo pri výhrevnom zariadení (priemer $30 \mathrm{~cm}$, híbka $14 \mathrm{~cm}$ ), druhá v strede V (priemer $30 \mathrm{~cm}$, híbka $42 \mathrm{~cm}$ ) a tretia v strede západnej steny (priemer $36 \mathrm{~cm}$, híbka $50 \mathrm{~cm}$ ). Posledná bola pri strede južnej steny (priemer $30 \mathrm{~cm}$, híbka $15 \mathrm{~cm}$ ). V jej blízkosti sa ešte nachádzala jama s misovitým dnom (priemer $70 \mathrm{~cm}$, híbka $30 \mathrm{~cm}$ ). Kamenné výhrevné zariadenie ležalo v severovýchodnom rohu a bolo zapustené $20 \mathrm{~cm}$ pod úroveň podlahy. Jeho dno $(55 \times 55 \mathrm{~cm})$ bolo tvorené šedou a po obvode červenou vypálenou mazanicou. Z kamennej konštrukcie sa zachovalo iba pár rozptýlených kameňov. Ústie bolo zrejme orientované na juh. V severovýchodnom sektore sa tiež nachádzala výrazná vrstva uhlíkov $(170 \times 80 \mathrm{~cm})$ prekrytá sprašou. Súčast̉ou chaty bola aj zásobnica (obj. 104, priemer $110 \mathrm{~cm}$, híbka $220 \mathrm{~cm}$ ), ktorá ležala pri južnej stene a výrazne vytŕčala z pôdorysu chaty. Vd'aka spoločnej hornej vrstve zásypu je možné povedat', že oba objekty boli súčasné. Chata patrí do skupiny $1 \mathrm{Ba} 2$ (obr. 3). Objekt bol na základe keramiky datovaný do starohradištného obdobia (pozri nižšie).

Obj. 128 - chata

Rozmery: $500 \times 550 \mathrm{~cm}$, samotná chata $380 \times 380 \mathrm{~cm}$, híbka $100 \mathrm{~cm}$.

Rok výskumu: 2007.

Tvar: nepravidelný štorcový, chata mala šikmé steny a ploché dno.

Zásyp: vrstva 1 - šedohnedá až tmavohnedá, vrstva 2 - okrovo žltá s hnedými škvrnami, vrstva 3 - žltohnedá, vrstva 4 - šedohnedá, vrstva 5 - žltohnedá.

Popis: v chate sa nachádzali dve kolové jamky umiestnené v juhozápadnom (priemer $30 \mathrm{~cm}$, híbka $12 \mathrm{~cm}$ ) a juhovýchodnom (priemer $30 \mathrm{~cm}$, híbka $10 \mathrm{~cm}$ ) rohu. V severovýchodnom rohu bola plošinka, možno pre rozpolený kôl a v severozápadnom rohu plošinka pre celý kôl. Kamenné výhrevné zariadenie $(100 \times 120 \times 60 \mathrm{~cm})$ bolo situovanév severovýchodnom rohu. Pozostávalo z plochých kameňov postavených na výšku s rozmermi až $40 \times 30 \mathrm{~cm}$. Zriadenie bolo obsypané drobným kamením. Jeho ústie bolo orientované na juh. Dno bolo reparované červeným 

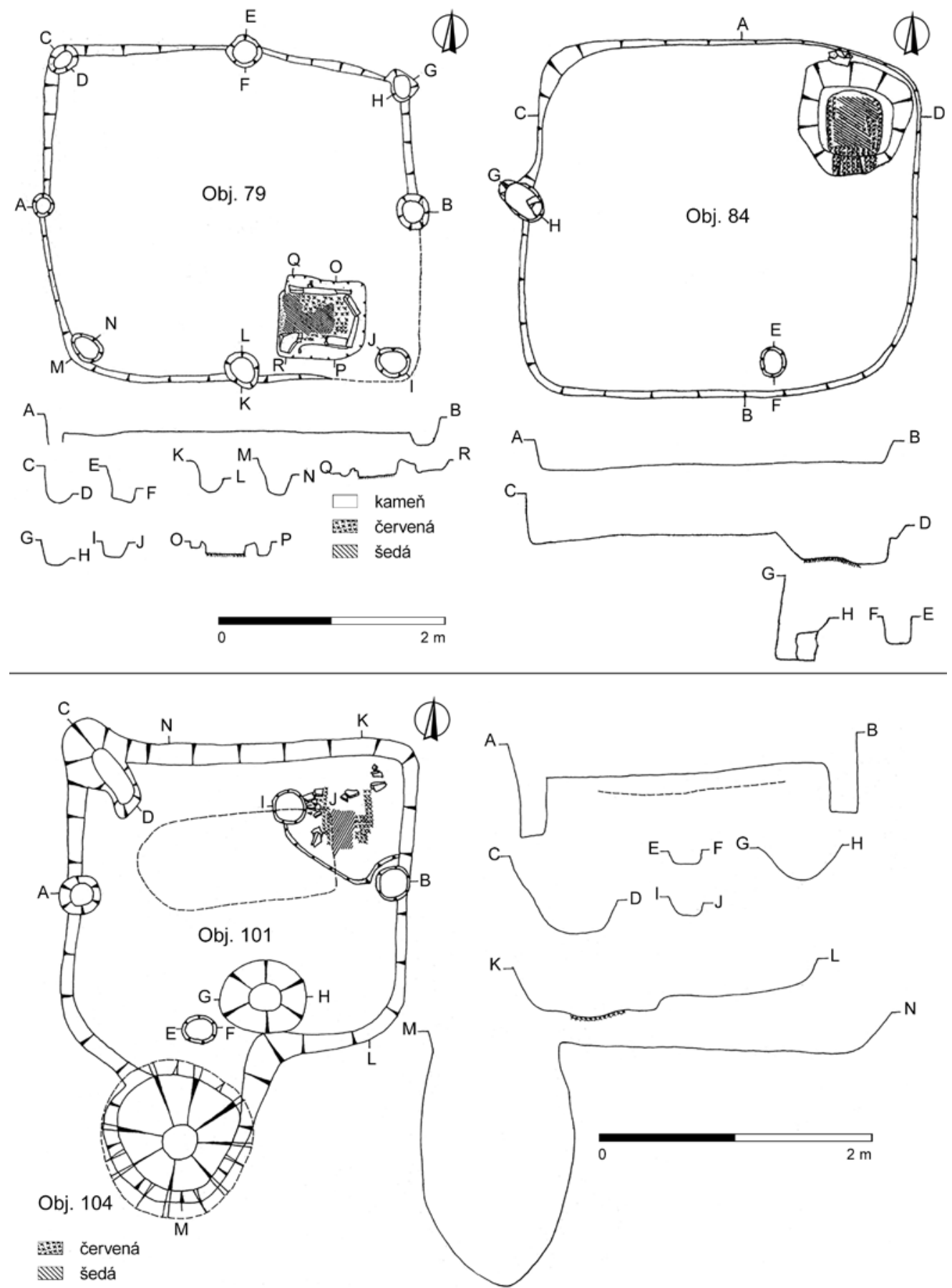

Obr. 3. Objekty 79, 84, 101, 104. Podl'a Geisler 1992, obr. 44, 47, 57. Fig. 3. Features 79, 84, 101, 104. After Geisler 1992, Fig. 44, 47, 57.

prepáleným výmazom hrubým približne $10 \mathrm{~cm}$, naneseným na tmavo hnedú popolovú vrstvu na pôvodnom dne, tvorenom červeným prepáleným podložím. Vo východnej, západnej a snád’ aj severnej stene sú viditel'né plošinky vytvorené na sedenie alebo odkladanie predmetov. Oválny výbežok v juhovýchodnom rohu $(180 \times 80 \mathrm{~cm})$ mohol slúžit ako vstupný koridor. V rámci chaty sa vyskytli aj dve zásobnice (obj. 111 a 113). Vzhl’adom k nelogickej polohe pri krbe môže byt’ obj. 111 starší alebo mladší než chata. Stratigrafické okolnosti v jeho prípade, bohužial', neboli objavené a objekt bol rozpoznaný až na dne chaty. To znemožňuje jeho presnejšie datovanie. Rovnako sa v ňom našlo iba 12 nevel'kých kusov keramiky, čo môže indikovat rýchle zasypanie počas stavby samotnej chaty. Naopak, obj. 113 bol jednoznačne určený ako mladší, vd’aka dobre zaznamenaným profilom výplne chaty, a teda bol v superpozícii s obj. 128. Kumulácia zásobníc, ktorú tvoria obj. 111-113 a 129 naznačuje, že aj obj. 111 ako jej súčast̉ je mladší a vznikol po zániku chaty. Na druhej strane stratigrafia výplne samotnej chaty naznačuje niečo iné. Na jej dne je viditel’ná tenká vrstva 2 , ktorá sa t’ahala nad zásobnicou 111 až $\mathrm{k}$ výhrevnému zariadeniu a zodpovedala by nanesenej a zadupanej vrstve ešte počas využívania chaty. Obsahovala tiež drobné kamienky a kúsky mazanice. Na nej je výrazná vrstva 2 a drobná vrstva 3. Obidve vznikli po opustení chaty cieleným odpadovým zásypom a splavmi okolitých vrstiev (Kuna, Profantová 2005, 120-121). To by naznačoval, že zásobnica 111 bola relatívne staršia. Nie je isté, či vrstvy 4 a 5 tvorili súčasť výplne chaty spolu s vrstvami 1,2 a 3 , alebo boli iba pozostatkami okolitej kultúrnej vrstvy (obr. 4). Nedá sa preto s istotou tvrdit, či okolitá šikmá zníženina z východnej, západnej a južnej strany je súčast’ objektu. Vzhl'adom k tomu, že by podobná šikmá zníženina iba splavovala dažd'ovú vodu rovno do objektu, je to nepravdepodobné. Chata bola zaradená do skupiny 


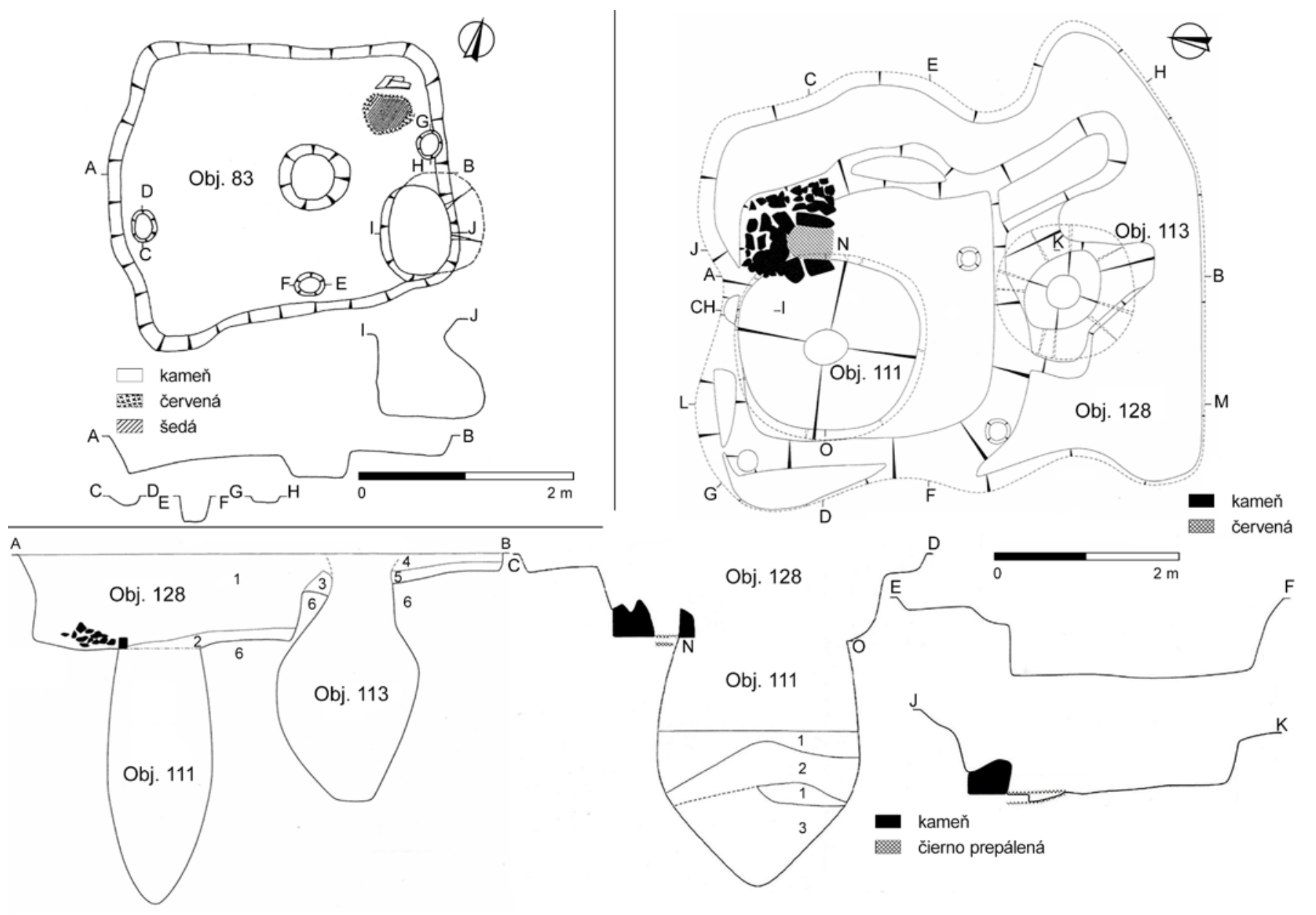

Obr. 4. Objekty 83, 111, 113, 128 a vybrané prierezy. Podl’a Geisler 1992, obr. 46; 2008a, obr. 47-50. Fig. 4. Features 83, 111, 113, 128 and selected sections. After Geisler 1992, Fig. 46; 2008a, Fig. 47-50.

1Ba2 (obr. 4). Objekt bol na základe keramiky datovaný do stredohradištného obdobia (pozri nižšie).

Pôdorysy chát, ktoré boli nájdené na sídlisku nijako nevybočujú zo všeobecných modelov podoby obytných objektov, platných pre strednú aj východnú Európu či severný Balkán v období včasného stredoveku (Vařeka 2004, 307, 312-313, 328-330; Šalkovský 2001, 20-23, 28-29, mapa 1-6). Svojou typológiou a prítomnostou okrúhlych kolových jám zväčša po bokoch objektu, ale ojedinele aj v ňom, indikujú použitie prútených konštrukcií (Dostál 1987, 15-16). Zahĺbené štvorcové stavby s rôznym počtom rôzne rozostavených kolov a s výhrevným zariadením tvorili na lokalite väčšinu obytných objektov. Tieto typy stavieb spolu s inými sú pre vidiecke osídlenie typické u nás a v celom slovanskom svete. Nadzemné stavby sa objavujú až v 8. storočí (Šalkovský 2002, 62-63). Šest̉ chát sa podarilo konkrétnejšie datovat. Tri do strednej doby hradištnej (obj. 19, 84, 128) a tri do starohradištnej doby (obj. 79, 83, 101). Všetky boli zahíbené $\mathrm{s}$ kamenným výhrevným zariadením v rohu, s výnimkou obj. 5, 70 a 83 (obr. 2, 4), kde sa okrem miesta s prepálenou hlinou (zvyšok ohniska) toto zariadenie nepodarilo spol'ahlivo zachytit alebo nebolo nájdené ani ohnisko. Celkovo je zachovalost’ výhrevných zariadení $\mathrm{v}$ chatách $\mathrm{v}$ porovnaní s inými lokalitami vel’mi nízka (Kalčík 2015, 131-134; Marešová 1985, tab. 6-14). Zaujímavý je zvyšok podlahy, obj. 62 (obr. 2). Ten sa nezachoval celý, chýbajú aj kolové jamky. Jeho rozmery v nálezovej správe tiež neboli presne zaznamenané, avšak z digitalizácie kresieb výskumu je vidiet hrany s dížkou približne $2,5 \mathrm{~m}$ a okolo 2 m (druhý koniec ani jednej z hrán nebol objavený, preto je druhý údaj len orientačný), ktoré akoby tvoria čast' obdížnika či štvorca. Na základe toho môžeme predpokladat', že išlo o nadzemnú stavbu snád’ obytného účelu. Pozornosti by nemala uniknút chata, obj. 83 (obr. 3) a 101 (obr. 4), s malou zásobnou jamou $\mathrm{v}$ rohu alebo umiestnenou vedl'a steny.

K otázke typov konštrukcií, tak ako ich definoval B. Dostál (Dostál 1987, 13-17), výskum neposkytol mnoho materiálu. Zachované kolové jamy totiž neumožňujú s istotou rekonštruovat podobu konštrukcií stien, ktoré ohraničovali vnútorný priestor a tvorili často hlavnú oporu strechy. Podl'a rozostupov medzi kolmi je možné uvažovat’ o prútoch vpletených medzi samotné koly alebo o doskách, či menších gul'atinách nabitých horizontálne (v prípade menšej vzdialenosti pozri obj. 79, obr. 3), alebo o vpletených prútoch medzi rad menších kolíkov stojacich v medzerách medzi hlavnými kolmi, pokial' sú medzi nimi väčšie medzery (obj. 5, obr. 3; obj. 101, obr. 4; obj. 83, 128, obr. 5). Fragmenty mazanice (pozri nižšie) však nič okrem pletených konštrukcii nedokladajú. Ostatné chaty majú iba jeden okrajový kôl alebo tieto koly úplne chýbajú. Vrch strechy musel byt približne 3 m od podlahy, aby v zemnici mohol cirkulovat vzduch. Híbka samotného výkopu sa pritom pohybuje v drvivej väčšine prípadov medzi $40-130 \mathrm{~cm}$. Viac než polovica z tejto množiny má híbku od 70-100 cm. Tomu však zodpovedá iba obj. 128 a čiastočne obj. 19 a 84, čo je znakom zlého zachovania výkopov. Samotná híbka vplývala aj na uhol strechy (Šalkovský 2001, 71, 77, 78). Rekonštrukcia strechy nie je možná pri všetkých chatách kvôli často nepríznačnému rozmiestneniu kolových jám. V prípade obj. 58, 79, 101 a 128 predpokladáme sedlovú strechu, 
nakol'ko v nich boli nájdené oproti sebe stojace kolové jamy po oporných koloch. V prípade obj. 70 a 19 sa dá pripustit aj kuželová či pyramídovitá strecha stojaca na centrálnom opornom kole, avšak absencia ostatných kolových jám môže byṫ otázkou zlého zachovania, obzvlášt v prípade obj. 70. Objekty 5 a 83 majú kolové jamy sústredené len na jednej strane, čo dokazuje prítomnost' pultovej strechy, ktorá sa jednou stranou opierala o úroveň vtedajšieho povrchu (Šalkovský 2001, 87-89). Pokusy o rekonštrukciu striech na chatách $\mathrm{v}$ Medlánkach sú značne diskutabilné, nakol'ko nie je možné zaručit kvalitu zachovania všetkých kolových jám. Taktiež štruktúry niektorých chát sú nejednoznačne interpretovatel'né.

Súbor mazanice z lokality Brno-Medlánky (tab. 3, obr. 5) je nepatrný a obsahuje zväčša malé kusy alebo kusy bez viditel'ných odtlačkov stavebnej konštrukcie. Na analýzu nálezov mazanice boli využité vybrané kvality z deskriptívneho systému, ktorého autorom je P. Vařeka (1995, 59-64). Boli to konkrétne kvality ako „materiál“, „výpal“ a „konštrukčný typ“. Materiál bol rozlíšený na málo, stredne a vel’mi kompaktný, podl’a množstva organickej prímesi v hmote. Pri výpale bola mazanica kategorizovaná podl'a tvrdosti a lámavosti ako slabo, stredne, silno a extrémne vypálená (Vařeka 2001, 259-260). Konštrukčné prvky boli rozlíšené podl'a kódovej deskripcie, ktorú vypracovala M. Zavadilová (2011, 110-111). Podrobnejšie rozčlenenie deskripcie, ktorá bola v príspevku použitá, sa však nachádza v jej diplomovej práci na spracovanie mazanice z včasnostredovekej lokality Břeclav-Pohansko (Sotáková 2007, 39-50). Menované kvality sa samozrejme viažu na číslo objektu, kde bol daný kus nájdený. Kompletná databáza nebola z dôvodov nízkeho počtu
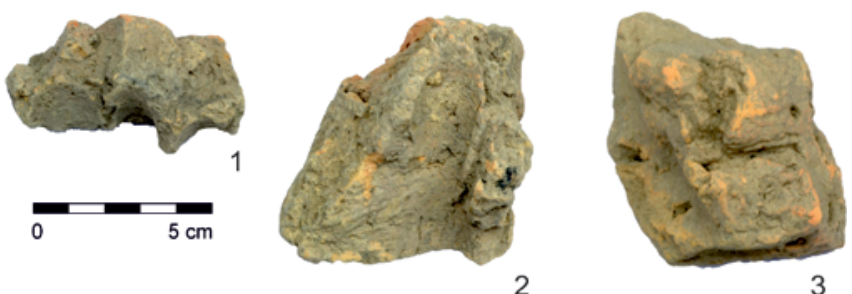

Obr.5. Výber kúskov mazaníc. Foto J. Benech.

Fig. 5. Selection of fragments of daub. Photo by J. Benech.

\begin{tabular}{|c|c|c|c|c|}
\hline č. obj. & Kusy & Materiál & Výpal & Konštrukcia \\
\hline 14 & 1 & stredne kompaktný & silný & F.1.1.2 hrubý povrch na jednej vonkajšej strane \\
\hline 32 & 1 & stredne kompaktný & silný & F.1.1.1 hladký povrch jedna vonkajšia strana \\
\hline 70 & 3 & málo kompaktný & silný & F.1.1.2 hrubý povrch jedna vonkajšia strana \\
\hline \multirow[t]{4}{*}{86} & 3 & vel’mi kompaktný & silný & C.8.1.1 jeden prút bez vonkajšej strany \\
\hline & 1 & vel’mi kompaktný & silný & C.8.2.2 dva prúty, ktoré sa pretínajú, bez vonkajšej strany \\
\hline & 1 & vel'mi kompaktný & silný & F.1.1.1 hladký povrch jedna vonkajšia strana \\
\hline & 1 & stredne kompaktný & stredný & C.1.1.5 prút kolmo na vonkajšiu stranu hladenú \\
\hline 87 & 1 & málo kompaktný & silný & C.5.4.1 na vnútornej strane dva vodorovné prúty a na boku jeden zvisle \\
\hline \multirow[t]{2}{*}{90} & 2 & vel'mi kompaktný & stredný & C.1.1.2 jeden prút a hrubý povrch \\
\hline & 1 & vel'mi kompaktný & stredný & C.8.1.1 jeden prút bez vonkajšej strany \\
\hline \multirow{6}{*}{99} & 1 & stredne kompaktný & silný & C.1.1.2 jeden prút a hrubý povrch \\
\hline & 1 & stredne kompaktný & silný & C.1.2.4 dva prúty, hrubá vonkajšia strana, tvar trojuholníka (špára medzi dvoma prútmi) \\
\hline & 1 & stredne kompaktný & silný & C.8.2.1 dva prúty bez vonkajšej strany \\
\hline & 1 & stredne kompaktný & silný & C.1.3.4 tri prúty a hladený povrch (obr. $5: 1$ ) \\
\hline & 1 & stredne kompaktný & silný & B.4.1.3 obtlačok trámu, vonkajšia a bočná strana hrubá \\
\hline & 1 & stredne kompaktný & silný & D.1.3.2 kombinácia gul'atiny a dvoch rovnobežných prútov na vnútornej strane, povrch hrubý \\
\hline 101 & 1 & vel'mi kompaktný & silný & A.1.2.1 jedna gul'atina (nezachovaný priemer) povrch hladený. \\
\hline 102 & 2 & stredne kompaktný & silný & F.1.1.2 hrubý povrch jedna vonkajšia strana \\
\hline \multirow[t]{2}{*}{17} & 1 & stredne kompaktný & silný & C.1.1.2 jeden prút a hrubý povrch \\
\hline & 1 & stredne kompaktný & silný & C.2.2.1 dva rovnobežné prúty na jednej strane a jeden rovnobežný na druhej, hrubý povrch \\
\hline \multirow[t]{2}{*}{114} & 1 & stredne kompaktný & stredný & C.1.1.5 jeden prút kolmý na vonkajšiu stranu hladenú \\
\hline & 1 & stredne kompaktný & slabý & C.8.2.1 dva prúty bez vonkajšej strany \\
\hline \multirow[t]{2}{*}{130} & 1 & vel'mi kompaktný & slabý & F.1.1.2 bez odtlačku a hrubý povrch \\
\hline & 4 & vel'mi kompaktný & silný & F.1.1.1 bez odtlačku a hladený povrch \\
\hline \multirow[t]{2}{*}{109} & 2 & vel'mi kompaktný & stredný & F.1.1.1 bez odtlačku a hladený povrch \\
\hline & 1 & stredne kompaktný & silný & jedna gul'atina a vedl'a kolmo naň prút bez vonkajšej strany (obr. 5: 3) \\
\hline \multirow[t]{2}{*}{128} & 1 & stredne kompaktný & stredný & F.1.1.1 bez odtlačku a povrch hladený \\
\hline & 2 & slabo kompaktný & stredný & C.1.1.2 jeden prút a hrubý povrch \\
\hline
\end{tabular}




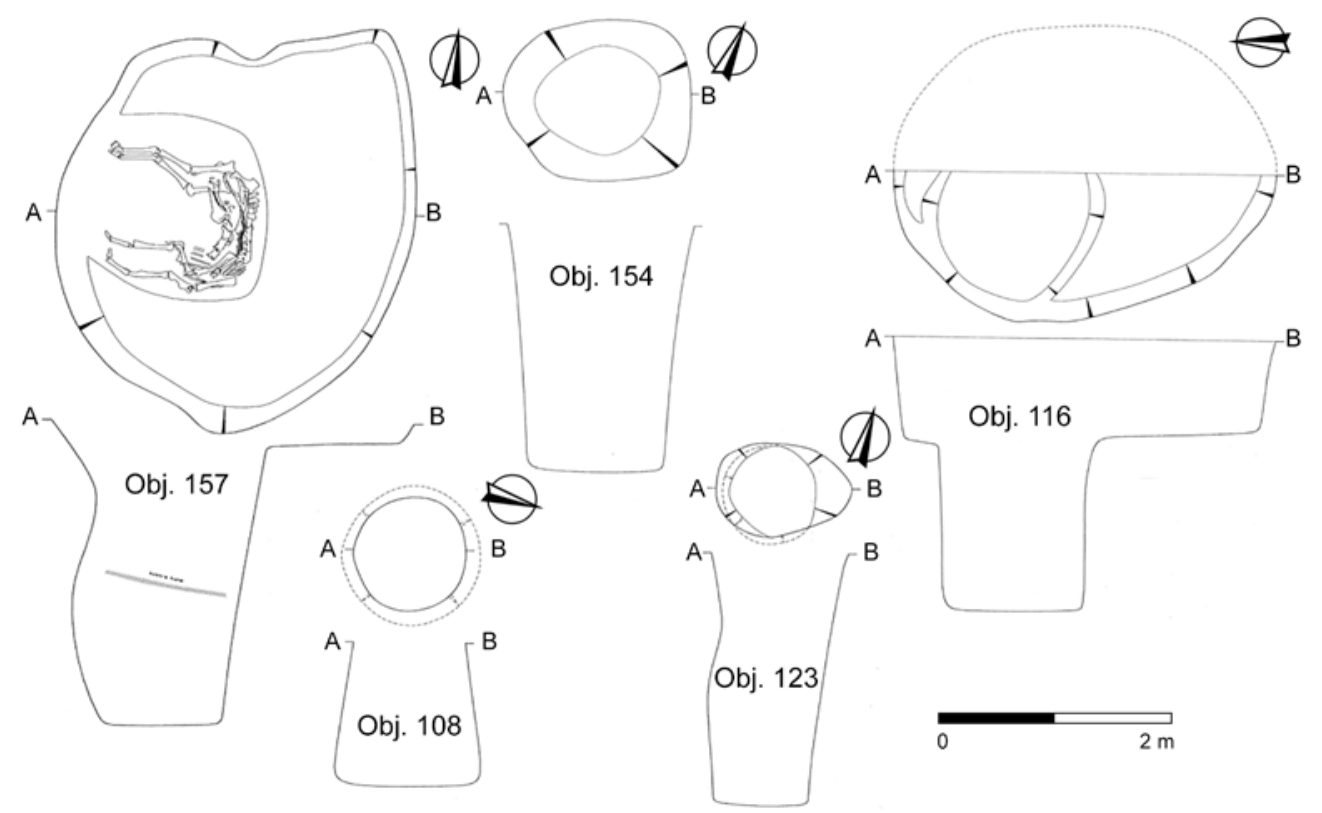

Obr. 6. Výber zásobných jám, objekty 108, 116, 123, 154, 157. Podl'a Geisler 2008a, obr. 7, 8, 11, 12, 27.

Fig. 6. Selection of storage pits, features 108, 116, 123, 154, 157. After Geisler 2008a, Fig. 7, 8, 11, 12, 27.

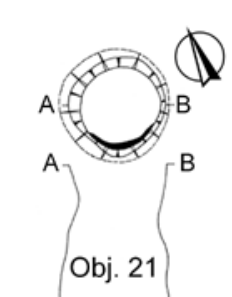

Obj. 21
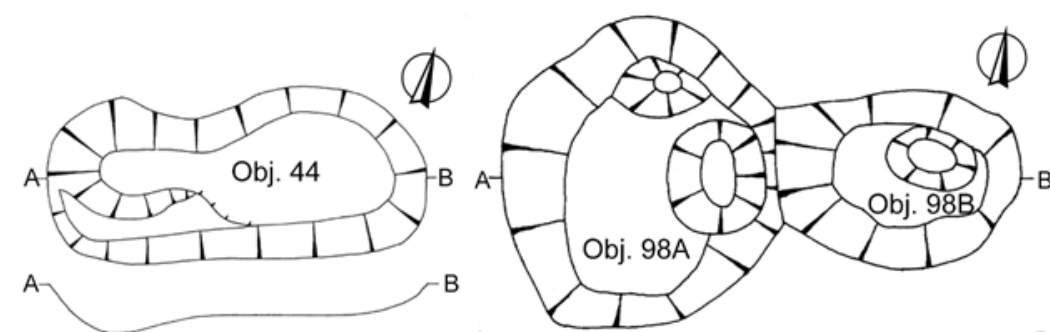

(1)
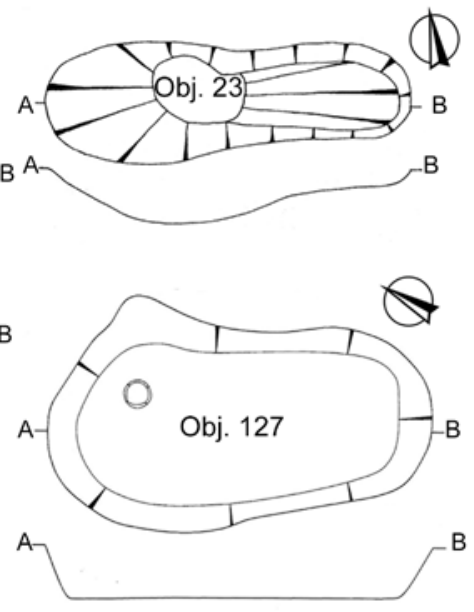

$\Gamma^{B}$
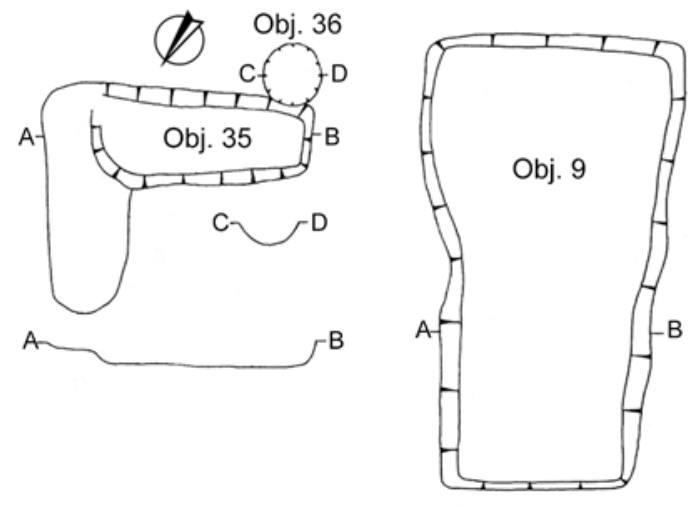

$\theta$
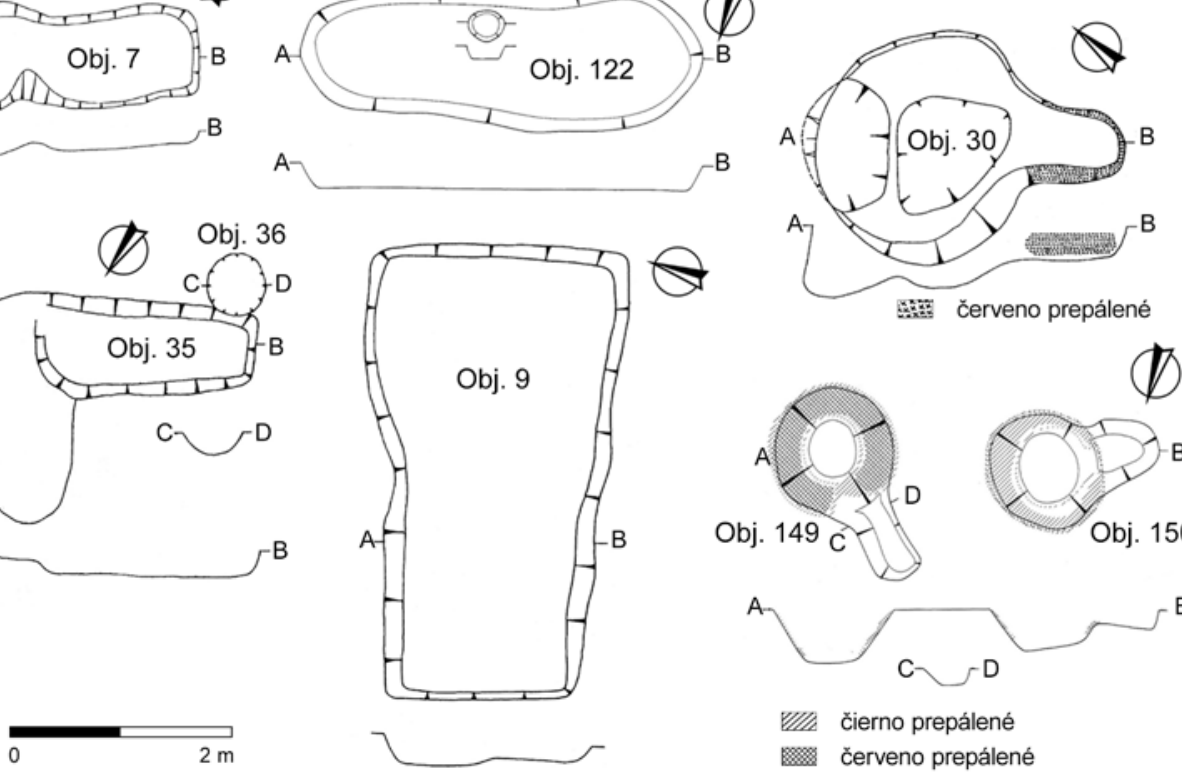
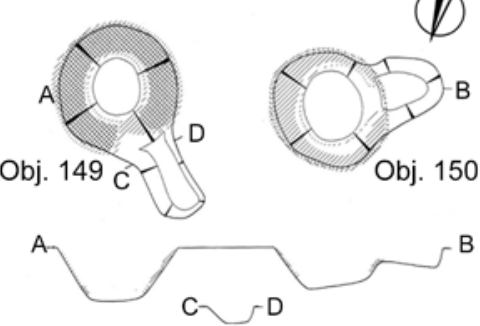

čierno prepálené

čscrveno prepálené
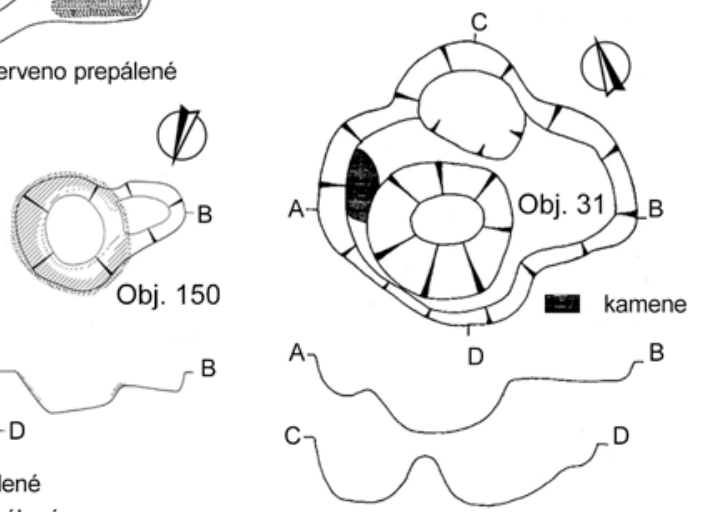

$\Phi$

Obr. 7. Výber sídliskových objektov 7, 9, 21, 23, 30, 31, 35, 36, 44, 98, 122, 127, 149, 150. Podl’a Geisler 1992, obr. 4, 5, 12, 13, 16, 17, 20, 25, 55; 2008a, obr. 20, $21,42$.

Fig.7. Selection of settlement features 7, 9, 21, 23, 30, 31, 35, 36, 44, 98, 122, 127, 149, 150. Geisler 1992, fig. 4, 5, 12, 13, 16, 17, 20, 25, 55; 2008 a, Fig. 20 , 21, 42. 
príslušných nálezov a obmedzenej dokumentácie, v medziach záchranného výskumu zhotovená. Pomocou daných kvalít boli výhradne opísané len tie kusy, ktoré majú k užívaným typom konštrukcie na sídlisku výpovednú hodnotu. Priamo z chát pochádza len minimum kusov. Patrí sem obj. 101, kde jeden kus indikuje prútená konštrukcia a obj. 128 s dvoma kusmi tiež indikujúcimi jednoduchú prútenú konštrukciu. Zrubovú konštrukciu by mohol dokladat iba jeden kus mazanice v obj. 32, ale toto určenie je vel'mi sporné a môže íst' o odtlačok rámu dverí. Zvyšok nálezov z obj. 86 (3ks), 87 (1 ks), 90 (3ks), 99 (8ks) a 114 (3 ks) dokladá prútená konštrukcia (tab. 3). Tento záver podporuje aj typológia chát opísaná vyššie. Vzhl’adom k postdepozičným procesom a malému počtu kusov mazanice $s$ vyššou výpovednou hodnotou nepokladáme za vhodné určovat konštrukčnú podobu konkrétnych objektov. Bude musiet̉ postačit konštatovanie, že na sídlisku prevažovali jednoduché prútené stavebné konštrukcie.

Posledným nálezom s výpovednou hodnotou bol železný klinec z obj. 5 (obr. 31: 3), ktorý ako stavebné kovanie by mohol byt' pozostatkom stavebnej konštrukcie, kde spájal dve drevené časti. K odhaleniu účelu nájdeného klinca poslúžili jeho vel’kost’ a tvar. Klinec zo sídliska v Brne-Medlánkach má typický kladivovitý tvar. Je rovný, dobre zachovaný, s dížkou $6,1 \mathrm{~cm}$. Má štvorhranný prierez. Na prvý pohl'ad pripomína klinec IIIb v typológií R. Krajíca (Krajíc 2003, 65-66, obr. 71) a dokonale zodpovedá sploštenému kladivovitému klincu z Mikulčíc (Klíma 1975, 144-145 obr. 2). Typovo vel'mi podobný klinec bol nájdený na hrade Přerov (Procházka 2017, 244, obr. 79: 5) a takmer identický na včasnostredovekom sídlisku v Mstěnicích (Nekuda 2000, 256, obr. 316: 2). Preto je možné tvrdit, že klinec je včasnostredoveký a nepredstavuje recentný nález.

Ako bolo písané vyššie, na sídlisku bolo preskúmaných 30 včasnostredovekých zásobných jám (obr. 6, 7). Tie sú na rozdiel od prostredia hradísk charakteristické pre vidiecke osady. Primárne slúžili na uskladnenie pol’nohospodárskych produktov. S nadzemnými skladovacími objektmi sa v našom prostredí stretávame len zriedka. Svojim tvarom a rozmermi zásobnice z Medlánok nevybočovali od zásobníc na včasnostredovekých sídliskách (Milo 2014, 106-110). Dvadsat̃ z nich malo typický hruškovitý tvar a zaoblené či ploché dno. Ide o obj. 26, 32, 73, $75,77,86,87,92,93,95,104,106,111-114,129,155,157$ a 159 (obr. 6). Sedem zásobníc malo rovné steny a ploché či zaoblené dno. Ide o obj. 108, 115, 116 (súčast́ pivničnej jamy), 123, 124, 154 a 158 (obr. 7). Zásobnice 18, 28 a 90 mali tzv. kotlovitý tvar. Ivana Pleinerová ich označuje ako typovo najstaršie (Pleinerová 1975, 52-54). Rovnako v ich prípade bolo sledované ploché aj zaoblené dno. Zásobnice obsahovali vel’mi vel’a nálezov, hlavne keramiky, zvieracích kostí a mazanice. V obj. 73, 95 a 106 sa našli zlomky žarnovov, v obj. 86, 112 a 114 sa nachádzali celé žarnovy. V obj. 106 sa okrem zlomkov žarnovov našiel aj sklenený korálik a brúsny kameň. Objekt 113 obsahoval trosku, obj. 129 kostený hrot a obj. 87 zlomok pražnice. Aj napriek tomu, že niektoré zásobnice boli vel'mi bohaté na nálezy keramiky (obj. 32, 92, 93, $104,106,108,113,129)$, podarilo sa presnejšie datovat' iba dve, obj. 92 do starohradištnej doby a obj. 93 do kultúry s keramikou pražského typu. Ďalšie zásobnice, a to 115, 116, 123, 154, 155, 157-159 boli absolútne bez nálezov alebo obsahovali iba jeden kus keramiky, prípadne osteologický materiál. Do raného stredoveku boli zaradené na základe ich hruškovitého tvaru. Najzaujímavejší nález ležal v zásobnici 124, kde bola nájdená kostra človeka (Piačková 2018, 61-62). Priemerná híbka zásobníc na sídlisku dosahovala $215,92 \mathrm{~cm}$. Najhlbšou zásobnou jamou na sídlisku je obj. $157 \mathrm{~s}$ híbkou až $280 \mathrm{~cm}$. V tejto zásobnej jame bol deponovaný celý kôň. Spolu s obj. 116 je aj zásobnicou s najväčším priemerom ústia $340 \mathrm{~cm}$. Priemerný priemer ústia zásobných jám na sídlisku je 161,88cm. Je zaujímavé, že drvivá väčšina zásobných jám bola odokrytá v západnej časti sídliska, čo môže byt spôsobené už spomínaným charakterom odkryvu plochy.

K ostatným objektom na sídlisku sa kvôli malému počtu nálezov a tvarovej asymetrii nemožno vel'mi vyjadrit'. Preto boli dané objekty klasifikované ako sídliskové jamy. Väčšina z nich sa pravdepodobne využívala na získavanie hliny. Na tento účel slúžili okrem vel'kých neforemných jám (obr. 8: obj. 98a, 98b) aj typické plytké korýtkové jamy v tvare obdížnika či oválu, nachádzajúce sa na celom sídlisku (obr. 8: obj. 7, 9, 23, 44). Okrem spomínaných objektov sa na sídlisku vyskytli aj oválne jamy s plochým dnom a jednou kolovou jamkou na okraji, napr. obj. 122 s kolovou jamkou s priemer $30 \mathrm{~cm}$, híbka $10 \mathrm{~cm}$ a obj. 127

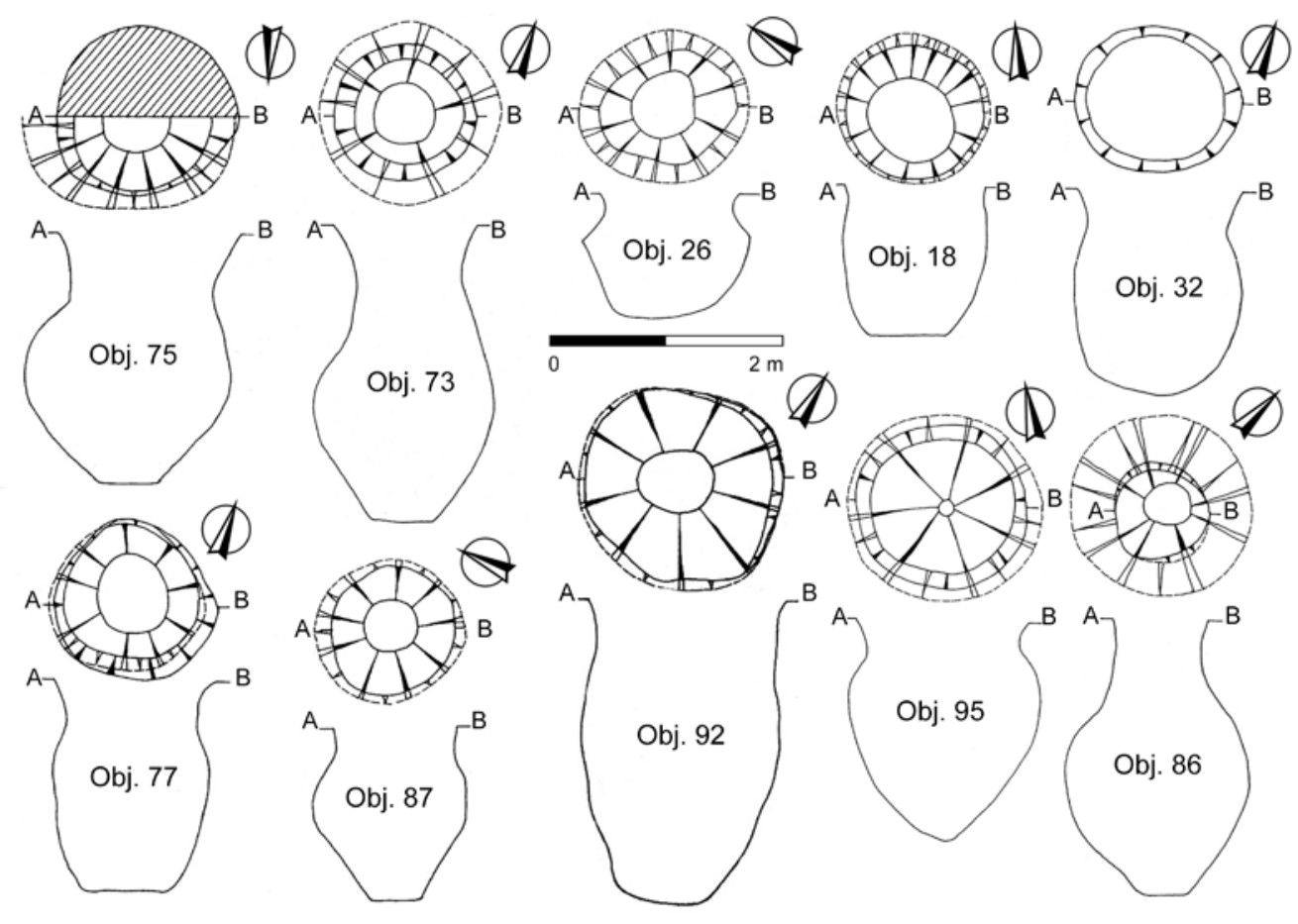

Obr. 8. Výber zásobných jám, objekty 18, 26, 32, 73, 75, 77, 86, 87, 92, 95. Podl'a Geisler 1992, obr. $10,14,18,40$, 42, 43, 48, 49, 51, 52.

Fig. 8. Selection of storage pits, features $18,26,32,73,75,77,86,87$, 92, 95. After Geisler 1992, Fig. 10, 14 $18,40,42,43,48,49,51,52$. 
s jamkou s priemer $25 \mathrm{~cm}$, híbka $8 \mathrm{~cm}$. Obidva sú dlhé približne $3 \mathrm{~m}$ a sú vel'mi chudobné na nálezy (obr. 8: obj. 122, 127). Či mohlo íst’ o menšie prístrešky s uskladňovacím účelom, či prístrešky pre drobné zvieratá, nie je isté. Vzhl'adom k ich vel'kosti je nepravdepodobné, že by išlo o oválne zahĺbené domy, ako ich definoval P. Šalkovský (2001, 42-56). Na sídlisku sa nachádzali aj dve kruhové pece s predpecnými jamami, obj. 149 (priemer $110 \mathrm{~cm}$ a priemer dna $50 \mathrm{~cm}$ ) a 150 (priemer $110 \mathrm{~cm}$ a priemer dna $60 \mathrm{~cm}$ ), vzdialené asi $90 \mathrm{~cm}$ od seba (obr. 8: obj. 149, 150). Mali čiernošedé prepálené steny prechádzajúce na okrajoch $\mathrm{k}$ červenej. Nachádzali sa úplne na severnom okraji sídliska d'alej od obytných objektov. V ich bezprostrednej blízkosti neboli nájdené doklady remeselnej výroby, rovnako sa v nich nenachádzali nijaké nálezy ani kamene. Preto nie je isté, či sú včasnostredoveké. Posledným zaujímavým objektom je obj. 30 . Má nepravidelný kruhový tvar $(232 \times 306$ cm, híbka 68 cm) a nerovné dno. Z juhovýchodnej strany má objekt podkovovitý výbežok s červenou prepálenou vrstvou po celom okraji. Zásyp obsahoval množstvo kameňov (Geisler 1992, 30) a na nálezy nie je bohatý. V obj. 30, ani v objektoch v jeho bezprostrednej blízkosti, sa nijaké doklady výroby nenachádzajú, preto je jeho interpretácia problematická.

\section{Keramický materiál a datovanie}

Keramika tvorila na lokalite najpočetnejší nálezový súbor a svojou rozmanitou skladbou chronologicky pokryla obdobie od kultúry s keramikou pražského typu až po strednú dobu hradištnú. Väčšinu objektov, vzhl'adom k nedostačujúcim keramickým súborom, nebolo možné presnejšie datovat'. Neumožňovala to prítomnost' výrazných kusov či prevaha niektorého z horizontov. Svoj podiel na tom majú postdepozičné procesy, ktoré sa za stáročia postarali o fragmentarizáciu, zánik a sekundárny až terciálny transport keramických jedincov, vd’aka ktorým je datovanie problematické. Zároveň sa z novšieho materiálu, dôsledkom už spomínanej povodne, stratila všetka keramika z obj. 151, 152, 154-159, preto ich datovanie do doby hradištnej je založené na informáciách z nálezovej správy (Geisler 2008a, 4-6).

Na základe nálezov keramiky z Brna-Medlánok a štúdií J. Macháčka (Macháček 2000, 26-32; 2001, 207-218) bola vytvorená relatívna chronológia, pokrývajúca celé trvanie sídliska. Na základe nej, ak to bolo možné, boli datované sídliskové objekty. Kresby materiálu z výskumu v roku 1984 boli vyhotovené v rámci nálezovej správy (Geisler 1992, obr. 65-134). Z týchto upravených kresieb boli vytvorené tabul'ky keramiky.

Patričnú pozornost̉ keramickému materiálu z Brna-Medlánok venuje D. Zapletalová (2001, 125-135) vo svojej diplomovej práci. Opisuje jeho výzdobu a tvarovú variabilitu, porovnáva ho s dovtedy platnými modelmi datovania a zvláštny dôraz kladie na častý výskyt prímesi sl’udy v materiáli. V práci upozornila na charakteristické rysy tohto keramického súboru, ktoré boli v analýze podrobnejšie overené (pozri nižšie). Na jeho základe vytvorila predbežný model datovania. Počiatok sídliska datovala do obdobia kultúry s keramikou pražského typu. Spomína tiež prítomnost tzv. zdobeného pražského typu, avšak ten nebol v materiáli zachytený. Keramiku starohradištného obdobia delí podrobnejšie, hlavne podl’a rýchlosti rotácie nádoby pri jej výrobe. Osídlenie tu podl’a nej pretrvávalo až do konca 9. storočia. To naznačuje vel'ký výskyt keramiky s pravidelnou výzdobou, aj prítomnost výzdoby rytej jednozubým nástrojom. Upozorňuje tiež na výskyt derivátov blučinského výrobného

\begin{tabular}{|c|c|c|c|}
\hline \multicolumn{4}{|l|}{ Výzdoba } \\
\hline hreb. pás & A1 & hreb. pásy vedl'a seba & A2 \\
\hline hreb. pásy cez seba & A3 & hreb. vlnovka & $\mathrm{B} 1$ \\
\hline hreb. vlnovky vedl'a seba & $\mathrm{B} 2$ & hreb. vlnovky cez seba & B3 \\
\hline hreb. vlnovka medzi hreb. pásmi & $\mathrm{C} 1$ & hreb. vlnovky medzi hreb. pásmi & $\mathrm{C} 2$ \\
\hline hreb. pásy medzi hreb. vlnovkami & $\mathrm{C} 3$ & hreb. vlnovka nad hreb. pásmi & $\mathrm{C} 4$ \\
\hline hreb. pásy nad hreb. vlnovkami & C5 & kombinácia hreb. vlnoviek a hreb. pásov & C6 \\
\hline hreb. vlnovky a hreb. pásy cez seba & $\mathrm{C} 7$ & ryha & D1 \\
\hline ryhy & D2 & ryhy cez seba & D3 \\
\hline vlnovka & E1 & vlnovky & E2 \\
\hline vlnovky cez seba & E3 & vlnovka nad ryhami & F1 \\
\hline vlnovky nad ryhami & $\mathrm{F} 2$ & vlnovky medzi ryhami & F3 \\
\hline kombinácia vlnoviek a rýh & F4 & blučinský motív & F5 \\
\hline vlnovky cez seba s ryhami & F6 & ryhy cez seba s vlnovkami & F7 \\
\hline vlnovky a ryhy cez seba & F8 & hreb. ornament s ryhami či vlnovkami & G \\
\hline hreb. vpichy & H1 & záseky & $\mathrm{H} 2$ \\
\hline vpichy jednozubým nástrojom & $\mathrm{H} 3$ & hreb. vpichy s hreb. vlnovkami a pásmi & I1 \\
\hline hreb. vpichy s ryhami a vlnovkami & $\mathrm{I} 2$ & záseky s ryhami & $\mathrm{I} 3$ \\
\hline záseky s ryhami a vlnovkami & I4 & záseky s vlnovkami & I5 \\
\hline záseky s hreb. vlnovkami a pásmi & I6 & vpichy jednozub. nástrojom s ryhami či vlnovkami & I7 \\
\hline vpichy jednozub. nástrojom s hreb. vlnovkami či pásmi & I8 & iné motívy & $\mathrm{J}$ \\
\hline \multicolumn{4}{|l|}{ Okraj } \\
\hline zaoblený & A1 & zaoblený zužujúci sa & $\mathrm{A} 2$ \\
\hline zrez. kuž. a valc. jednoduché & $\mathrm{B} 1$ & zrez. kuž. a valc. vytiahnutá spodná hrana & B2 \\
\hline zrez. kuž. a valc. vytiahnutá horná hrana & B3 & zrez. kuž. a valc. vytiahnutá spod. aj hor. hrana & B4 \\
\hline zrez. nálevkovité jednoduché & $\mathrm{C} 1$ & zrez. nálev. vytiahnutá spod. hrana & $\mathrm{C} 2$ \\
\hline zrez. nálev. vytiahnutá hor. hrana & $\mathrm{C} 3$ & zrez. nálev. vytiahnutá spod. aj hor. hrana & $\mathrm{C} 4$ \\
\hline zrez. vod. jednoduché & D1 & zrez. vod. vytiahnutá vonkajšia hrana & $\mathrm{D} 2$ \\
\hline zrez. vod. vytiahnutá vnútorná hrana & D3 & zrez. vod. vytiahnutá von. aj vn. hrana & D4 \\
\hline kolmo prežl’abený & E1 & šikmo prežl’abený & E2 \\
\hline zašpicatené & $\mathrm{F}$ & zosilnené a bohato profilované & G1 \\
\hline zosilnené a zrezané & G2 & vyhnuté a vytiahnuté & $\mathrm{H}$ \\
\hline iné & I & & \\
\hline
\end{tabular}

Tab. 4. Zoznam kódov okrajov a výzdoby. Podl’a Macháček 2001, 49-50, obr. 3, 4.

Tab. 4. List of codes for types of rims and decorations. According to Macháček 2001, 49-50, Fig. 3, 4. 
okruhu a jemnej rýchlo obtáčanej keramiky. Nakoniec spomína možný výskyt mladohradištných jedincov, ale ich prítomnost’ bola po spracovaní materiálu vylúčená. Na tvorbu chronológie použila D. Zapletalová empirickú metódu, svoje závery teda formulovala na základe autopsie. Tie boli, ako sama uvádza, predbežné a v mnohých ohl'adoch otvorené a diskutabilné (Zapletalová 2001, 125-135).

Vzhl'adom na malý počet jedincov v jednotlivých objektoch a mieru intrúzie by bolo aplikovanie štatistických metód neadekvátne a nepresné, preto v tejto analýze neboli použité. Nakol'ko šlo o záchranný výskum, nemôžeme vylúčit istú mieru úmyselnej či neúmyselnej skartácie. Tieto skutočnosti tiež zabránili sledovat mieru fragmentarizácie materiálu štatisticky. Určovanie keramiky ako primárneho, sekundárneho či terciálneho odpadu bolo kvôli nezachyteniu vrstiev či presnejšej polohy keramických nálezov značne problematické. Zvyšok objektov bol datovaný na základe pomeru zastúpených keramických horizontov a prítomnosti signifikantných kusov. Relatívna chronológia, ktorá bola nakoniec vypracovaná, pozostáva z troch horizontov: RS1 (kultúra s keramikou pražského typu), RS2 (starohradištné obdobie) a RS3 (stredohradištné obdobie). Vel'mi bohaté zastúpenie keramiky starohradištného obdobia umožnilo rozdelit horizont RS2 na dve fázy. Skratka RS pochádza z českého slova „raný středověk“. V slovenskom jazyku by mala mat podobu VS,

obj. 90
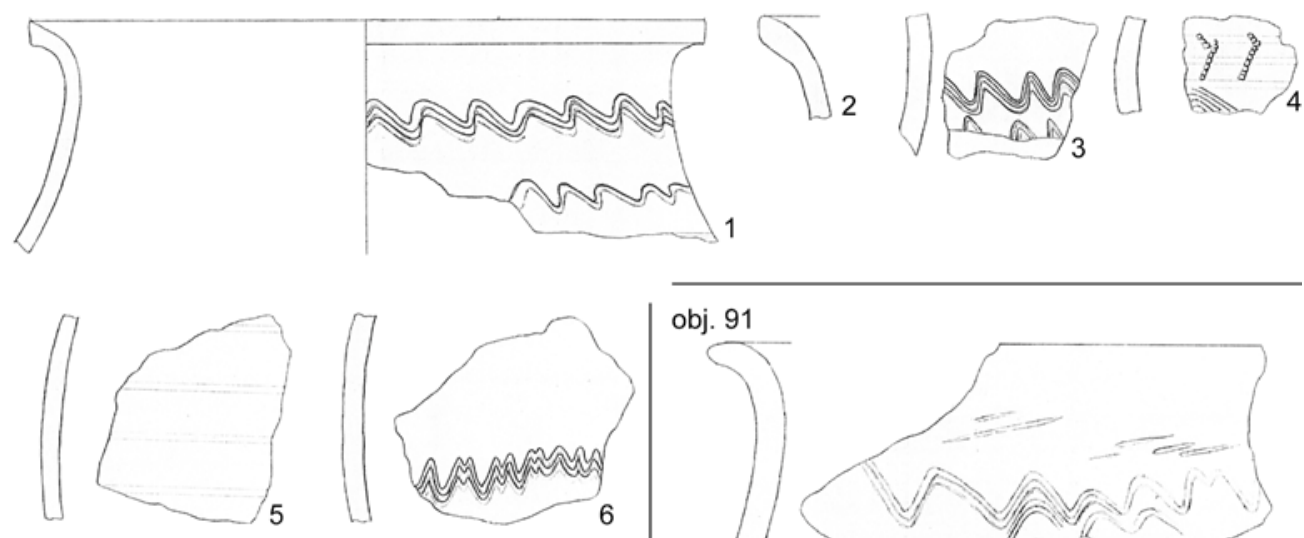

obj. 91

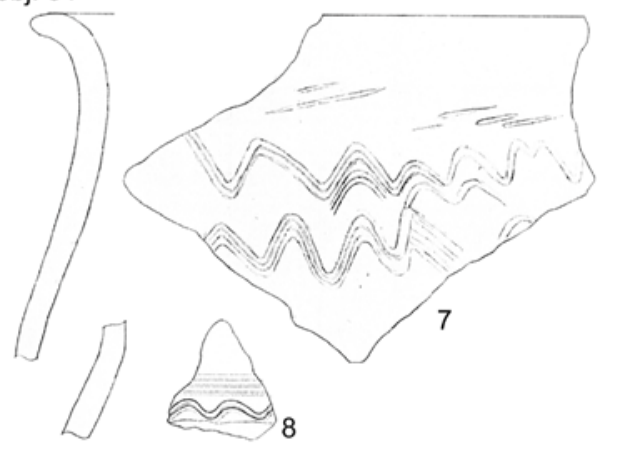

obj. 92
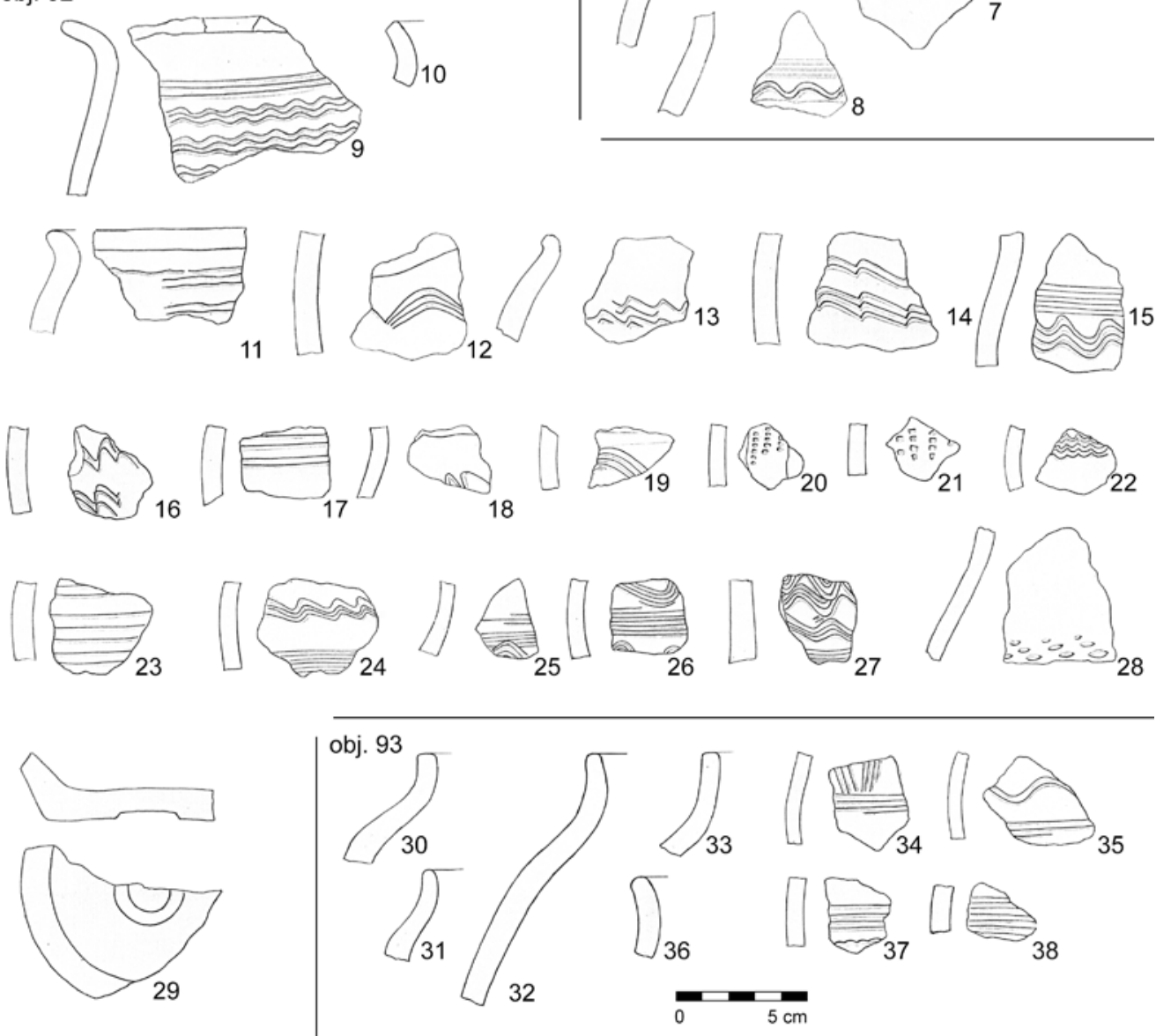

Obr. 9. Výber keramiky z objektov 90-93. Podl'a Geisler 1992, obr. 116-121.

Fig. 9. Selection of pottery from features 90-93. After Geisler 1992, Fig. 116-121. 
teda „Včasný stredovek“. Skratka VS však už v českom archeologickom prostredí, kde je publikovaný aj tento článok, existuje a znamená „vrcholný středověk“. Z toho dôvodu bol aj napriek jazyku príspevku použitý český variant RS. Všetky aplikované kódy výzdoby a okrajov v tejto kapitole sú vysvetlené v prehl'adnej tabul'ke (tab. 4). Základ chronológie bol vypracovaný pomocou kritérií v už spomínaných prácach J. Macháčka (Macháček 2000, 26-32; 2001, 207-218). Kódy kvality materiálu majú nasledovný význam: I(HDV) - hrubá dobre vypálená, I(HZV) - hrubá zle vypálená, I(super HDV) - super hrubá dobre vypálená, I(super HZV) - super hrubá zle vypálená, II(JDV) jemná dobre vypálená, II(JZV) - jemná zle vypálená.

\subsection{RS1 - kultúra s keramikou pražského typu (550-650)}

Typickú náplň predstavuje ručne modelovaná keramika s ostrou piesčitou prímesou. Materiál je super hrubý zle vypálený, ojedinele dobre vypálený. Tvar je nepravidelný a neobsahuje výzdobu. Okraje sú zaoblené, zväčša zvislé alebo len mierne prehnuté, v podstate nevýrazné. Na lokalite sa v porovnaní s ostatnými horizontmi našlo len pár kusov prevažne vydutín, ale nájdené boli aj okraje (obr. 9: 30-33), ktoré zodpovedali skupine B, keramiky pražského typu (d’alej KPT) podl’a D. Jelínkovej (1990, 254- 255, obr. 2). Opisovaný súbor pozostával výlučne zo zlomkov.

Keramika horizontu RS1 sa nachádzala v objektoch 18, 27, 76, 93 a 94. V obj. 93 (Geisler 1992, obr. 120, 121) však, aj vzhl’adom obj. 68
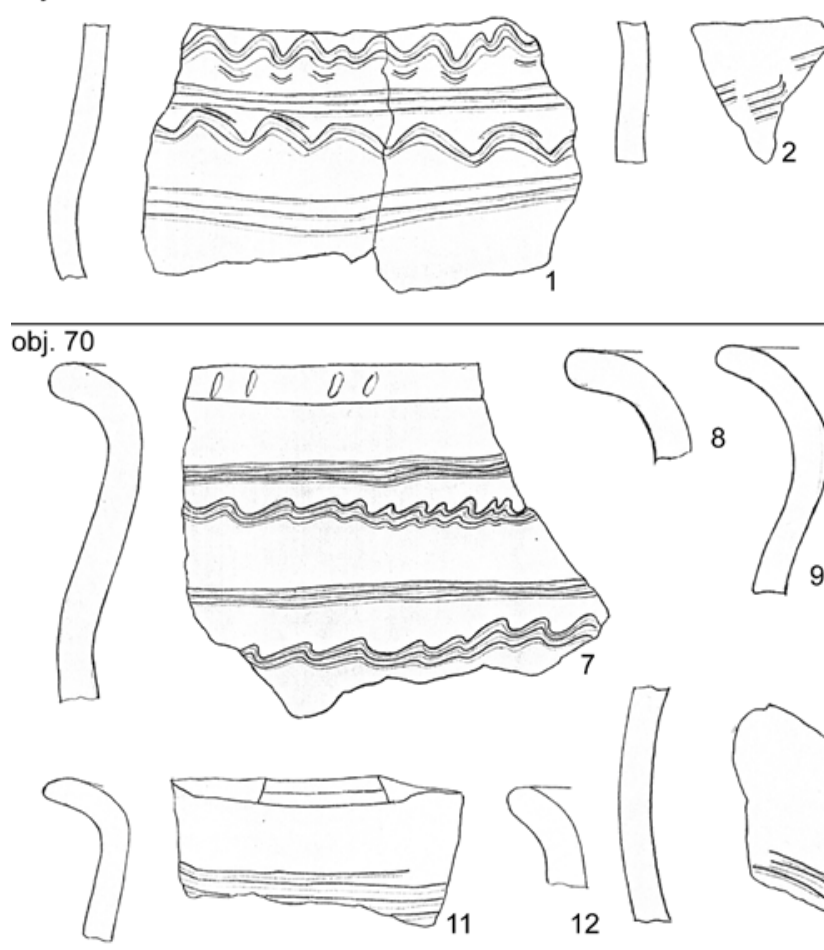

8

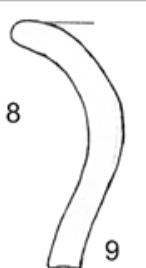

obj. 69
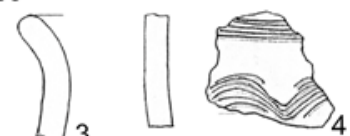

obj. 71
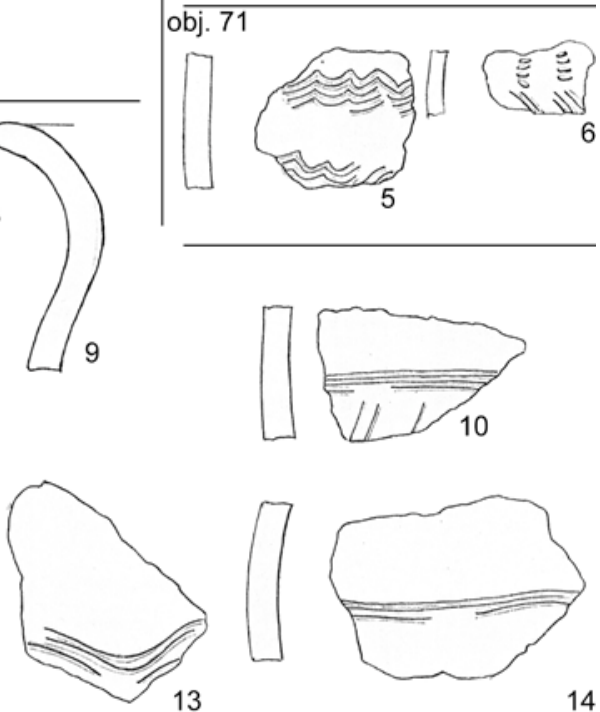

13
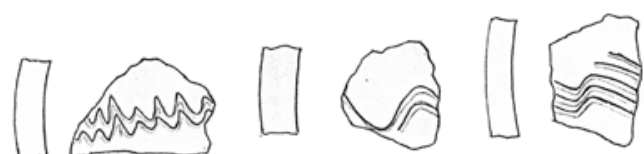

17
18

19

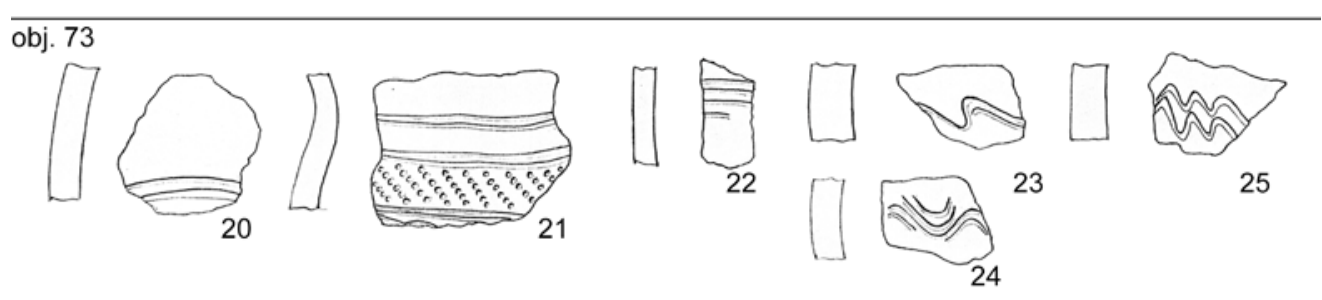

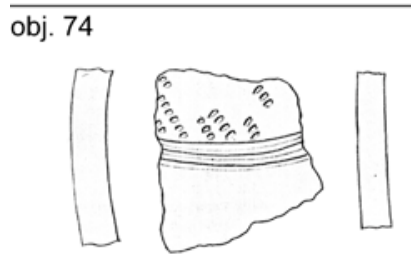

26

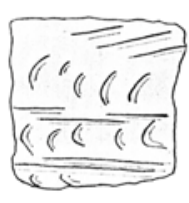

27
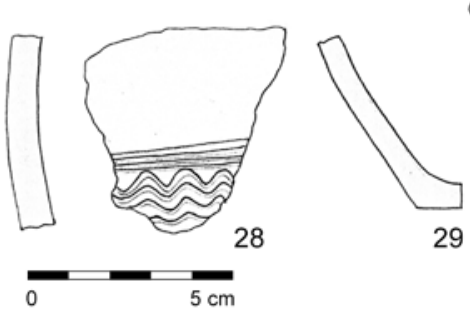

29
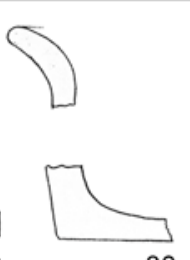

30
Obr. 10 Výber keramiky z objektov 68-71, 73, 74. Podl’a Geisler 1992, obr. 106-108.

Fig. 10. Selection of pottery from features 68-71, 73, 74. After Geisler 1992, Fig. 106-108. 
k malému počtu nálezov, výrazne prevažovala nad nálezmi ostatných horizontov. Podl’a nálezovej správy sa v objekte nachádzalo spolu 28 kusov keramiky (Geisler 1992, 92-93; obr. 120, 121), z toho 20 kusov bola hrubá keramika KPT. Tento súbor obsahoval aj tri hrubé kusy dna a okrajov, ktoré sa podl'a chronológie D. Jelínkovej (Jelínková 1990, 254-255, obr. 2) radia do skupiny B KPT (obr. 9: 30-33). Tieto dná aj okraje sú v súčasnej dobe stratené, rovnako ako tri kusy hrubých vydutín. Taktiež bol prítomný črep patriaci do prvej fázy horizontu RS2 (obr. 9: 34) a jeden črep nedatovaný. Objekt obsahoval aj iné kusy, ktoré sú takisto stratené, teda nie sú v databáze a nemohli byt’ nijak kvantifikované. V súbore chýbajú aj štyri mladšie črepy s rytou výzdobou a dva mladšie zaoblené okraje. Mladšie kusy sa tam objavili asi vplyvom postdepozičného pohybu. Výrazná prítomnost' keramiky skupiny B robí z obj. 93 najstarší objekt na lokalite a rámcovo ho datuje, spolu so vznikom sídliska, do druhej polovice 6. až prvej polovice 7. storočia. Spomínané okraje sú stratené a nie sú v databáze. To neumožňuje vytvorit kvantifikačnú tabul'ku pre tento horizont.

\subsection{RS2 - starohradištné obdobie (650-800)}

Prvá fáza zahŕňa keramiku s primitívnou a nepravidelnou výzdobou pozostávajúcou $\mathrm{z}$ atypických hrebeňových, ale hlavne rytých vzorov, ako sú napr. zvislé krátke zväzky rýh, pol kruhy

obj. 108
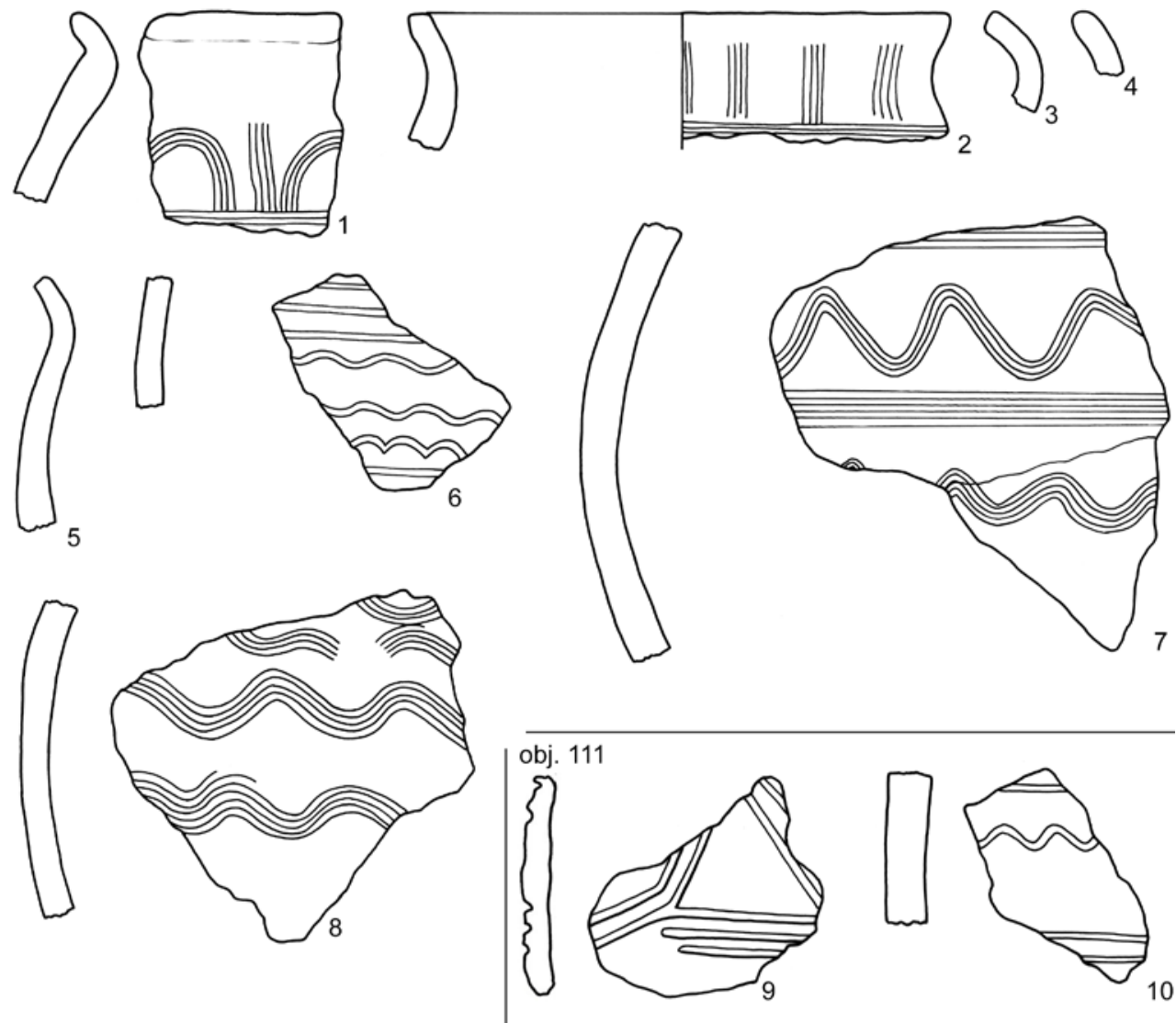

obj. 112

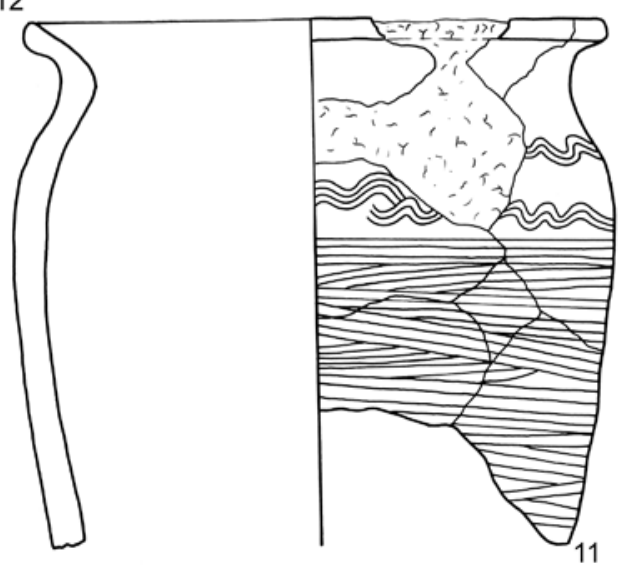

obj. 118
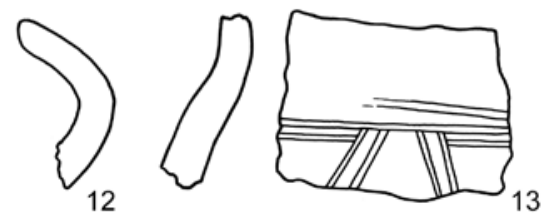

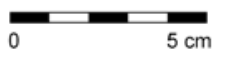

Obr. 11. Výber keramiky z objektov 108, 111, 112, 118. Kresba J. Benech. Fig. 11. Selection of pottery from features 108, 111, 112, 118. Drawing by J. Benech. 
alebo trojuholníky (obr. 9: 34; 10: 10; 11: 1, 2, 9, 13). Obtáčanie nádob je slabo formujúce alebo žiadne, profilácia je jednoduchá, okraje sú málo vyhnuté, previsnuté, pri zdobení nádoba stojí. Majú zaoblené ukončenie. Na lokalite bola produkcia tejto fázy zastúpená vel’mi nevýrazne, nepodarilo sa do nej zaradit žiaden objekt. Nálezy z nej boli takmer rovnako nepočetné, ako keramika pražského typu. Nachádzali sa v rôznych objektoch (obj. 70, 93, 108, 111, 118), avšak nikde netvorili výraznejší súbor.

$\mathrm{V}$ druhej fáze výzdoba pozostáva $\mathrm{z}$ hrebeňových vlnoviek, pásov aj vodorovných rýh. Hrebeňové vlnovky sú rutinné, nízke, sklonené väčšinou medzi pásmi, ojedinele sa vyskytujú zahrotené vlnovky a hrubšie rytie (obr. 9: 7, 9; 12: 4; 13: 22;
14: 4, 14; 15: 3; 16:23, 24; 17: 1). Objavujú sa hrebeňové vpichy (obr. $14: 10-13 ; 15: 1 ; 18: 28 ; 19: 13 ; 20: 18 ; 10: 21 ; 17: 48$ ) a odtlačky (obr. 12: 21; 19: 16; 21: 4; 22: 19). Pri zdobení nádoba pomaly rotuje, viditel'ný je výraznejší výskyt hrebeňovitej rytej výzdoby. Okraje sú obtáčanejšie a viac vyhnuté, ale stále previsnuté alebo vytiahnuté. Sú zaoblené, prípadne zaoblené zúžené alebo prosté kužel'ovito zrezané, môžu byť ojedinele aj zdobené. Začína sa objavovat jemný materiál. Táto fáza tvorila vel'kú čast' keramického materiálu na sídlisku.

Do druhej fáze bolo možné datovat ovel'a viac objektov. Umožňovalo to množstvo starohradištných keramických nálezov, ktoré početne prevažovali nad ostatnými horizontmi,

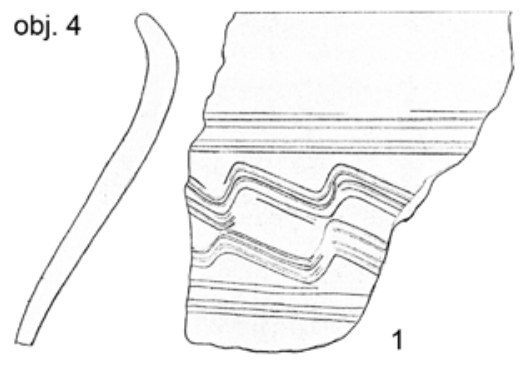

obj. 5
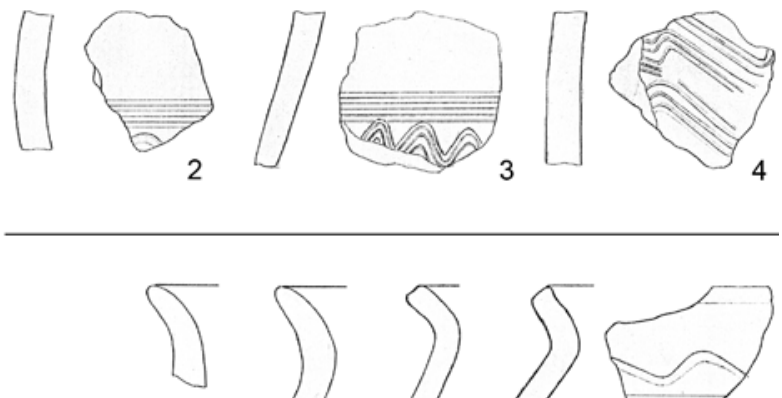

5

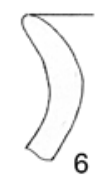

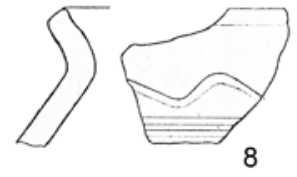
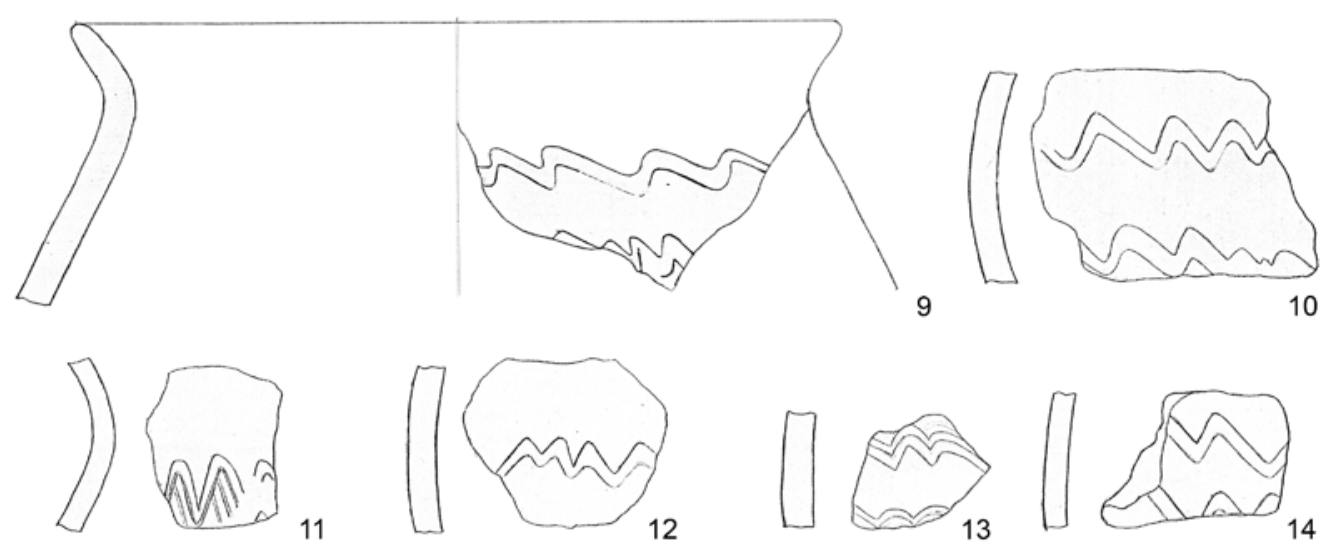

obj. 10
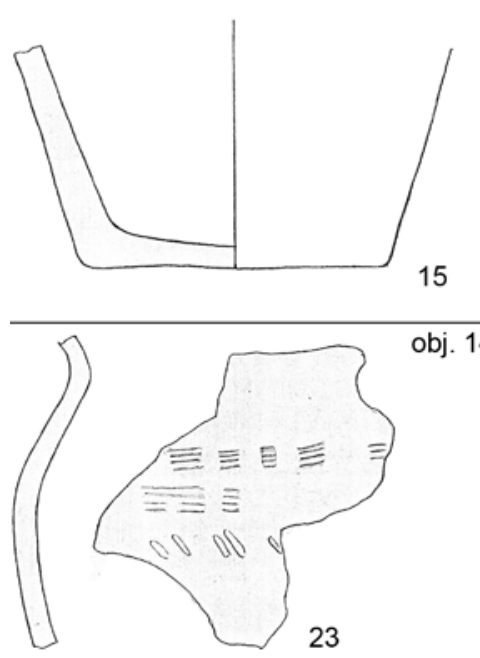

23

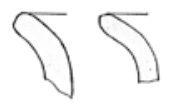

16
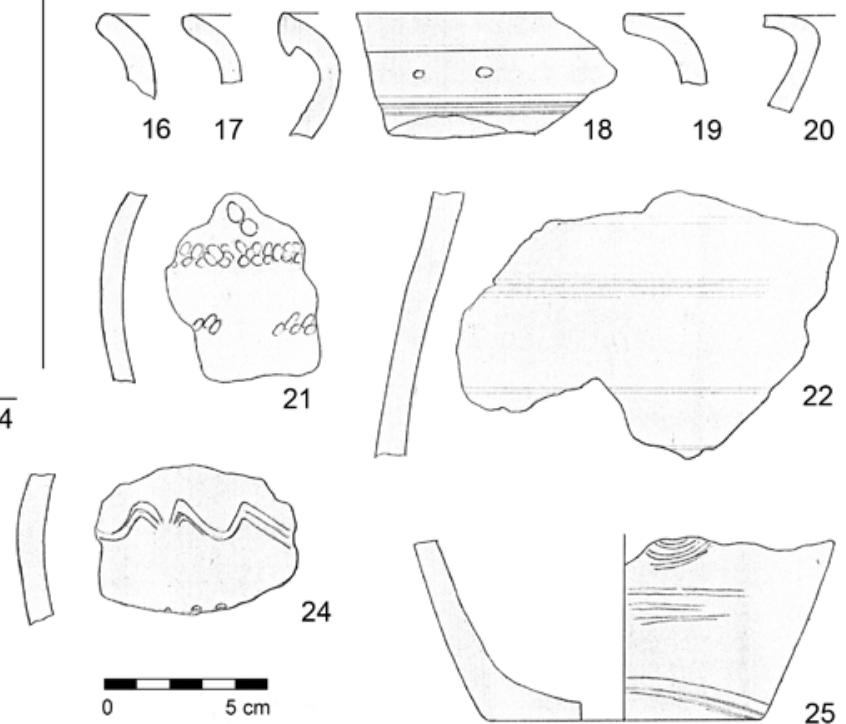

24

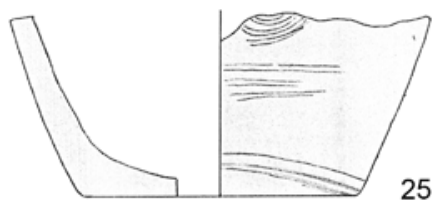

Obr. 12. Výber keramiky z objektov 4, 5, 10, 14. Podl'a Geisler 1992 , obr. 65-67, 74, 75.

Fig. 12. Selection of pottery from features 4, 5, 10, 14. After Geisler 1992, Fig. 65-67, 74, 75. 
avšak relatívne spol’ahlivé datovanie do tejto fázy RS2(2) bolo možné len u deviatich objektov, a to obj. 7 (obr. 10), 21 (obr. 13), 24 (obr. 14), 79 (obr. 22), 83 (obr. 16), 92 (obr. 9), 101 (obr. 23), 104 (obr. 23, 24) a obj. 130 (obr. 25). Tento stav je zapríćinený na jednej strane faktom, že fáza neposkytla dostatočný počet výrazných kusov a skutočnostou, že vzhl'adom ku konzervatívnemu prístupu k výzdobe a spôsobu výroby je mnoho črepov s nekompletnou výzdobou alebo nevýrazným okrajom možné datovat nielen do horizontu RS2, ale aj do RS3. Na kvantifikačných tabul'kách (tab. 5-8) boli sledované jednotlivé atribúty, ktoré umožnili objekty datovat'. Na konci tabuliek 5 a 9 (níže) je uvedený celkový počet jedincov v objekte.
Obtáčaná slabo formujúca keramika viditel’ne prevažuje vo všetkých objektoch. Tomu zodpovedá aj materiál, ktorý je z väčšiny hrubý zle vypálený. Hrubý dobre vypálený materiál tiež nie je pre druhú fázu horizontu RS2 nezvyklý, aj ked' sa objavil len v malom množstve. Iné druhy materiálu sú zastúpené minimálne. Starohradištná výzdoba, reprezentovaná hrebeňovými vlnovkami, pásmi, vpichmi a ich kombináciami (A1-C6 a H1-H4 a I1), taktiež prevažuje vo všetkých objektoch. V mnohých prípadoch sa tieto typy výzdoby dajú datovat aj do horizontu RS3, čo môže datovanie skomplikovat'. Zaujímavú mladšiu intrúziu tvorí pokročilý okraj s rytou vlnovkou na hrdle v obj. 79. Je to asi zlomok nádoby blučinského výrobného okruhu či jeho

obj. 7
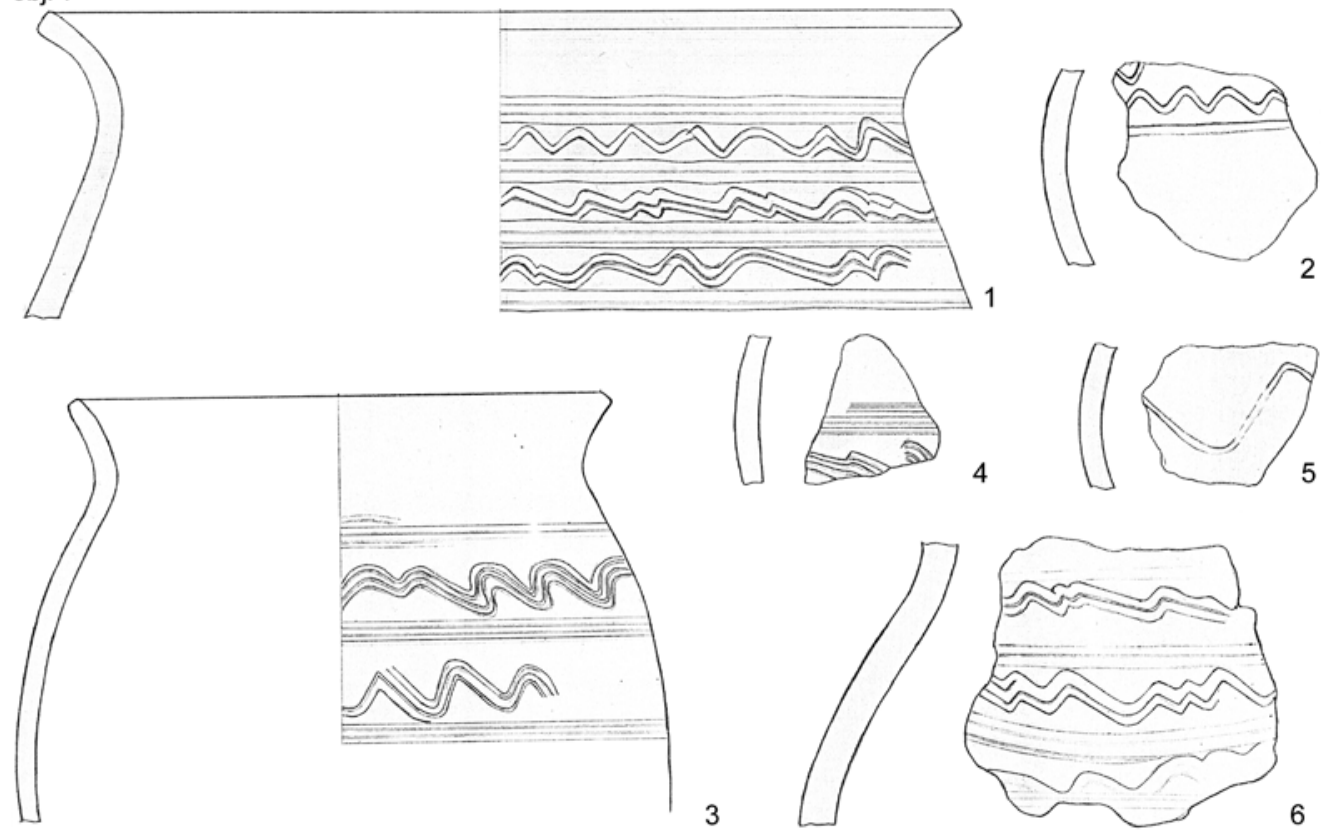

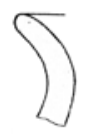

7
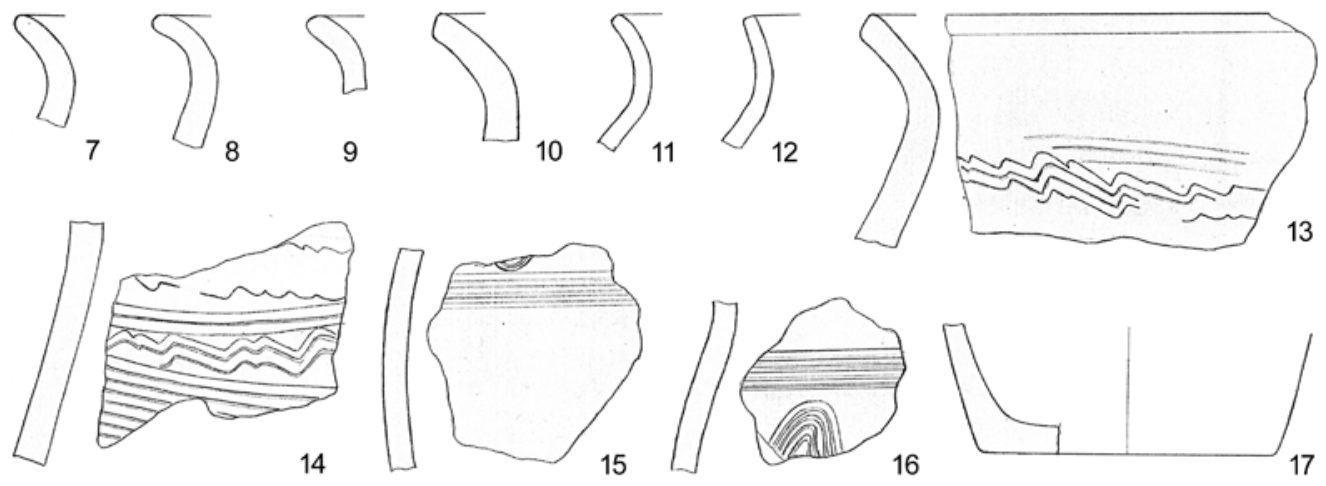
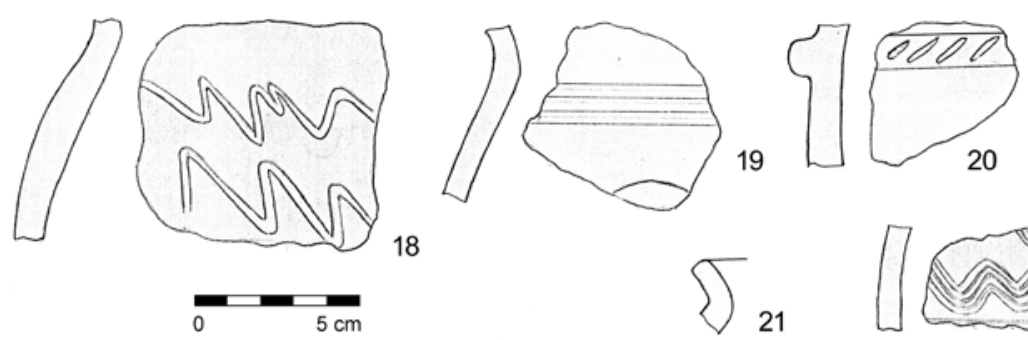

obj. 20

obj. 18
8

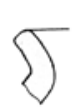

21

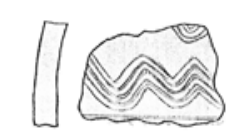

22

2 ,

. 


\begin{tabular}{lrrrrr}
\hline Technológia & Nesledované & $\begin{array}{r}\text { Obtáčanie silno } \\
\text { formujúce }\end{array}$ & $\begin{array}{r}\text { Obtáčanie slabo } \\
\text { formujúce }\end{array}$ & V ruke & $\begin{array}{r}\text { Počet } \\
\text { jedincov }\end{array}$ \\
\hline obj. 7 & 5 & 2 & 25 & 2 & 34 \\
\hline obj. 21 & 11 & 0 & 16 & 0 & 27 \\
\hline obj. 24 & 9 & 2 & 14 & 1 & 26 \\
\hline obj. 79 & 15 & 1 & 28 & 0 & 45 \\
\hline obj. 83 & 15 & 6 & 12 & 0 & 33 \\
\hline obj. 92 & 16 & 1 & 10 & 0 & 27 \\
\hline obj. 101 & 16 & 1 & 25 & 2 & 44 \\
\hline obj. 104 & 21 & 0 & 14 & 2 & 37 \\
\hline obj. 130 & 10 & 0 & 29 & 0 & 39 \\
\hline
\end{tabular}

Tab.5. Kvantifikácia technológie pre horizont RS2(2).

Tab. 5. Quantification of technology for phase RS2(2).

obj. 9<smiles>c1ccccc1</smiles>
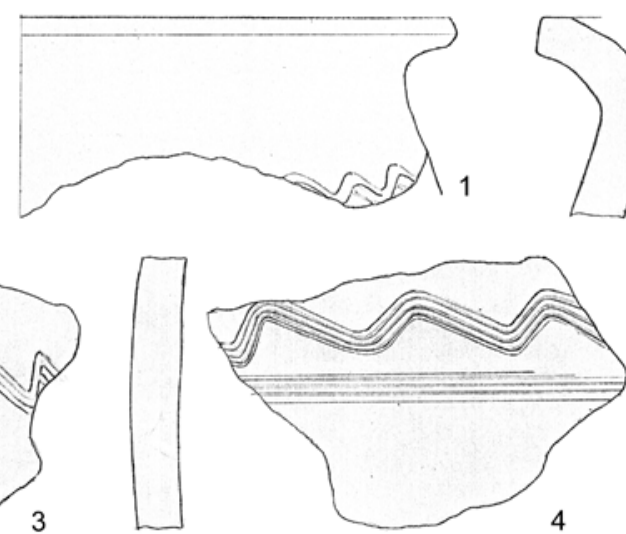

4

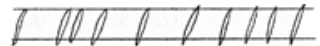
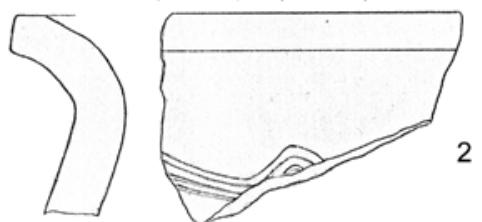

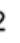

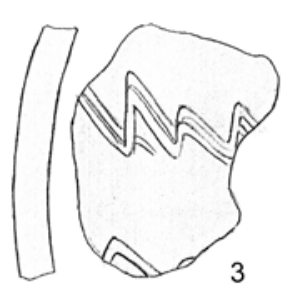

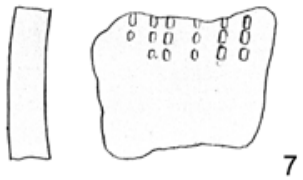

7
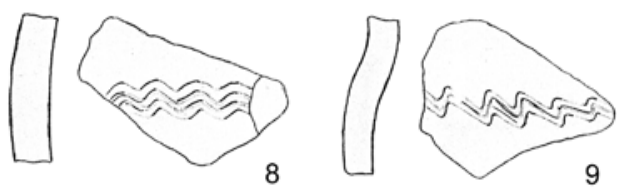

9

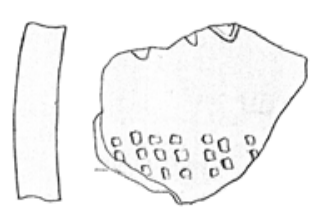

10
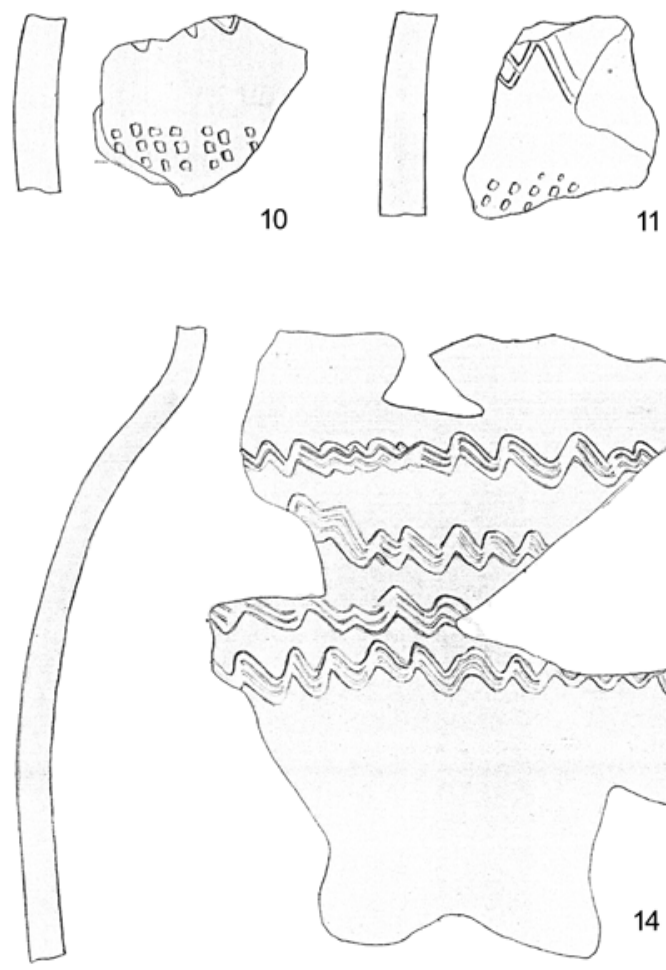

14
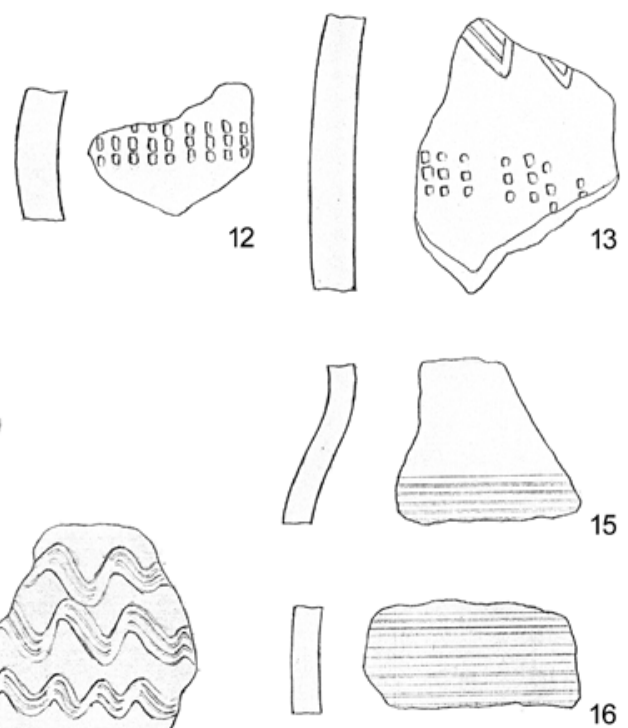

15

16

\section{.}




\begin{tabular}{lrrrrr}
\hline Materiál & I(HDV) & I(HZV) & I(super HDV) & I(super HZV) & II(JZV) \\
\hline obj. 7 & 0 & 32 & 0 & 2 & 3 \\
\hline obj. 21 & 0 & 15 & 2 & 1 & 1 \\
\hline obj. 24 & 0 & 23 & 0 & 0 & 0 \\
\hline obj. 79 & 0 & 45 & 0 & 2 & 0 \\
\hline obj. 83 & 1 & 29 & 0 & 3 & 1 \\
\hline obj. 92 & 1 & 26 & 0 & 2 & 1 \\
\hline obj. 101 & 0 & 41 & 0 & 0 & 1 \\
\hline obj. 104 & 0 & 34 & 0 & & 0 \\
\hline obj. 130 & 1 & 38 & & & 0 \\
\hline
\end{tabular}

Tab.6. Kvantifikácia materiálu pre horizont RS2(2).

Tab. 6. Quantification of material for phase RS2(2).
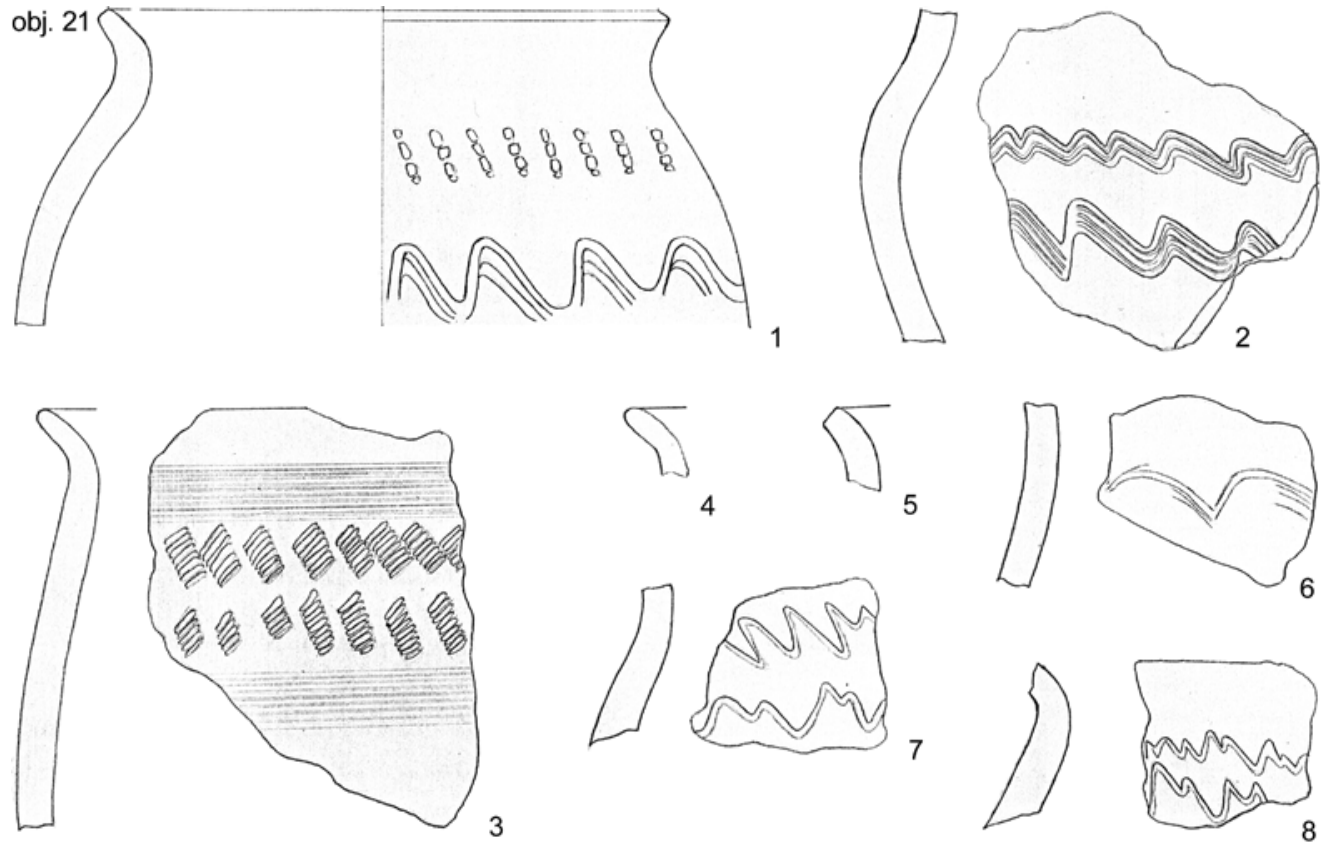
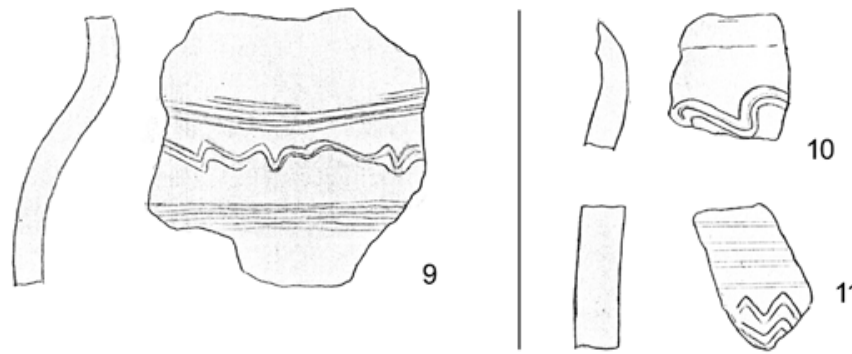

obj. 23

9

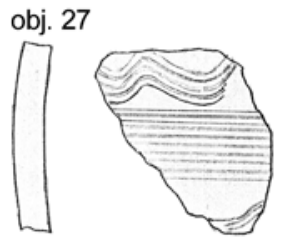

13

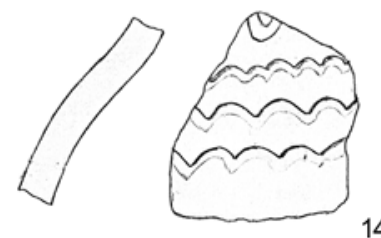

14
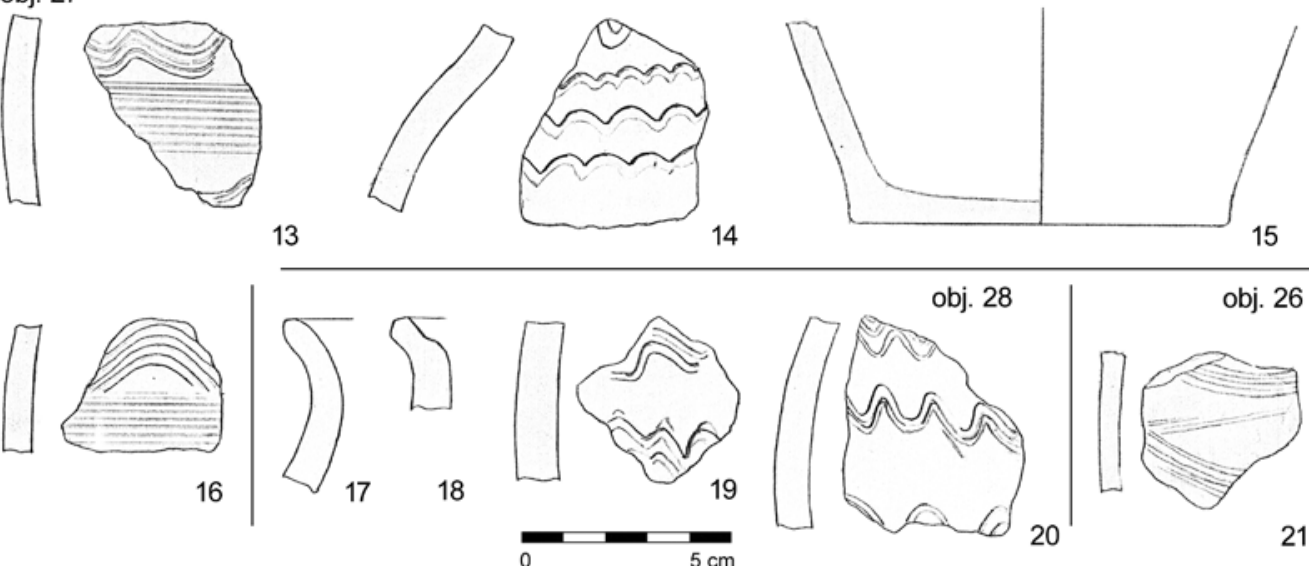

20

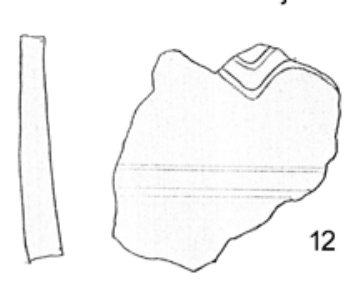

12 . 
\begin{tabular}{lllllllllllllllllllllllll}
\hline Výzdoba & A1 & A2 & A3 & B1 & B2 & B3 & C1 & C3 & C4 & C5 & C6 & D2 & E1 & E2 & F2 & F4 & F5 & G2 & H1 & H2 & H4 & I1 & J
\end{tabular}

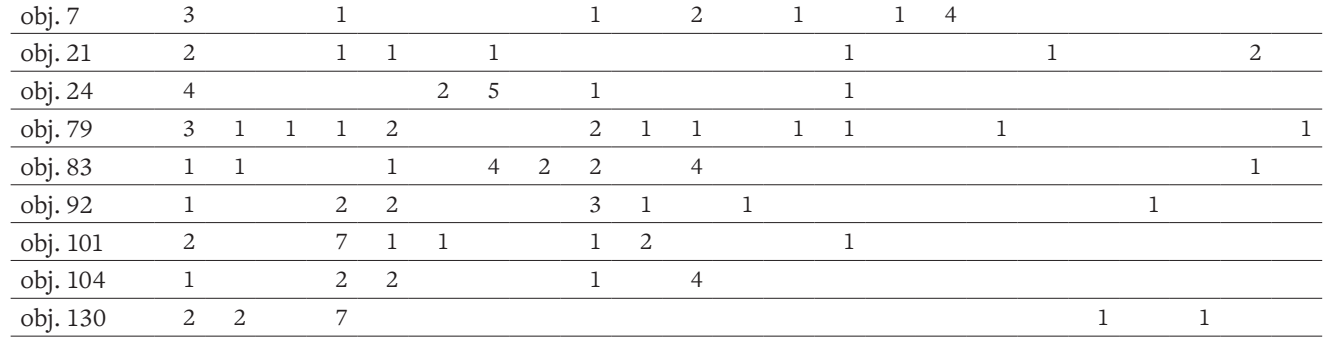

obj. 83
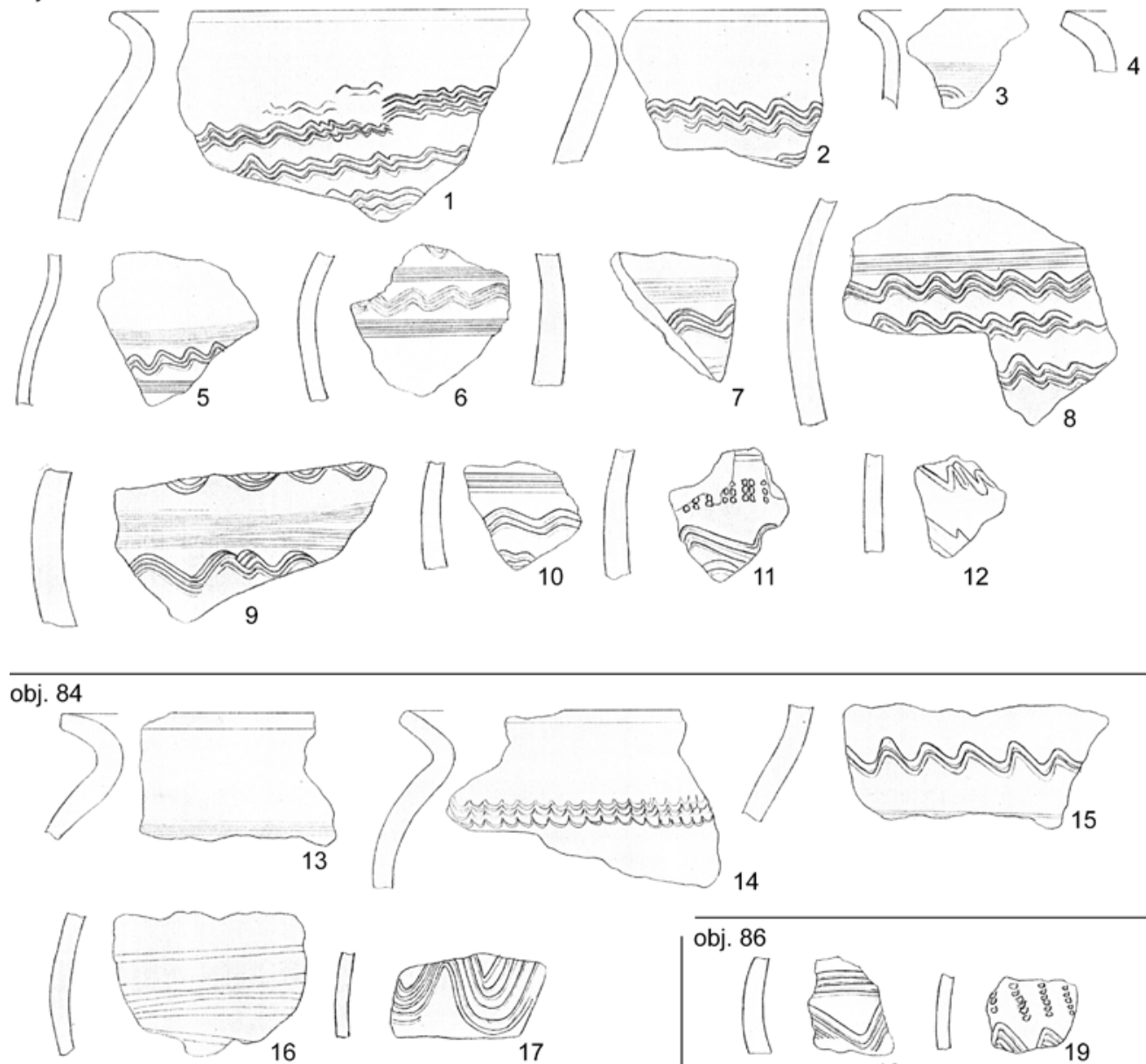

obj. 85
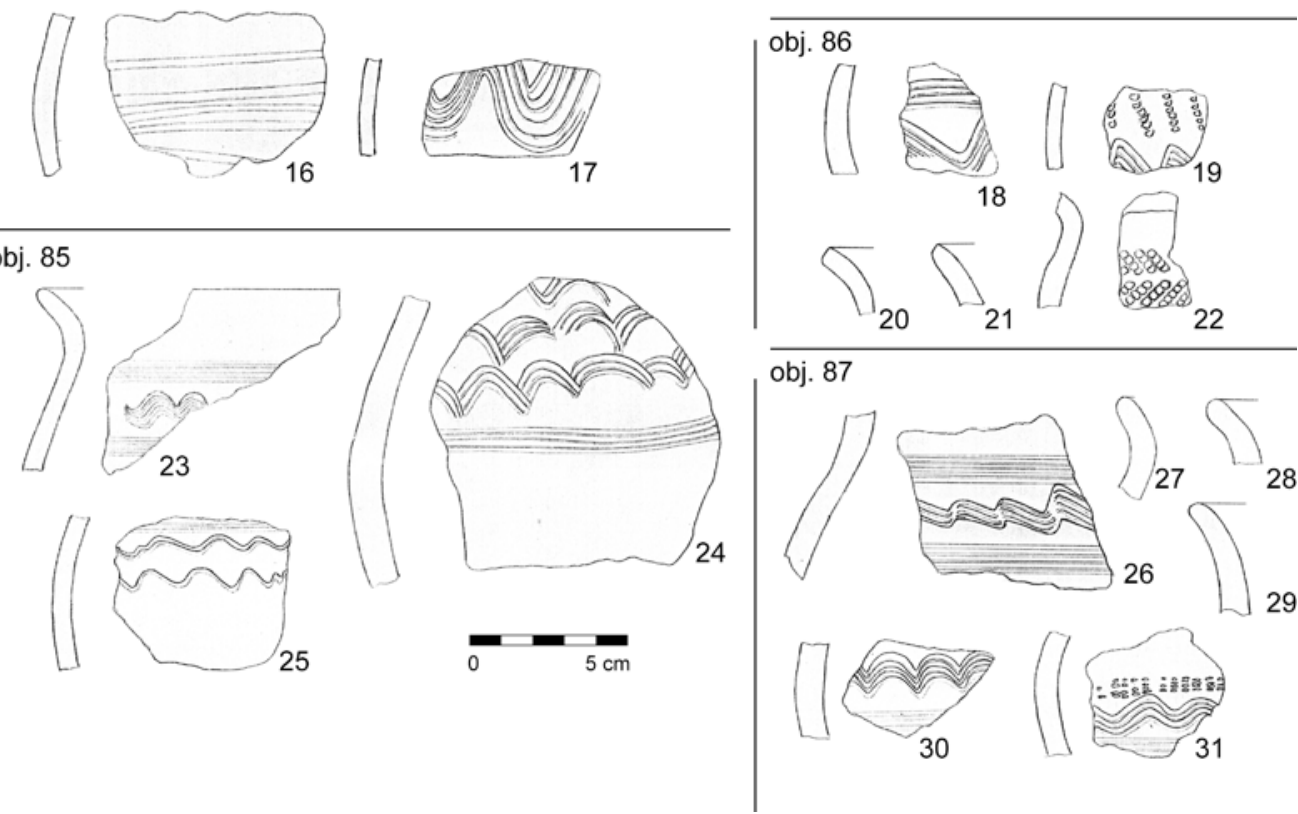

Tab. 7. Kvantifikácia typov výzdoby pre horizont RS2(2).

Tab. 7. Quantification of types of decorations for phase RS2(2).
Obr. 16. Výber keramiky z objektov 83-87. Podl'a Geisler 1992 obr. 112-116.

Fig. 16. Selection of pottery from features 83-87. After Geisler 1992, Fig. 112-116. 


\begin{tabular}{lrrrrrr}
\hline Okraje & A1 & A2 & B1 & B2 & B3 & C3 \\
obj. 7 & 3 & & 6 & & & 1 \\
\hline obj. 21 & & 2 & & 2 & & \\
\hline obj. 24 & 8 & 5 & & & \\
\hline obj. 79 & & 3 & 5 & 1 & 1 \\
\hline obj. 83 & 6 & 1 & 3 & & \\
\hline obj. 92 & 2 & & 4 & & \\
\hline obj. 101 & 2 & 3 & 9 & & \\
\hline obj. 104 & & 1 & 5 & & 1 \\
\hline obj. 130 & 2 & 1 & & 1 & \\
\hline
\end{tabular}

Tab. 8. Kvantifikácia okrajov pre horizont RS2(2).

Tab. 8. Quantification of rims for phase RS2(2).

obj. 95
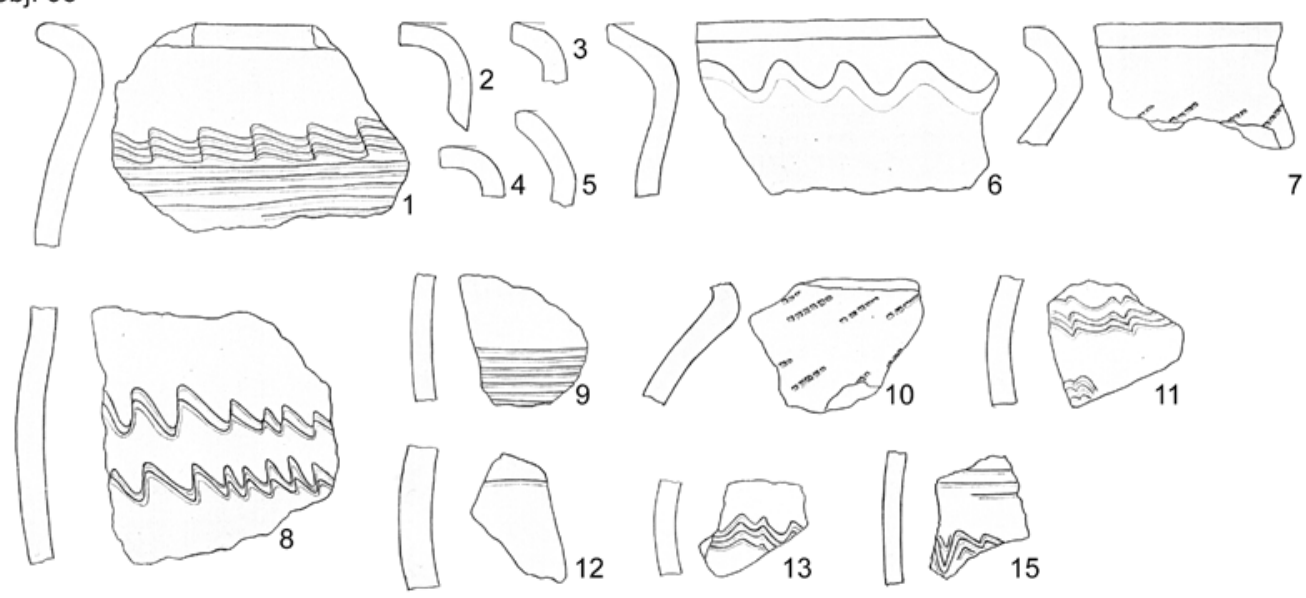

obj. 98
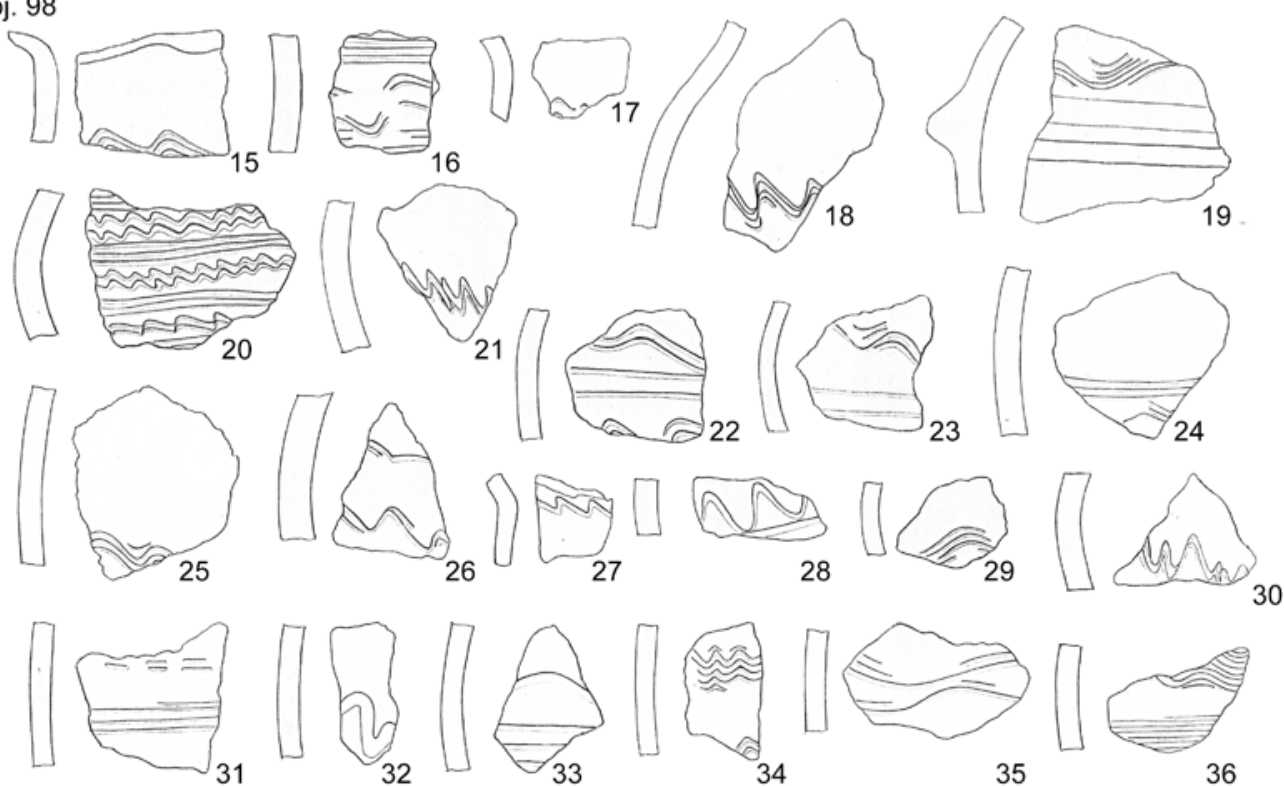

$\square \leqslant$
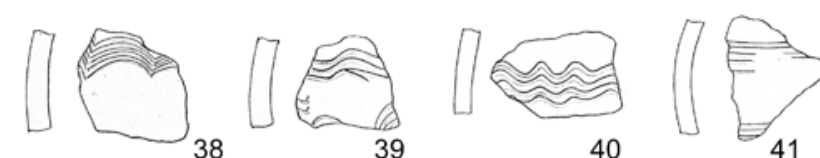

36

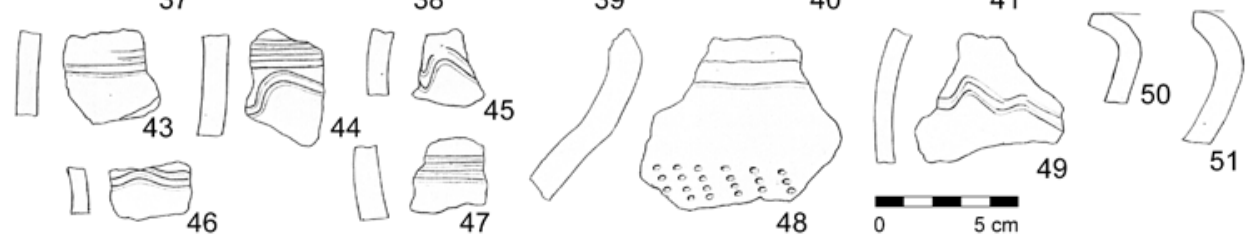

Obr. 17. Výber keramiky z objektov 95 98. Podl'a Geisler 1992, obr. 122-125.

Fig. 17. Selection of pottery from features 95, 98. After Geisler 1992 Fig. 122-125. 
derivátu (obr. 22: 9). V obj. 7 tvorí výzdoba, tvorená jednozubým nástrojom, približne $18 \%$ (šest̉ kusov), avšak nachádza sa na menších kusoch. Hrebeňovou výzdobou je zdobených sedem kusov, teda okolo $21 \%$. Takto zdobené sú aj najvýraznejšie kusy (obr. 13: 1, 3, 13). Okraje sú mierne pokročilejšie, avšak datované do starohradištnej doby. Preto bol objekt zaradený do fázy RS2(2). V obj. 21 tvorí hrebeňová výzdoba 18 \%(pät kusov), dva kusy (7\%) sú ryté jednozubým nástrojom a jeden kus má presnejšie nedatovatel'nú výzdobu (G2). Objekt 24 obsahuje starohradištnú výzdobu až na 12 kusoch (46\%), rytú jednozubým nástrojom len na jednom kuse. Objekt 79 má 12 kusov (27\%) hrebeňovej výzdoby a tri kusy rytej výzdoby jednozubým nástrojom (7\%). Hrebeňová výzdoba sa tiež nachádza na najväčších kusoch (obr. 22: 13, 14). V obj. 83 ju malo 15 kusov (45\%) a rytú jednozubým nástrojom iba jeden. V obj. 92 bolo devät kusov (33 \%) zdobených hrebeňom, po jednom kuse bolo rytých jednozubým nástrojom a nemalo datovanú výzdobu (H2). Objekt 101 jednozubú výzdobu takmer neobsahuje (až na jeden kus), ale hrebeňová výrazne prevažuje (okolo $32 \%$, 14 kusov). Zaujímavými kusmi keramiky v objekte sú dva zvonku zdobené okraje (obr. 23: 20, 21). Objekt 104 jednozubú výzdobu nemal vôbec. V obj. 130 bola výzdoba, tvorená jednozubým nástrojom, identifikovaná na dvoch kusoch, teda asi $5 \%$ a výrazne prevažuje výzdoba hrebeňová (obr. 25: 4, 6-9, 11, 13, 14), približne

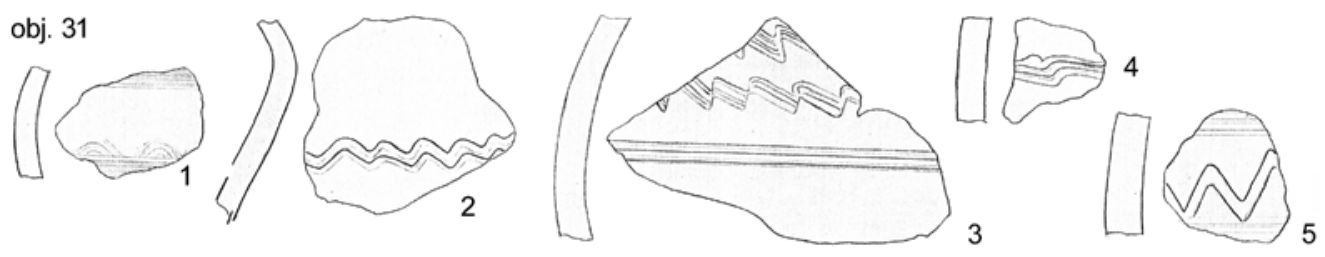

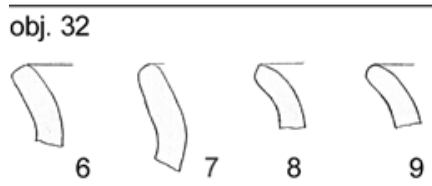

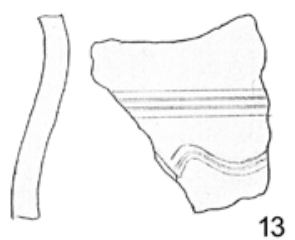

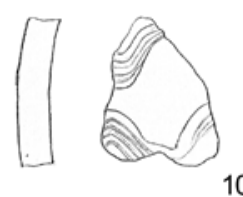
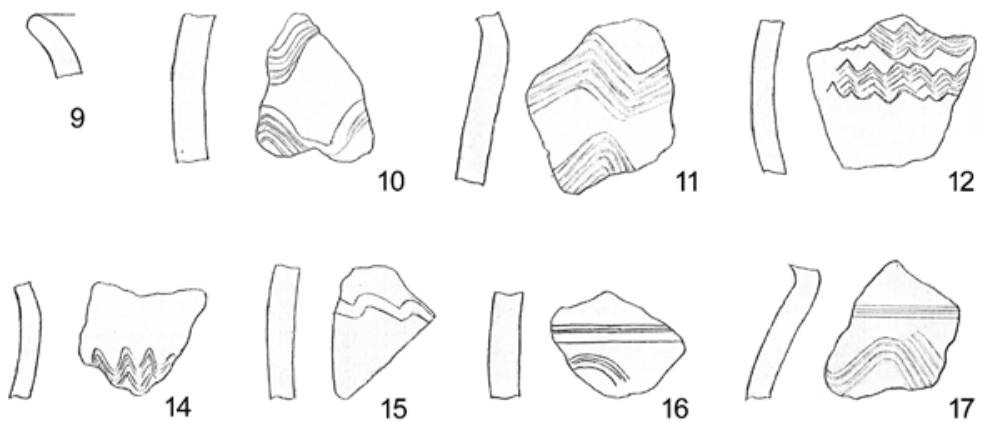

obj. 34

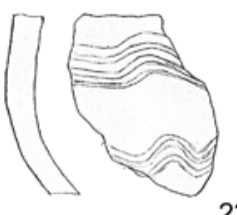

23
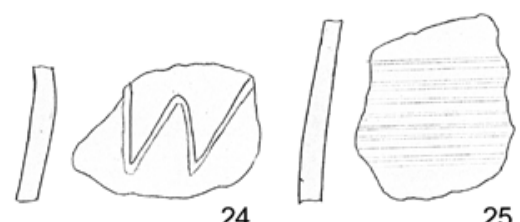

25

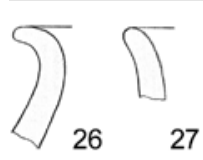

27

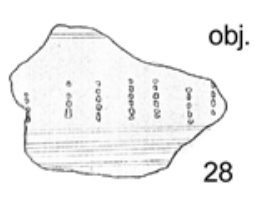

28
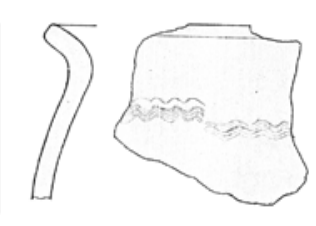

obj. 36

29

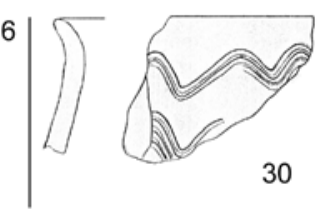

obj. 37

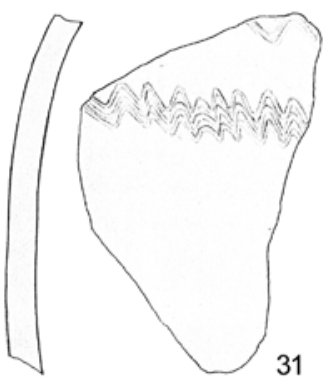

obj. 53
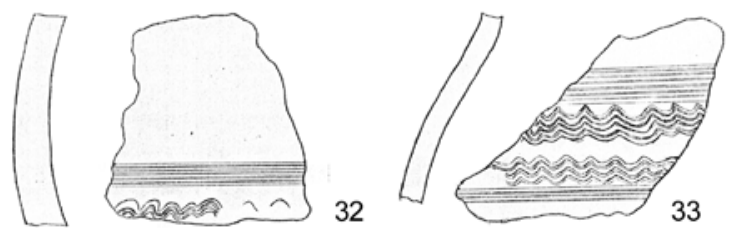

Obr. 18. Výber keramiky z objekto 31-37, 53. Podl'a Geisler 1992 obr. 86-89, 96.

Fig. 18. Selection of pottery from features 31-37, 53. After Geisler 1992, Fig. 86-89, 96. 
28 \% (11 kusov). Pre celú fázu RS2(2) je typický výskyt jednoduchých zaoblených alebo kužel'ovito zrezaných okrajov A1, A2 a B1. Jednoduché okraje sa vyskytujú vo vel'kom množstve aj v nasledujúcom horizonte. Typy B2, B3 a C3 tvoria mladšiu stredohradištnú intrúziu. Na percentuálnom zastúpení vidiet? jasnú prevahu jednoduchých typov okrajov aj hrebeňovitej výzdoby typickej pre RS2(2), s čím korešponduje aj druh materiálu (graf 2 - viz nižej).

Starohradištný keramický materiál z Brna-Medlánok je porovnatel'ný s inými včasnostredovekými lokalitami na Brnensku. Dôležitou starohradištnou lokalitou je Brno-Starý Lískovec (Čižmářová 1996, 284-288, obr. 4-8). Keramika fázy
RS2(1) z Medlánok je porovnatel'ná s I. horizontom keramiky zo Starého Lískovca. Pozorovat tu analógie vo výskyte keramiky s asymetrickou výzdobou, aj hrubé nepravidelné hrebeňové vlnovky (Macháček 2000, 47, obr. 6). Druhá fáza horizontu RS2 je porovnatel’ná s II. a III. horizontom keramiky zo Starého Lískovca. Hrebeňové vlnovky sú pravidelnejšie a na záver sa objavuje rytá výzdoba jednozubým nástrojom a nové typy ukončenia okrajov (Macháček 2000, 48-49, obr. 7, 8). Pri porovnaní s materiálom zo Starých Zámkov u Líšně je možné našu 1. fázu horizontu RS2 priradit k tamojšiemu 1. horizontu (Staňa 1994, 267, obr. 2) s tým rozdielom, že náš horizont neobsahuje prechodnú keramiku skupiny C podla D. Jelínkovej (1990, 254, 256-257).
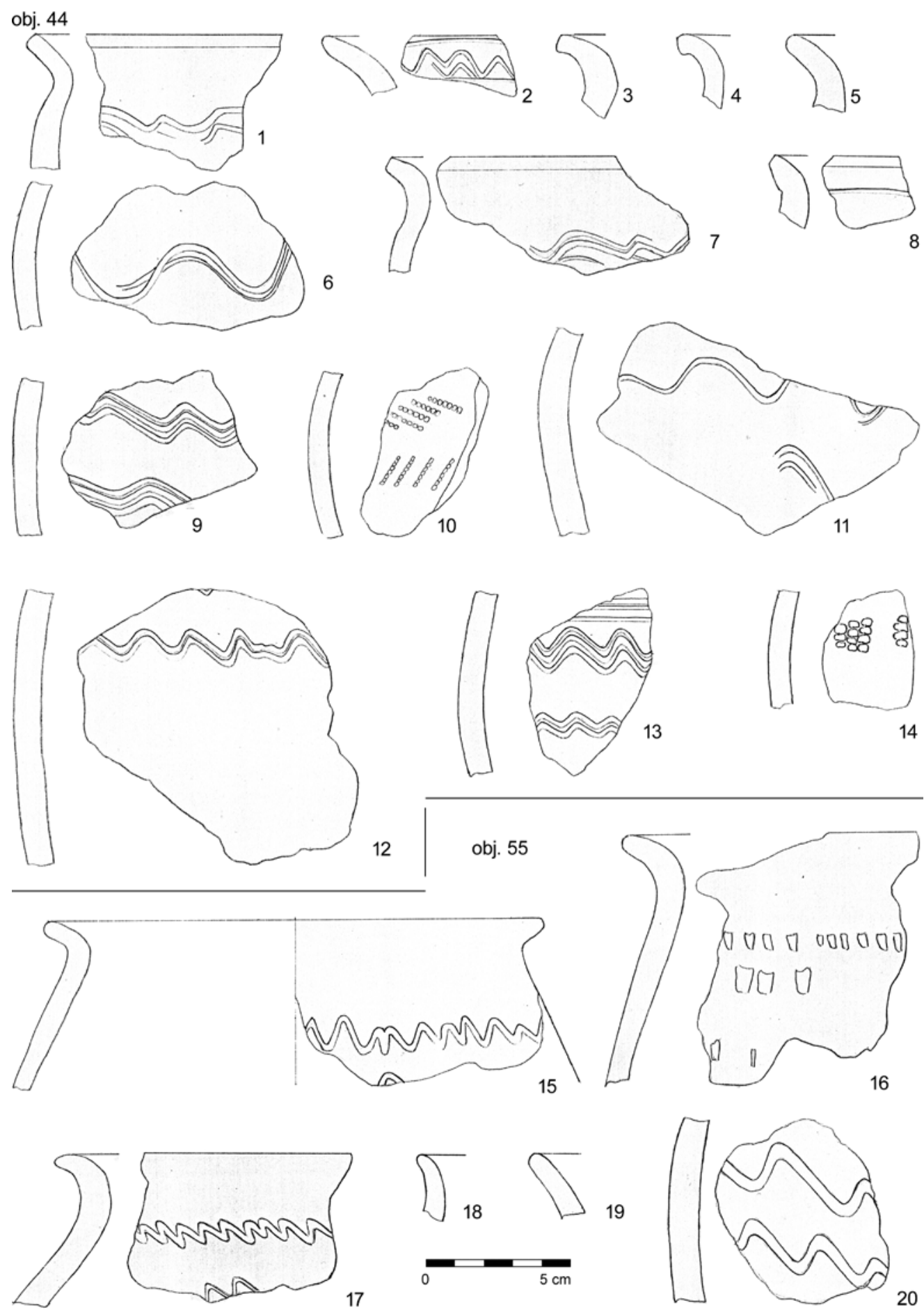
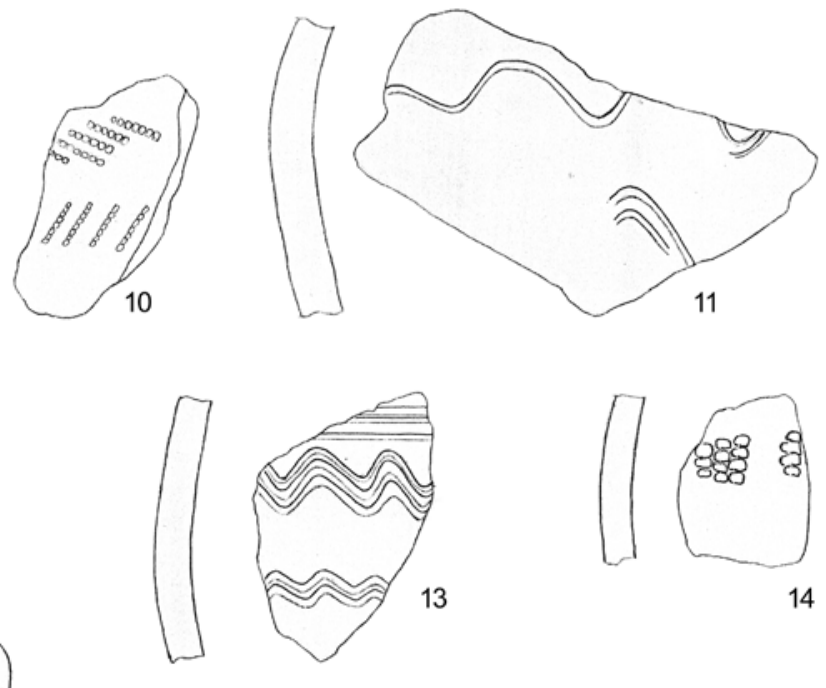

obj. 55
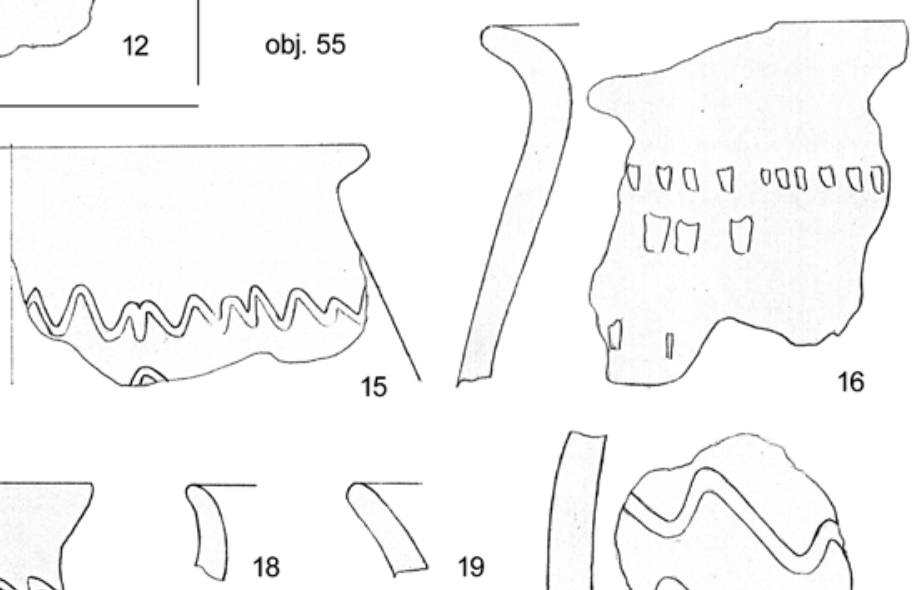

19
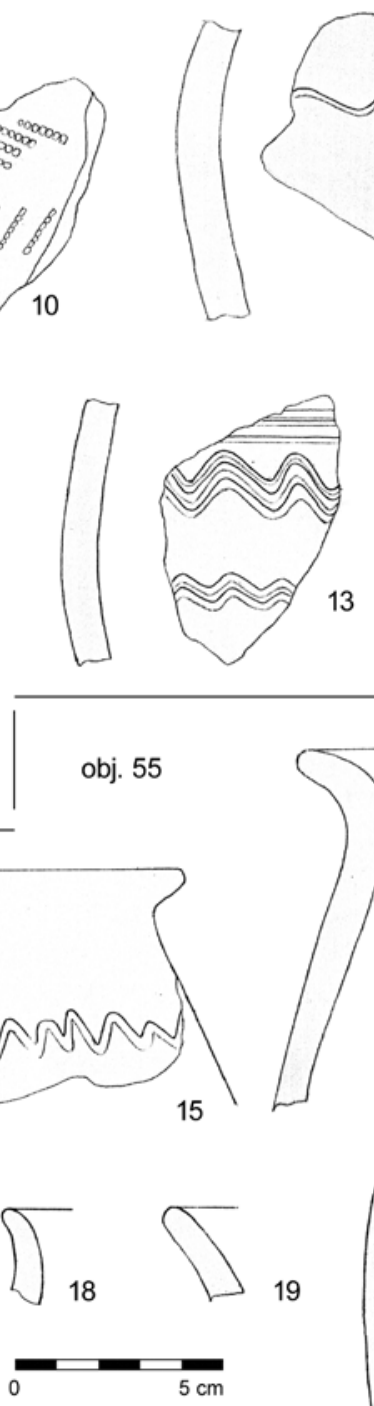

14 7

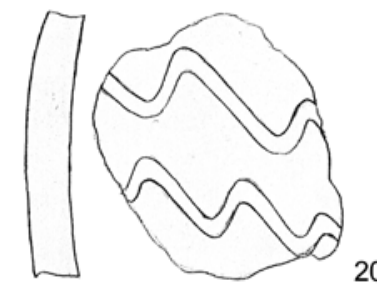

Obr. 19. Výber keramiky z objektu 44 55. Podl'a Geisler 1992, obr. 89-97.

Fig. 19. Selection of pottery from features 44, 55. After Geisler 1992 Fig. 89-97. 
Keramika pražského typu sa na hradisku nenachádzala. Druhý horizont Starých Zámkov je typický starohradištný, stotožnitel'ný s 2. fázou horizontu RS2 v Medlánkach (Staňa 1994, 270, obr. 5).

\subsection{RS3 - stredohradištné obdobie (800-950)}

Patria sem nádoby s prevahou výzdoby rytej jednozubým rydlom. Hrebeňová výzdoba však nad’alej pretrváva, aj ked’ v menšom množstve. Keramika je pravidelná, robená z valčekov na pomaly rotujúcom kruhu. Vzhl'adom ku konzervatívnejšiemu prístupu výrobcov aj nad'alej pretrváva časté užívanie vpichu, hrebeňového vpichu (obr. 21: 3; 26: 19, 30, 31, 34; 27: 1, 8) a odtlačkov (obr. 21: 7; 25: 17; 28: 20), občas v kombinácii s vyspelejším okrajom a výzdobou tvorenou jednozubým nástrojom (obr. 25: 1). Objavujú sa deriváty keramiky blučinského výrobného okruhu v obj. 19, 79 a 129 (obr. 22: 9; 25: 16, 19; 29: 6, 20) a možno aj dolnověstonického výrobného okruhu (obr. 26: 10), technické odtlačky na dne (obr. 9: 29; 20: 1;23: 9) a lišty na vydutinách nádob (obr. 13: 20; 17: 19; 26: 33). Nádoby sú bohatšie profilované, ojedinele sa na nich nachádza odsadenie hrdla (obr. 24: 6; 26: 1; 30: 22). Okraje sú zložitejšie, zväčša s vytiahnutou spodnou, hornou, alebo oboma hranami. Môžu byṫ zdobené. Ojedinele sa vyskytuje lievikovité a vodorovné zrezanie. Sú často konkávne prehnuté. Materiál je hrubý aj jemný dobre

obj. 65
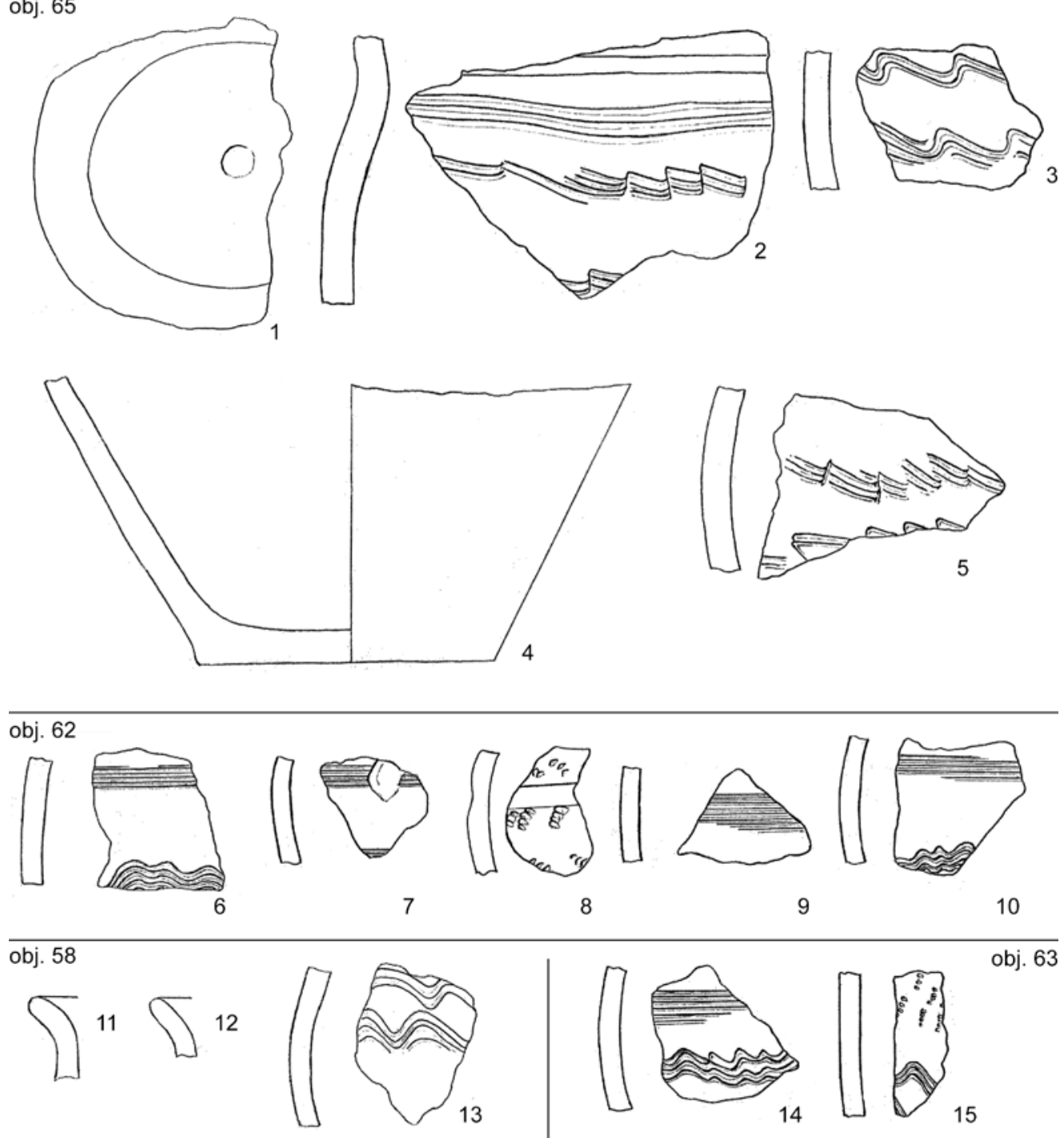

9

obj. 63
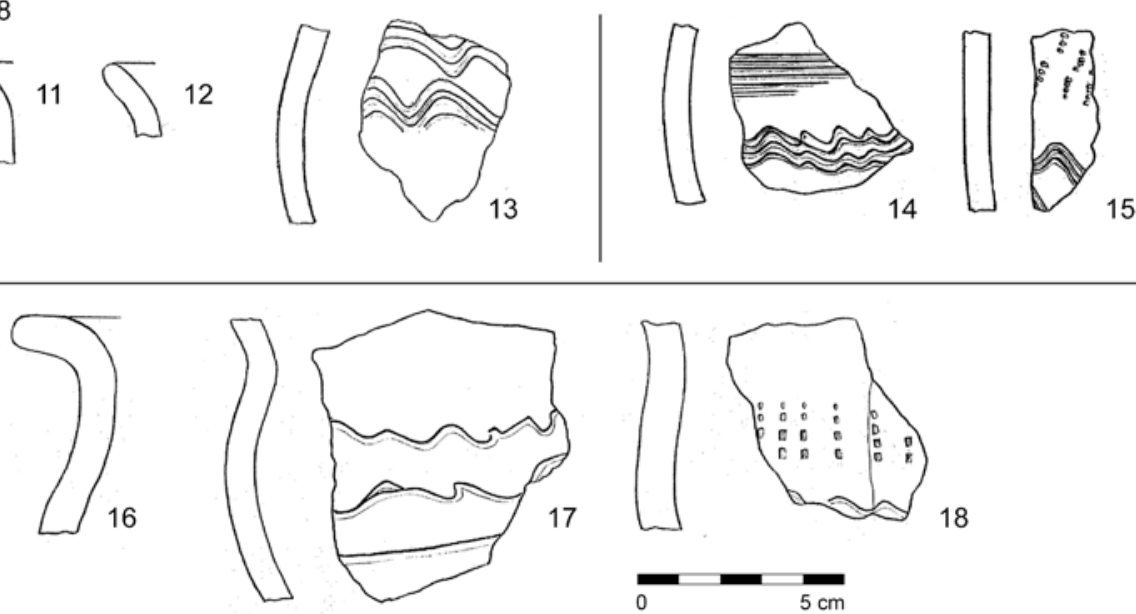

obj. 66

Obr. 20. Vybraná keramika z objektov 58, 62, 63, 65, 66. Podl'a Geisler 1992, obr. 98-105.

Fig. 20. Selection of pottery from features 58, 62, 63, 65, 66. After Geisler 1992, Fig. 98-105. 
vypálený. Stredohradištná keramika tvorila nevel'kú časť súboru, avšak obsahovala asi najviac výrazných kusov.

Do posledného tretieho horizontu bolo vd'aka početným charakteristickým kusom možné datovat’ osem objektov. Ide o obj. 19 (obr. 29), 30 (obr. 28), 44 (obr. 19, 21), 65 (obr. 20, 26), 84 (obr. 16), 113 (obr. 27, 30), 128 (obr. 30) a obj. 129 (obr. 25). Tento horizont je zároveň záverečným a určuje koniec osídlenia lokality. Materiál nenesie prvky mladohradištnej keramiky, avšak objavujú sa lišty na vydutinách, ktoré sú kombinované s hustou hrebeňovou výzdobou (obr. 17: 19; 26: 33) alebo sú zdobené šikmými zásekmi (obr. 10: 20). Ako upozornil L. Galuška (1989, 124-130), lišty sú na keramike funkčne pokročilejším prvkom. Objavovat’ sa majú už v predvel'komoravskom období, no lišty z Medlánok sú na základe sprievodnej keramiky datované do stredohradištného obdobia. Podobné nálezy líšt boli zaznamenané aj na sídlisku Olomouc-Slavonín Horní lán, kde sa nachádzali v malom počte štyroch kusov (Balcárková 2010, 179, obr. 19). Mali rovnaké príznaky, a to hrubý zle vypálený materiál, jednoduché okraje, hrebeňová výzdoba a absencia tuhy, ktorá je jedným z dôležitých indikátorov mladšej keramiky. Lišty boli interpretované ako predvoj nastupujúcich tendencií a označené za starohradištné (Balcárková 2010, 172, 178). Na hradisku Líšeň-Staré Zámky sa lišty v materiáli objavujú v stredohradištnom stupni. Majú zväčša obj. 44
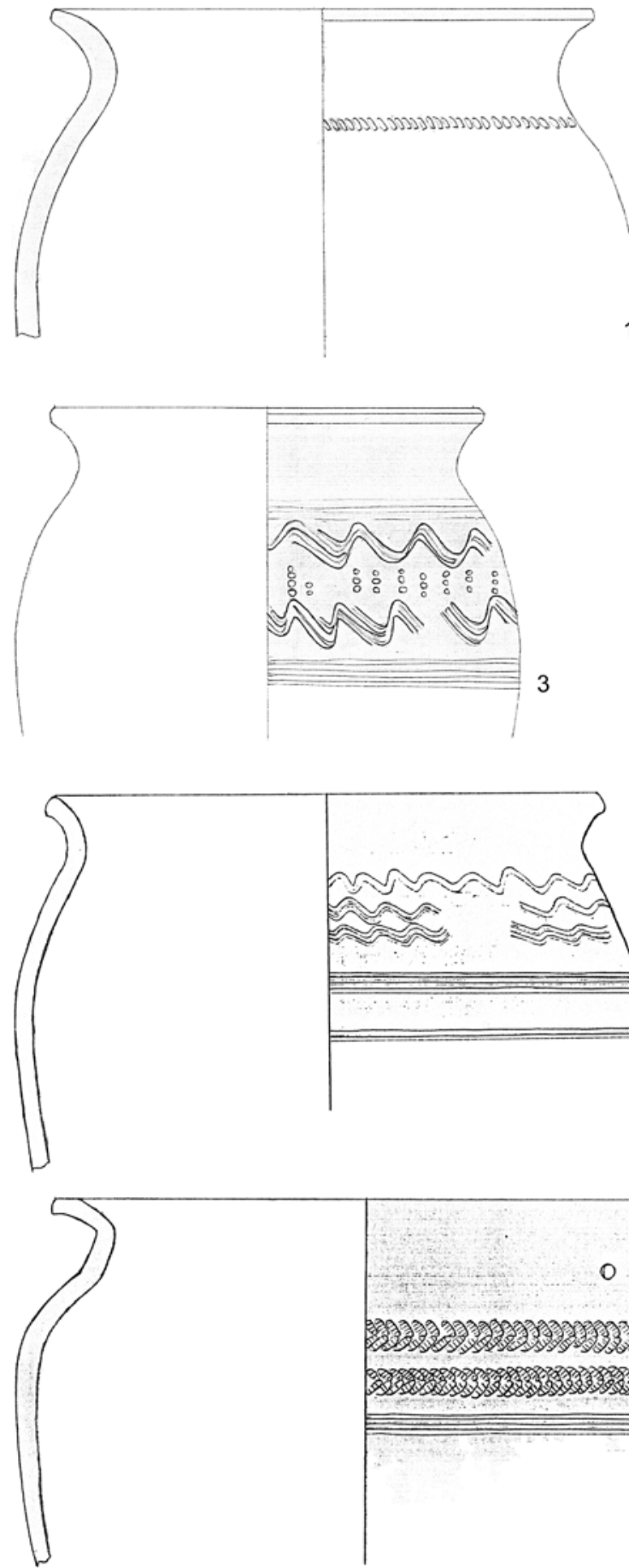
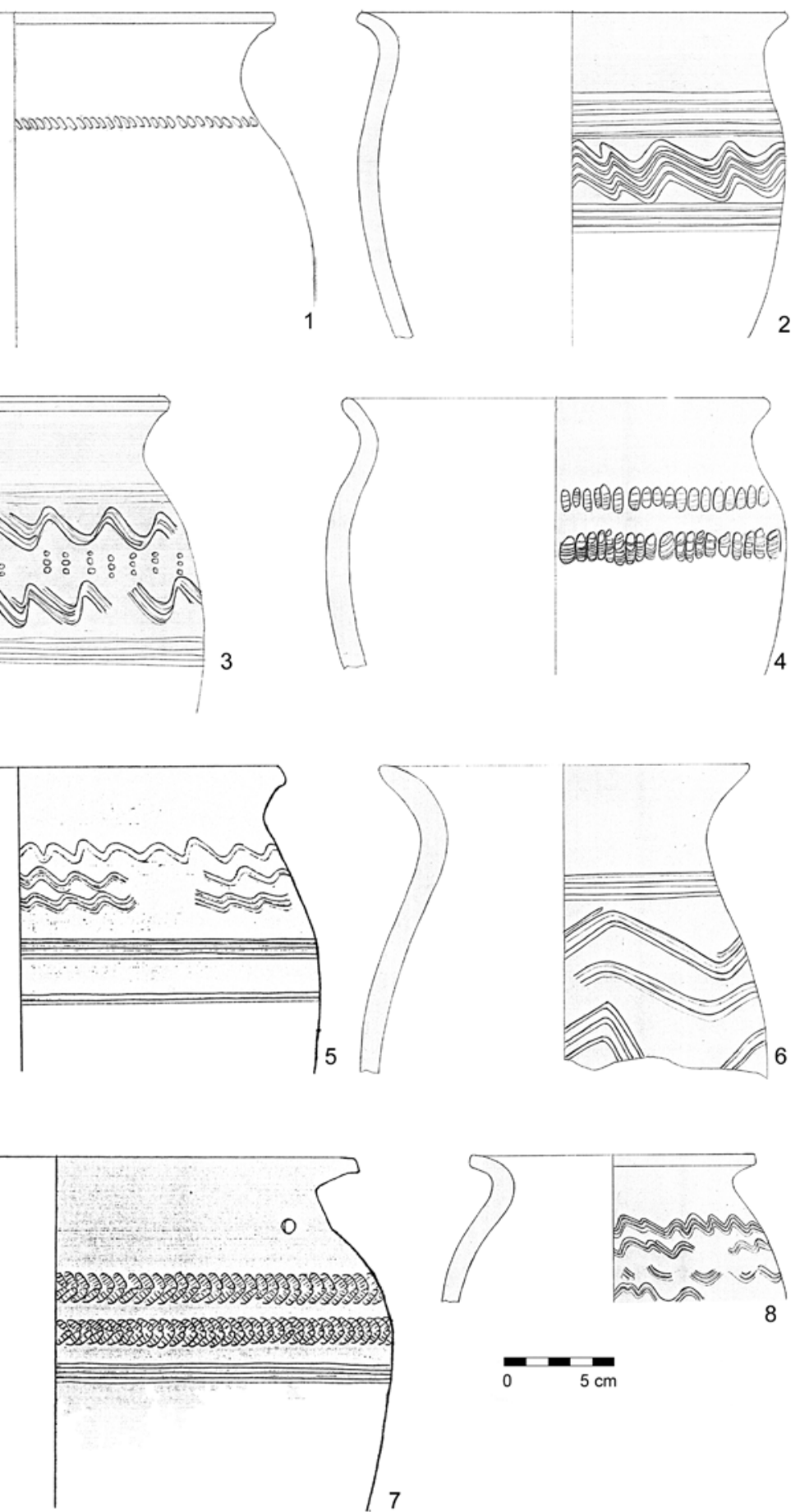

Obr. 21. Výber keramiky z objektu 44 Podl'a Geisler 1992, obr. 89-96.

Fig. 21. Selection of pottery from feature 44. After Geisler 1992, Fig. 89-96. 
trojuholníkový prierez a často sú kombinované s hrebeňovou aj s rytou výzdobou tvorenou jednozubým nástrojom. Objavuje sa aj prierez lichobežníkový (Kalčík 2015, 166, 168, obr. 20: 10; 177, obr. 27: 1, 10, 11; 183, obr. 31: 17). Vo väčšom množstve sa však na lokalite vyskytujú až od 6. horizontu starozámockej keramiky. Tá je už grafitová a tvorí mladohradištný materiál (Staňa 1994, 279, obr. 13: 10-12). Tri podobné lichobežníkové a jedna polkruhová lišta sa nachádzali aj na keramike z lokality Bořitov-U Badálka, Nepluště a Bořitov-Niva (Malach 2011, tab. 1: 4; 4: 5; 6: 19; 7:21). Dve lichobežníkové lišty boli zároveň zdobené zásekmi. Súbory boli takisto datované do stredohradištného obdobia (Malach 2011, 21-22).
Kvantifikačné tabul'ky (tab. 9-12) ukazujú už spomínané špecifiká nálezov z vidieckych osád. Technológia pomalého obtáčania viditel'ne pretrváva. Rovnako ako v predchádzajúcom horizonte prevažuje zle vypálený hrubý materiál. Výzdoba sa radikálne nemení, nápadný je nárast rytej výzdoby jednozubým nástrojom (D2-G2). Typy okrajov sú obohatené o profilovanejšie typy, konkrétne B2, B3, B4, C3 a D1. Objekt 19 má jasnú prevahu rytej výzdoby jednozubým nástrojom, ktorá tvorí $25 \%$, teda 12 kusov oproti $23 \%$ (11 kusov) hrebeňovitej výzdoby. Pozorujeme tiež prehnutejšie okraje, vel'mi vyspelé kusy (obr. 29: 1, 14, 16) a aj kusy derivátov blučinského okruhu (obr. 29: 6, 20). Objekt 30 obsahuje štyri kusy hrebeňovitej (asi $17 \%$ ) a štyri obj. 75
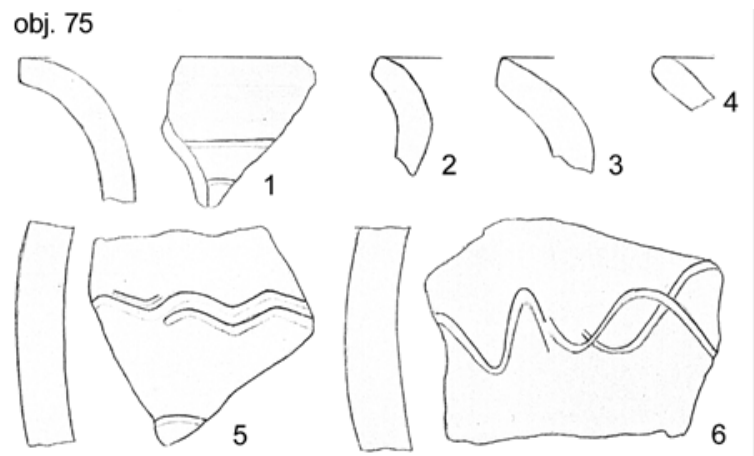

obj. 77
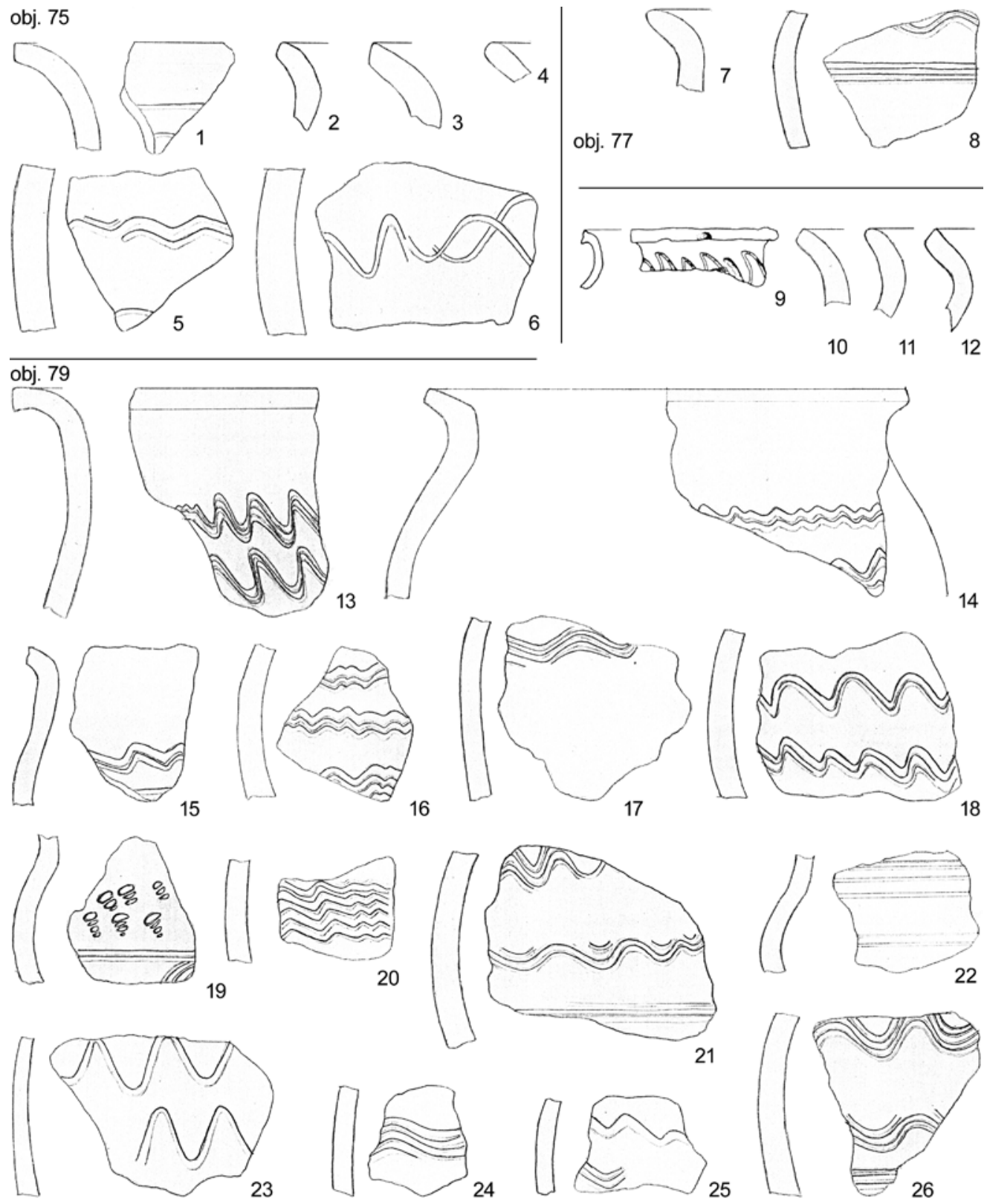

18
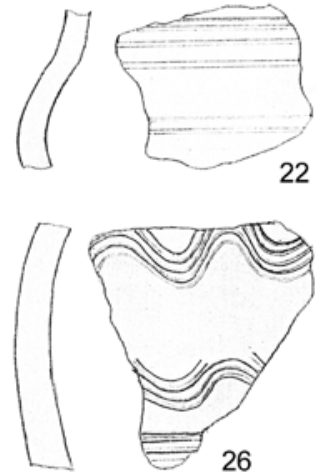

26
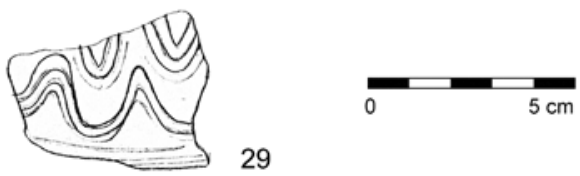

29

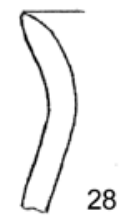

28
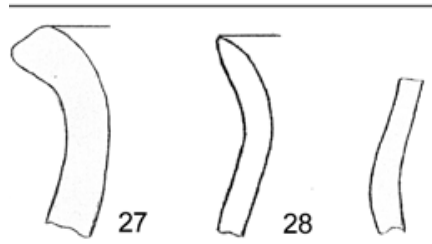

obj. 81 obj. 76
Obr. 22. Výber keramiky z objektov 75-77, 79, 81. Podl'a Geisler 1992, obr. 109-112.

Fig. 22. Selection of pottery from features 75-77, 79, 81. After Geisler 1992, Fig. 109-112. 
kusy jednozubej výzdoby (okolo $17 \%$ ), ktorá sa spolu s vpichmi nachádza na najvýraznejších kusoch (obr. 28: 19, 20). Azda najzaujímavejším objektom na sídlisku z hl’adiska keramického súboru bol objekt 44. Obsahoval až osem signifikantných a dobre zachovaných kusov nádob s kompletnou výzdobou a nepoškodeným okrajom (obr. 21: 1-8). Tento súbor patril na lokalite k najmenej fragmentarizovaným. Medzi nálezmi vyčnieva nádoba s vyvŕtaným reparačným otvorom pod okrajom (obr. 16: 4). Dobre zachované kusy sú zdobené hrebeňovou a rytou výzdobou tvorenou jednozubým nástrojom či vpichmi. Motívy výzdoby sú pomerne v rovnováhe. Hrebeňové motívy tvoria $35 \%$ (14 kusov) a ryté jednozubým nástrojom osem kusov (20\%). Motív „iné“ predstavujú odtlačky (obr. 21: 1, 4, 7). Technológia aj materiál nasledujú výrobné trendy na lokalite. Okraje nie sú typicky stredohradištné, avšak ani to nemusí byt’ vzhl'adom k vidieckemu prostrediu nič výnimočné. Práve tento objekt dokazuje dlhodobé prežívanie starších výzdobných motívov hlboko do stredohradištného obdobia, nakol'ko sú v prítomnosti očividne mladších kusov (obr. 21: 5-7). Prítomnosť vel'kých kusov nádob a menšia fragmentarizácia môže naznačovat, že dané kusy tam boli zámerne uložené a nedostali sa tam splavom z okolitých vrstiev, čo je doklad ukladania tzv. sekundárneho odpadu (Kuna 2015, 282) na lokalite. V objekte 65 bol vypozorovaný výskyt nádob s bohato profilovaným a odsadeným hrdlom (obr. 26: 10, 14, 15).

obj. 99
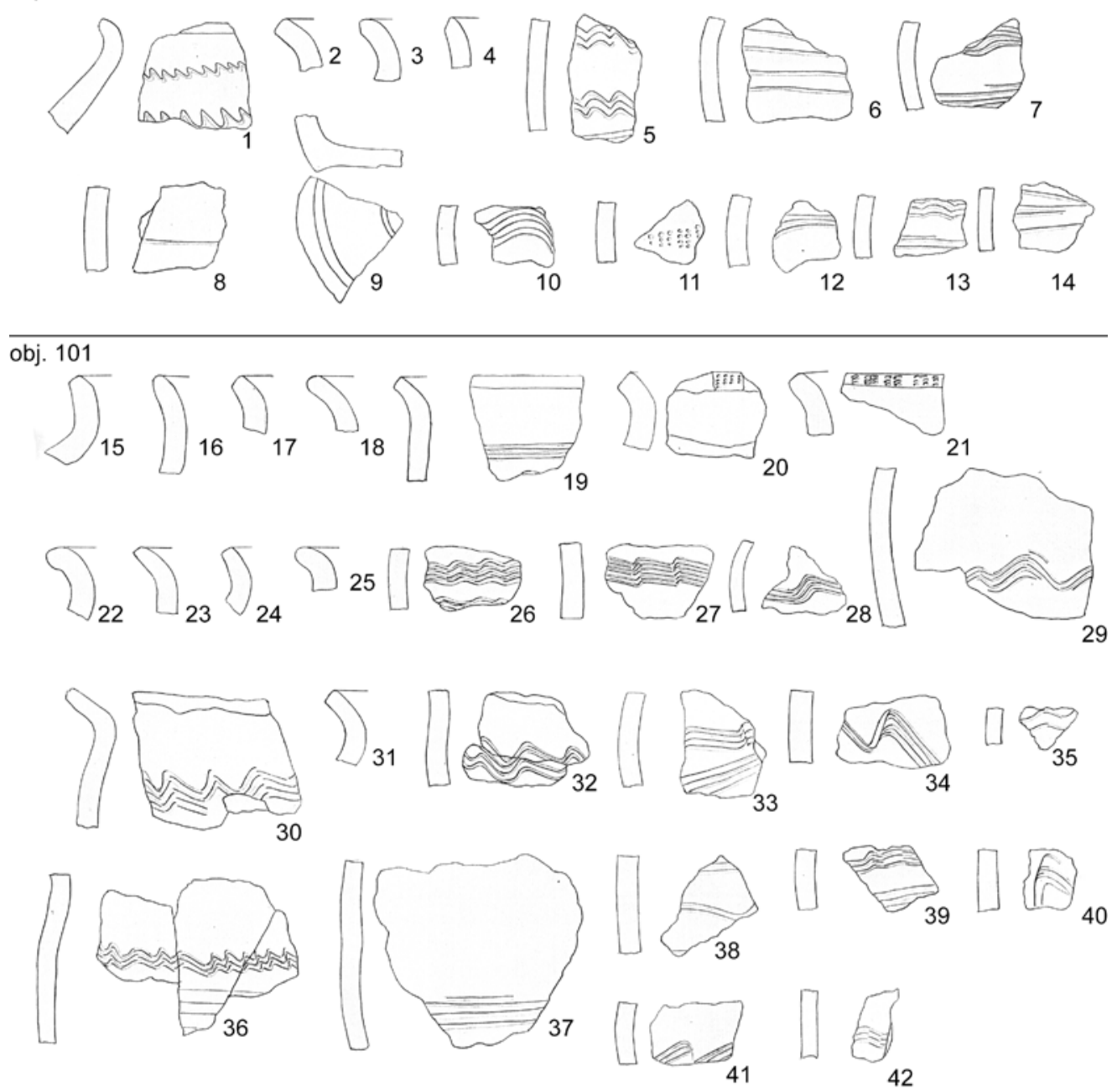

obj. 103
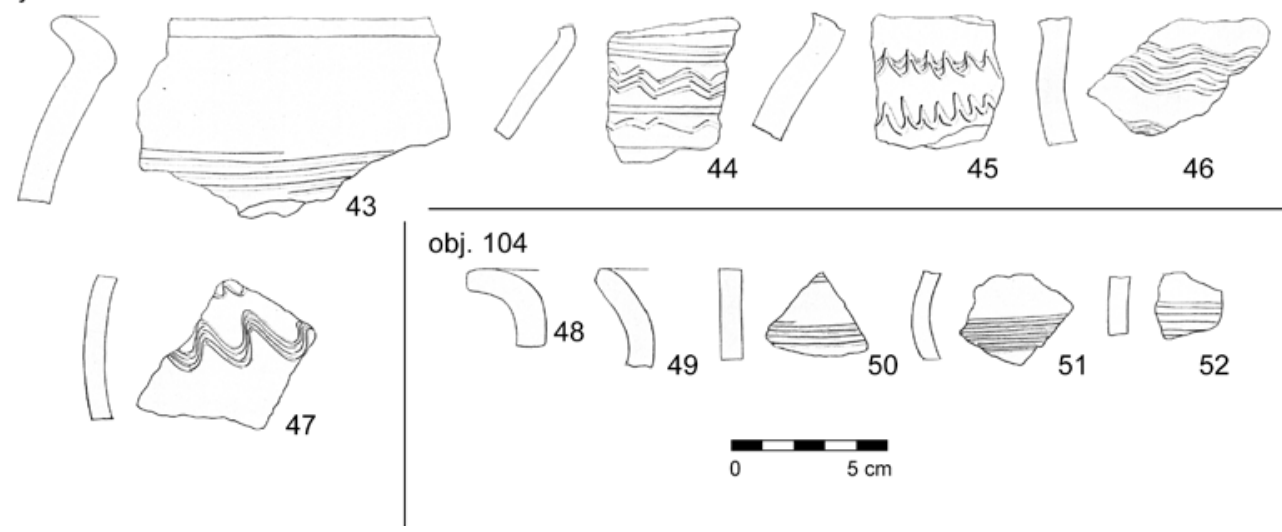

45

46

Obr. 23. Výber keramiky z objektov 99, 101, 103, 104. Podl'a Geisler 1992 obr. 125-129.

Fig. 23. Selection of pottery from features 99, 101, 103, 104. After Geisler 1992, Fig. 125-129. 


\begin{tabular}{lrrrrr}
\hline Technológia & Nesledované & $\begin{array}{r}\text { Obtáčanie silno } \\
\text { formujúce }\end{array}$ & $\begin{array}{r}\text { Obtáčanie slabo } \\
\text { formujíćce }\end{array}$ & V ruke & Počet jedincov \\
\hline obj. 19 & 18 & 4 & 26 & 0 & 48 \\
\hline obj. 30 & 10 & 2 & 9 & 2 & 23 \\
\hline obj. 44 & 4 & 0 & 32 & 3 & 39 \\
\hline obj. 65 & 9 & 3 & 40 & 8 & 59 \\
\hline obj. 84 & 1 & 4 & 6 & 1 & 12 \\
\hline obj. 113 & 27 & 0 & 27 & 0 & 54 \\
\hline obj. 128 & 18 & 4 & 29 & 0 & 100 \\
\hline obj. 129 & 40 & 1 & 28 & 0 & 69 \\
\hline
\end{tabular}

Tab. 9. Kvantifikácia technológie pre horizont RS3.

Tab. 9. Quantification of technology for horizon RS3.

obj. 104
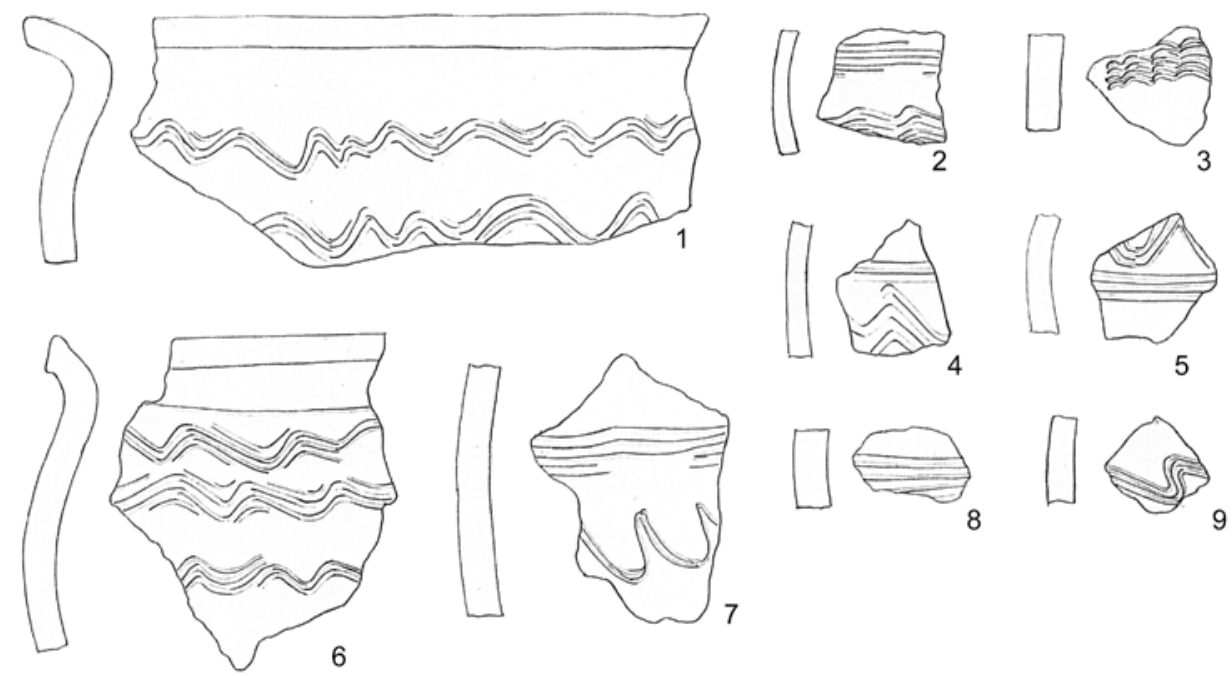

obj. 106
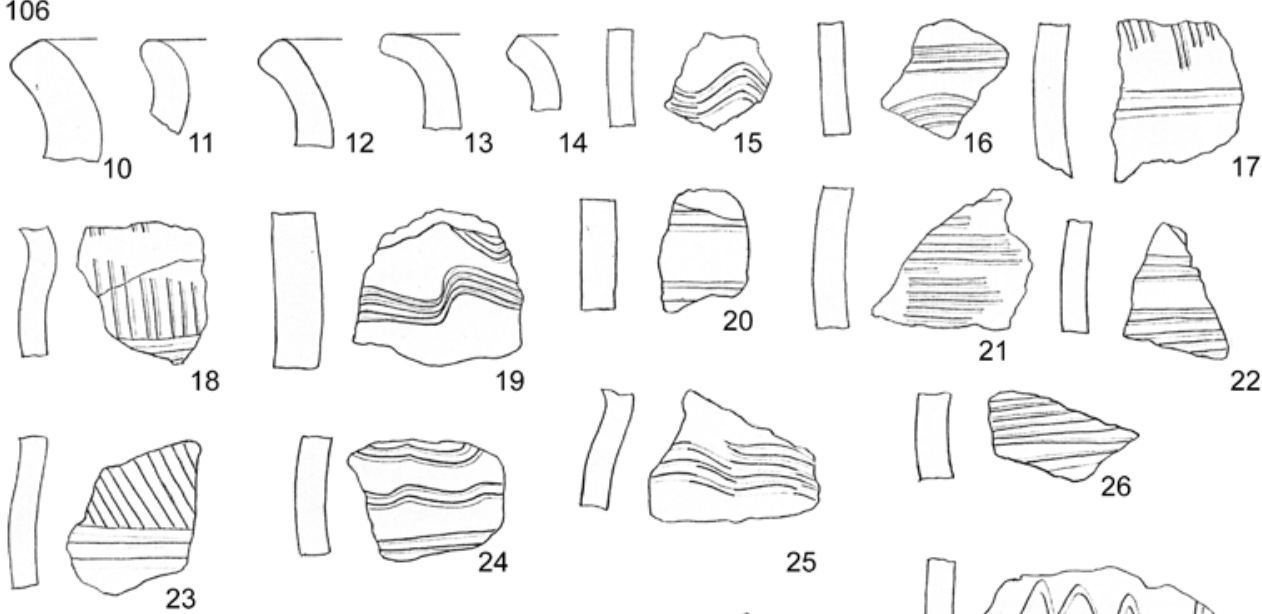

22
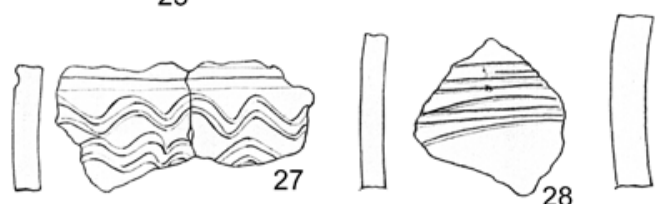

25
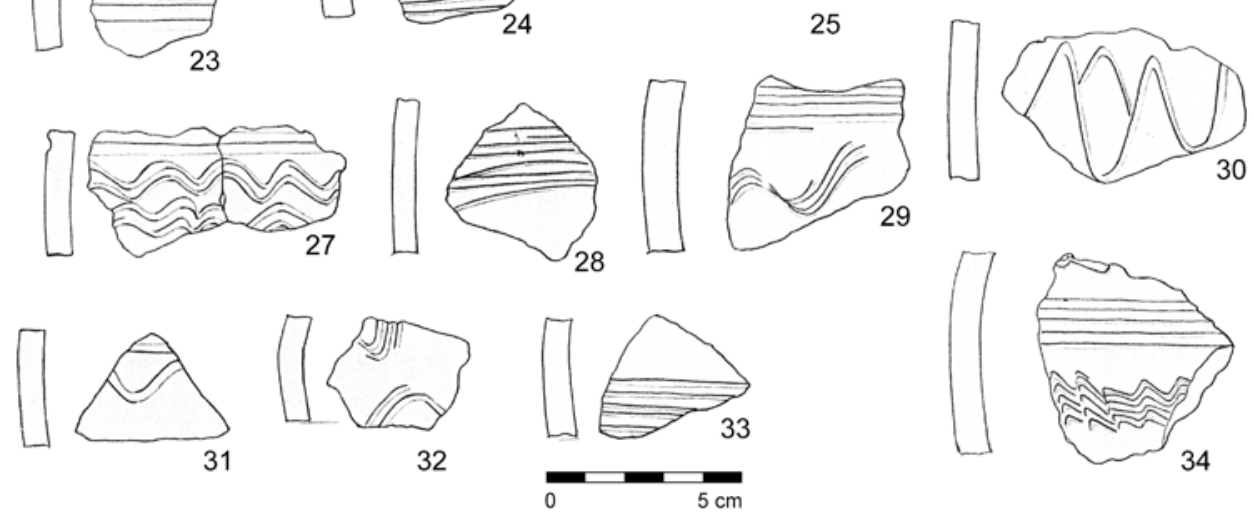

Obr. 24. Výber keramiky z objektov 104, 106. Podl'a Geisler 1992, obr. 128-131.

Fig. 24. Selection of pottery from features 104, 106. After Geisler 1992 Fig. 128-131. 


\begin{tabular}{lrrrr}
\hline Materiál & I(HDV) & I(HZV) & I(super HZV) & II(JZV) \\
\hline obj. 19 & 9 & 34 & 0 & 4 \\
\hline obj. 30 & 0 & 21 & 2 & 0 \\
\hline obj. 44 & 1 & 35 & 3 & 0 \\
\hline obj. 65 & 0 & 51 & 8 & 0 \\
\hline obj. 84 & 0 & 10 & 1 & 0 \\
\hline obj. 113 & 1 & 53 & 0 & 0 \\
\hline obj. 128 & 4 & 96 & 0 & 0 \\
\hline obj. 129 & 3 & 66 & 0 & 0 \\
\hline
\end{tabular}

Tab. 10. Kvantifikácia materiálu pre horizont RS3.

Tab. 10. Quantification of material for horizon RS3.
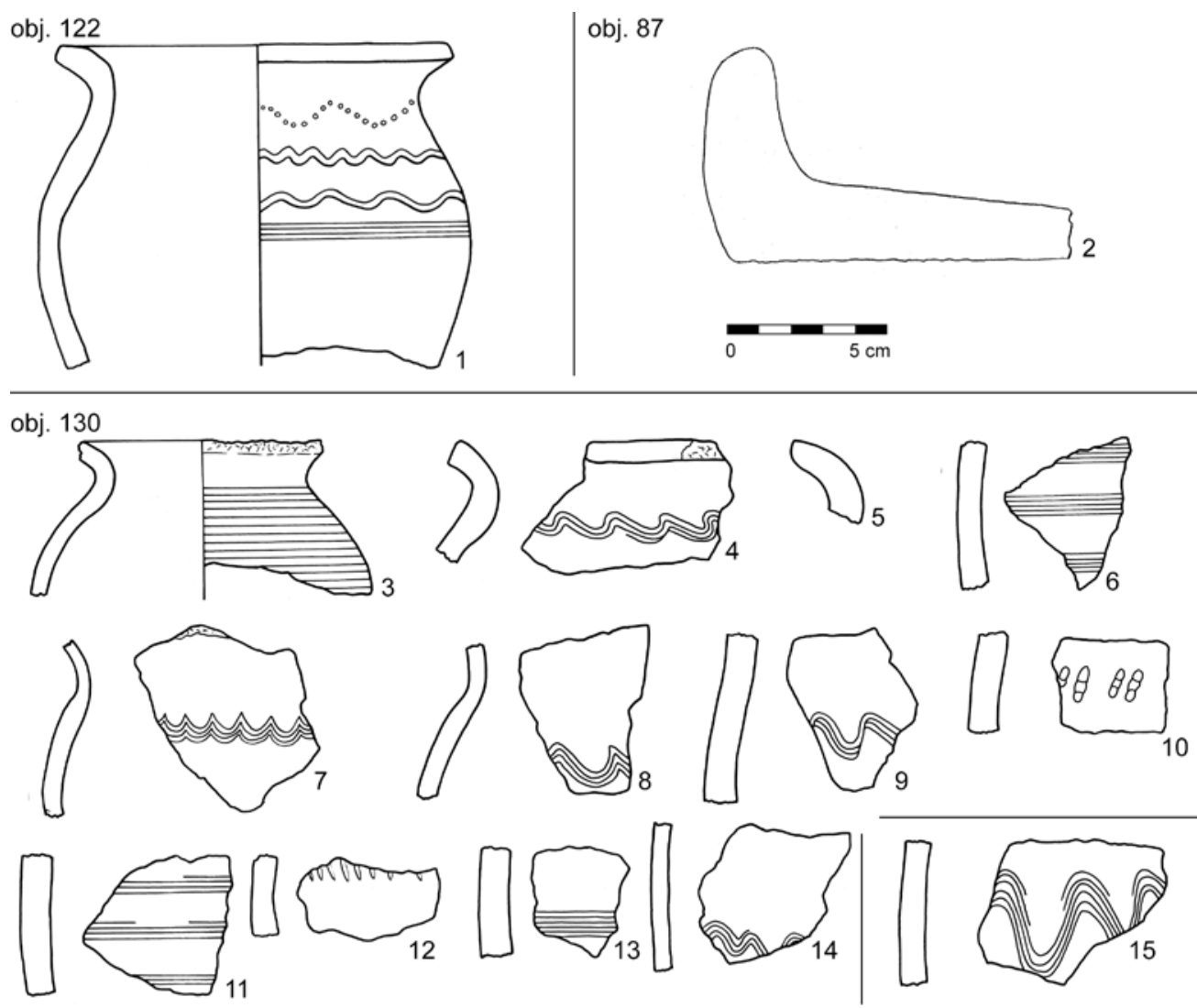

obj. 129
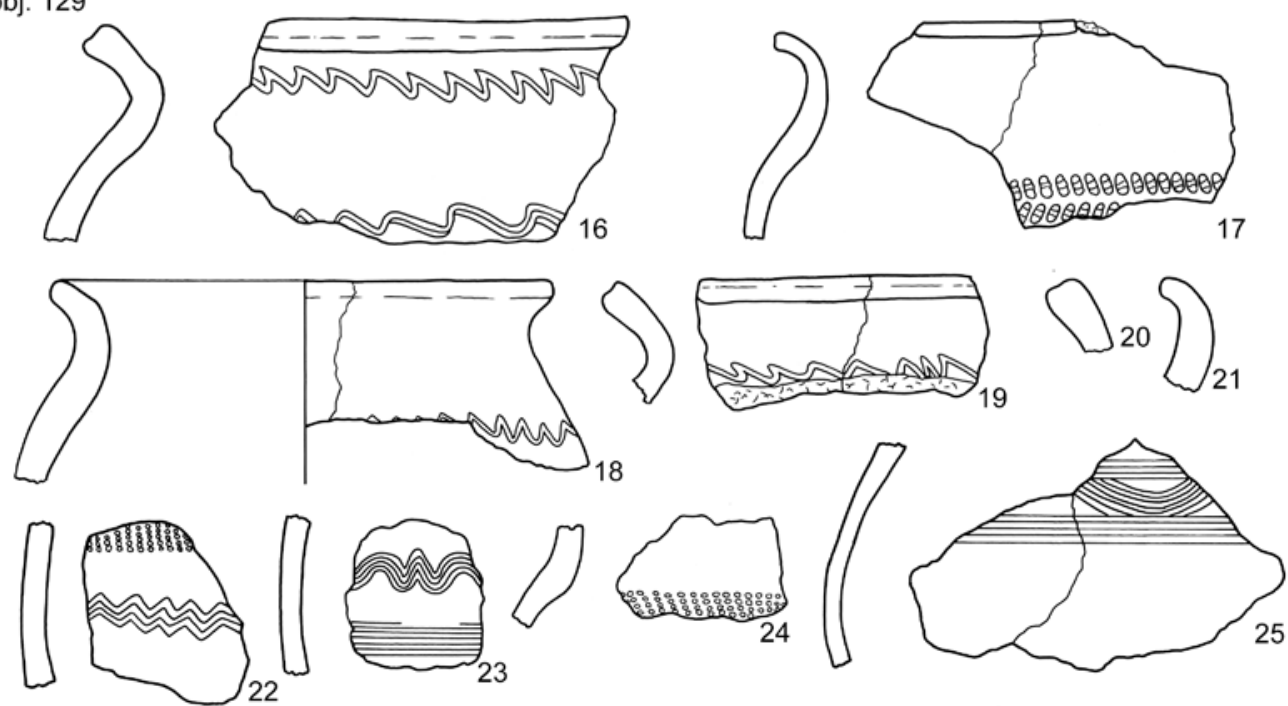

Obr. 25. výber keramiky z objektov $122,129,130$ (kresba J. Benech) a pražnica z objektu 87. Podl'a Geisler 1992, obr. 131.

Fig. 25. Selection of pottery from features 122, 129, 130 (drawing by $\mathrm{J}$. Benech) and the roasting tray from feature 87. After Geisler 1992, Fig. 131. 


\begin{tabular}{|c|c|c|c|c|c|c|c|c|c|c|c|c|c|c|c|c|c|c|c|c|c|c|c|c|c|c|c|c|}
\hline Výzdoba & A1 & A2 & A3 & B1 & B2 & B3 & C1 & C3 & C4 & C5 & C6 & D2 & D3 & E1 & E2 & $\mathbf{E 3}$ & F1 & F2 & F4 & F5 & G1 & G2 & H1 & $\mathrm{H} 2$ & 11 & 13 & 19 & J \\
\hline obj. 19 & 1 & 1 & & 5 & 2 & & & & & 1 & & 3 & & 3 & 1 & & 2 & & & 2 & 1 & & & & 1 & & & \\
\hline obj. 30 & 1 & 1 & & 1 & 1 & & & & & & & 1 & & 1 & & & & & & 1 & & 1 & 1 & & & & & \\
\hline obj. 44 & 3 & 2 & & 2 & & 1 & 1 & & 3 & 1 & & 2 & & 2 & 1 & & & & & & & & 2 & 1 & 1 & & & 2 \\
\hline obj. 65 & 9 & & & 4 & 8 & 1 & 1 & 1 & 1 & 2 & 1 & & & & & & & & 1 & & & & 1 & & 1 & & 2 & \\
\hline obj. 84 & 2 & & & 3 & & 1 & & & 1 & & & 1 & & & & & & & & & & & & & & & & 1 \\
\hline obj. 113 & 9 & 1 & & 4 & 1 & & 2 & & 3 & & 1 & & & & & & & & & & 1 & & 3 & & 4 & & & \\
\hline obj. 128 & 5 & 1 & 5 & 7 & 1 & & 1 & & & & 13 & 8 & 1 & 2 & 2 & 1 & & & 3 & & & & 5 & & 1 & 1 & & 3 \\
\hline obj. 129 & 1 & & 1 & 4 & & & & & & & 2 & & & 1 & 1 & 1 & & & & & & & 1 & & 1 & & & 1 \\
\hline
\end{tabular}

Tab. 11. Kvantifikácia typov výzdoby pre horizont RS3.

Tab. 11. Quantification of types of decorations for horizon RS3.
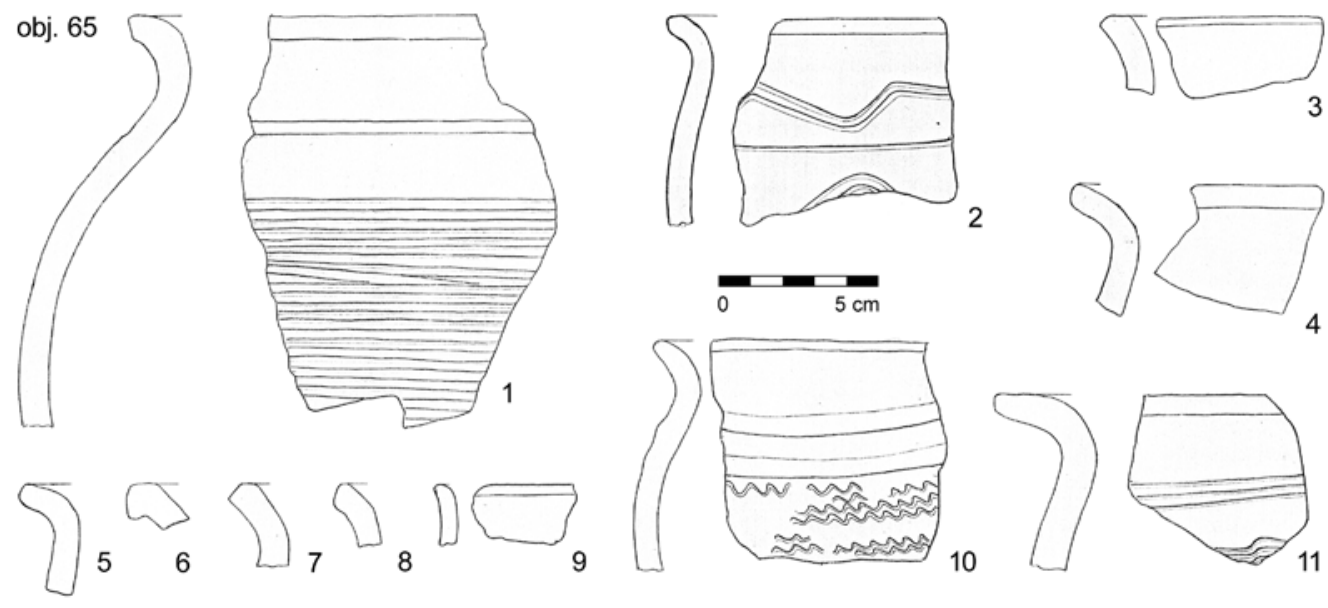

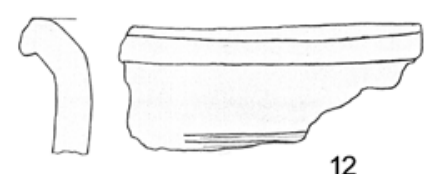

12

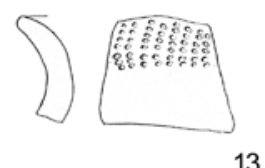

13
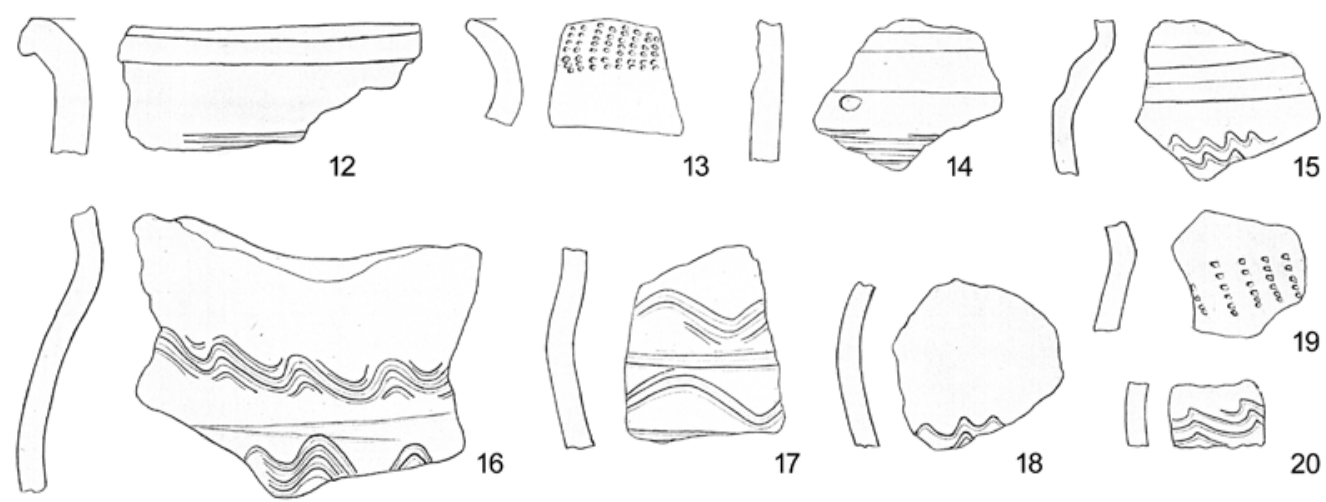
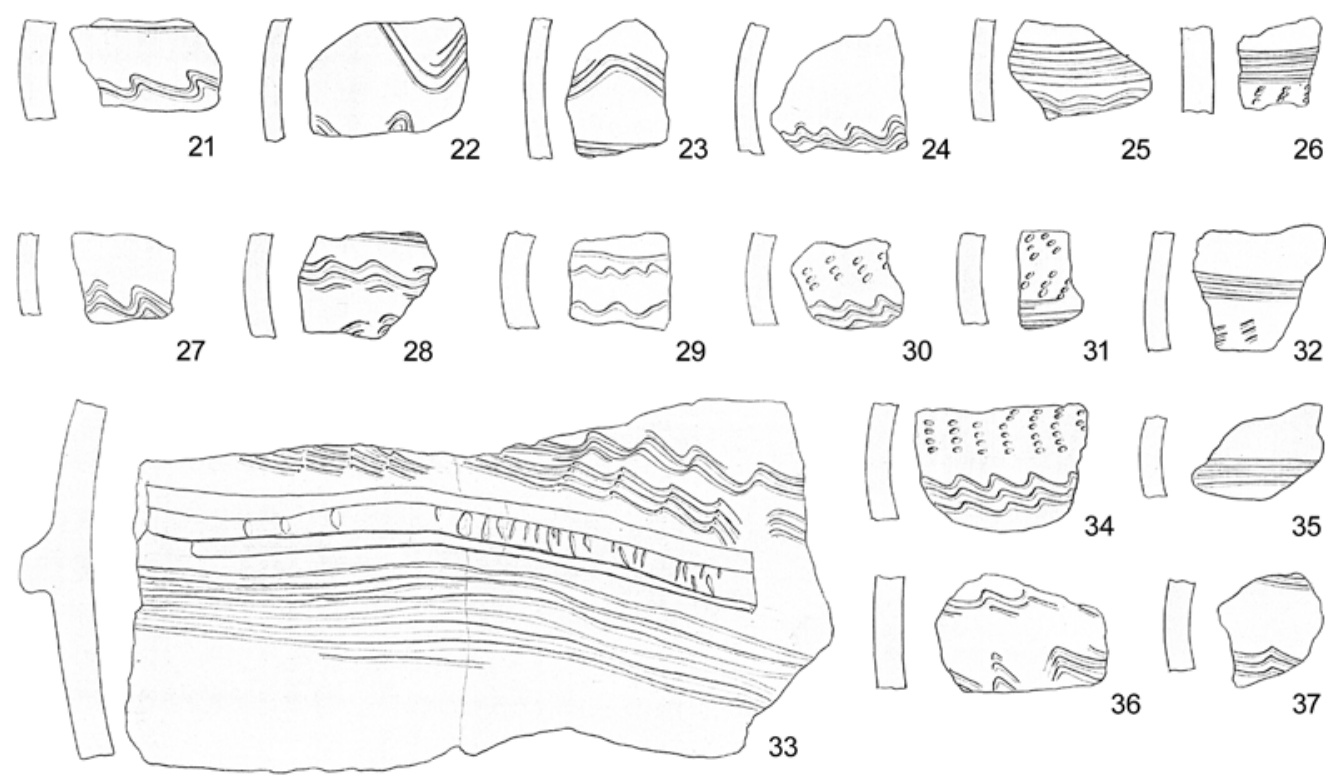

Obr. 26. Výber keramiky z objektu 65. Podl'a Geisler 1992, obr. 99-105.

Fig. 26. Selection of pottery from feature 65. After Geisler 1992 Fig. 99-105. 


\begin{tabular}{|c|c|c|c|c|c|c|c|c|}
\hline Okraje & A1 & A2 & B1 & B2 & B3 & B4 & C3 & D1 \\
\hline obj. 19 & & 1 & 5 & 1 & & & 2 & \\
\hline obj. 30 & 2 & & 4 & & & & & \\
\hline obj. 44 & 6 & 2 & 7 & & & & & \\
\hline obj. 65 & 8 & & 6 & 1 & & & & \\
\hline obj. 84 & & 1 & 2 & & & & & \\
\hline obj. 113 & 2 & & 4 & & 3 & & & \\
\hline obj. 128 & & 3 & 5 & 1 & & 2 & & 1 \\
\hline obj. 129 & & 4 & 3 & 2 & & & & \\
\hline
\end{tabular}

Tab. 12. Kvantifikácia okrajov pre horizont RS3.

Tab. 12. Quantification of rims for horizon RS3.

obj. 113
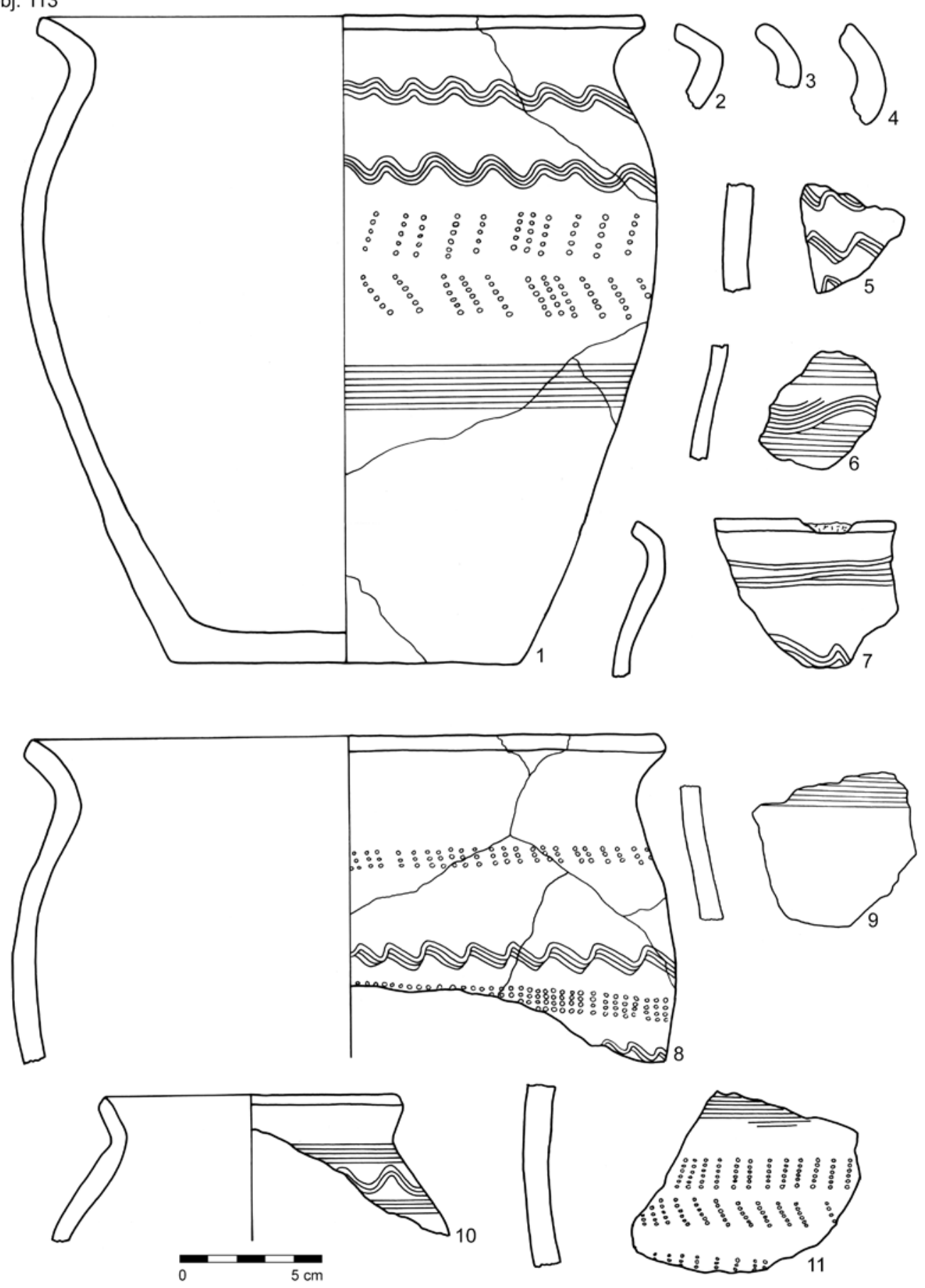

Obr. 27. Výber keramiky z objektu 113. Kresba J. Benech.

Fig. 27. Selection of pottery from feature 113. Drawing by J. Benech. 
Preto bol aj napriek prevahe hrebeňovitej výzdoby (30 kusov, 51 \%) iba jedného kusu zdobeného rytou výzdobou jednozubým nástrojom a jedného nedatovatel'ného, zaradeného do RS3. Nachádzala sa tu tiež lišta stredohradištného obdobia s lichobežníkovým profilom (obr. 26: 33). Do horizontu RS3 bol zaradený obj. 84. Výraznejšie kusy majú prehnutejšie okraje. Aj ked' prevláda hrebeňová výzdoba (sedem kusov, asi $58 \%$ ), vyskytujú sa aj pokročilé motívy. Obj. 113 bol ako jediný datovaný primárne vd’aka stratigrafii s obj. 128 (obr. 4). Objekt 128 je datovaný do RS3 a obj. 113 je očividne mladší aj napriek tomu, že prevažuje hrebeňová výzdoba (21 kusov, zhruba $39 \%$ ) a hrebeňové vpichy (sedem kusov, približne $13 \%)$. Výzdoba tvorená jednozubým nástrojom je zastúpená len jedným kusom. Objekt však obsahuje vel'ké pokročilejšie kusy (obr. 27: 1, 2, 7, 8, 10). Zároveň sa v objekte našla jediná nádoba na lokalite, ktorú bolo z fragmentov možné poskladat celú. Rovnako tu teda sledujeme sekundárny odpad (Kuna 2015, 282). Chatu 128 je aj vd'aka zásobnici 113 možné datovat do strednej doby hradištnej. Napriek typickej prevahe hrebeňovitej výzdoby (33 kusov, 33 \%) je tu väčšie množstvo rytej jednozubej výzdoby očividné (17 kusov, $17 \%$ ). Výzdoba vpichmi tvorí 7 \% (obr. 30: 3, 14-17, 19, 20, 21, 25). Posledný objekt datovaný do horizontu RS3 je obj. 129. Výzdoba tvorená jednozubým nástrojom tvorí 4 \% (3 kusy), výzdoba vpichmi $3 \%$ (2 kusy) a hrebeňová asi $11 \%$. Nachádzajú sa tu však dva kusy derivátu blučinského okruhu (obr. 25: 16, 19). obj. 24

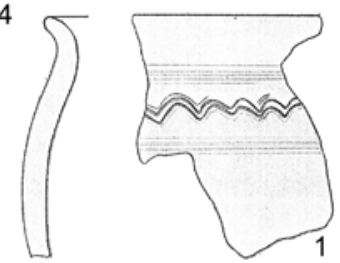

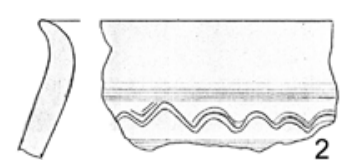
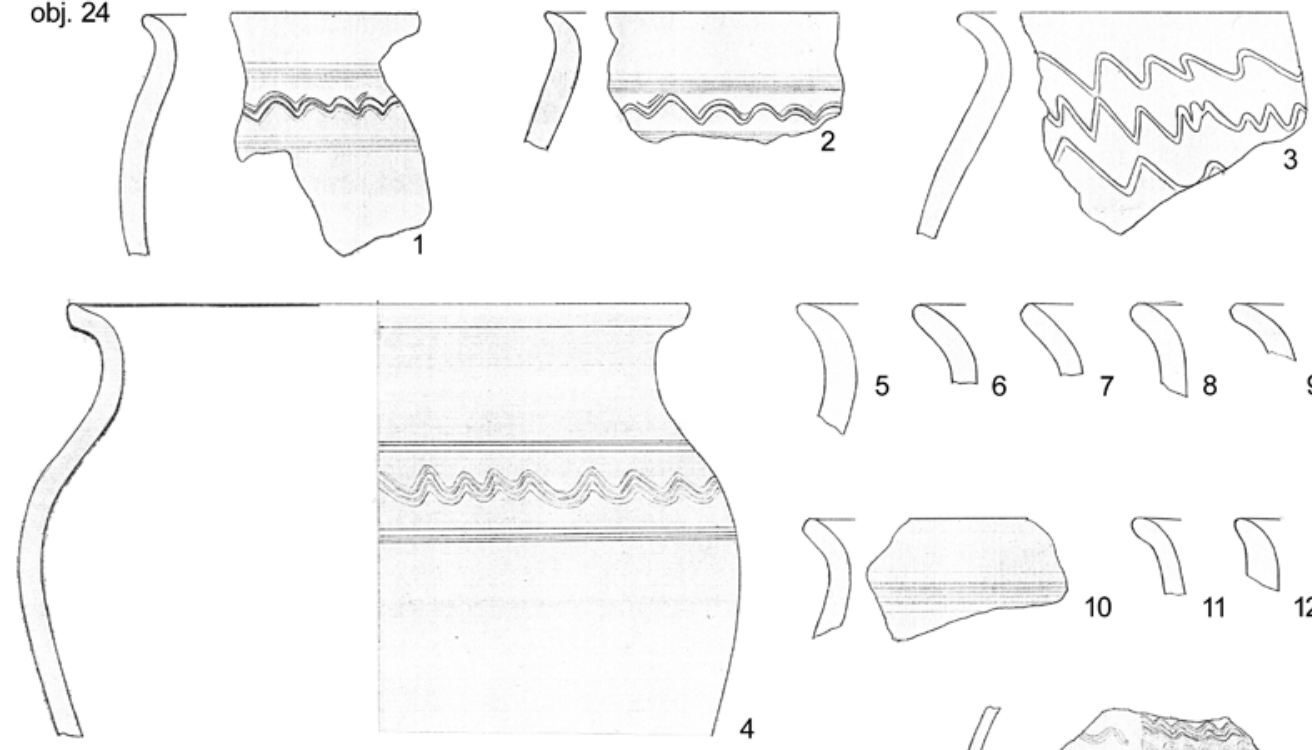

5
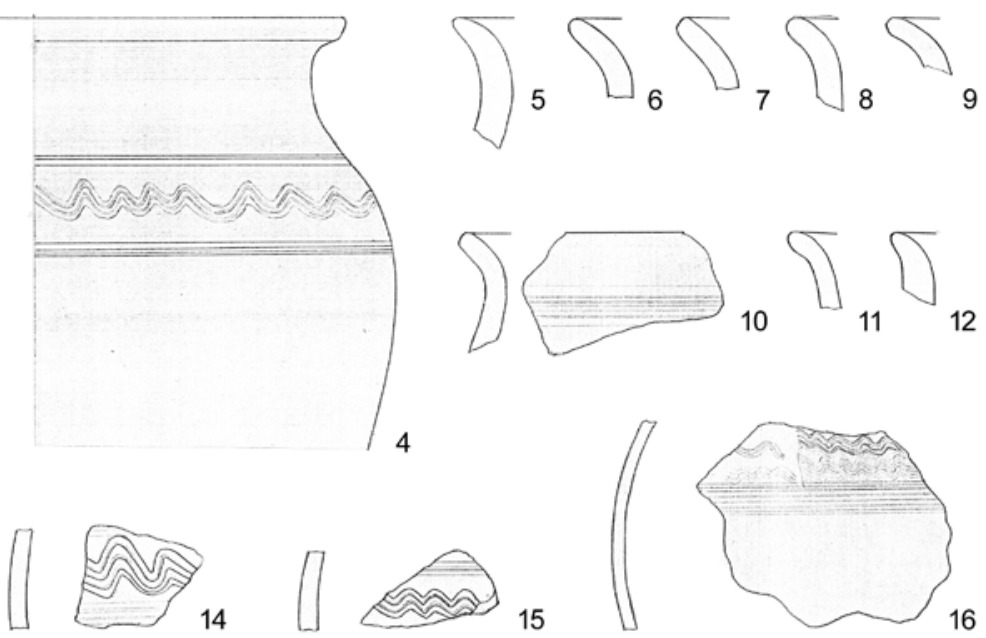

14

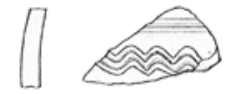

15

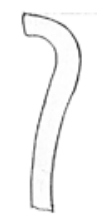

18

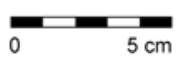

17

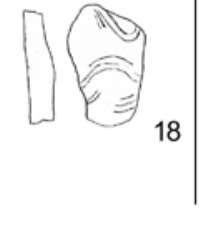

obj. 30

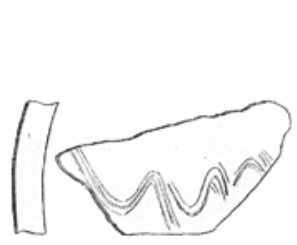

25

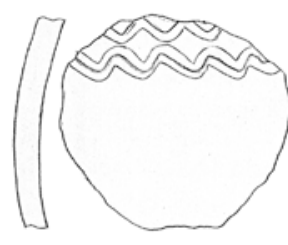

26

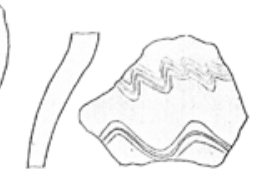

27

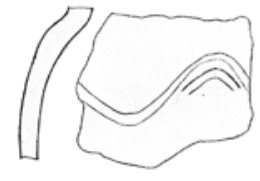

28

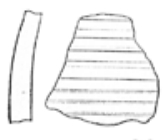

29
Obr. 28. Výber keramiky z objektov 24, 25, 30. Podl'a Geisler 1992 obr. 81-86.

Fig. 28. Selection of pottery from features 24, 25, 30. After Geisler 1992, Fig. 81-86. 
V rámci keramického materiálu zo sídliska v Brne-Medlánkach bol objavený zaujímavý jav, a to deriváty keramiky blučinského výrobného okruhu (obr. 22: 9; 25: 16, 19; 29: 6, 20). Nachádzali sa v obj. 19, 79 a 129. Tvoria jednu z malých, ale významných častí tretieho horizontu keramiky. Tieto rôzne napodobeniny sa v regióne Brnenska objavujú nezriedka. Okrem nami skúmaného sídliska sa deriváty vo vel'kých množstvách nachádzajú aj v Starých Zámkoch u Líšně (Staňa 1994, 271, obr. 6), kde tvoria tretí vel'komoravský horizont. Nie je však isté, či sa tam aj vyrábali. Takisto sa rôzne kusy nachádzali v Brnenských Ivanoviciach a Holáskách (Procházka et al. 2011, 493, obr. 208). Tieto nálezy indikujú možné kontakty, a teda aj vplyvy z regionálneho centra Staré Zámky u Líšně, ktoré vzhl'adom k svojej povahe mohlo byt šíritel’om trendov v oblasti Brnenska.

Vel'mi zaujímavý bol črep z obj. 65 (obr. 26: 10). Jeho profilované hrdlo a rytá výzdoba pozoruhodne pripomína dolnověstonickú keramiku. Rovnako zaoblený okraj je typický pre túto skupinu keramiky. Profilácia v hornej časti nádoby vôbec nie je výrazná, čo je vidiet’ aj na kusoch priamo z Dolních Věstonic (Ungerman 2007, 190-193). Nakol'ko je tento okruh charakteristický úzkym regionálnym výskytom, je pravdepodobnejšie, že ide o nádoby z vývalkami na pleciach, ktoré sú datované do 9. storočia. Podstatná odlišnosť od dolnověstonického okruhu spočíva hlavne v pestrosti výzdoby (kombinácie vlníc, vpichov či odtlačkov) a pestrejšej škále okrajov. Prípadný nadregionálny kontakt

obj. 19
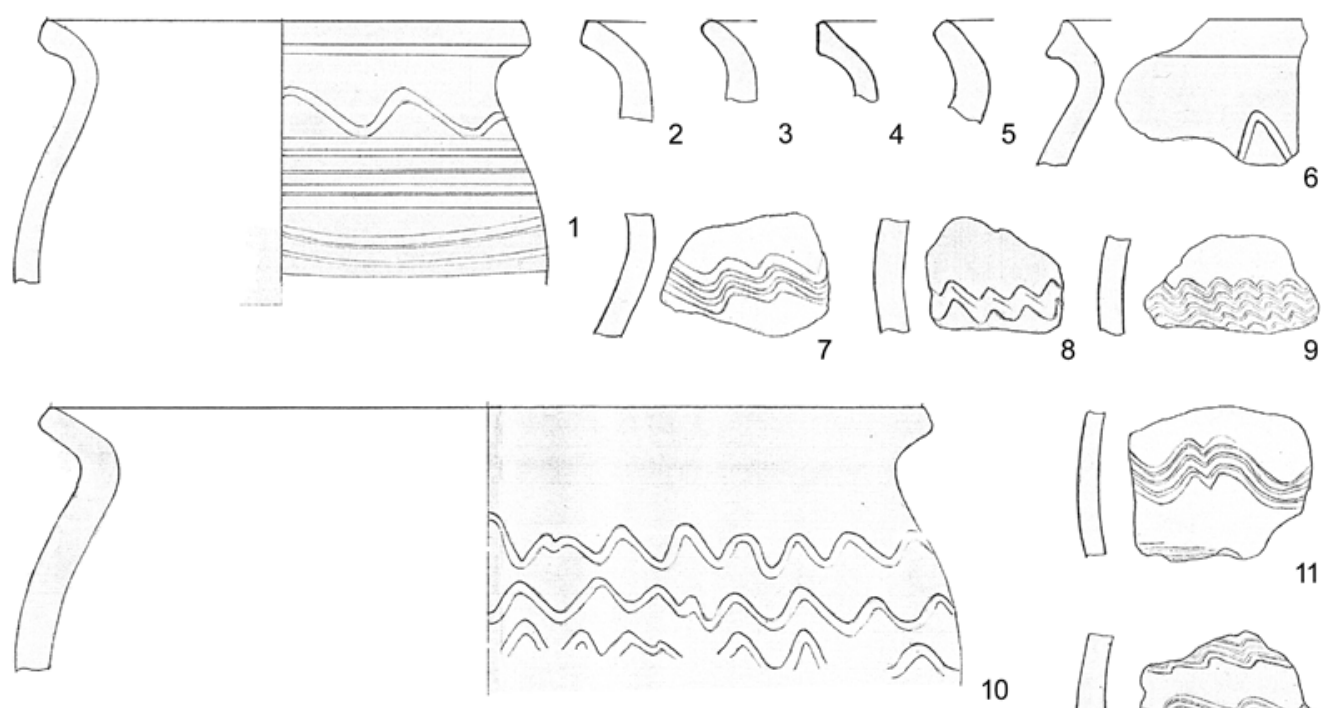
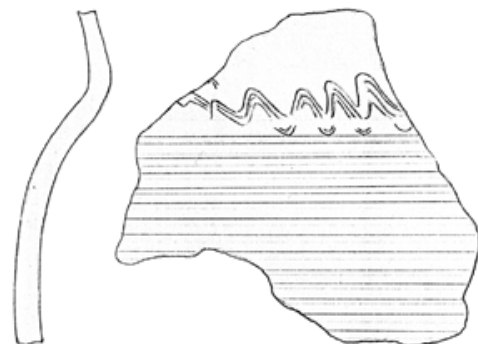

13
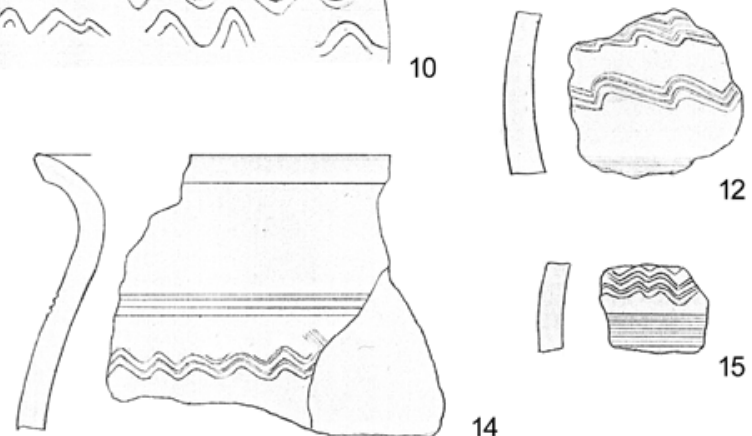

12

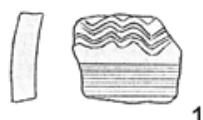

15
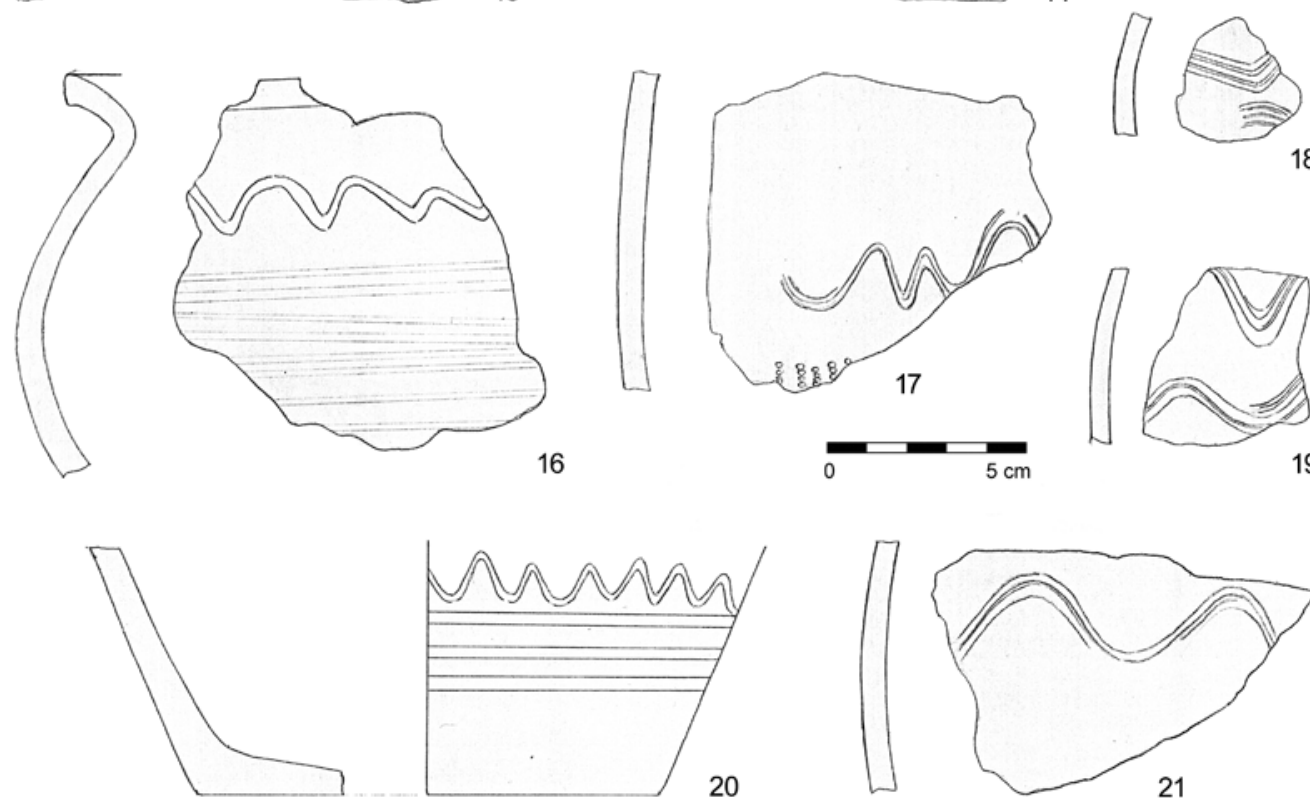

18

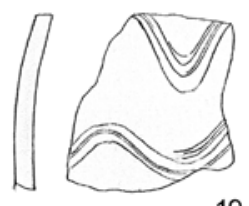

19
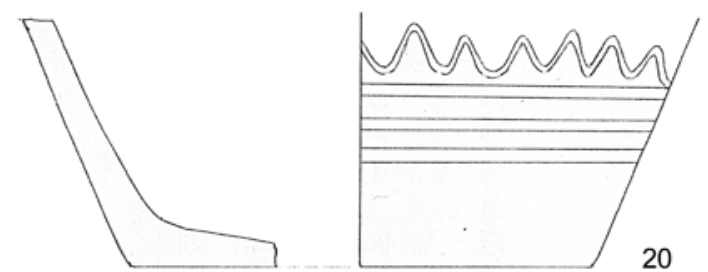

Obr. 29. Výber keramiky z objektu 19. Podl'a Geisler 1992, obr. 76-79. Fig. 29. Selection of pottery from feature 19. After Geisler 1992, Fig. 76-79. 
či snahu „napodobnit videné“ nie je možné úplne vylúčit?. Na základe charakteru posledného horizontu by sa dal zánik sídliska v Medlánkach datovat na koniec 9. storočia alebo do 10. storočia.

Horizont RS3 sa dá porovnat’ s materiálom zo Starých Zámkov. Synchronizácia 3. horizontu hradiska a medláneckého horizontu RS3 je trochu problematická. Časovo spolu síce súvisia, avšak samotné zloženie je odlišné. Zatial' čo v Medlánkach tento horizont tvoria nádoby s konzervatívnou výzdobou (častý hrebeňovitý vpich, prítomnost' hrebeňových vlnoviek, malá škála okrajov) v Starých Zámkoch prevažuje typická stredohradištná keramika s vysokým podielom blučinských derivátov a o niečo väčším zastúpením vyvinutých okrajov. Hrebeňové vlnovky a vpichy pomaly miznú. Častejšie môžeme pozorovat lišty aj výrazné odsadenia hrdla (Staňa 1994, 271, obr. 6; 2010, tab. 21: 1, 2; 22: 1, 2, 11;32: 3, 21). Je to spôsobené odlišným charakterom hmotnej kultúry hradísk, ktoré sa oproti vidieckym osadám prejavilo výrazne práve vo vel'komoravskom období. Zaujímavé je aj porovnanie súboru z Medlánok s materiálom zo sídliska v Kuřimi. Stredohradištná fáza zdiel’a malú škálu okrajov (avšak rovnako ako v Medlánkach aj tu bol nájdený výrazný výskyt kužel’ovito zrezaných typov) či hrebeňovitú výzdobu, ktorá je vel'mi nepravidelná (Procházka 1992, 334, obr. 3; 335, obr. 4; 337, obr. 6). Rytá výzdoba jednozubým nástrojom sa vyskytuje iba minimálne a aj to skôr až v mladohradištnej fázy. Blučinský obj. 113

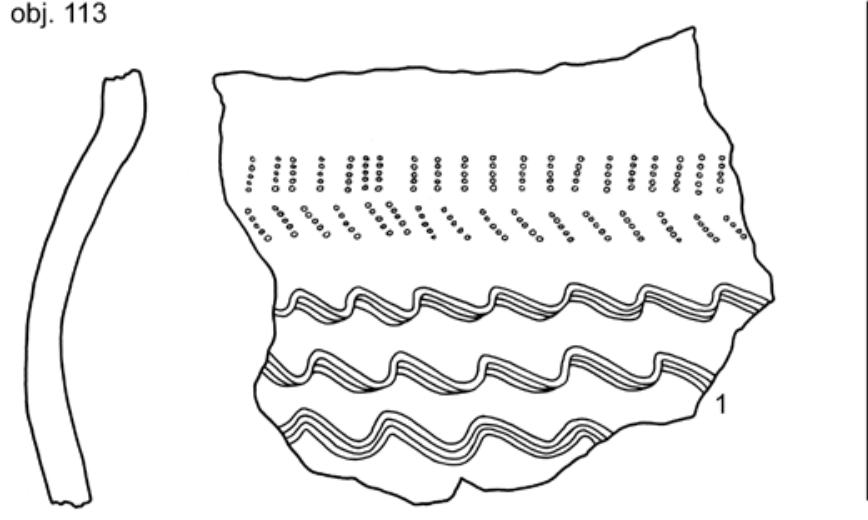

\section{obj. 128}
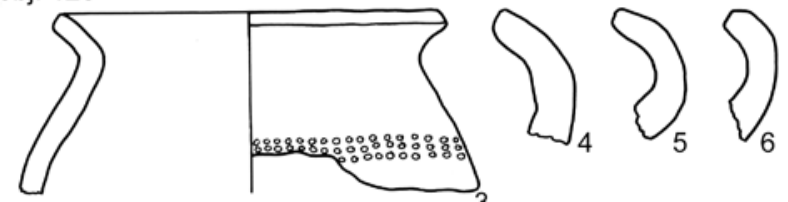
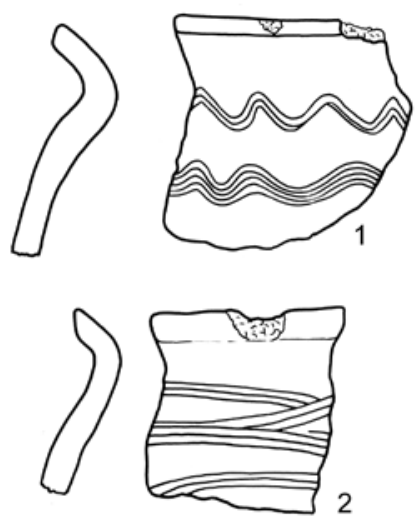

2
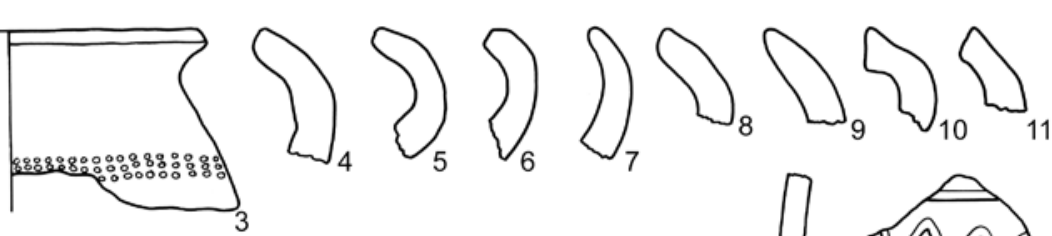

$\iint_{7}$
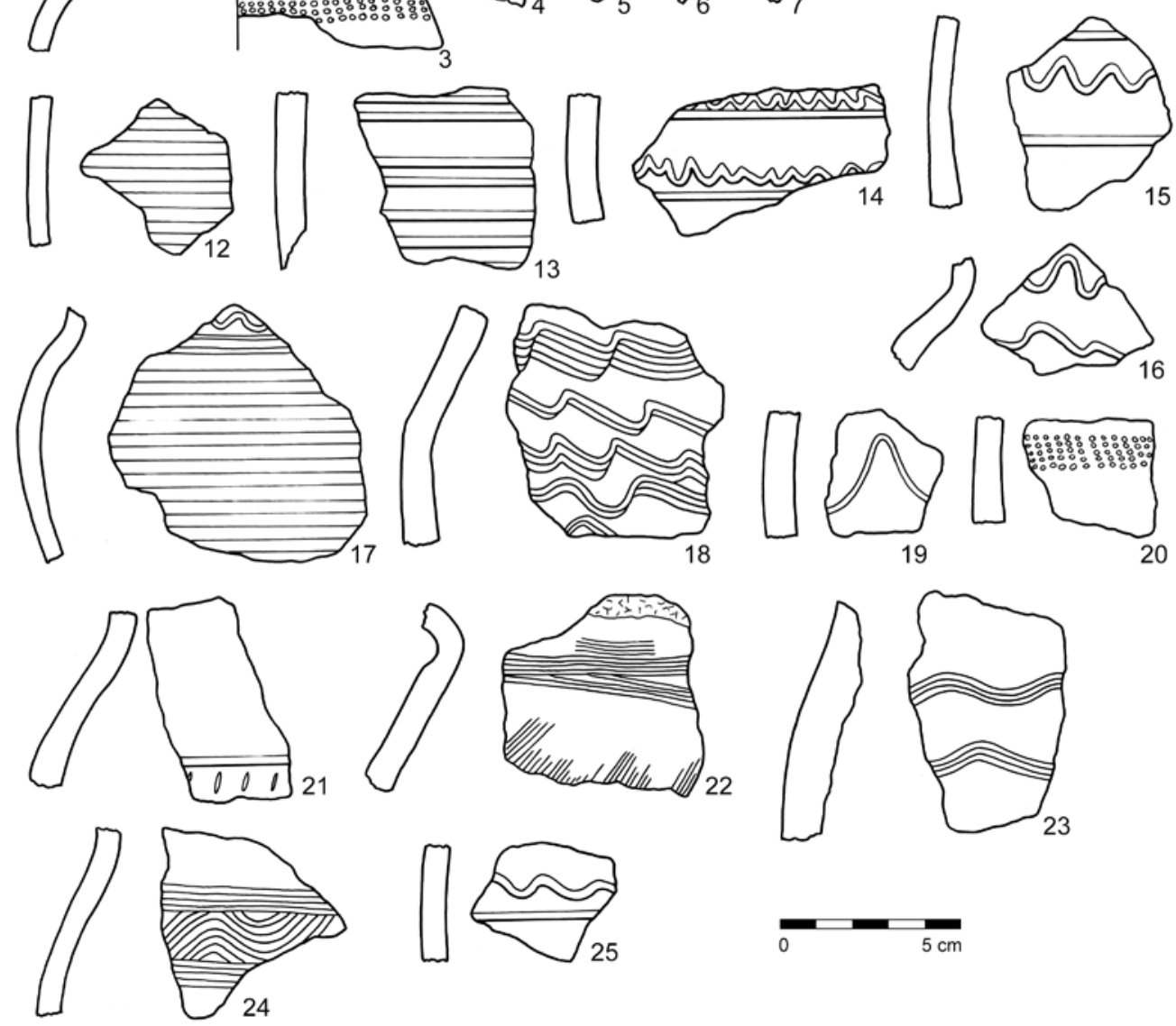

Obr. 30. Výber keramiky z objektov 113, 128. Kresba J. Benech.

Fig. 30. Selection of pottery from features 113, 128. Drawing by J. Benech. 


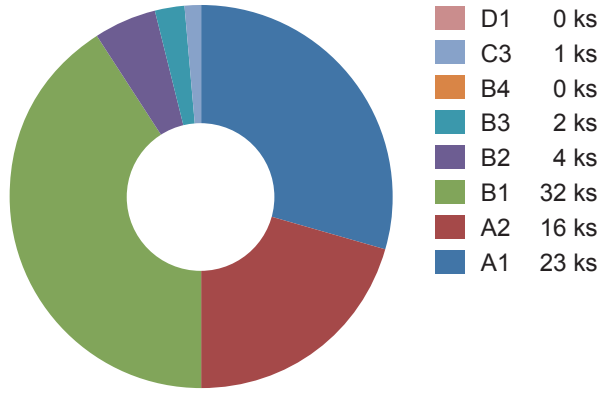

Graf 2. Zastúpenie typov ukončení okrajov v RS2(2).

Graph 2. Representation of types of rim finishing in RS2(2).

\begin{tabular}{lrrrrrrrr}
\hline Typ ukončenia okraja & A1 & A2 & B1 & B2 & B3 & B4 & C3 & D1 \\
\hline RS2(2) & 23 & 16 & 32 & 4 & 2 & 0 & 1 & 0 \\
\hline RS3 & 18 & 11 & 35 & 5 & 3 & 2 & 2 & 1 \\
\hline
\end{tabular}

výrobný okruh zachytený nebol. Podobná situácia je aj na hutníckom sídlisku v Olomoučanoch, kde sa ale hrebeňová výzdoba zdá byt pravidelnejšia a je zaznamenaný derivát nádoby blučinského okruhu (Souchopová 1986, 34-36, obr. 15-17).

Určenie odpadovej povahy keramických súborov, ako ich formuloval M. Kuna (2015, 280-287), bolo kvôli skartácii, zväčša malému počtu jedincov a minimálnemu výskytu vel'kých fragmentov, problematické. Primárny odpad sa na lokalite rozlíšit nepodarilo. Presvedčivo sa sekundárne odkladanie odpadu potvrdilo len v obj. 44 (obr. 21: 1-8) a 113 (obr. 27: 1, 8). Uvažovat̉ o sekundárnom odkladaní môžeme aj v obj. 7 (obr. 13: 1, 2), 19 (obr. 29: 1, 10), 24 (obr. 28: 4) a 112 (obr. 11: 11), kde však šlo skôr iba o jednotlivé kusy. Môžeme predpokladat, že vzhl'adom k vel'kému počtu drobných a odlišných kusov keramiky v objektoch tvoril väčšinu súborov terciálny odpad, splavený do objektov z okolitých kultúrnych vrstiev.

Keramický materiál z Brna-Medlánok vo všeobecnosti nesie niekol'ko špecifík naznačených už v kvantifikácií datovaných objektov. Jednou z nich je už spomínaný konzervatívny prístup k výrobe a výzdobe, ktorý je okrem dlhodobého používania výzdoby starohradištného obdobia viditel'ný aj na prevládajúcom spôsobe výroby, s ním spojeným používaným materiálom, či tvare okrajov. Všetky javy boli sledované v rámci jednotlivých horizontov relatívneho datovania. Nakol'ko sa v jednotlivých objektoch nachádzal vel'ký počet prímesí, nebude toto vyhodnotenie úplne presné. Pre lepší prehl’ad a zväčšenie výpovednej hodnoty diagramov je pod každým tabul'ka dát, z ktorej vychádza. V prípade ukončenia okraja však horizont RS1 nemá vlastný diagram, nakol'ko okraje z objektu 93 boli stratené, a teda nie sú v databáze.

Diagramy a tabul'ka dát (graf 2, 3, tab. 13) jasne ukazujú spomínanú homogenitu na palete typov okrajov, pričom prevládajú typy A1, A2 a B1, teda zaoblený, zaoblený zužujúci sa a jednoducho zrezaný valcovito/kuželovito. Tieto sa používajú naprieč horizontmi RS2 aj RS3. V horizonte RS1 sa nachádzal iba typ A1. Ostatné typy okrajov (B2 zrezaný valcovito/kužel'ovito s vytiahnutou spodnou hranou, B3 zrezaný valcovito/ kužel'ovito s vytiahnutou hornou hranou, C3 lievikovito zrezaný s vytiahnutou hornou hranou a D1 jednoduchý vodorovne zrezaný) boli používané len zriedka, a to takmer výlučne na keramike stredohradištného obdobia, resp. v rámci tretieho horizontu. V prípade objektov datovaných do fázy RS2(2) (graf 2) je

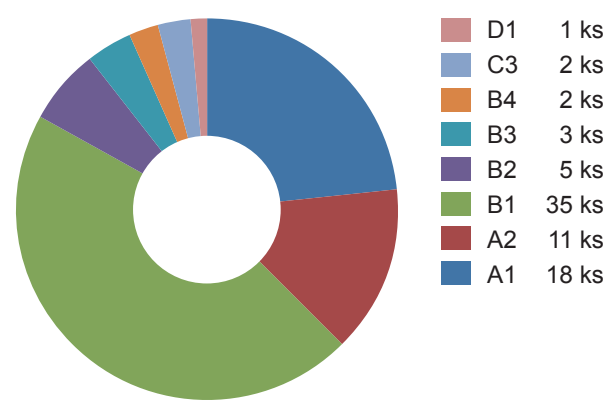

Graf 3. Zastúpenie typov ukončení okrajov v RS3.

Graph 3. Representation of types of rim finishing in RS3.

Tab. 13. Zastúpenie typov okrajov vo vzorkách RS3 a RS2(2)

Tab. 13. Representation of rim types in the samples for RS3 and RS2(2).

pomer okrajov A1, A2 a B1 vyrovnanejší, avšak B1 prevláda. Paleta okrajov končí typom B3, ktorý je v skupine pravdepodobne stredohradištnou prímesou. Na horizonte RS3 (graf 3) je najviac viditel'ný zaostalejší prístup k výrobe. Jednoduché okraje prevažujú s predošlou tendenciou. Na ústupe sú zaoblené okraje (A1, A2) a v malom počte figuruje okraj C3 a D1. Vzhl'adom k pomeru starohradištných a stredohradištných okrajov je možné predpokladat', že stredohradištné okraje boli roztrúsené ako intrúzia a nie opačne. Ked’že v rámci výskumu objektov neboli nájdené žiadne vrstvy, bude tento predpoklad stále sporný.

Spôsob výroby v prvom horizonte je zastúpený modelovaním v ruke (graf 4, tab. 14). To sa objavuje aj v mladších horizontoch RS2(2) a RS3 ako intrúzia „spadnutá“ do objektov z kultúrnej vrstvy, v rámci postdepozičných procesov. Malý počet nádob vyhotovených silno formujúcim obtáčaním objavujúcich sa vo fáze RS2(2) a horizonte RS3 je, ak nie dokladom postupného a pomalého prenikania vyspelejších technológií na „vidiek“, snád’ kontaktom s regionálnym centrom, $\mathrm{v}$ tomto prípade s líšenským hradiskom. Znova je tu možné pozorovat vplyv vidieckeho prostredia na výrobu. V druhom horizonte (graf 5) je typická výrazná prevaha slabo formujúceho obtáčania. $V$ tret’om horizonte je tendencia rovnaká ako v prípade horizontu druhého, čo len dokazuje spomínanú technologickú zaostalosṫ (graf 6). Množstvo nádob vyhotovených silne formujúcim obtáčaním je v porovnaní s RS2(2) o niečo väčší. Taktiež vel'ký počet kusov nebolo možné technologicky určit', čo tiež presnost výsledkov výrazne skresl'uje. Diagramy spôsobu výroby ukazujú, že drvivá väčšina jedincov bola vyrobená slabo formujúcim obtáčaním. Tento spôsob je charakteristický nielen pre starú dobu hradištnú, ale aj pre podomácku malovýrobu v rámci mladších období.

Zastúpenie keramickej hmoty a kvalita výpalu len potvrdzujú predošlé tvrdenia o povahe hrnčiarskej výroby na sídlisku v Brne-Medlánkach (tab. 15). Absolútnu prevahu má hrubý zle vypálený materiál s malým počtom hrubého dobre vypáleného materiálu. Super hrubý zle vypálený materiál reprezentuje pražský typ (graf 7). Jemný materiál sa objavuje v minimálnom počte. Táto tendencia je pre všetky horizonty rovnaká (graf 7-9). V druhom aj tretom horizonte (graf 8, 9) sa v malom množstve objavuje materiál super hrubý zle vypálený a jemný zle vypálený, čo je v druhom horizonte určite spôsobené intrúziou. V tretom horizonte je výskyt jemného zle vypáleného materiálu očakávaný. 


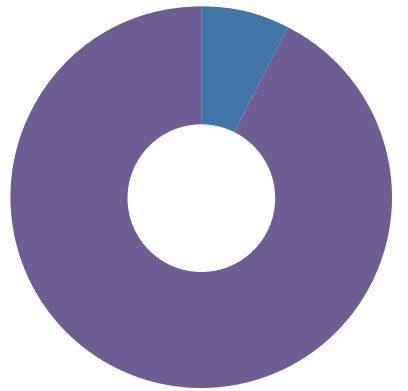

v ruke

obtáčanie slabo formujúce

obtáčanie silno formujúce

nesledované
$2 \mathrm{ks}$

$0 \mathrm{ks}$

$0 \mathrm{ks}$ $1 \mathrm{ks}$

Graf 4. Spôsob výroby v RS1.

Graph 4. Production method in RS1.

\begin{tabular}{lrrrr}
\hline Technológia & Nesledované & $\begin{array}{r}\text { Obtáčanie silno } \\
\text { formujúce }\end{array}$ & $\begin{array}{r}\text { Obtáčanie slabo } \\
\text { formujúce }\end{array}$ & V ruke \\
\hline RS1 & 1 & 0 & 0 & 12 \\
\hline RS2(2) & 118 & 13 & 173 & 7 \\
\hline RS3 & 127 & 18 & 197 & 14 \\
\hline
\end{tabular}

Tab. 14. Zastúpenie spôsobu výroby vo vzorkách pre RS1, RS2(2) a RS3. Tab. 14. Representation of production methods in the samples for RS1, RS2(2) and RS3.

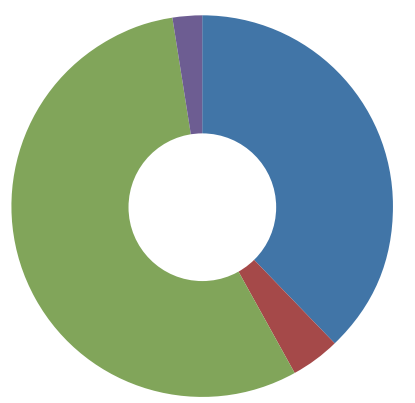

v ruke

obtáčanie slabo formujúce 173 ks obtáčanie silno formujúce 13 ks nesledované $118 \mathrm{ks}$

Graf 5. Spôsob výroby v RS2(2)

Graph 5. Production method in RS2(2).

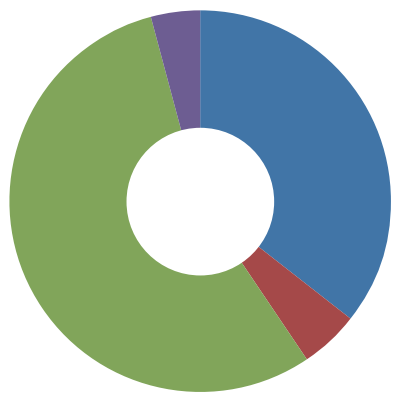

v ruke obtáčanie slabo formujúce 197 ks obtáčanie silno formujúce $18 \mathrm{ks}$ nesledované $127 \mathrm{ks}$

Graf 6. Spôsob výroby v RS3.

Graph 6. Production method in RS3.

\begin{tabular}{lrrrrr}
\hline Materiál & I(HDV) & I(HZV) & I(super HDV) & I(super HZV) & II(JZV) \\
\hline RS1 & 0 & 1 & 0 & 12 & 0 \\
\hline RS2(2) & 3 & 283 & 10 & 12 & 4 \\
\hline RS3 & 18 & 366 & 0 & 14 & 5 \\
\hline
\end{tabular}

Tab. 15. Zastúpenie typov materiálov vo vzorkách pre RS1, RS2(2) a RS3.

Tab. 15. Representation of types of material in the samples for RS1, RS2(2) and RS3.

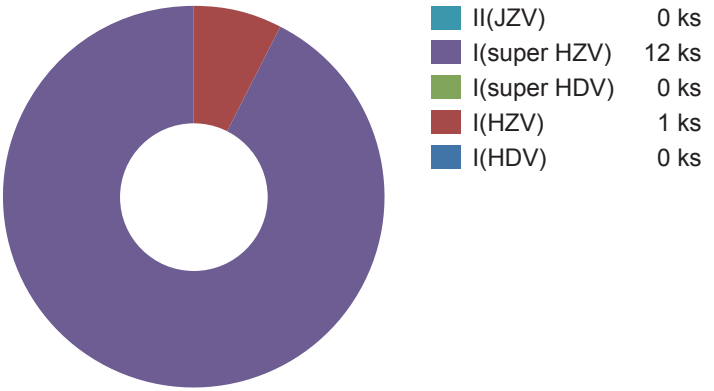

Graf 7. Keramická hmota a kvalita výpalu RS1.

Graph 7. Ceramic material and quality of firing RS1.

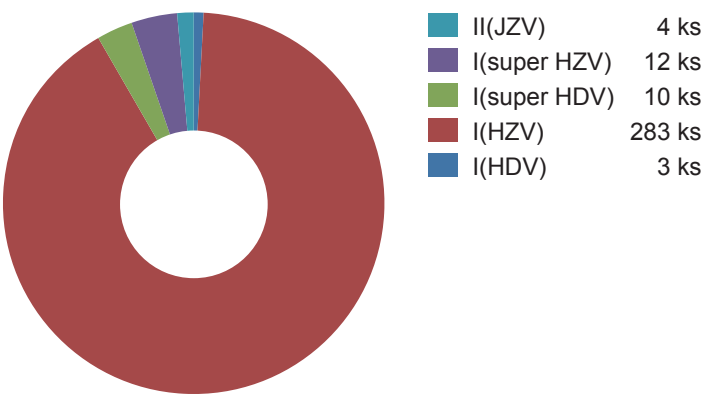

Graf 8. Keramická hmota a kvalita výpalu RS2(2).

Graph 8. Ceramic material and quality of firing RS2(2).

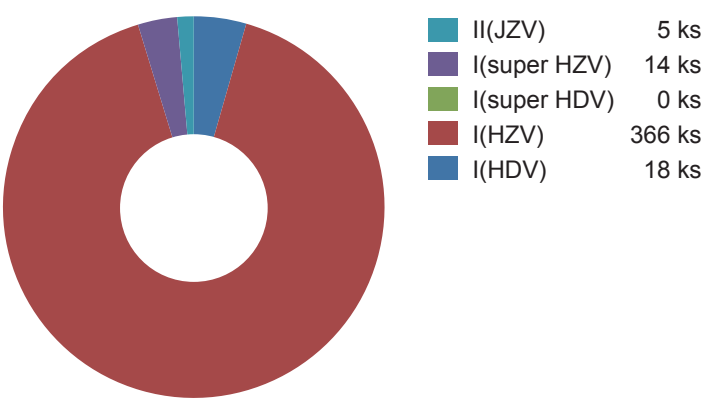

Graf 9. Keramická hmota a kvalita výpalu RS3.

Graph 9. Ceramic material and quality of firing RS3.

\begin{tabular}{lrr}
\hline Sl'uda & Nie & Áno \\
RS1 & 13 & 0 \\
\hline RS2(2) & 253 & 59 \\
\hline RS3 & 291 & 119 \\
\hline
\end{tabular}

Tab. 16. Výskyt sl'udy vo vzorkách pre RS1, RS2(2) a RS3

Tab. 16. Occurrence of mica in the samples for RS1, RS2(2) and RS3.

Posledným výrazným javom, na ktorý je potrebné upozornit, je pozoruhodne vel'ká prítomnost' tzv. zlatej sl'udy v keramickom materiáli. Zlatá sl'uda je ostrivo s výrazným obsahom zvetraného zlatožltého biotitu. Obvykle sa vyskytuje spolu s muskovitom, ktorý sa javí ako striebristý (Gregerová 2010, 139). Táto prímes má v horizonte RS2 zastúpenie 23 \%a v RS3 sa zvyšuje až na $41 \%$. Kusy z horizontu RS1 túto prímes nemajú (tab. 16). Na podobný jav upozornila D. Zapletalová (Zapletalová 2001, 131-132), a to aj v prípade starohradištného sídliska Brno-Starý Lískovec. 


\section{Spoločenský rozmer sídliska}

Na sídlisku v Brne-Medlánkach boli sledované niektoré faktory, ktoré ilustrujú tamojšie spoločenské usporiadanie. Neboli odkryté žiadne väčšie sídelné objekty ani luxusná keramika. Dôležitý ukazovatel' je tiež neprítomnost honosnejších šperkov, zbraní či iných militárií, nakol'ko sa tieto typy nálezov nachádzajú takmer výlučne v prostredí pohrebísk. Žiadne pohrebisko v okolí lokality odkryté nebolo, a preto niet žiadnych dôkazov dokladajúcich prítomnost' elít a s nimi spojenej bojovníckej vrstvy. Na sídlisku sa našla depónia kostry, pravdepodobne jazdeckého koňa (pozri d’alej), čo môže indikovat' prítomnost’ ak nie bojovníka tak aspoň predáka, a to aj napriek tomu, že sa na sídlisku nenašli žiadne ostrohy. Absencia ostrôh môže byt spôsobená tým, že sa podobné nálezy v rámci vidieckeho prostredia vyskytujú skôr v prostredí pohrebísk a len vel'mi ojedinele v sídliskových objektoch. Túto tendenciu je možné vnímat aj pri porovnaní so sídliskom Dolní Kotvice-Sady. Aj napriek tomu, že sa sídlisko nachádzalo vel'mi blízko centra Staré Město u Uherského Hradiště bolo nálezovo omnoho honosnejšie než Medlánky (Marešová 1985, 57-88). Dokonca pri ňom bolo objavené aj pridružené pohrebisko s prítomnostou bojovníckej vrstvy. Na lokalite v sídliskovom prostredí sa našla iba jedna predvel'komoravská ostroha s háčikmi (Marešová 1985, 79-80).

Z drobných nekeramických predmetov boli v Brne-Medlánkach nájdené tri nožíky, dva zlomky hrebeňov a sklenený korálik. Nožíky ležali v obj. 79, 128 a jeden na povrchu (obr. 31: 1, 2). Na analýzu kovových predmetov bol použitý deskriptívny systém B. Dostála (Dostál 1975, 195-197, 206-210). Malý nožík z obj. 79 má čepel’ dlhú 9,8 cm a širokú $1,4 \mathrm{~cm}$. Je oblúkovito prehnutá k ostriu. Chrbát je rovný, na konci sa vel'mi nenápadne zbieha šikmo k ostriu. Na čepeli nie je prítomný odl’ahčovací výbrus, tŕň je tenký a dlhý $3,5 \mathrm{~cm}$. Nožík je zachovaný v celku. Druhý nožík (neinventarizovaný) bol nájdený v povrchovej vrstve. Jeho čepel' je dlhá len $5,4 \mathrm{~cm}$ a 1,4 cm široká. Chrbát sa po celej dížke šikmo zvažuje k ostriu, čepel' je k ostriu oblúkovito vyhnutá. Nožík sa zachoval celý a nie sú na ňom vidiet žiadne krvné ryhy. Tŕn je tenký, dlhý 2 cm. Tretí nožík bol nájdený v obj. 128, je však stratený.

Zaujímavým nálezom boli aj dva zlomky dvoch kostených hrebeňov (obr. 32: 2, 3) v obj. 19 a 35. Kostené hrebene sa na území Moravy objavujú nepretržite už od doby rímskej a zväčša ich nemožno samé o sebe označit za „slovanské“ alebo „germánske“ (Hrubý 1957, 165-166). Oba zlomky sú stredové doštičky, ktoré boli súčastou trojvrstvového obojstranného hrebeňa. Tie pozostávali z troch na seba „sendvičovo“ naukladaných doštičiek, ktorých stredová čast’ mala na oboch koncoch zuby rôznej dížky a hustoty, vyrezané až ku krycej lište. Dve dlhé krycie doštičky, ktoré držali stredové ozubené komponenty pokope z oboch strán, k nim boli pripevnené drobnými nitmi (Kavánová 1995, 211-212; Bartošková 2003, 254-255). Doštička z obj. 35 tvorila okrajový kus. Na zlomkoch z oboch objektov je viditel'ný otvor pre nit. Podl'a typológie E. Cnotliwého boli oba zlomky zaradené do skupiny II B 1. Tieto typy sa na včasnostredovekých sídliskách aj pohrebiskách vyskytujú bežne, ale sú tažko datovatel’né (Cnotliwy 1973, 84, 189-214; Bartošková 2003, 261; Váňa 1995, 61-62). Absencia obkladových doštičiek, ktoré sú charakteristicky často zdobené, neumožňuje zaradiť zlomky do širšieho kontextu v rámci strednej Európy.

\section{I}

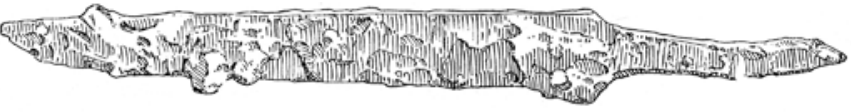

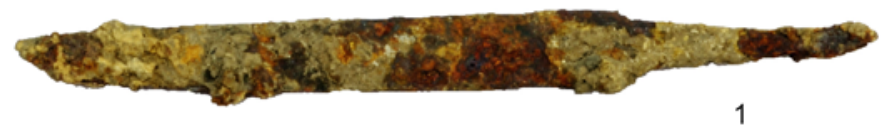
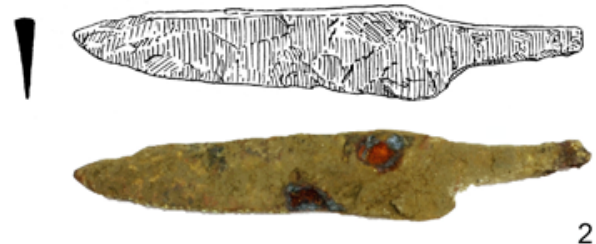

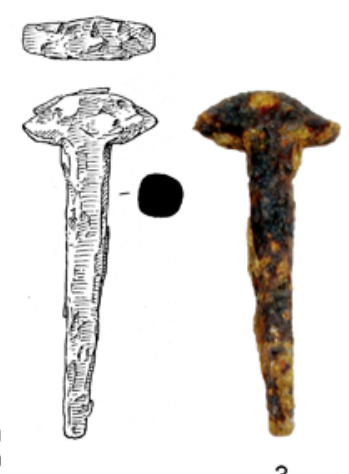

3
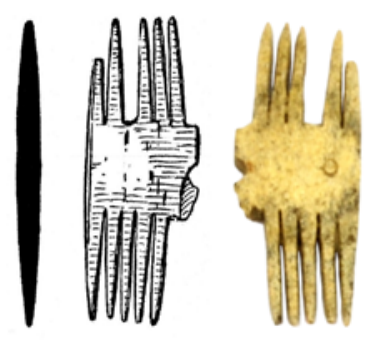

2
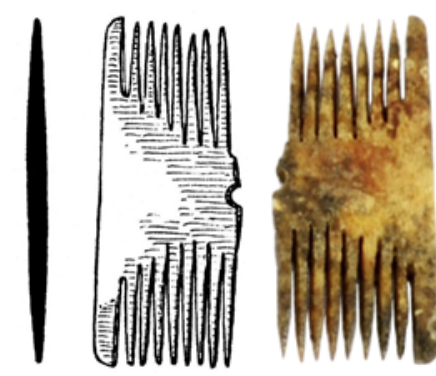

3

Obr.31. Kovové predmety. 1 - Nožík z objektu 79; 2 - nožík z povrchových vrstiev; 3 - železný klinec z objektu 5 . Kresba podl'a Geisler 1992, obr. 132; foto J. Benech.

Fig. 31. Metal objects. 1 - Knife from feature 79; 2 - knife from surface layer; 3 - iron nail from feature 5. Drawing after Geisler 1992, obr. 132; photo by J. Benech.
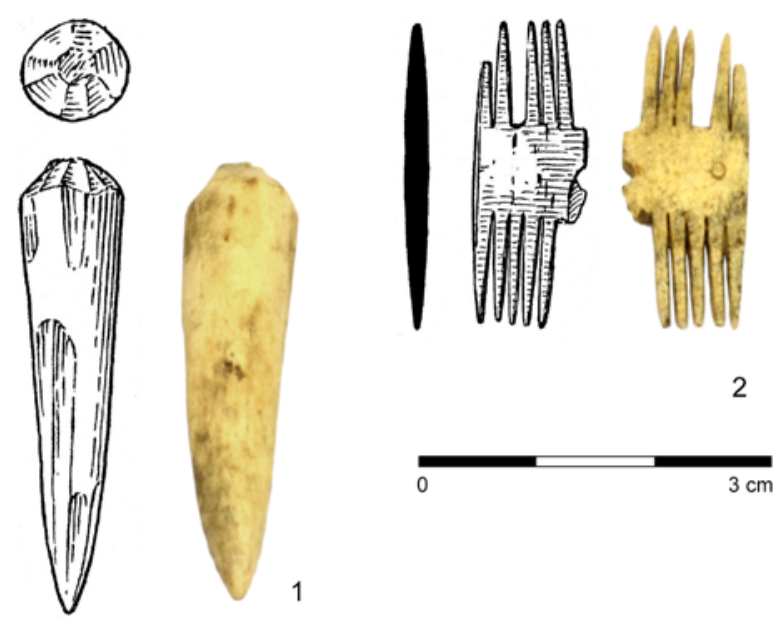

\footnotetext{
Obr. 32. Kostené predmety. 1 - Kostený hrot zobjektu 19, 2 - fragment trojvrstvového obojstranného hrebeňa z objektu 19; 3 - fragment trojvrstvového obojstranného hrebeňa z objektu 35. Kresba podl'a Geisler 1992, obr. 132; foto J. Benech. Fig. 32. Bone objects. 1 - Semifinished tip from feature 19; 2 - fragment of three-ply double-sided comb from feature 19; 3 - fragment of three-ply double-sided comb from feature 35. Drawing after Geisler 1992 Fig. 132; photo by J. Benech.
} 


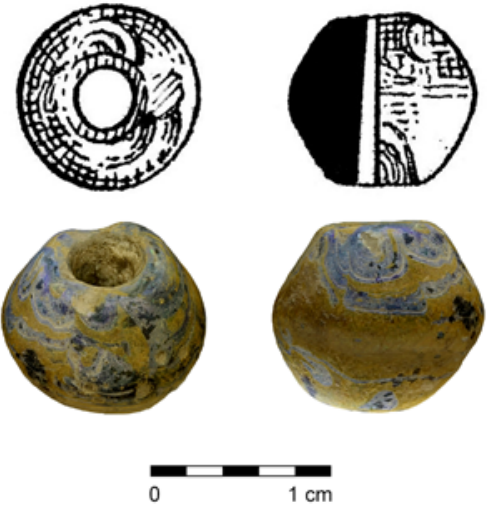

Obr. 33. Sklenený korálik z objektu 106. Kresba podl’a Geisler 1992, obr. 132; foto J. Benech.

Fig. 33. Glass bead from feature 106. Drawing after Geisler 1992, Fig. 132; photo by J. Benech.

Posledným nálezom bol jednoduchý sklenený korálik v zásobnici obj. 106 (obr. 33). Vzhl’adom k absencii stratigrafie objektu nejde určit, v ktorej časti a v akej híbke sa nachádzal. Korálik je vel'mi dobre zachovaný (výška 8,53 mm, šírka 10,14 mm). Je vyrobený zo žltého skla, na ktoré bola zatavenou tmavomodrou nitou aplikovaná výzdoba (nesie stopy korózie) a má bikónický tvar. Nenesie stopy kovovej fólie ani kovovej trubičky v otvore. Z. Krumphanzlová tieto typy opisuje ako koráliky jednofarebné, jednoduché, hranolovité (Krumphanzlová 1965, 171-172). Išlo pravdepodobne o stratený kus z pretrhnutého náhrdelníka, ked’že celé súbory korálikov (ale aj jednotlivé kusy) sú skôr súčastou hrobových výbav žien a detí prevažne v priebehu 9. a 10. storočia (Staššíková-Štukovská 2002, 47).

\section{Praktický rozmer sídliska - výrobné aktivity a ich priestorová štruktúra}

Slovanské sídlisko v Brne-Medlánkach je typickou včasnostredovekou lokalitou vidieckeho charakteru s kumulovanou štruktúrou osídlenia. Vd’aka keramickým nálezom je ho možné datovat od prelomu 6.-7. storočia do 10. storočia. Prítomnost’

\begin{tabular}{rllll} 
Č. obj. & Priemer & Čast & Typ & Hornina \\
\hline 86 & $43 \mathrm{~cm}$ & rotor & s papricou & svor \\
\hline 90 & $37 \mathrm{~cm}$ & ležiak & - & svorová rula \\
\hline 112 & $46 \mathrm{~cm}$ & rotor & - & svorová rula \\
\hline 114 & $44 \mathrm{~cm}$ & rotor & - & svorová rula \\
\hline
\end{tabular}

Tab. 17. Analýza žarnovov.

Tab. 17. Analyses of quernstones.

zásobníc dokladá prirodzene pol’nohospodársky charakter sídliska. Aj napriek absencii priamych dôkazov pol’nohospodárskej výroby (zvyšky orby či palynologický materiál) je táto činnost’ po všetkých stránkach samozrejmá. Zároveň v ňom bola najzásadnejšia a tvorila hlavný spôsob obživy obyvatel'ov. Rastlinnú výrobu nepriamo dokladajú aj žarnovy. Autorom petrografického určenia je A. Přichystal. Žarnovy sa vyrábali zväčša zo svoru. Z horniny bola vyrobená napr. väčšina žarnovov na lokalite Staré Zámky u Líšně (Ondráček, Přichystal 2017, 141-146; Přichystal 2009, 239). V Brne-Medlánkach boli nájdené štyri celé žarnovy (obr. 34, tab. 17). Kusy z obj. 90, 112 a 114 boli vyrobené z dvojsl'udnej svorovej ruly s obsahom turmalínu (skorylu), čo sa zhoduje aj so situáciou v spomínaných Starých Zámkoch u Líšně. Pôvod materiálu je moravský (Přichystal 2009, 230-231) a je ho možné hl'adat na lokalite Čučice u Oslavan, juhozápadne od Brna, kde sa hornina tažila a odkial' sa distribuovala (Přichystal 2009, 239-240). Žarnov z obj. 86 bol vyrobený zo svoru s červeným granátom. Ten sa ako materiál na žarnovy hojne vyskytol napríklad v Znojme. Pôvod tejto horniny nie je istý. Medzi pravdepodobné miesta pôvodu patrí lokalita Vranov nad Dyjí a tzv. Granátová zátoka (Šichnárková 2014, 52-53). Táto skutočnost je dokladom obchodu s týmito predmetmi. Ani žarnovy, ani ich zlomky neboli nájdené v rámci samotných chát. Tri z nich (vrátane zlomkov) sa nachádzali v zásobniciach, konkrétne v obj. 73, 106 a 112. Zlomky ležali v obj. 73, 95, 106 a 130. Táto skutočnosť môže naznačovat', že osada mohla byt’ opustená.

$\mathrm{V}$ zásobnici (obj. 87) bola taktiež nájdená pražnica (obr. 25: 2). Tá je silne fragmentarizovaná a jednotlivé mohutné kusy nie sú dosť početné na to, aby bolo možné rekonštruovat jej tvar a presné rozmery. Objavujú sa ale určité náznaky oválneho tvaru. Pražnica je silne prepálená, jej vnútorná časṫ je hladená
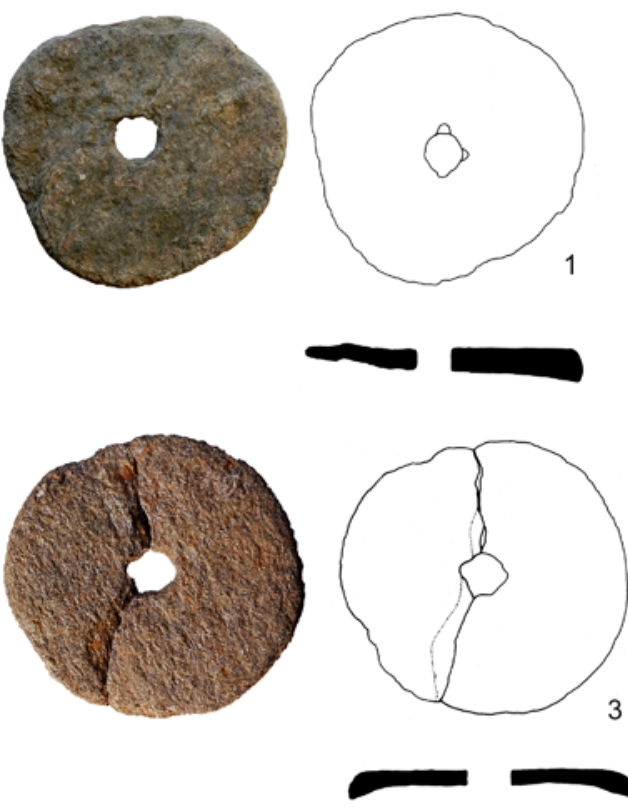
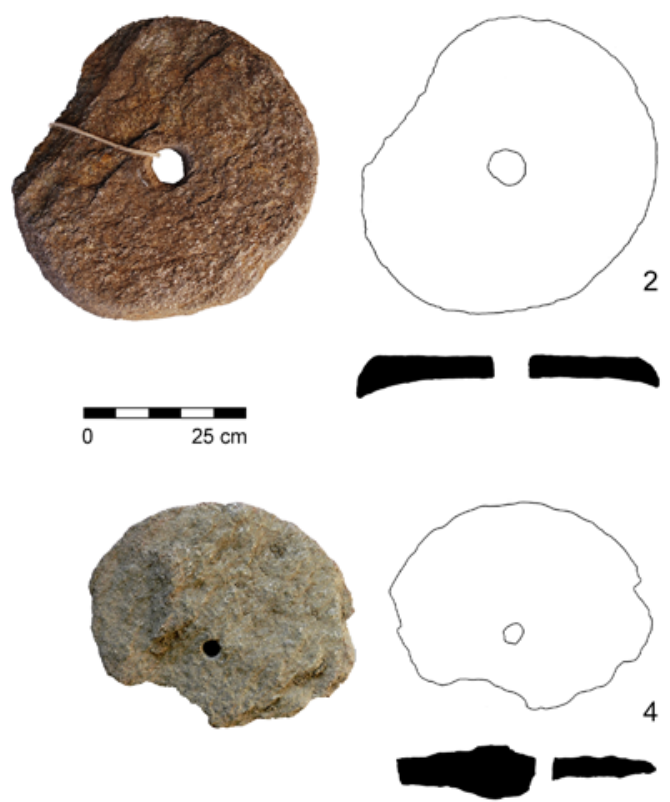

Obr. 34. Žarnovy. 1 - Objekt 86; 2 - objekt 112; 3 - objekt 114; 4 - objekt 90. Kresba J. Benech; foto J. Benech.

Fig. 34. Quernstones. 1 - Feature 86; 2 - feature 112; 3 - feature 114; 4 - feature 90. Drawing by J. Benech; photo by J. Benech. 
a na vonkajších hrubých stenách sú viditel'né typické stopy po organických prímesiach. Okraje sú nízke a zaoblené, výška, hrúbka okrajov, ako aj hrúbka dna sú nepravidelné. Dno má tendenciu zväčšovat svoju hrúbku smerom do stredu.

Okrem pestovania plodín na sídlisku prosperoval aj chov domácich zvierat (tab. 18). Ten priamo dokladá rozbor osteologického materiálu, ktorý vypracovala G. Dreslerová (2020, 43-52). Percentuálny pohl'ad zastúpenia jednotlivých druhov bol v analýze skreslený dobre zachovanými kompletnými kostrami dvoch psov, koňa a prasataa. Avšak značný počet pozostatkov prasata je možné sledovat’ aj mimo dochovaného skeletu. Objavuje sa tiež hovädzí dobytok, z ktorého získavali osadníci asi najviac mäsa. Nechýbajú ani pozostatky kozy/ovce a husi. Tento stav je pre sídliská typický a bol zachytený napr. aj v Brne-Starom Lískovci (Čižmářová 1996, 278). Kosti jeleňa, divej svine, srnca a nedomestikovaného tura dokladajú loveckú činnost' (Dreslerová 2020, 44, tab. 1). Tá však bola podl’a malého množstva týchto pozostatkov len okrajovým spôsobom obživy. Vysoká kumulácia kostí v zásobnici obj. 112 je snád’ dokladom jej používania ako odpadovej jamy.

Činnosti na sídlisku sa neobmedzovali iba na pol'nohospodárstvo. Medzi činnosti doložené malým počtom drobných nálezov patrí textilná výroba, spracovanie kostí a kože, kováčstvo aj výroba keramiky. Podomácky charakter keramickej produkcie jasne dokladá spôsob jej výroby a s ním spojený hrubý zle vypálený materiál. To isté platí pre viditel’ne konzervatívny prístup $\mathrm{k}$ výzdobe. Lepšie robená keramika $\mathrm{z}$ jemného materiálu sa na sídlisku vyskytuje minimálne a môže íst̉ o import z ned’alekého hradiska Staré Zámky u Líšně.

Textilnú výrobu, resp. podomácke tkanie priadze dokladajú štyri nezdobené prasleny z obj. 4, 62, 91 a 130 (obr. 35, tab. 19). Na opis praslenov boli použité vybrané kvality z databázy, ktorá vychádza z deskriptívneho systému (Marek, Kostelníková 1998,

\begin{tabular}{|c|c|c|}
\hline \multicolumn{3}{|c|}{ Doba hradištní } \\
\hline Druh & Počet & Hmotnost v gramech \\
\hline Bos primigenius f. taurus & 60 & 3899 \\
\hline Ovis ammonf. aries & 2 & 12 \\
\hline Ovis-Capra & 21 & 178 \\
\hline Sus scrofaf. domestica & 133 & 1193 \\
\hline Equus caballus & 178 & 12680 \\
\hline Canis lupusf. familiaris & 172 & 1315 \\
\hline Gallus gallusf. domestica & 9 & 13 \\
\hline Domácí & 575 & 19290 \\
\hline Bos primigenius & 1 & 18 \\
\hline Cervus elaphus & 10 & 52 \\
\hline Capreolus capreolus & 1 & 7 \\
\hline Sus scrofa & 1 & 39 \\
\hline Mollusca & 51 & 62 \\
\hline Volně žijící & 64 & 178 \\
\hline Canis lupus/f.familiaris & 137 & 334 \\
\hline Microtus sp. & 1 & 1 \\
\hline Domácí/volněžijící & 138 & 335 \\
\hline Homo sapiens sapiens & 12 & 49 \\
\hline Homo sapiens sapiens & 12 & 49 \\
\hline Určeno & 789 & 19852 \\
\hline MV-SV & 1 & 2 \\
\hline SV & 151 & 301 \\
\hline VV & 61 & 855 \\
\hline Neurčeno & 213 & 1158 \\
\hline Celkem & 1002 & 21010 \\
\hline
\end{tabular}

Tab. 18. Zastúpenie druhov zvierat na sídlisku (Dreslerová 2020, 44, tab. 1). Tab. 18. Representation of animal species at the settlement (according to Dreslerová 2020, 44, Tab. 1).

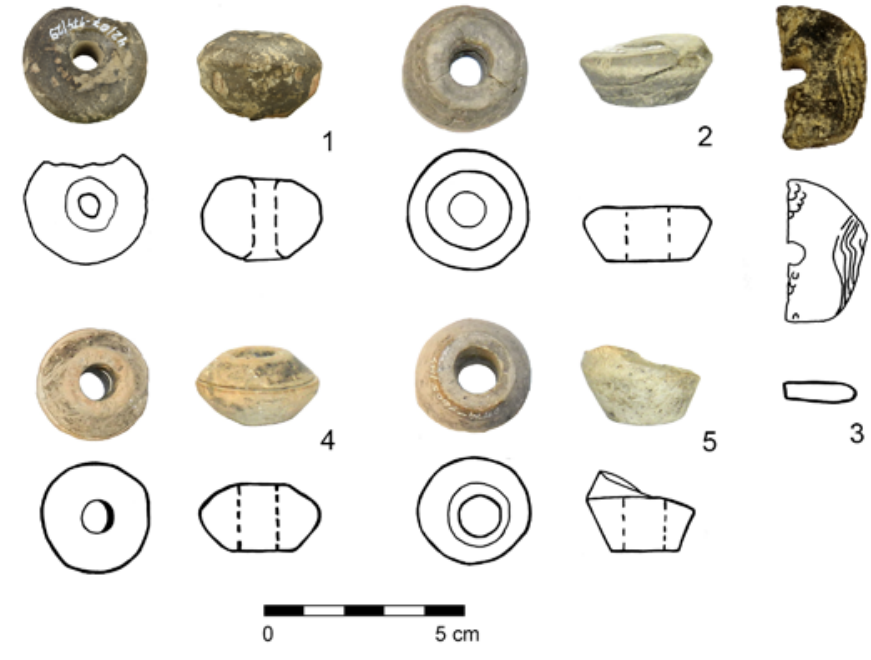

Obr. 35. Prasleny. 1 - Objekt 130. Kresba J. Benech. 2 - objekt 91; 3 - objekt 14; 4 - objekt 4; 5 - objekt 62. Kresba podl'a Geisler 1992, obr. 67, 74, 98, 118; foto J. Benech.

Fig. 35. Spindle whorls. 1 - Feature 130. Drawing by J. Benech. 2 - feature 91; 3 - feature 14; 4 - feature 4; 5 - feature 62. Drawing after Geisler 1992, Fig. 67, 74, 98, 118; photo by J. Benech.

\begin{tabular}{rlll} 
Č. obj. & Stav dochovania & Tvar & Materiál \\
\hline 130 & L'ahko poškodený & C sudovitý & Keramika \\
\hline 62 & L'ahko poškodený & B bikónický & Ílovitý prachovec \\
\hline 4 & Pozdížne rozlomený & B bikónický & Ílovitý prachovec \\
\hline 91 & Pozdížne rozlomený & B bikónický & Prachovcová bridlica \\
\hline
\end{tabular}

Tab. 19. Analýza praslenov.

Tab. 19. Analyses of spindle whorls.

172-179), upravenej H. Březinovou a R. Přichystalovou a použitej na analýzu praslenov z Břeclavi-Pohanska. Sledujeme objekt, kde sa nález nachádzal, stav zachovania kusu, tvar, výzdobu, jej umiestnenie (Březinová, Přichystalová 2014, 177-180) a materiál. Dva prasleny boli vyrobené z ružovkastého (obj. 4) a žlto-šedého (obj. 62) ílovitého prachovca (obr. 35: 4, 5), pričom kus z obj. 62 obsahoval výraznú prímes jemného muskovitu. Prasleny z ílovitého prachovca sa vo vel'kom nachádzali tiež na lokalitách Mikulčice a Břeclav-Pohansko (Přichystal 2009, 245). Praslen z obj. 91 (obr. 35: 2) bol z prachovcovej bridlice s prímesou muskovitu. Táto hornina je tiež hojne zastúpená na spomínaných lokalitách. Kus z obj. 130 (obr. 35: 1) bol z keramiky. Ílovitý prachovec aj prachovcová bridlica podl'a všetkého pochádzajú z flyšového pásma západných Karpát (Přichystal 2009, 246-247). Muskovit je taktiež miestnou surovinou pochádzajúcou z južnej Moravy. Je zaujímavé, že všetky štyri prasleny majú nepatrné stopy čierneho náteru, ktorý je viditel'ný pod mikroskopom.

V obj. 14 sa našiel pravdepodobne tiež praslen (obr. 35: 3). Bol zlomený na polovicu v osi otvoru a má diskovitý tvar. Vybrúsený bol z kusa keramiky. Stopy po hustej nízkej vlnovke a hrebeňových vpichoch sú viditel'né vel'mi dobre. Priemer praslenu je asi $4 \mathrm{~cm}$ a hrúbka približne $7 \mathrm{~mm}$.

Spracovanie kože indikuje sedem kusov zahrotených predmetov, tzv. preplietačiek vyrobených z dlhých kostí. Dve boli nájdené v obj. 130, dve v obj. 128, dve v obj. 109 a jedna v obj. 129. Jedna bola vyrobená z tibie psa (obr. 36: 5), zvyšných šeste z tibie ovce/kozy (obr. 36: 1-4, 6-7). Kostené preplietačky určila 

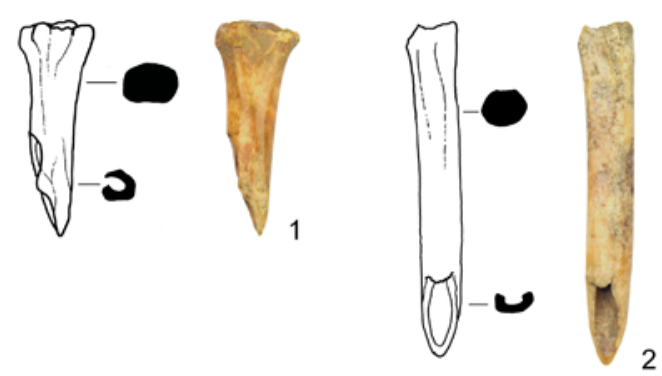
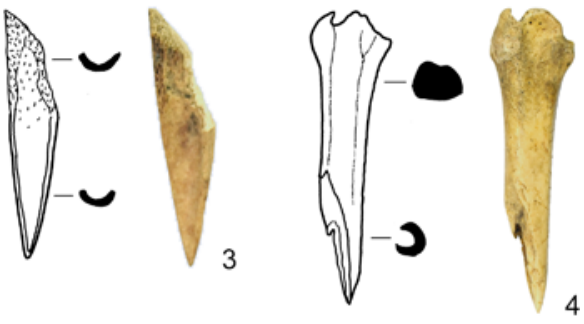
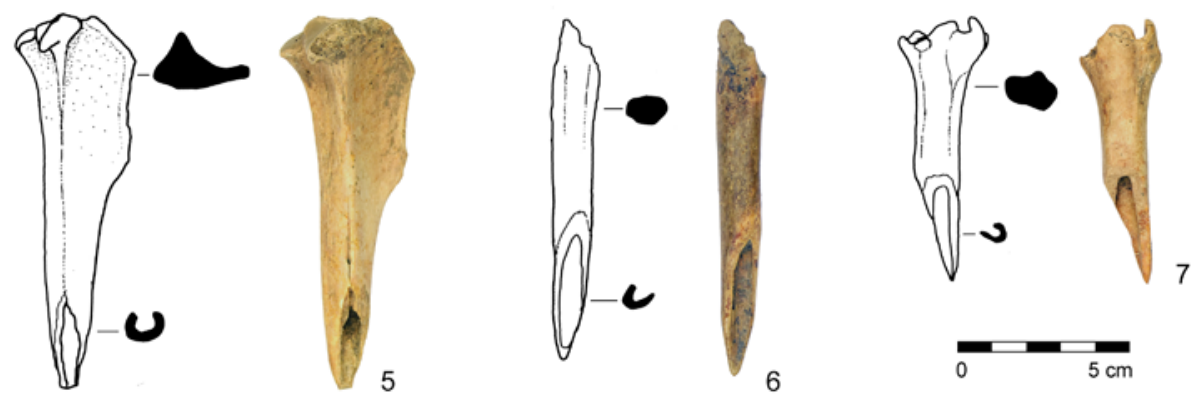

Obr. 36. Hrotité nástroje (šidlá, preplietačky). 1, 2 - objekt 128;

3 - objekt 129; 4, 5 - objekt 109;

6,7 - objekt 130. Kresba J. Benech; foto J. Benech.

Fig. 36. Pointed tools (bone aw/s) 1, 2 - Feature 128; 3 - feature 129; 4, 5 - feature 109; 6, 7 - feature 130. Drawing by J. Benech; photo by 5
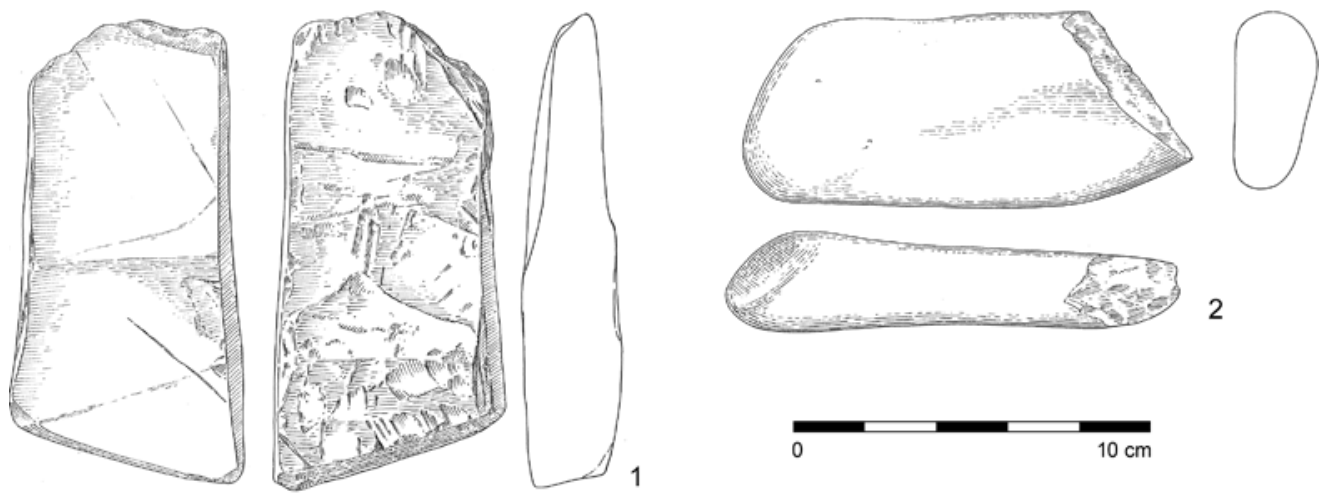

2
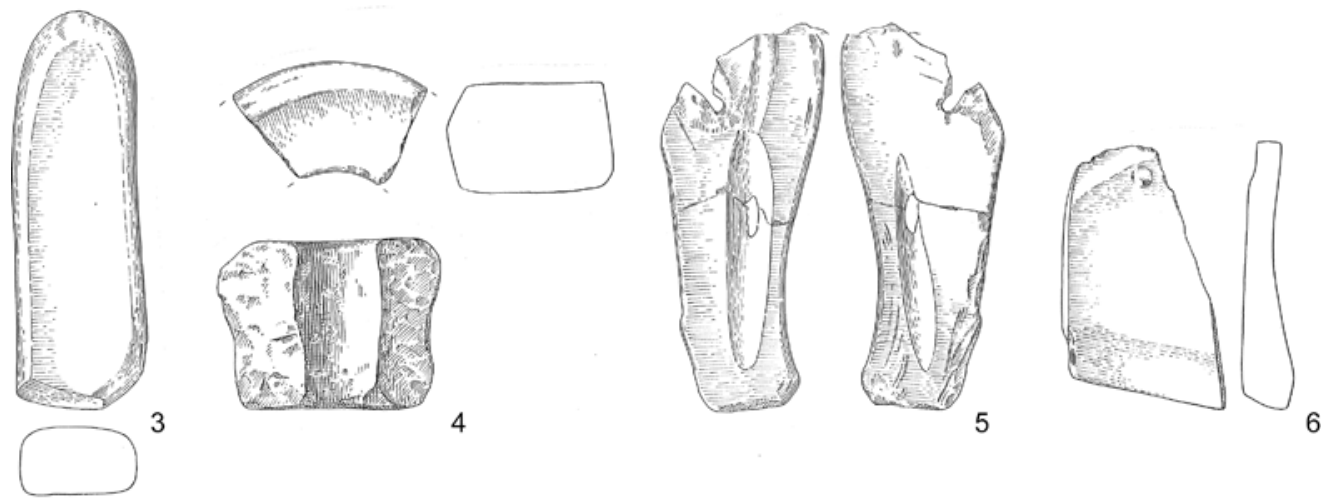

Obr. 37. Brúsiky. 1, 6 - objekt 21 2 - objekt 5; 3, 4 - objekt 106; 5 - objekt 79. Podl'a Geisler 1992 obr. 133, 134.

Fig. 37. Wet stones. 1, 6 - Feature 21; 2 - feature 5; 3, 4 - feature 106; 5 - feature 79. After Geisler 1992, Fig. 133, 134.

\begin{tabular}{rllrrl}
\hline Č. obj. & Typ & Brúsne plochy & Dížka & Šírka & Poznámka \\
\hline 5 & I & 1 & $13 \mathrm{~cm}$ & $6 \mathrm{~cm}$ & Brúsik s vodou vyhladeného kameňa \\
\hline 21 & II & 4 & $8 \mathrm{~cm}$ & $4,5 \mathrm{~cm}$ & Brúsik má na konci dierku \\
\hline 79 & II & 3 & $11 \mathrm{~cm}$ & $4,5 \mathrm{~cm}$ & Brúsik je plochý, ale má asymetrický tvar a dieru v tele \\
\hline 106 & II & 2 & $13,5 \mathrm{~cm}$ & $6 \mathrm{~cm}$ & \\
\cline { 2 - 6 } & I & 1 & $11,5 \mathrm{~cm}$ & $3,5 \mathrm{~cm}$ & Brúsik s vodou vyhladeného kameňa \\
\cline { 2 - 6 } & IV & 1 & - & - & Vnútorný priemer 4 cm a vonkajší $10 \mathrm{~cm}$ \\
\hline
\end{tabular}

Tab. 20. Analýza brúsikov.

Tab. 20. Analyses of wet stones. 
G. Dreslerová v nepublikovanom posudku. Majú pozdížne štepy a hladené hrany, na konci na oboch stranách zrezané do tvaru plochého hrotu (Bartošková 2003, 230-233). Tieto nástroje slúžili na prerážanie otvorov najčastejšie do kože, ale taktiež na zošívanie textilu. $\mathrm{V}$ minulosti používané delenie podobných kostených hrotov na preplietačky, šidlá a šidlá-preplietačky je v rámci zhotovovania kruhových otvorov prekonané. S kosteným hrotom nie je možné efektívne, bez natrhnutia materiálu, urobit do kože kruhový otvor. Ovel’a jednoduchšie sa v tomto prípade pracuje so železným hrotom, preto by sme mohli hovorit o šidlách. Rovnako otvory vo väčšine dochovaných kožiach majú podobu rovnej trhliny (Procházka 2017, 254). Taktiež ani zahraničná literatúra toto delenie nepoužíva.

Polotovar kosteného hrotu z chaty, obj. 19, dokladá spracovanie kostí. Distálny koniec nástroja je zahrotený (obr. 32: 1). Na nehladenom náleze sú viditel'né stopy po opracovaní nožom. Koniec hrotu nenesie stopy používania, ide teda pravdepodobne o polotovar či nepodarený kus. Výsledný nástroj mal slúžit asi na perforovanie materiálu. Malý počet nálezov a ich neorganizované roztrúsenie po sídlisku neumožňuje nič, len konštatovanie, že na lokalite nebola prítomná žiadna intenzívnejšia špecializovaná výroba a všetky tieto procesy prebiehali na podomáckej báze pre potreby danej komunity alebo rodiny. Spol’ahlivo identifikovat výrobný areál či aspoň dielňu sa nepodarilo.

To isté platí pre kováčstvo. To je doložené dvoma kusmi kováčskej trosky a brúsnymi kameňmi z obj. 5, 21, 79 a obj. 106 (obr. 37), ktoré sú však len nepriamym dokladom. Zatial' čo sa v obj. 5, 21, 79, 106, 130 nachádzali dobre zachované kusy viac menej vcelku (tab. 20), v obj. 37, 90 a 106 boli nájdené zlomky. Kus z obj. 130 je stratený. V obj. 106 bol zároveň uložený aj kus malého rotačného brúsiku (obr. 37: 4). Zlomky brúsikov neboli klasifikované. Dohromady bolo nájdených osem kusov, ktoré sú klasifikované podl’a systému B. Dostála (Dostál 1975, 216-219).
Ten rozlíšil štyri kategórie, a to I. amorfné brúsiky - neopracované do pravidelných tvarov, II. doštičkovité brúsiky - ploché v tvare obdížnika či lichobežníka, III. hranolovité a ihlanovité brúsiky - s konkávne vybrúsenými plochami a IV. rotačný brúsik. Vel'mi netypický kus pochádza z obj. 79 (obr. 37: 5). V strede plochého tela má vybrúsenú dierku. Tá bola viditel’ne vytvorené používaním. Slúžila na brúsenie kostených hrotov, ktoré boli otierané o jej steny v zvislej polohe. Mohla však slúžit aj ako závesný otvor. Na lokalite sa vyskytovalo aj pár neidentifikovatel'ných kusov železa a železných predmetov, a to z obj. 25 (asi recentný kus), 65, 90 (asi recentný kus), 130, 128 a 113. Nie sú však príliš výpovedné, nakol'ko sú mnohé z nich bez pochýb zo súčasnosti.

Zaujímavou činnostou, ktorá bola na lokalite objavená je hutníctvo železa. Troska sa nachádzala v obj. 58, 113, 579 a 543 pričom v prípade obj. 58, 543 a 579 to bol jeden malý kus a v obj. 113 išlo o devät kusov. V prípade obj. 543 a 579 je to pravdepodobne intrúzia, ked’že objekty sú z doby bronzovej. Troska je dokladom výroby či spracovania železa, aj ked' v tomto prípade skôr menších rozmerov. Nakol'ko sídlisko nebolo odkryté celé, je tu možnost', že bol odkrytý len okraj väčšieho výrobného areálu. Ako už bolo spomínané, sídlisko sa nachádzalo ned’aleko Moravského krasu, oblasti s bohatými ložiskami železnej rudy. Trosku analyzoval a spracoval M. Kmošek, ktorý je autorom aj nasledujúcich grafov a tabuliek (graf 10, tab. 21). Tabul'ka obsahuje iba prvky, ktoré boli v materiáli zastúpené v hodnote nad 0,03\%. Zloženie trosky bolo analyzované nedeštruktívne pomocou metódy röntgenovej fluorescencie (XRF) mobilným prístrojom Delta Professional, za použitia módu Geochem. Analýza trvala 120 sekúnd. Každý kus trosky bol analyzovaný na jednom až troch miestach podl’a jeho vizuálnej homogenity, a to na lomových plochách aj na pôvodnom povrchu. Z výsledkov meraní rôzných častí trosiek je očividná vysoká heterogenita ich materiálu, pričom najväčšiu výpovednú hodnotu majú z uvedených výsledkov výsledky z lomových

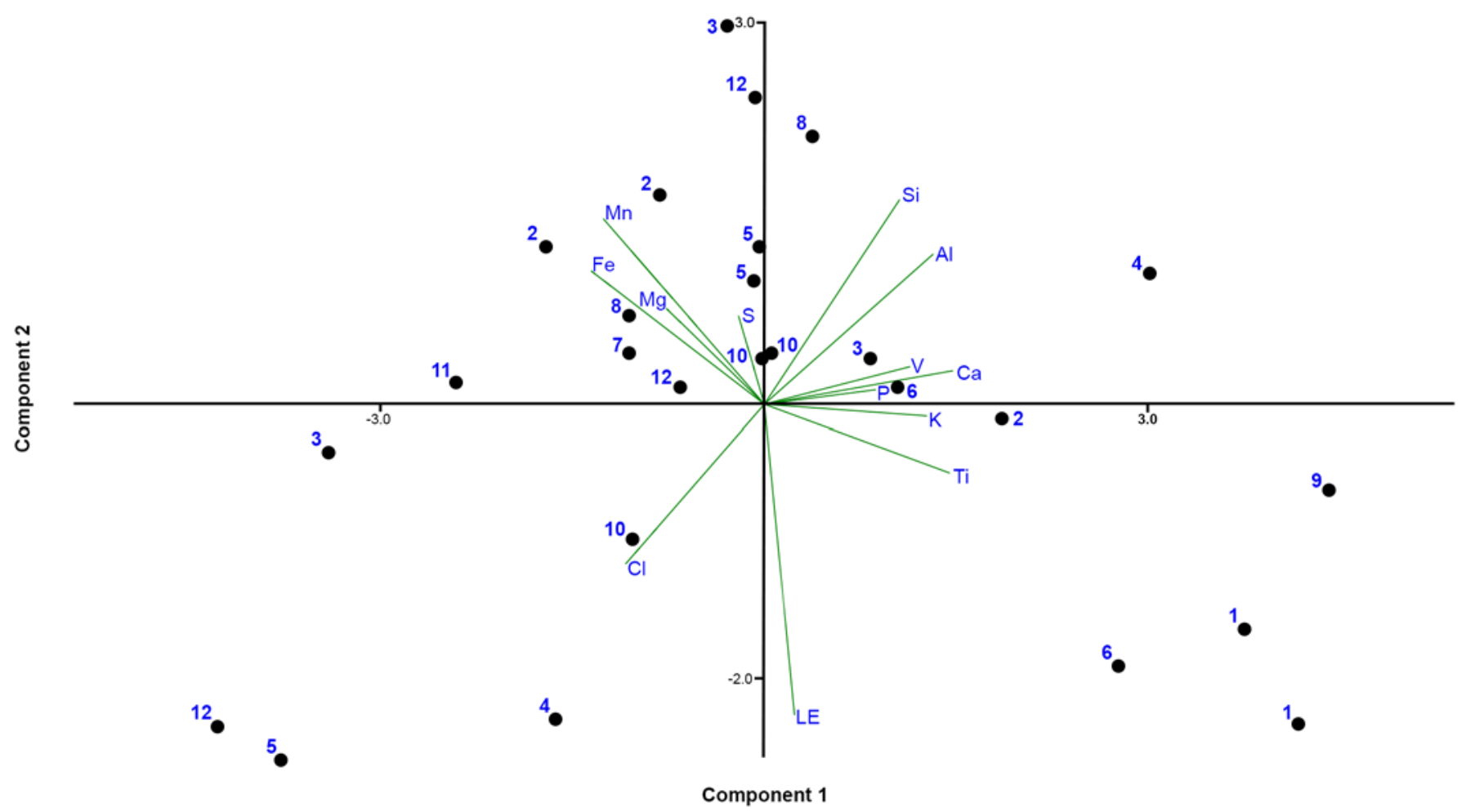

Graf 10. Analýza hlavných komponentov trosky. Autor M. Kmošek.

Graph 10. Analyses of main components in slag. Author M. Kmošek. 


\begin{tabular}{|c|c|c|c|c|c|c|c|c|}
\hline Č. trosky & Č. obj. & Inv. č. & Farba & Umiestnenie analýzy & LE & $\mathrm{Fe}$ & Si & Al \\
\hline 1 & 543 & $42 / 07-144 / 106$ & béžová & spodná strana & 56,08 & 3,71 & 24,17 & 6,70 \\
\hline 1 & 543 & $42 / 07-144 / 106$ & béžová & vrchná strana & 53,25 & 3,60 & 25,88 & 6,39 \\
\hline 2 & 579 & $42 / 07-180 / 158$ & tuhovošedá & bočnýlom & 22,69 & 41,58 & 18,46 & 4,72 \\
\hline 2 & 579 & $42 / 07-180 / 158$ & tuhovošedá & spodný lom & 25,75 & 40,16 & 20,88 & 4,60 \\
\hline 2 & 579 & $42 / 07-180 / 158$ & šedo biela & vrchný povrch & 35,59 & 28,21 & 16,81 & 5,07 \\
\hline 3 & 58 & $\mathrm{~K} 16 ; 0,58$ & čierna & vrchný povrch & 40,00 & 34,33 & 10,98 & 3,77 \\
\hline 3 & 58 & $\mathrm{~K} 16 ; 0,58$ & zelenobiela & spodný povrch & 36,83 & 22,76 & 24,62 & 5,13 \\
\hline 3 & 58 & $\mathrm{~K} 16 ; 0,58$ & zelenošedá & bočný lom & 21,02 & 32,56 & 29,24 & 6,51 \\
\hline 4 & 113 & troska $1 ; 42 / 07-183 / 45$ & šedá & bok & 26,59 & 34,25 & 16,58 & 5,64 \\
\hline 4 & 113 & troska $1 ; 42 / 07-183 / 45$ & tmavohnedá & uprostred & 45,73 & 40,90 & 5,37 & 2,18 \\
\hline 5 & 113 & troska $2 ; 42 / 07-183 / 45$ & šedobiela & spodný povrch & 27,78 & 31,97 & 25,00 & 4,98 \\
\hline 5 & 113 & troska $2 ; 42 / 07-183 / 45$ & čierna & vrchný povrch & 30,01 & 31,66 & 23,78 & 5,17 \\
\hline 5 & 113 & troska $2 ; 42 / 07-183 / 45$ & krémověšedá & bočný lom & 49,85 & 34,88 & 4,13 & 2,06 \\
\hline 6 & 113 & troska $3 ; 42 / 07-183 / 45$ & čierna & vrchný povrch & 34,02 & 29,72 & 20,71 & 5,32 \\
\hline 6 & 113 & troska $3 ; 42 / 07-183 / 45$ & krémovošedá & bočný lom & 46,94 & 19,81 & 16,10 & 4,14 \\
\hline 7 & 113 & troska $4 ; 42 / 07-183 / 45$ & hnedá & povrch & 33,12 & 34,70 & 19,83 & 3,89 \\
\hline 8 & 113 & troska $5 ; 42 / 07-183 / 45$ & krémovošedá & bočný lom & 21,16 & 35,23 & 26,43 & 6,70 \\
\hline 8 & 113 & troska $5 ; 42 / 07-183 / 45$ & čierna & vrchný povrch & 31,19 & 35,80 & 19,83 & 4,41 \\
\hline 9 & 113 & troska $6 ; 42 / 07-183 / 45$ & tmavošedá & povrch & 40,35 & 10,09 & 26,98 & 6,82 \\
\hline 10 & 113 & troska $7 ; 42 / 07-183 / 45$ & hnedošedá & vrchný povrch & 43,25 & 29,89 & 14,93 & 2,80 \\
\hline 10 & 113 & troska $7 ; 42 / 07-183 / 45$ & béžová & spodný povrch & 34,84 & 28,44 & 21,68 & 4,42 \\
\hline 10 & 113 & troska $7 ; 42 / 07-183 / 45$ & krémovošedá & bočný lom & 34,50 & 29,57 & 20,22 & 4,00 \\
\hline 11 & 113 & troska $8 ; 42 / 07-183 / 45$ & tuhovošedá & spodnýlom & 33,64 & 39,24 & 16,00 & 3,79 \\
\hline 12 & 113 & troska $9 ; 42 / 07-183 / 45$ & čierna & vrchný povrch & 46,15 & 36,02 & 4,84 & 2,44 \\
\hline 12 & 113 & troska $9 ; 42 / 07-183 / 45$ & béžová & spodný povrch & 19,00 & 36,53 & 26,27 & 5,30 \\
\hline 12 & 113 & troska $9 ; 42 / 07-183 / 45$ & krémovošedá & bočný lom & 33,93 & 34,47 & 20,11 & 4,23 \\
\hline
\end{tabular}

plôch trosiek. Analýza hlavných komponentov (graf 10) ukázala, že materiál má tendenciu tvorił dve skupiny, pokial’ ide o obsah železa a mangánu. Zatial' čo prvá menšia skupina v pravej časti grafu vykazovala malý obsah železa (tab. 21: trosky 1, 9), väčšia skupina na opačnej strane obsahovala výrazne väčšie množstvo tohto prvku. Aj v druhej skupine bol zaznamenaný vyšší obsah mangánu. Trosky bohaté na železo majú až na trosku č. 4 obsah mangánu viac ako $2 \%$. To je jeden $\mathrm{z}$ indikátorov hutníckej trosky (Souchopová 1986, 69-70; Bursák et al. 2018, 399-400). Predpokladám preto, že druhá skupina trosky č. 2, 3, 5, 6, 7, 8 by s istou pravdepodobnostou mohla pochádzat’ z hutníckej činnosti. Avšak aj v tejto skupine sa môžu vyskytovat’ kusy kováčskej trosky, napríklad troska č. 4 bohatá na železo, avšak s nízkym obsahom mangánu. Naopak porézne sklovité kusy č. 1 a 9 (tab. 21) by mohli byṫ pozostatkom kováčskeho procesu, ale sú príliš fragmentárne, aby to bolo možné tvrdit’ s istotou.
Ďalším dôležitým ukazovatel’om pôvodu trosky je jej morfológia. V. Souchopová uvádza, že kováčska troska má koláčový tvar, čo ju od hutníckej trosky odlišuje. Hutnícka je naopak tvarovo neurčitá a asymetrická. To je však vel'mi zjednodušené a úplne to neplatí. Rozlíšenie hutníckej a kováčskej trosky je vonkoncom problematické (Souchopová 1986, 69-70). Štyri kusy trosky, konkrétne kusy 2, 5 a 7 z obj. 113 a 3 z obj. 58 (obr. 38), nesú viditel'né tvarové znaky naznačujúce liatie trosky pri odpichu. Je vidiet’ asymetrické plátové tvary a drobné kamienky na spodnej časti. Sú to zvyšky zeminy v predpecnom priestore, po ktorom troska vytekala. Ďalej bola objavená čierna oxidová farba na hornej strane, ktorá sa tvorí pri kontakte so vzduchom. Kováčska troska môže byť výrazne pórovitá a drobné kamienky obsahuje len ojedinele. Na rozdiel od analýzy hlavných komponentov pozorovanie morfológie ovel’a istejšie naznačuje, že o hutnícku trosku v uvedených prípadoch išlo. Na lokalite však
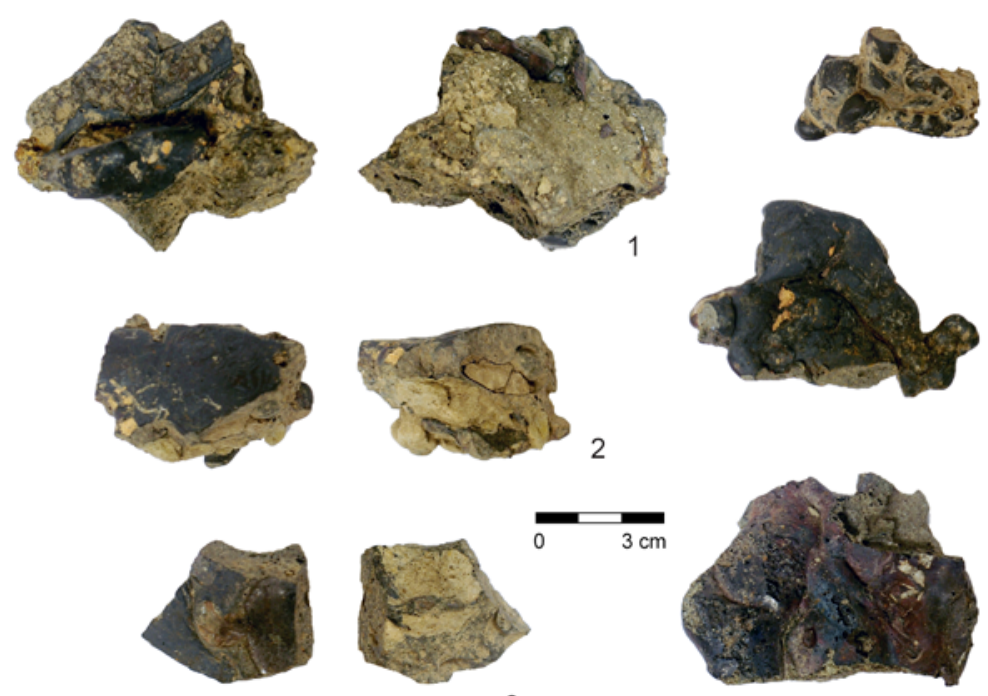

3
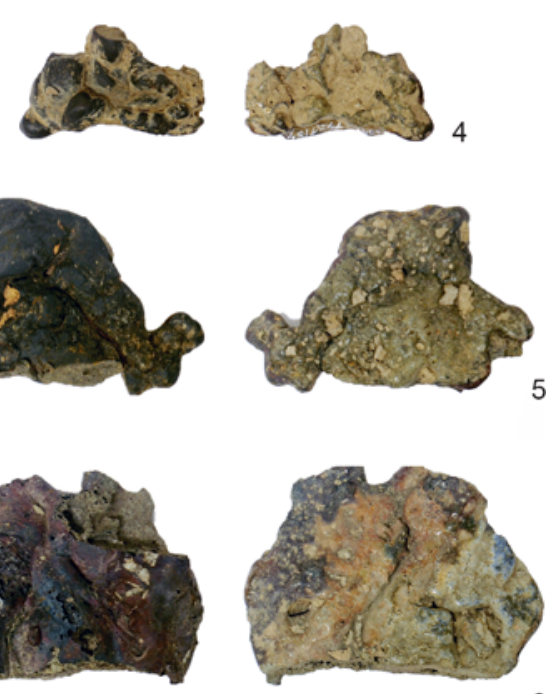

6
Obr. 38. Kusy trosky, pohled zobou stran. 1-3, 5, 6- objekt 113; 4 - objekt 58. Foto M. Kmošek.

Fig. 38. Pieces of slag, view from both sides. 1-3, 5, 6 - Feature 113; 4 - feature 58. Photo by M. Kmošek. 


\begin{tabular}{|c|c|c|c|c|c|c|c|c|}
\hline Mg & $K$ & $\mathrm{Ca}$ & Mn & $\mathbf{P}$ & s & Ti & Cl & V \\
\hline 0 & 1,99 & 5,38 & 0,08 & 0,96 & 0,02 & 0,56 & 0 & 0,04 \\
\hline 1,34 & 2,04 & 5,38 & 0,08 & 1,19 & 0,19 & 0,53 & 0 & 0,04 \\
\hline 1,94 & 0,81 & 5,42 & 2,51 & 1,53 & 0,09 & 0,15 & 0 & 0,03 \\
\hline 2,05 & 0,79 & 2,31 & 2,35 & 0,85 & 0,01 & 0,14 & 0 & 0,02 \\
\hline 1,60 & 2,46 & 7,32 & 1,21 & 1,27 & 0,03 & 0,26 & 0 & 0,06 \\
\hline 2,54 & 0,66 & 2,14 & 2,59 & 0,34 & 0,58 & 0,10 & 1,89 & 0,02 \\
\hline 1,45 & 1,41 & 5,10 & 1,71 & 0,41 & 0,19 & 0,24 & 0 & 0,04 \\
\hline 1,81 & 1,46 & 3,21 & 2,47 & 0,83 & 0,61 & 0,17 & 0 & 0,03 \\
\hline 1,71 & 3,38 & 5,88 & 1,08 & 4,28 & 0,14 & 0,25 & 0 & 0,11 \\
\hline 0 & 0,62 & 2,72 & 0,53 & 1,24 & 0,08 & 0,07 & 0,43 & 0,04 \\
\hline 1,29 & 1,29 & 4,02 & 2,49 & 0,80 & 0,05 & 0,21 & 0 & 0,04 \\
\hline 0,92 & 1,38 & 3,54 & 2,55 & 0,60 & 0,05 & 0,21 & 0 & 0,04 \\
\hline 2,02 & 0,53 & 1,81 & 2,15 & 0,25 & 0,03 & 0,10 & 2,09 & 0,02 \\
\hline 0 & 1,61 & 5,24 & 1,92 & 0,64 & 0,03 & 0,23 & 0 & 0,05 \\
\hline 0 & 2,14 & 5,56 & 0,04 & 4,00 & 0,11 & 0,30 & 0 & 0,05 \\
\hline 1,15 & 1,12 & 2,94 & 2,31 & 0,63 & 0,06 & 0,13 & 0 & 0,04 \\
\hline 1,50 & 1,54 & 3,77 & 2,31 & 0,96 & 0,04 & 0,22 & 0 & 0,04 \\
\hline 1,17 & 1,09 & 2,99 & 2,38 & 0,74 & 0,13 & 0,16 & 0 & 0,03 \\
\hline 1,09 & 7,11 & 5,65 & 0,09 & 1,44 & 0 & 0,26 & 0 & 0,05 \\
\hline 0 & 1,50 & 3,33 & 2,46 & 0,95 & 0,06 & 0,11 & 0 & 0,03 \\
\hline 1,06 & 1,36 & 4,37 & 2,29 & 1,15 & 0,11 & 0,18 & 0 & 0,04 \\
\hline 1,08 & 1,15 & 4,67 & 2,41 & 2,01 & 0,10 & 0,17 & 0 & 0,04 \\
\hline 1,86 & 0,65 & 1,79 & 2,23 & 0,58 & 0,02 & 0,11 & 0 & 0,01 \\
\hline 2,73 & 0,54 & 1,48 & 2,23 & 0,55 & 0 & 0,07 & 2,83 & 0,02 \\
\hline 2,07 & 1,14 & 4,64 & 2,45 & 2,22 & 0,13 & 0,15 & 0 & 0,04 \\
\hline 0 & 1,18 & 2,70 & 2,28 & 0,81 & 0,06 & 0,14 & 0 & 0,04 \\
\hline
\end{tabular}

Tab. 21. Tabul'ka percentuálneho zastúpenia prvkov v troske. Autor M. Kmošek.

Tab. 21. Table of percentage representation of components in slag. Author M. Kmošek.

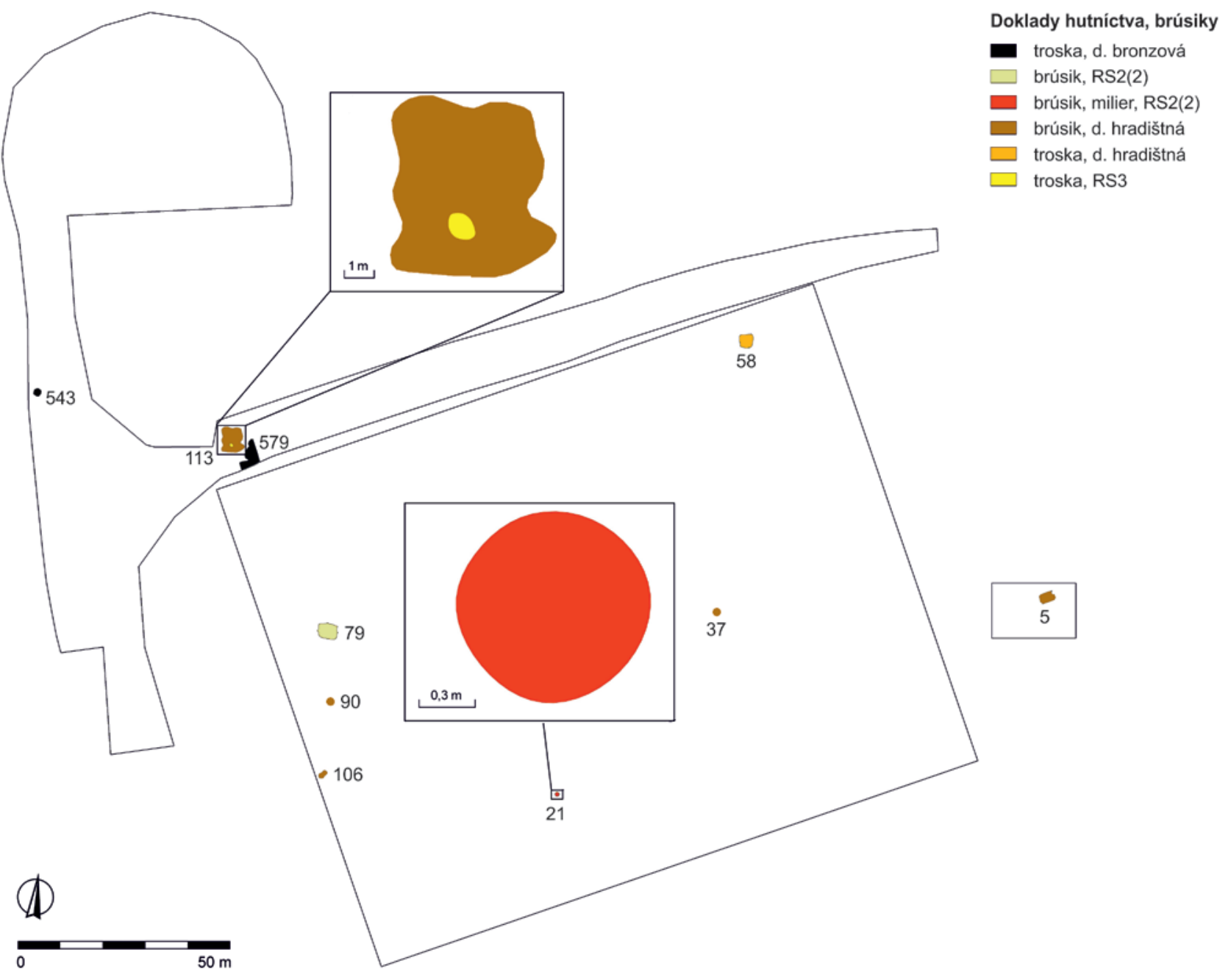

Obr. 39. Doklady hutníctva, brúsiky - priestorové zobrazenie. Autor J. Benech. Fig. 39. Evidence of metallurgy, wet stones - spatial mapping. Author J. Benech. 
nebola odokrytá ani jedna hutnícka pec, tak ako to bolo napr. na sídlisku Kuřimi, kde bola hutnícka výroba spol’ahlivo doložená. Tamojšie pece patria asi do stredohradištného obdobia, aj ked' ich datovanie nie je isté vzhl'adom $\mathrm{k}$ absencii nálezov, ktoré by s nimi bezprostredne súviseli (Procházka 1992, 325). Dôležitým dokladom tejto činnosti môže byt’ aj milier (obj. 21) na výrobu dreveného uhlia s priemerom $110 \mathrm{~cm}$. Je to $1,9 \mathrm{~m}$ hlboká jama s plochým dnom a priemerom $120 \mathrm{~cm}$ (obr. 7: obj. 21). Je situovaná v dostatočnej vzdialenosti od obytných budov (obr. 39). Nachádzala sa v nej výrazná, asi 10 cm hrubá vrstva podrvených dubových uhlíkov približne $30 \mathrm{~cm}$ nad dnom. Dub sa na výrobu dreveného uhlia používal tiež, aj ked' napríklad na lokalitách Olomučany alebo Habrůvka prevažuje buk. To však môže byt spôsobené jeho prevažujúcim výskytom v okolí spomínaných lokalít (Opravil 1986, 89-93). Takýto spôsob výroby uhlia má analógie v praveku a dokonca historické doloženie v mladších dobách (Kmošek 2011, 11-14, 42-44, obr. 14-24). Na základe toho, že sa podarilo tento objekt vd'aka keramike presnejšie datovat do fázy RS2(2) je možné tvrdit', že hutnícka výroba prebiehala na sídlisku už v 8. storočí. Aj napriek tomu, že uhlie mohlo mat aj iné využitie je pravdepodobnejšie, že sa vyrábalo práve pre hutnícku produkciu. Zostáva otázkou, či obyvatelia sídliska spracovávali rudu z ned’alekého Moravského krasu, kde bola tazžba doložená tiež už v 8. storočí, alebo spracovávali rudu z miestnych miniatúrnych ložísk (Souchopová 1995, 13-14, 35-36, 46-47). V každom prípade sa na základe nálezov nedá tvrdit, že by šlo o produkciu väčších rozmerov.
V rámci dokladov remeselnej výroby bolo zo sídliska získaných len vel’mi málo informácii. Je to spôsobené nízkym počtom samotných nálezov dokladajúcich daný typ výroby a rovnako ich roztrúsením (obr. 39, 40). Jediným dokladom kováčstva boli snád' tri kusy trosky, ktoré sa nachádzali v dvoch objektoch. Č́́slo 1 ako intrúzia v obj. 543 z doby bronzovej a č. 4 a 9 z obj. 113. Zvyšok vyznačených objektov obsahoval len brúsne kamene rôznych tvarov, čo je však len nepriamy doklad. To isté sa týka hutníctva. Milier a objekty s obsahom hutníckej trosky sa nachádzali prakticky na opačných stranách odkrytej plochy. $\mathrm{Na}$ základe vel'kej koncentrácie tejto trosky v obj. 113, teda v zásobnici v podlahe chaty v severnej časti sídliska, je možné konštatovat', že výroba sa uskutočnila v jej blízkosti. Doklady hutníckych pecí sa v okolí objektu ani na celej ploche nepodarilo nájste.

Taktiež podoba keramiky, jej hrubý materiál, pomalé obtáčanie a zväčša vel'mi nekvalitný výpal vylučujú špecializovanú produkciu. Doklady textilnej výroby či spracovania kože a kostí sú len minimálne a v prípade kože otázne. Nájdené preplietačky sa na prácu s kožou mohli aj nemuseli používat, naopak, ich využitie pri práci s textilom nepriamo dokladajú prasleny. Výroba na sídlisku mala podl’a všetkého charakter podomáckej výroby pre vlastnú spotrebu, tak ako ju definoval D. P. S. Peacock $(1982,8)$ pri skúmaní výroby rímskej keramiky. Výroba keramiky, textilu, kože či jednoduchých kostených hrotov uspokojovala základné potreby domácnosti, kde bola vyrábaná. Predstavovala druhoradú sporadickú činnosť vykonávanú len v prípade potreby. Predpokladat môžeme výmenu produktov maximálne

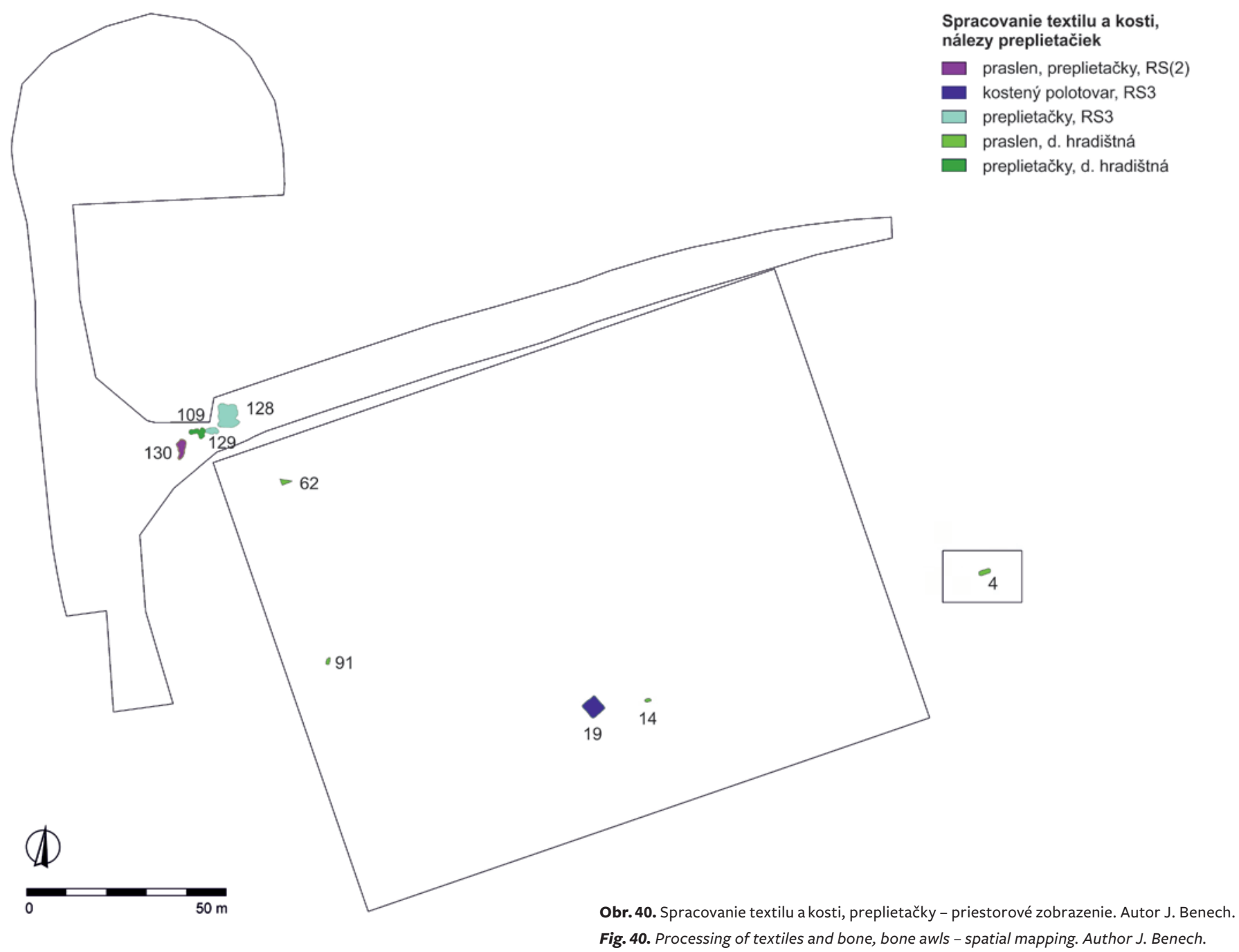


medzi domácnostami na danom sídlisku. V prípade kováčskej produkcie, ak na sídlisku naozaj nejaká bola, možno uvažovat aj o tzv. špecializovanej podomáckej výrobe (Peacock 1982, 17-24). Primárnym dôvodom je skutočnost', že táto výroba je náročnejšia v nárokoch na zručnost výrobcu, ale aj na pracovné nástroje. Taktiež nie je isté, že malé sídlisko spotrebovalo tol'ko kováčskych produktov, aby ich muselo vyrábat niekol'ko výrobcov. Je pravdepodobnejšie, že železné výrobky a ich servis zabezpečoval jeden alebo dvaja kováči, ktorých práca bola sporadická a výlučne pre uspokojenie potrieb členov komunity. Sporadická výroba uspokojujúca potreby malej komunity ale neumožnila hlbšiu špecializáciu. Nakol'ko aj samotná kováčska výroba na sídlisku nie je úplne istá, je táto úvaha iba hypotetická. Otázny je charakter hutníckej produkcie. Na jednej strane nebol objavený ani jeden výrobný objekt, resp. hutnícka pec, na strane druhej je nepravdepodobné, že by hutnícka výroba vo vidieckej osade uspokojovala potreby len miestnej komunity, aby jej produkty neuspokojovali trh aspoň v okolitom regióne. Nemožno povedat', či sa tam daná činnost̉ konala celoročne alebo len sezónne, teda či boli miestni výrobcovia špecializovaní na hutnícku výrobu a iným výrobným činnostiam sa nevenovali. Hutnícka produkcia, tak ako kováčska, je zároveň náročnejšia na technológiu, zručnosti a výrobné prostriedky. S nedostatočnými dátami, ktoré máme, možno len konštatovat', že hutnícka produkcia mohla niesť charakter tzv. výroby v individualizovaných dielňach, teda že niesla určitý nutný stupeň špecializácie a bola určená aj pre vonkajší trh (Peacock 1982, 25-43).

Roztrúsené sú aj doklady ostatných výrobných činností (obr. 40). Pozoruhodná je zvlášt koncentrácia spracovania tzv. preplietačiek a praslenov v chate 128 na severe plochy a jej blízkom okolí. Je otázne, či túto chatu možno interpretovat ako nejakú „dielňu“. Po prvé, samotných nálezov je príliš málo, aby bolo možné o niečom takom uvažovat a po druhé, prítomnost̉ dvoch zásobníc (objektov na skladovanie potravín) v podlahe remeselnej dielne je nanajvýš nelogická. Rovnako nie je známa presná poloha nálezov v objektoch, kvôli čomu ani nie je známe, či s objektom $\mathrm{v}$ dobe jeho používania súviseli. Z toho jasne vyplýva, že žiaden výrobný areál ani dielňa na sídlisku odkrytá nebola a dané nálezy dokladajú iba drobnú domácu výrobu s výnimkou hutníctva, ktoré mohlo byt’ sezónne.

Pri porovnaní funkcie so súdobými sídliskami je nutné vynechat v tomto kontexte známe sídlisko v Brne-Starom Lískovci, pretože doklady akejkol'vek výroby absolútne chýbajú a nálezový súbor okrem mazanice a zvieracích kostí pozostáva len z keramiky (Čižmářová 1996, 271-276). Naopak, vel'mi vhodným sa ukázalo sídlisko v Březne u Loun. Podoba výroby je vel'mi podobná Brnu-Medlánkam. Nachádzalo sa tu len málo nálezov dokladajúcich výrobu. Boli to žarnovy a zlomky pražníc, dokladajúce pol'nohospodársku činnost', rovnako sa tam nachádzali prasleny a malé železné nožíky. V inventári nechýbali ani kamenné brúsiky (Pleinerová 1975, 61-74). Charakter nálezov oboch sídlisk sa odlišoval iba prítomnost’ou hutníckej výroby, ktorá v Březne nebola a môže súvisiet’ s absenciou bližších väzieb na nejaké centrum. Sídlisko Mikulčice-Podbřežníky bolo z praktického hl'adiska podobné. Existovalo od včasnoslovanského po stredohradištné obdobie. Tak ako v Medlánkach, aj tu sa nachádzali prasleny, tzv. preplietačky, brúsiky, železné nože či žarnovy. Inventár obsahoval aj sekerovitú hrivnu, čo môže byt̉ následkom susedstva s centrálnou lokalitou Mikulčice (Mazuch 2008, 166-171). Sídlisko v Kuřimi, datované do stredohradištného až mladohradištného obdobia, bolo podobné vyššie uvedenými dokladmi železiarskej výroby. V nálezovom súbore nechýbajú prasleny, kostené preplietačky, hroty a drobné železné nožíky. Žarnovy na sídlisku neboli nájdené, namiesto nich sa objavila vel'mi vzácna zrnoterka (môže byt' z praveku). Troska dokladá prítomnosṫ kováčskej výroby. Zaujímavým nálezom bola bronzová ihlica ako ojedinelý doklad šperku (Procházka 1992, 319-325). Včasnostredoveké sídlisko Mutěnice-Zbrod, datované do 7.-10. storočia, malo tiež podobnú paletu nálezov. Okrem preplietačiek a hrebeňov bola nájdená aj ihla či kostená časť tzv. korčúl'. Nebol tu žiaden výrobný areál, avšak nájdených bolo pár kusov železných ozdôb, olovený krížik, bronzová pracka, ojedinelé militárium v podobe železného hrotu šípu, dve prevliečky a súčasti konského postroja (Klanica 2008, 204-224). Sídlisko v Brne-Medlánkach svojím inventárom teda nijak nevybočuje z reálií vidieckeho osídlenia, ktoré je primárne pol'nohospodársky zamerané s malou prímesou rôznej podomáckej výroby, prípadne dokladom železiarstva. Inventár je ako u väčšiny vidieckych sídlisk vel’mi chudobný na počet aj pestrosṫ.

\section{Depónie l'udských a zvieracích kostí na sídlisku}

Zaujímavým fenoménom na sídlisku bola l’udská kostra v zásobnici obj. 124. Horný okraj mal tvar nepravidelného oválu z rozmermi $240 \times 220 \mathrm{~cm}$. V híbke $60 \mathrm{~cm}$ lemoval jamu obvodový stupeň, ktorý ju výrazne zužoval. Dno malo rozmery $130 \times 100 \mathrm{~cm}$. Obilná jama bola v nálezovej správe datovaná do stredohradištného obdobia, avšak toto datovanie je vel'mi sporné. V objekte sa totiž našiel len jeden kus keramiky stredohradištného obdobia, jeden praveký črep a dva nedatované črepy (Geisler 2008a, 21, 92; 2008b, 394). L'udská kostra ležala v híbke 150-170 cm. Iba hrudník, panva a jedna horná končatina ležali $\mathrm{v}$ anatomickej polohe. Horná časť tela ležala na chrbte nachýlená na pravý bok a lopatky ležali dorzálne s humerom smerujúcim do strany. Pravá lopatka s humerom je dislokovaná. Lebka, z ktorej sa našli len zlomky, ležala nad telom v híbke $50 \mathrm{~cm}$ a oddelená dolná končatina ležala na náprotivnej strane objektu (Piačková 2018, 61-62). Telo (obr. 41) bolo podl'a všetkého pohodené. Kostra nebola v anatomickej polohe a milodary, resp. akékol'vek doklady pietneho pohrebu chýbali. Spôsob uloženia vôbec nezodpovedal v tomto období zaužívanému spôsobu ukladania, teda v natiahnutej polohe na chrbte alebo kremácie, ako to bolo v staršom období (Čechura 2010, 114-115). Takéto uloženie mohlo mat niekol'ko dôvodov. Mohlo íst’ o pohodené telo po násilnom zániku osady alebo mohlo íst o vraždu, vyvrhel'a, cudzinca, otroka, telesne poškodenú osobu

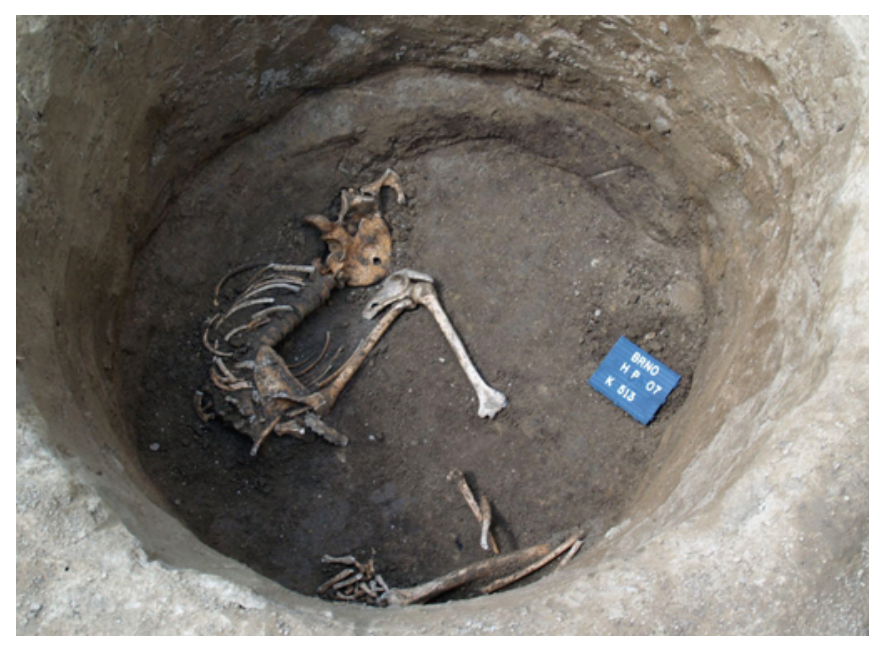

Obr. 41. Obilná jama, objekt 124 s l'udským skeletom. Podl'a Geisler 2008a, tab. 10. Fig. 41. Storage pit, feature 124 with human skeleton. After Geisler 2008a, Tab. 10. 
či rituálnu praktiku (Unger 2010, 166-167). Prvá možnost bola bez zánikového horizontu či prítomnosti akýchkol'vek militárií a iných tiel vylúčená. Rovnako už spomínané umiestnenie žarnovov indikuje skôr opustenie osady. Taktiež vražda je vzhl’adom k uloženiu v relatívnej blízkosti obytnej zóny vel'mi nepravdepodobná. Zlé zachovanie kostry nedovol'uje rozlíšit pohlavie, presnejší vek, ani prítomnoste telesného poškodenia. Príslušnost jedinca $\mathrm{k}$ vrstve otrokov je vo vidieckom prostredí zriedkavá. Rituálne konanie býva naznačené zväčša prítomnostou milodarov, kostier zvierat či kostier iných l'udí nesúcich špecifické spoločné znaky, ako napr. v prípade depónie dvoch žien a dvoch detí spolu s množstvom zvieracích kostí na lokalite Letonice (Drozdová, Šedo 2004, 223-235). Nič z toho však depónia z Medlánok neobsahovala. Dôležitou skutočnostou zostáva, že hlava jedinca sa nachádzala pol metra nad zvyškom tela. Dôležitou otázkou preto je, či bola od neho oddelená a hodená k telu nasledovne. Zlé zachovanie kostry neumožnilo rozlíšit stopy po dekapitácii, no aj napriek tomu je možná a naznačuje skôr to, že jedinec bol popravený a jeho hlava pár dní vystavená na výstrahu ostatným členom spoločenstva. Potom bola hodená do zásobnice. Tresty useknutím končatín neboli na našom území vo včasnom stredoveku ojedinelé. Podobným spôsobom bol interpretovaný aj muž pohodený v zemnici s chýbajúcou častou l'avej nohy od kolena nadol a kost̉ami pravého chodidla, z južného predhradia Břeclavi-Pohanska (Přichystalová 2010, 143-145, 148-149).

Na sídlisku boli nájdené aj depónie kompletných zvieracích kostier. Ucelené kostry sú na rozdiel od klasických fragmentárnych/odpadových nálezov roztrúsených v objektoch výsledkom zámernej l’udskej činnosti. Na sídlisku v Brne-Medlánkach boli nájdené uložené pozostatky dvoch psov a koňa. Práve tieto zvieratá patria medzi vel'mi často uložené druhy (Miklíková 2010, 148-150). Spomínané kostry dvoch psov sa nachádzali v zásobnici obj. 159. Ich prítomnosť na včasnostredovekom sídlisku nie je výnimočným javom, dokonca sa objavujú aj vo funerálnych kontextoch (Miklíková 2010, 125, 126, tab. 1, 127). Podl'a analýzy šlo o druh podobný dobermanovi a whippetovi/foxteriérovi. Jeden z nich mal na kosti stopy rezania (Dreslerová 2020, 45, obr. 3). Je možné, že stopa je po zranení z boja s nejakou osobou, možno pri obrane pána. Taktiež to môže byt doklad týrania. Ich „pietne“ uloženie môže byt znakom určitého pozitívneho vztahu s l'udským spoločenstvom. Prítomnost predstavy, že by pes pochovaný v relatívnej blízkosti osídlenia mohol byṫ „strážcom“ aj po smrti, sa nedá vylúčit. Táto predstava by naopak vylúčila spomínanú konzumáciu.

Kompletnú kostru koňa (obr. 42) približne 150 cm vysokého, zachovanú v anatomickej polohe v zásobnici obj. 157, je kvôli neprítomnosti sprievodného materiálu tažké datovat'. Poloha objektu je mierne mimo centra osady, asi 15 metrov od kumulácie hradištných objektov. Naopak, priestorovo je blízko skupinky objektov z doby bronzovej. Rámcové datovanie do doby hradištnej však bezpečne umožňuje typický hruškovitý tvar objektu. Tento tvar sa u zásobníc z mladšej doby bronzovej nevyskytuje. Poškodenie predných zubov, ktoré bolo objavené na kostre naznačuje používanie zubadla. Uloženie jeho tela mohlo mat rovnaké symbolické pozadie ako v prípade dvoch psov až na skutočnost', že kôň neplnil rolu strážcu, ani domáceho zvierata. Kôň bol podl'a všetkého jazdeckým zvieratom. Aj napriek tomu, že neboli nájdené žiadne ostrohy, využitie koňa odhalili stopy po zubadlách na jeho čel'usti. Nasvedčuje tomu zrastenie tŕňových výbežkov na chrbtici v oblasti hrudníka. To býva spôsobené skokmi, skokmi cez prekážky či pádmi pod tlakom v oblasti chrbta (Dreslerová 2020, 47, 48, obr. 11, 12). Samotná prítomnost' koňa na včasnostredovekom sídlisku však nie je ničím
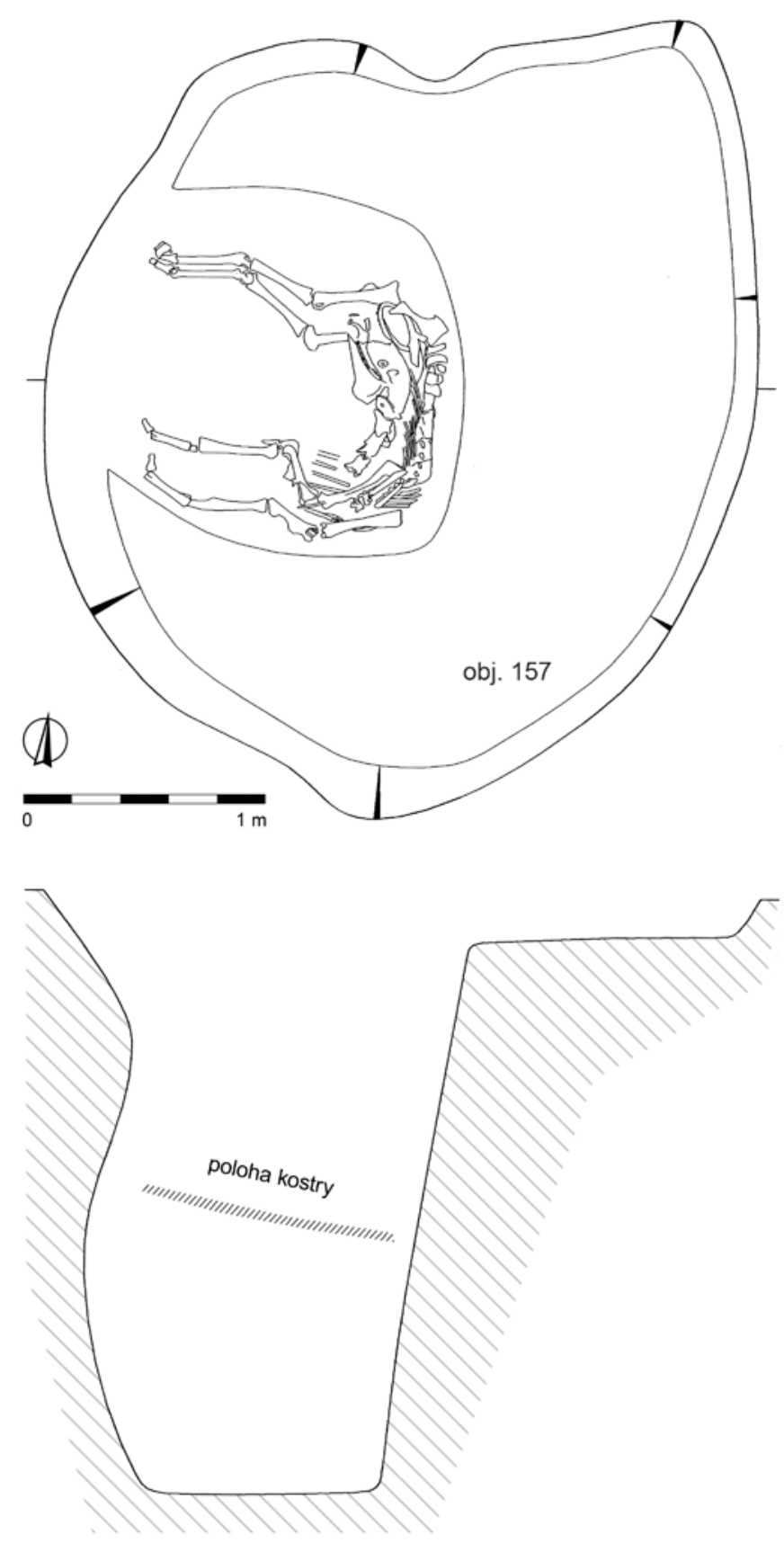

Obr. 42. Objekt 157 s kostrou koňa. Podl'a Geisler 2008a, obr. 27.

Fig. 42. Feature 157 with horse skeleton. After Geisler 2008a, Fig. 27.

výnimočným a existujú početné analógie. Až na pár výnimiek (napr. Bajč) sú však pozostatky koňa na jednotlivých sídliskách kusovo menej zastúpené (Miklíková 2010, 126, tab. 1, 142-143, 145). Je nesporné, že kôň mal v slovanskej mytológii svoje čestné miesto ako atribút niektorých vojnových a solárnych bohov, menovite Svarožič, Triglav či Svantovít (Profantová, Profant 2004, 113-115), či ako prostriedok veštenia a ekonomicko-vojenského úspechu (Dynda 2016, 63-69, 73-79). Význam a príčina jeho depónie, rovnako ako depónie dvoch psov, je ovel’a menej „symbolická“. Z. Miklíková sa domnieva, že účel podobných uložení bol hygienický, išlo o zbavenie sa uhynutých zvierat. Pre iné interpelácie ako napr. náboženské obete, niet na sídlisku potrebných dôkazov. 


\section{0. Štruktúra a priestorový vývoj sídliska}

Sídlisko v Brne-Medlánkach bolo nájdené na dvoch hlavných plochách (obr. 43). Severná bola odkrytá počas výskumu v roku 2007 a južná v roku 1984, spolu s malým obdížnikovým odkryvom smerom na východ. Lokalita nebola odkrytá celá, severnú hranu sa ale s najväčšou pravdepodobnostou zachytit’ podarilo. Slovanské osídlenie začalo na prelome 6. a 7. storočia a skončilo v závere 9. storočia alebo až v 10. storočí. Presnejšie sa podarilo datovat len 18 objektov, zvyšok bol zaradený do širšej kategórie doby hradištnej a mnoho zostalo úplne nedatovaných. To znemožňuje dostatočne objavit priestorový vývoj sídliska v čase. Ako je z mapy lokality zrejmé, v rámci severnej plochy, resp. plochy novšieho výskumu boli presnejšie datované štyri objekty. Problém plochy spočíva $v$ tom, že mnohé tamojšie objekty obsahovali vel'mi málo signifikantných kusov keramiky. Viditel'ne v nich neprevažoval nijaký konkrétny horizont. Len vel’mi málo výpovedných kusov sa v objektoch nachádzalo v sprievode presnejšie nezaraditel'ných črepov alebo črepov bez výzdoby. Tiež je nutné počítat so skartáciou, preto bolo presnejšie datovanie u väčšiny objektov nemožné. Najväčšia kumulácia objektov je v západnej časti južnej a juhozápadnej časti severnej plochy. To môže byť spôsobené skutočnostou, že východná čast̉ južnej plochy nebola skúmaná tak podrobne ako zvyšok lokality (Geisler 1992, 1-2).

Po preskúmaní rozloženia datovaných objektov (obr. 43) a zvýraznení chát aj zásobníc bolo možné dostatočne preskúmat štruktúru osídlenia (obr. 44). Devät zahíbených chát, zvyšok nadzemnej stavby a dohromady 30 zásobníc tvorí typickú kumulovanú zástavbu, ktorá tvorí akýsi oblúk idúci zo severozápadu a stáčajúci sa na východ. Smerom na východ naberá štruktúra rozptýlený ráz. Z iného uhla pohl'adu však chaty tvoriace na západe polkruh indikujú návesné usporiadanie. Len chata obj. 58 ležala úplne mimo tohto oblúka na severovýchodnom okraji plochy. Rozloženie zásobníc sa zretel’ne sústred'uje v úzkom okolí chát hlavne na západnej strane, čo je na včasnostredovekých sídliskách bežným javom. Smerom na východ sa hustota zásobníc podstatne zmenšovala. Úplne na východnom okraji skúmanej plochy je vidiet tri chaty bez zásobníc, z nich jedna je starohradištná. Zaujímavým javom je zhluk dvoch chát v západnej časti (obj. 79, 101), obe datované do starohradištného obdobia. Tam sa zrejme nachádzalo staré jadro sídliska, ktoré sa následne šírilo smerom na severozápad a východ. Presne medzi spomínanými chatami sa nachádza zhluk siedmich zásobníc (obj. 86, 87, 92, 93, 95, 98, 106). Z nich jedna je spol’ahlivo starohradištná (obj. 92) a jedna z kultúry keramiky pražského typu (obj. 93). Je možné, že obyvatelia chát (obj. 79 a 101) spoločne používali len šest' zásobníc, nakol'ko obj. 93 vzhl'adom k datovaniu do RS1 používat nemohli. Mohlo íst totiž o blízke príbuzenstvo. Ďalej bola zaznamenaná mierna tendencia šírenia osídlenia smerom k severozápadu a „zahustovanie“ spodnej časti oblúka, smerujúceho na východ. Práve tu sa nachádzajú objekty datované do mladších období, konkrétne RS2(2) a RS3. Vzhl’adom k nekompletnému odkryvu však ani toto tvrdenie nestojí na pevných základoch. Je možné predpokladat', že jadro osady tvoril jeden rod. Časom sa na sídlisku mohli usídl'ovat’ nové rodiny, ktoré

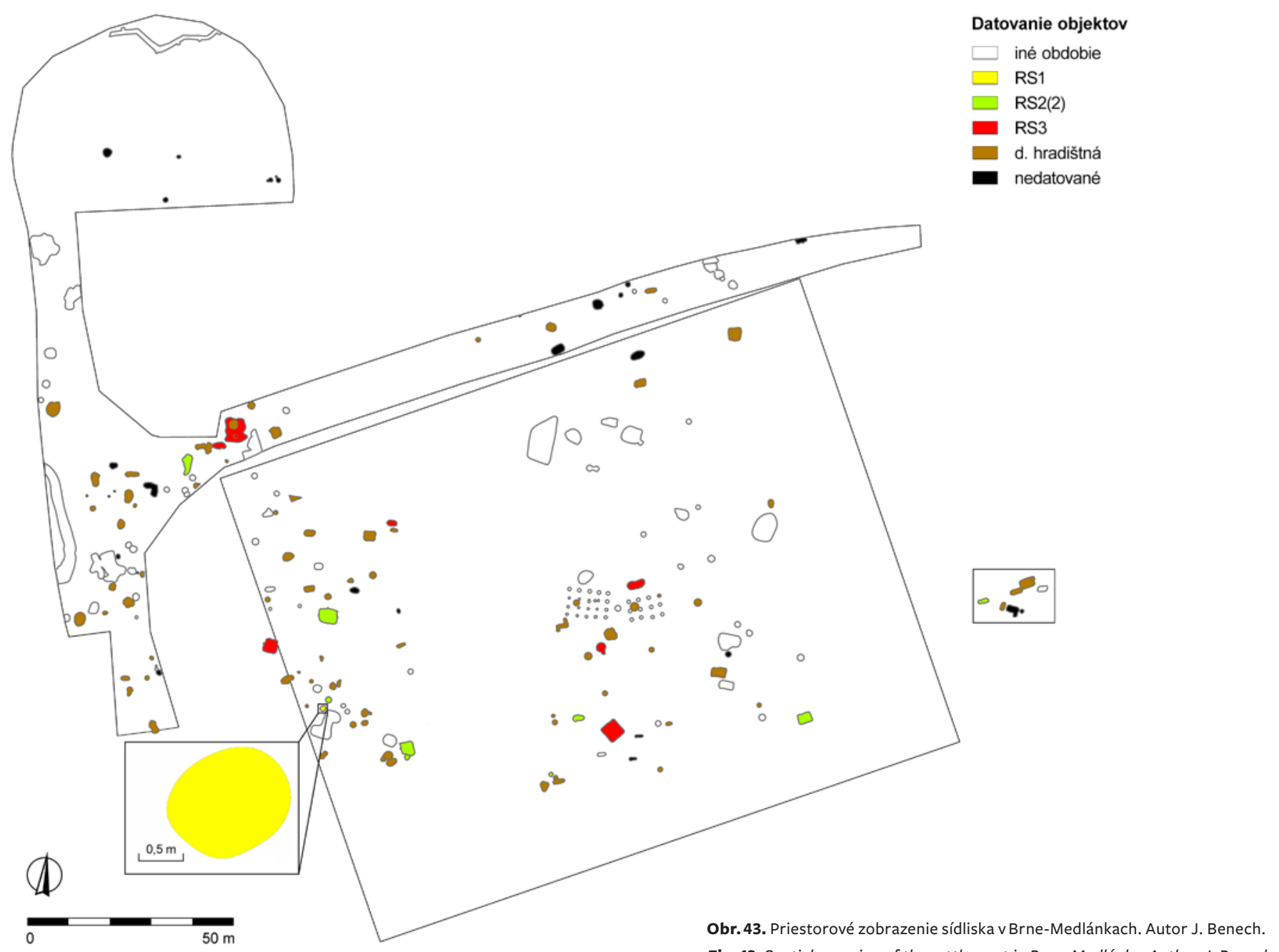

Fig. 43. Spatial mapping of the settlement in Brno-Medlánky. Author J. Benech. 


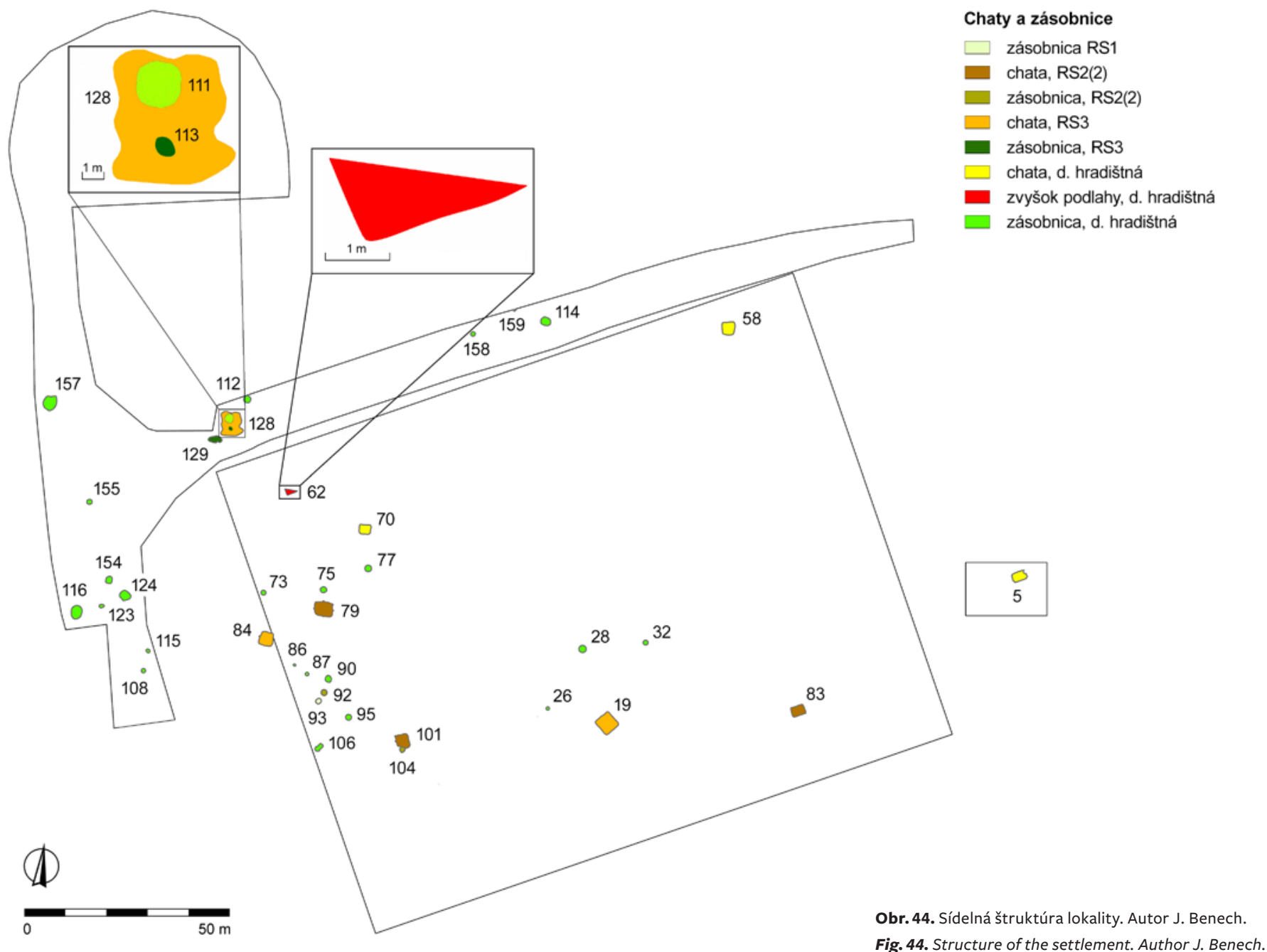

neboli súčastou pôvodného spoločenstva, ale tvorili samostatné rodinné jednotky. Za pozornost' stojí, v porovnaní s ostatnými, väčšia chata s nepravidelným pôdorysom (obj. 128), datovaná do horizontu RS3. Priamo v nej bol zhluk dvoch zásobníc (obj. 111, 113) a hned' vedl'a ležala d'alšia (obj. 129). Zásobnice obj. 113 a 129 boli datované do horizontu RS3, pričom obj. 113 je podl’a dokumentovaného profilu vrstiev mladší. Vzhl’adom $\mathrm{k}$ tomu, že zásobnica 111 bola v chate umiestnená nelogicky a je súčastou kumulácie zásobníc (obj. 111-113, 129), bude s najvyššou pravdepodobnosţou mladšia ako obj. 128 a tiež stredohradištná. To však nemožno tvrdit' s absolútnou istotou. Nakol'ko sa väčšinu objektov nepodarilo datovat', s určitostou nevieme, či chata 128 netvorila záverečnú izolovanú usadlost', alebo existovala až do „konca“ na sídlisku ešte s nejakými obývanými chatami. Vzhl’adom k priestorovému vývoju je reálnejší skôr druhý variant. Otáznik visí tiež nad spomínanou kumuláciou zásobníc (obj. 111-113, 129) a nad výraznými zhlukmi zásobníc na západnej a severozápadnej strane severnej aj južnej plochy. Logicky totiž indikujú prítomnost' d'alších obytných objektov, ktoré sa ale nepodarilo odkryť či už z dôvodu, že ležia mimo skúmanú plochu, alebo boli natol'ko plytké, že ich zničila orba. Ich prítomnost' možno vyvodit aj z viditel'ne väčších vzdialeností medzi chatami v rámci fázy RS2(2) a v rámci horizontu RS3. Medzi chatami 79 a 104 je vzdialenost' asi $50 \mathrm{~m}$, medzi chatami 83 a 104 dokonca až okolo 100 m. Rovnaká situácia je medzi chatami 84 a 128, ktoré sú od seba vzdialené približne $50 \mathrm{~m}$. Vzdialenost' medzi chatami 19 a 84 je asi až 80 m (obr. 44). Vel'kost' týchto vzdialeností je značne netypická. Napríklad na lokalite Březno vzdialenost̉ medzi chatami len zriedka prekročila 20 m (Pleinerová 1975, 24, obr. 2), podobná situácia je aj na lokalite Uherské Hradiště-Sady poloha Kotvice, kde sa vzdialenost medzi chatami pohybuje zväčša len okolo 10 m (Marešová 1985, tab. 4). Nedatované chaty 5 a 58 sú úplne mimo zvyšných chát. Na lokalite taktiež nevidno žiadne náznaky dvorcov či akéhokol'vek štrukturálneho usporiadania, čo sa ale vôbec nevymyká „východoeurópskemu“ vidieckemu prostrediu v ranom stredoveku (Pleinerová 1975, 24-27; Klanica 2008, 222, obr. 125; Milo 2014, 269-293).

Na sídlisku sa tiež nachádzali vyššie spomínané uloženia kompletných zvieracích kostier a kostra človeka pohodená v zásobnici (obj. 112, 124, 157, 159). Všetky osteologické pozostatky boli priestorovo sledované v rámci severnej plochy (obr. 45). Kôň, psy aj kostra človeka sú situované na okraji sídliska, avšak stále relatívne blízko obytného areálu. Vel'ká kumulácia zvieracích kostí v obj. 112, kde sa medzi rôznymi zvieratami objavila zachovalá kostra prasata a psa (Dreslerová 2020, 46-47), sa nachádza doslova vedl'a najsevernejšie položenej chaty. Preto je možné s istotou tvrdit', že bola po tom, čo doslúžila ako zásobnica, používaná ako odpadová jama.

\section{Záver}

Včasnostredoveké sídlisko v Brne-Medlánkach nebolo lokalitou vel'kého regionálneho významu, no napriek tomu obsahovalo mnoho dôležitých informácí́. Ležalo na miernom svahu na sprašovom podloží v úrodnej nížine Medláneckej sníženiny 


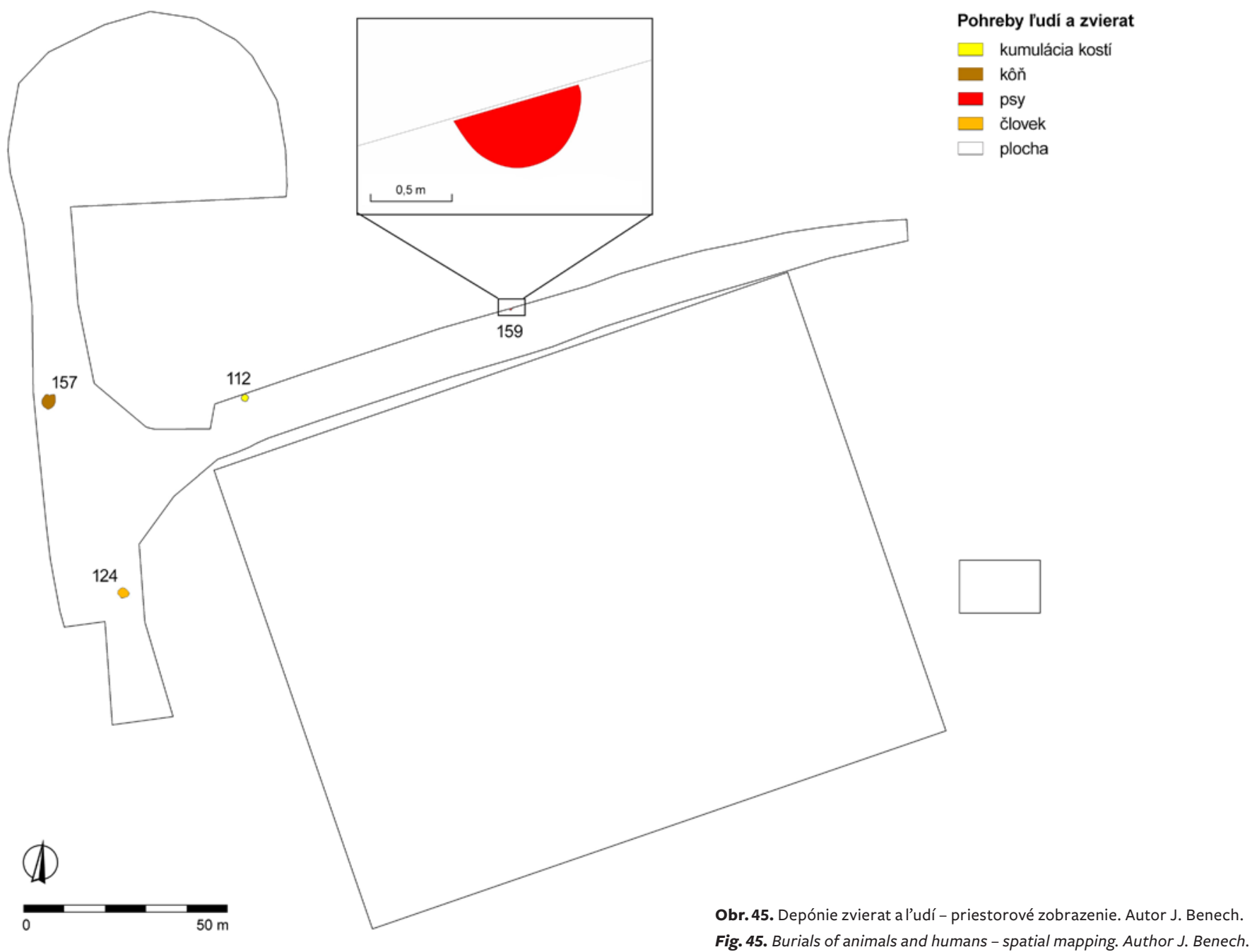

v blízkosti riek Svitavy a Svratky. Úrodné hnedozeme boli ako dnes s najväčšou pravdepodobnost’ou pol'nohospodársky využívané aj vo včasnom stredoveku. Analýza uhlíkov z včasne stredovekých objektov zaradila lokalitu do dubovo-bukového vegetačného stupňa. Na sídlisku bol nájdený zaujímavý a pestrý súbor keramiky od kultúry pražského typu po keramiku stredohradištného obdobia, čo ale neplatí pre ostatné typy nálezov. Keramický súbor umožnil datovat sídlisko od prelomu 6.-7. storočia do 9.-10. storočia a relatívne rozčlenit na horizonty RS1, RS2 a RS3. Horizont RS2 bol vd'aka početnému zastúpeniu keramiky starohradištného obdobia v súbore rozdelený na staršiu a mladšiu fázu. Presnejšie datovat sa podarilo iba 18 objektov (presnejšie datovanie obj. 111 založené na jeho polohe je neisté). Na keramickom súbore sa jasne odrazili konzervatívne tendencie panujúce vo vidieckom prostredí, ktoré sa prejavili hlavne na výzdobe a spôsobe výroby. Na keramike stredohradištného obdobia sa v početných prípadoch nachádzala typická starohradištná výzdoba, keramika bola slabo obtáčaná a okraje zväčša málo profilované. Sídlisko sa v rámci štruktúry a hospodárskej činnosti nijako nelísilo od typického slovanského vidieckeho osídlenia. Na lokalite bolo doložené pol'nohospodárstvo aj chov domácich zvierat. Doložený bol hovädzí dobytok, ošípané, ovce/kozy či hydina. Komunita sa v malej miere venovala aj lovu divej zveri. Realizovalo sa tam podomácke spracovanie koží, kostí a textilu, doložené praslenmi, kostenými preplietačkami a polotovarom kosteného hrotu. Zaujímavé boli doklady drobnej hutníckej výroby v podobe hutníckej trosky a miliera. Aj napriek tomu, že sa sídlisko nachádza relatívne blízko bohatých ložísk železnej rudy v Moravskom krase, nemožno potvrdit', či bola spracovávaná ruda odtial', alebo nie. Na lokalite je príliš málo nálezov na to, aby sa dalo hovorit o väčšej produkcii. Našiel sa ale doklad kováčstva v podobe kováčskej trosky. Až na drobnú metalurgiu nebola na lokalite doložená špecializovaná výroba viazaná na dielne či výrobné areály.

Na sídlisku je spol’ahlivo doložené prosté vidiecke obyvatel'stvo, živiace sa primárne pol'nohospodárstvom. Nálezy, ktoré by dokladali akúkol’vek prítomnoste vyšších elít na sídlisku chýbajú. V súbore keramiky ani v jednom horizonte nebol nájdený žiaden luxusný tovar a výskyt jemného, no zle vypáleného materiálu a rýchleho obtáčania je minimálny. Spoločenské usporiadanie bolo v tomto období a prostredí rodové s kolektívnym/rodovým vlastníctvom pôdy. Komunitu tvorila vel'korodina, prípadne viac spriaznených rodín (Měřínský 2009, 123-127). Usporiadanie sídliska tomu nijak neodporuje (obr. 44). Jeho štruktúra však nebola zachytená v úplnosti, nakol'ko mnohé obytné objekty asi neboli objavené. Na čele celého spoločenstva stála s najväčšou pravdepodobnostou hlava rodiny alebo hlava jednej z rodín. Prítomnosť tohto predáka môže indikovat aj nájdená kostra koňa, ktorý bol asi používaný na jazdenie a mohol patrit práve hierarchicky vyššie postavenej osobe na sídlisku (Dreslerová 2020, 47). Doložená podoba spoločnosti na sídlisku je pre vidiecke prostredie typická (pozri Pleinerová 1975, 105-112). Taktiež boli zistené doklady obchodu na základe nálezov žarnovov. Proveniencia hornín poukazuje na kontakty s oblastou Znojemska. 
Osada mala podl'a zachovaných objektov kumulovaný pôdorys v tvare oblúka, čo je vzhl'adom na skutočnost', že nebola odkrytá celá, diskutabilné. Je možné, že mnohé obytné objekty na lokalite neboli, čo dosvedčujú vel'ké vzdialenosti chát medzi sebou navzájom. Vzhl’adom k mladšiemu datovaniu objektov na východe a severozápade plochy sa osada asi rozširovala týmito smermi. Organizácia domov odhalila iba prítomnostz niekol'kých rodín, ktoré tvorili danú komunitu sídliska. Odkrytých bolo devät zahĺbených chát, zvyšok boli podlahy ako relikt bližšie neurčenej nadzemnej stavby. Na základe malého počtu výpovedných kusov mazanice boli identifikované pletené stavebné konštrukcie, avšak nepodarilo sa ich priradit ku konkrétnym objektom. Štruktúru dotváralo 30 zásobníc, z ktorých väčšina mala typický hruškovitý tvar. Na sídlisku boli tiež objavené depónie zvierat a depónia kostry človeka v zásobných jamách.

O postavení sídliska $v$ priestore Brnenska nemôžeme povedat vel'a. Výroba na lokalite je drobného podomáckeho charakteru, a teda nie je dôvod predpokladat vývoz týchto artiklov. To ale neplatí pre hutníctvo železa. V tomto prípade sa bez dostatočných dôkazov nedá rekonštruovat presný rozsah výroby či zásobovanie okolia touto surovinou. Sídlisko ako celok bolo aj vd’aka hutníckej výrobe v drvivej väčšine hospodársky samostatné, takže tvorilo určitú formu uzavretého spoločenstva. To ale neindikuje absolútnu izoláciu. Na základe prítomnosti derivátov blučinskej keramiky, tiež skleneného korálika z obj. 106 a hrebeňov z chaty obj. 19 a 35, ktoré na sídlisku temer s istotou neboli vyrobené, je predpokladaný kontakt s hradiskom Líšeň-Staré Zámky. Otázkou ale zostáva, či blučinské deriváty pochádzajú z hradiska a prišli ako import, alebo či išlo len o kultúrny vplyv a keramika bola vyrobená na sídlisku. Je teda možné hypoteticky uvažovat’ o lokalite ako o súčasti širšieho pol'nohospodárskeho zázemia tohto regionálneho centra.

\section{Poděkování}

Práca bola podporená projektom MUNI/A/0839/2019 „Archeologické terénní prospekce, exkavace, dokumentace a muzejní prezentace IX“. Touto cestou by som rád pod’akoval R. Procházkovi za vedenie a cenné rady pri písaní tohto článku.

\begin{tabular}{|c|c|c|c|c|c|}
\hline Č. obj. & Rozmery & Híbka & Nálezy & Interpretácia & Datovanie \\
\hline 1 & $\varnothing 85 \mathrm{~cm}$ & $20 \mathrm{~cm}$ & 0 & sídlisková jama & nedatované \\
\hline 3 & $200 \times 140 \mathrm{~cm}$ & $20 \mathrm{~cm}$ & 0 & sídlisková jama & nedatované \\
\hline 4 & $270 \times 140 \mathrm{~cm}$ & $34 \mathrm{~cm}$ & keram. 6 ks, praslen, zv. kosti & sídlisková jama & d. hradištná \\
\hline 5 & $370 \times 330 \mathrm{~cm}$ & $20 \mathrm{~cm}$ & keram. 10 ks, brúsik, klinec, zv. kosti & chata & d. hradištná \\
\hline 6 & $\varnothing 105 \mathrm{~cm}$ & $40 \mathrm{~cm}$ & keram. 2 ks, zv. kosti & sídlisková jama & d. hradištná \\
\hline 7 & $280 \times 130 \mathrm{~cm}$ & $35 \mathrm{~cm}$ & keram. 34 ks, mazanica & sídlisková jama & RS2 \\
\hline 8 & $250 \times 110 \mathrm{~cm}$ & $30 \mathrm{~cm}$ & 0 & sídlisková jama & nedatované \\
\hline 9 & $390 \times 220 \mathrm{~cm}$ & $28 \mathrm{~cm}$ & keram. 32 ks, zv. kosti, uhlíky & sídlisková jama & d. hradištná \\
\hline 11 & $110 \times 90 \mathrm{~cm}$ & $30 \mathrm{~cm}$ & keram. 1 ks, zv. kosti & sídlisková jama & d. hradištná \\
\hline 14 & $150 \times 90 \mathrm{~cm}$ & $65 \mathrm{~cm}$ & keram. 22 ks, mazanica, uhlíky, zv. kosti, praslen & sídlisková jama & d. hradištná \\
\hline 16 & $180 \times 80 \mathrm{~cm}$ & $30 \mathrm{~cm}$ & 0 & sídlisková jama & nedatované \\
\hline 17 & $180 \times 70 \mathrm{~cm}$ & $20 \mathrm{~cm}$ & 0 & sídlisková jama & nedatované \\
\hline 18 & $\varnothing 120 \mathrm{~cm}, \varnothing \mathrm{dna} 60 \mathrm{~cm}$ & $120 \mathrm{~cm}$ & keram. 2 ks, zv. kosti & zásobnica & d. hradištná \\
\hline 19 & $440 \times 400 \mathrm{~cm}$ & $15-50 \mathrm{~cm}$ & $\begin{array}{l}\text { keram. } 48 \text { ks, mazanica, kostený hrot, hrebeň, zv. } \\
\text { kosti, uhlíky }\end{array}$ & chata & RS3 \\
\hline 20 & $210 \times 175 \mathrm{~cm}$ & $68 \mathrm{~cm}$ & keram. 17 ks, zv. kosti & sídlisková jama & d. hradištná \\
\hline 21 & $\varnothing 110 \mathrm{~cm}, \varnothing \mathrm{dna} 120 \mathrm{~cm}$ & $190 \mathrm{~cm}$ & keram. 27 ks, brúsik, zv. kosti, uhlíky & milier & RS2(2) \\
\hline 22 & $130 \times 95 \mathrm{~cm}$ & $28 \mathrm{~cm}$ & keram. 2 ks, zv. kosti & sídlisková jama & d. hradištná \\
\hline 23 & $340 \times 110 \mathrm{~cm}$ & $20-42 \mathrm{~cm}$ & keram. 5 ks, zv. kosti & sídlisková jama & d. hradištná \\
\hline 24 & $280 \times 150 \mathrm{~cm}$ & $18 \mathrm{~cm}$ & keram. $26 \mathrm{ks}$ & sídlisková jama & RS2(2) \\
\hline 25 & $\varnothing 95 \mathrm{~cm}$ & $24 \mathrm{~cm}$ & keram. 3 ks, zv. kosti & sídlisková jama & d. hradištná \\
\hline 26 & $\varnothing 130 \mathrm{~cm}$ & $120 \mathrm{~cm}$ & keram. 2 ks, zv. kosti & zásobnica & d. hradištná \\
\hline 27 & $\varnothing 125 \mathrm{~cm}, \varnothing \mathrm{dna} 45 \mathrm{~cm}$ & $134 \mathrm{~cm}$ & keram. 18 ks, mazanica, zv. kosti & sídlisková jama & d. hradištná \\
\hline 28 & $\varnothing 180 \mathrm{~cm}$ & $200 \mathrm{~cm}$ & keram. 7 ks, zv. kosti, ulity & zásobnica & d. hradištná \\
\hline 30 & $232 \times 306 \mathrm{~cm}$ & $68 \mathrm{~cm}$ & keram. 23 ks, zv. kosti & sídlisková jama & RS3 \\
\hline 31 & $310 \times 247 \mathrm{~cm}$ & $64 \mathrm{~cm}$ & keram. 13 ks, mazanica, zv. kosti, uhlíky & sídlisková jama & d. hradištná \\
\hline 32 & $\varnothing 134 \mathrm{~cm}, \varnothing \mathrm{dna} 92 \mathrm{~cm}$ & $170 \mathrm{~cm}$ & keram. 30 ks, mazanica, zv. kosti, uhlíky & zásobnica & d. hradištná \\
\hline 33 & $\varnothing 200 \mathrm{~cm}, \varnothing \mathrm{dna} 150 \mathrm{~cm}$ & $90 \mathrm{~cm}$ & keram. 12 ks, zv. kosti, uhlíky & sídlisková jama & d. hradištná \\
\hline 34 & $170 \times 145 \mathrm{~cm}$, dno $80 \times 56 \mathrm{~cm}$ & $76 \mathrm{~cm}$ & keram. 6 ks, zv. kosti & sídlisková jama & d. hradištná \\
\hline 35 & $248 \times 106 \mathrm{~cm}$ & $25 \mathrm{~cm}$ & keram. 21 ks, hrebeň, zv. kosti & sídlisková jama & d. hradištná \\
\hline 36 & $\varnothing 33 \mathrm{~cm}$ & $28 \mathrm{~cm}$ & keram. 4 ks & sídlisková jama & d. hradištná \\
\hline 37 & $146 \times 170 \mathrm{~cm}$ & $40 \mathrm{~cm}$ & keram. 6 ks, brúsik, zv. kosti & sídlisková jama & d. hradištná \\
\hline 38 & $\varnothing 148 \mathrm{~cm}, \varnothing \mathrm{dna} 152 \mathrm{~cm}$ & $34 \mathrm{~cm}$ & 0 & sídlisková jama & nedatované \\
\hline 44 & $340 \times 140 \mathrm{~cm}$ & $30-40 \mathrm{~cm}$ & keram. 39 ks, zv. kosti, uhlíky & sídlisková jama & RS3 \\
\hline 53 & $210 \times 130 \mathrm{~cm}$ & $20 \mathrm{~cm}$ & keram. 4 ks, zv. kosti & sídlisková jama & d. hradištná \\
\hline 55 & $320 \times 175 \mathrm{~cm}$ & $40 \mathrm{~cm}$ & keram. 13 ks, zv. kosti, ulity & sídlisková jama & d. hradištná \\
\hline 57 & $440 \times 120 \mathrm{~cm}$ & - & 0 & sídlisková jama & nedatované \\
\hline 58 & $300 \times 312 \mathrm{~cm}$ & $30 \mathrm{~cm}$ & keram. 36 ks, mazanica, zv. kosti, uhlíky & chata & d. hradištná \\
\hline 62 & - & - & keram. 3 ks, zv. Kosti, praslen & zvyšok podlahy & d. hradištná \\
\hline 63 & $\varnothing 106 \mathrm{~cm}$ & $18 \mathrm{~cm}$ & keram. 2 ks, zv. kosti & sídlisková jama & d. hradištná \\
\hline 65 & $230 \times 132 \mathrm{~cm}$ & $50 \mathrm{~cm}$ & keram. 59 ks, železo, zv. kosti, uhlíky & sídlisková jama & RS3 \\
\hline 66 & $158 \times 75 \mathrm{~cm}$ & $30 \mathrm{~cm}$ & keram. 3 ks, zv. kosti & sídlisková jama & d. hradištná \\
\hline 68 & $266 \times 168 \mathrm{~cm}$ & $16-34 \mathrm{~cm}$ & keram. 5 ks, zv. kosti & sídlisková jama & d. hradištná \\
\hline
\end{tabular}




\begin{tabular}{|c|c|c|c|c|c|}
\hline Č. obj. & Rozmery & Híbka & Nálezy & Interpretácia & Datovanie \\
\hline 69 & $266 \times 148 \mathrm{~cm}$ & $45 \mathrm{~cm}$ & keram. 4 ks, zv. kosti, uhlíky & sídlisková jama & d. hradištná \\
\hline 70 & $280 \times 240 \mathrm{~cm}$ & $0-16 \mathrm{~cm}$ & keram. 14 ks, mazanica, zv. kosti & chata & d. hradištná \\
\hline 71 & $214 \times 160 \mathrm{~cm}$ & $20 \mathrm{~cm}$ & keram. 3 ks, zv. kosti & sídlisková jama & d. hradištná \\
\hline 73 & $\varnothing 84-140 \mathrm{~cm}, \varnothing$ dna $48 \mathrm{~cm}$ & $232 \mathrm{~cm}$ & keram. 7 ks, žarnov, ulity, uhlíky & zásobnica & d. hradištná \\
\hline 74 & $256 \times 150 \mathrm{~cm}$ & $26 \mathrm{~cm}$ & keram. 7 ks, zv. kosti & sídlisková jama & d. hradištná \\
\hline 75 & $\varnothing 160-180 \mathrm{~cm}, \varnothing$ dna $50 \mathrm{~cm}$ & $220 \mathrm{~cm}$ & keram. 14 ks, zv. kosti & zásobnica & d. hradištná \\
\hline 76 & $150 \times 100 \mathrm{~cm}$ & $40 \mathrm{~cm}$ & keram. 8 ks, zv. kosti & sídlisková jama & d. hradištná \\
\hline 77 & $\varnothing 130 \mathrm{~cm}, \varnothing \mathrm{dna} 70 \mathrm{~cm}$ & $170 \mathrm{~cm}$ & keram. 5 ks, zv. kosti & zásobnica & d. hradištná \\
\hline 78 & $220 \times 120 \mathrm{~cm}$ & $25 \mathrm{~cm}$ & 0 & sídlisková jama & nedatované \\
\hline 79 & $360 \times 330 \mathrm{~cm}$ & $16 \mathrm{~cm}$ & $\begin{array}{l}\text { keram. } 45 \text { ks, železný nôž, brúsik, zv. kosti, ulity, } \\
\text { uhlíky }\end{array}$ & chata & $\mathrm{RS} 2(2)$ \\
\hline 80 & $116 \times 90 \mathrm{~cm}$ & $50 \mathrm{~cm}$ & 0 & sídlisková jama & nedatované \\
\hline 81 & $230 \times 122 \mathrm{~cm}$ & $24 \mathrm{~cm}$ & keram. 4 ks, zv. kosti & sídlisková jama & d. hradištná \\
\hline 83 & $338 \times 300(\mathrm{~V}$ stena $240 \mathrm{~cm})$ & $20-38 \mathrm{~cm}$ & keram. 33 ks, zv. kosti, uhlíky & chata & $\operatorname{RS} 2(2)$ \\
\hline 84 & $364 \times 326 \mathrm{~cm}$ & $20-45 \mathrm{~cm}$ & keram. 12 ks, zv. kosti & chata & RS3 \\
\hline 85 & $338 \times 180 \mathrm{~cm}$ & $28-66 \mathrm{~cm}$ & keram. 16 ks, zv. kosti & sídlisková jama & d. hradištná \\
\hline 86 & $\varnothing 72 \mathrm{~cm}, \varnothing \mathrm{dna} 40 \mathrm{~cm}$ & $210 \mathrm{~cm}$ & keram. 13 ks, žarnov, zv. kosti, mazanica, uhlíky & zásobnica & d. hradištná \\
\hline 87 & $\varnothing 84 \mathrm{~cm}, \varnothing \mathrm{dna} 34 \mathrm{~cm}$ & $120 \mathrm{~cm}$ & keram. 14 ks, pražnica, zv. kosti & zásobnica & d. hradištná \\
\hline 89 & $120 \times 80 \mathrm{~cm}$ & $8 \mathrm{~cm}$ & keram. 2 ks & sídlisková jama & d. hradištná \\
\hline 90 & $\varnothing 170 \mathrm{~cm}, \varnothing \mathrm{dna} 110 \mathrm{~cm}$ & $145 \mathrm{~cm}$ & keram. 27 ks, mazanica, žarnov, zv. kosti & zásobnica & d. hradištná \\
\hline 91 & $190 \times 114 \mathrm{~cm}$ & $25 \mathrm{~cm}$ & keram. 8 ks, zv. Kosti, praslen & sídlisková jama & d. hradištná \\
\hline 92 & $\varnothing 150 \mathrm{~cm}, \varnothing \mathrm{dna} 70 \mathrm{~cm}$ & $232 \mathrm{~cm}$ & keram. 27 ks, zv. kosti & zásobnica & $\mathrm{RS} 2(2)$ \\
\hline 93 & $\varnothing 166 \mathrm{~cm}, \varnothing \mathrm{dna} 42 \mathrm{~cm}$ & $190 \mathrm{~cm}$ & keram. 28 ks, zv. kosti, ulity, uhlíky & zásobnica & RS1 \\
\hline 94 & $\varnothing 84 \mathrm{~cm}$ & $20 \mathrm{~cm}$ & keram. 1 ks & sídlisková jama & d. hradištná \\
\hline 95 & $\varnothing 140 \mathrm{~cm}$ & $180 \mathrm{~cm}$ & keram. 19 ks, žarnov, zv. kosti, uhlíky & zásobnica & d. hradištná \\
\hline 98 & - & - & keram. 41 ks, zv. kosti & sídlisková jama & d. hradištná \\
\hline $98 \mathrm{~A}$ & $200 \times 210 \mathrm{~cm}$ & $36-45 \mathrm{~cm}$ & keram. 3 ks, zv. kosti & sídlisková jama & d. hradištná \\
\hline $98 \mathrm{~B}$ & $180 \times 130 \mathrm{~cm}$ & $40 \mathrm{~cm}$ & zv. kosti & sídlisková jama & d. hradištná \\
\hline 99 & $\varnothing 134 \mathrm{~cm}, \varnothing \mathrm{dna} 65 \mathrm{~cm}$ & $130 \mathrm{~cm}$ & keram. 18 ks, mazanica, zv. kosti, ulity, uhlíky & sídlisková jama & d. hradištná \\
\hline 101 & $300 \times 280 \mathrm{~cm}$ & $30 \mathrm{~cm}$ & keram. 44 ks, mazanica, zv. kosti, uhlíky & chata & $\operatorname{RS} 2(2)$ \\
\hline 102 & $260 \times 150 \mathrm{~cm}$ & $15 \mathrm{~cm}$ & keram. 2 ks, mazanica, zv. kosti & sídlisková jama & d. hradištná \\
\hline 103 & - & - & keram. 5 ks, zv. kosti & sídlisková jama & d. hradištná \\
\hline $103 \mathrm{~A}$ & $\varnothing 100 \mathrm{~cm}, \varnothing \mathrm{dna} 100 \mathrm{~cm}$ & $80 \mathrm{~cm}$ & keram. 3 ks, zv. kosti & sídlisková jama & d. hradištná \\
\hline $103 \mathrm{~B}$ & $170 \times 140 \mathrm{~cm}$ & $55-86 \mathrm{~cm}$ & zv. kosti & sídlisková jama & d. hradištná \\
\hline 104 & $\varnothing 110 \mathrm{~cm}$ & $220 \mathrm{~cm}$ & keram. 37 ks, zv. kosti, ulity, uhlíky & zásobnica & $\mathrm{RS} 2(2)$ \\
\hline 106 & $\varnothing 115 \mathrm{~cm}, \varnothing \mathrm{dna} 43-60 \mathrm{~cm}$ & $246 \mathrm{~cm}$ & $\begin{array}{l}\text { keram. } 45 \text { ks, sklo, brúsik, žarnov, zv. kosti, ulity, } \\
\text { uhlíky }\end{array}$ & zásobnica & d. hradištná \\
\hline $107(508 / 109)$ & $210 \times 108 \mathrm{~cm}$ & $16 \mathrm{~cm}$ & keram. $1 \mathrm{ks}$ & sídlisková jama & d. hradištná \\
\hline $108(509 / 110)$ & $\varnothing 105 \mathrm{~cm}, \varnothing$ dna $130 \mathrm{~cm}$ & $130 \mathrm{~cm}$ & keram. 35 ks, zv. kosti & zásobnica & d. hradištná \\
\hline $109(574 / 175)$ & $390 \times 270 \mathrm{~cm}$ & $55 \mathrm{~cm}$ & keram. 18 ks, mazanica, 2 kostené hroty & sídlisková jama & d. hradištná \\
\hline $110(580 / 181)$ & $270 \times 260 \mathrm{~cm}$ & $30 \mathrm{~cm}$ & keram. 5 ks, uhlíky & sídlisková jama & d. hradištná \\
\hline $111(583 / 184)$ & $\varnothing 200 \mathrm{~cm}, \varnothing \mathrm{dna} 10 \mathrm{~cm}$ & $270 \mathrm{~cm}$ & keram. 12 ks, zv. kosti, ulity & zásobnica & d. hradištná \\
\hline $112(578 / 179)$ & $\varnothing 180 \mathrm{~cm}, \varnothing \mathrm{dna} 55 \mathrm{~cm}$ & $200 \mathrm{~cm}$ & keram. 15 ks, zv. kosti, ulity, žarnov & zásobnica & d. hradištná \\
\hline $113(582 / 183)$ & $\varnothing 80 \mathrm{~cm}, \varnothing \mathrm{dna} 40 \mathrm{~cm}$ & $260 \mathrm{~cm}$ & keram. 54 ks, troska, zv. kosti, ulity & zásobnica & RS3 \\
\hline $114(556 / 157)$ & $\varnothing 250 \mathrm{~cm}, \varnothing$ dna $50 \mathrm{~cm}$ & $240 \mathrm{~cm}$ & keram. 7 ks, mazanica, žarnov, zv. kosti, ulity & zásobnica & d. hradištná \\
\hline $115(507 / 108)$ & $\varnothing 105 \mathrm{~cm}, \varnothing \mathrm{dna} 92 \mathrm{~cm}$ & $220 \mathrm{~cm}$ & keram. 1 ks, zv. kosti & zásobnica & d. hradištná \\
\hline $116(511 / 112)$ & $\varnothing 340 \mathrm{~cm}, \varnothing \mathrm{dna} 120 \mathrm{~cm}$ & $240 \mathrm{~cm}$ & keram. 1 ks, uhlíky & zásobnica & d. hradištná \\
\hline $118(552 / 153)$ & $290 \times 120 \mathrm{~cm}$ & $30 \mathrm{~cm}$ & keram. 3 ks, zv. kosti & sídlisková jama & d. hradištná \\
\hline $119(529 / 130)$ & $320 \times 210 \mathrm{~cm}$ & $30 \mathrm{~cm}$ & keram. 1 ks & sídlisková jama & d. hradištná \\
\hline $120(503 / 104)$ & $145 \times 155 \mathrm{~cm}$ & $22 \mathrm{~cm}$ & keram. 3 ks & sídlisková jama & nedatované \\
\hline $121(576 / 177)$ & $\varnothing 65 \mathrm{~cm}, \varnothing \mathrm{dna} 40 \mathrm{~cm}$ & $40 \mathrm{~cm}$ & keram. $2 \mathrm{ks}$ & kôlová jamka & d. hradištná \\
\hline $122(536 / 137)$ & $340 \times 120 \mathrm{~cm}$ & $20 \mathrm{~cm}$ & keram. 9 ks, mazanica, zv. kosti & sídlisková jama & d. hradištná \\
\hline $123(516 / 117)$ & $\varnothing 125 \mathrm{~cm}, \varnothing$ dna $90 \mathrm{~cm}$ & $225 \mathrm{~cm}$ & keram. 1 ks, zv. kosti, uhlíky & zásobnica & d. hradištná \\
\hline $124(513 / 114)$ & $240 \times 220 \mathrm{~cm}$ & $220 \mathrm{~cm}$ & keram. 3 ks, zv. kosti, l'udská kostra & zásobnica & d. hradištná \\
\hline $125(572 / 173)$ & $165 \times 110 \mathrm{~cm}$ & $60 \mathrm{~cm}$ & keram. 9 ks, mazanica, zv. kosti & sídlisková jama & d. hradištná \\
\hline $126(540 / 141)$ & $145 \times 110 \mathrm{~cm}$ & $50 \mathrm{~cm}$ & keram. 3 ks & sídlisková jama & d. hradištná \\
\hline $127(537 / 138)$ & $350 \times 210 \mathrm{~cm}$ & $50 \mathrm{~cm}$ & keram. 9 ks, zv. kosti & sídlisková jama & d. hradištná \\
\hline $128(577 / 178)$ & $500 \times 550 \mathrm{~cm}$ & $100 \mathrm{~cm}$ & $\begin{array}{l}\text { keram. } 100 \text { ks, Fe, mazanica, zv. kosti, uhlíky, } \\
\text { ulity, } 2 \text { kostené hroty }\end{array}$ & chata & RS3 \\
\hline $129(575 / 176)$ & $300 \times 160 \mathrm{~cm}$ & $70-270 \mathrm{~cm}$ & keram. 69 ks, zv. kosti, kostený hrot & zásobnica & RS3 \\
\hline $130(573 / 174)$ & $520 \times 240 \mathrm{~cm}$ & $35 \mathrm{~cm}$ & $\begin{array}{l}\text { keram. } 39 \text { ks, Fe, Ki, Bi, praslen, mazanica, zv. } \\
\text { kosti, } 2 \text { kostené hroty }\end{array}$ & sídlisková jama & $\mathrm{RS} 2(2)$ \\
\hline $131(526 / 127)$ & $230 \times 170 \mathrm{~cm}$ & $20 \mathrm{~cm}$ & keram. 1 ks, zv. kosti & sídlisková jama & d. hradištná \\
\hline $133(549 / 150)$ & $290 \times 120 \mathrm{~cm}$ & $15 \mathrm{~cm}$ & keram. 1 ks & sídlisková jama & nedatované \\
\hline $134(522 / 123)$ & $120 \times 100 \mathrm{~cm}$ & $35 \mathrm{~cm}$ & 0 & sídlisková jama & nedatované \\
\hline $135(523 / 124)$ & $56 \times 50 \mathrm{~cm}$ & $10 \mathrm{~cm}$ & 0 & kôlová jamka & nedatované \\
\hline
\end{tabular}




\begin{tabular}{|c|c|c|c|c|c|}
\hline Č. obj. & Rozmery & Híbka & Nálezy & Interpretácia & Datovanie \\
\hline $136(530 / 131)$ & $340 \times 350 \mathrm{~cm}$ & $20 \mathrm{~cm}$ & 0 & sídlisková jama & nedatované \\
\hline $137(532 / 133)$ & $50 \times 44 \mathrm{~cm}$ & $12 \mathrm{~cm}$ & 0 & kôlová jamka & nedatované \\
\hline $138(533 / 134)$ & $52 \times 44 \mathrm{~cm}$ & $26 \mathrm{~cm}$ & 0 & kôlová jamka & nedatované \\
\hline $139(534 / 135)$ & $50 \times 40 \mathrm{~cm}$ & $10 \mathrm{~cm}$ & 0 & kôlová jamka & nedatované \\
\hline $140(539 / 140)$ & $200 \times 150 \mathrm{~cm}$ & $20-100 \mathrm{~cm}$ & 0 & sídlisková jama & nedatované \\
\hline $142(554 / 155)$ & $115 \times 85 \mathrm{~cm}$ & $40 \mathrm{~cm}$ & 0 & sídlisková jama & nedatované \\
\hline $143(555 / 156)$ & $110 \times 60 \mathrm{~cm}$ & $26 \mathrm{~cm}$ & 0 & sídlisková jama & nedatované \\
\hline $144(562 / 163)$ & $\varnothing 250 \mathrm{~cm}$ & $60 \mathrm{~cm}$ & mazanica, Bi & sídlisková jama & nedatované \\
\hline $145(563 / 164)$ & $340 \times 210 \mathrm{~cm}$ & $80 \mathrm{~cm}$ & 0 & sídlisková jama & nedatované \\
\hline $146(564 / 165)$ & $\varnothing 220 \mathrm{~cm}, \varnothing \mathrm{dna} 70 \mathrm{~cm}$ & $100 \mathrm{~cm}$ & 0 & sídlisková jama & nedatované \\
\hline $147(565 / 166)$ & $\varnothing 120 \mathrm{~cm}, \varnothing \mathrm{dna} 75 \mathrm{~cm}$ & $30 \mathrm{~cm}$ & 0 & sídlisková jama & nedatované \\
\hline $148(566 / 167)$ & $\varnothing 95 \mathrm{~cm}, \varnothing \mathrm{dna} 70 \mathrm{~cm}$ & $15 \mathrm{~cm}$ & 0 & sídlisková jama & nedatované \\
\hline $149(567 / 168)$ & $\varnothing 110 \mathrm{~cm}, \varnothing \mathrm{dna} 50 \mathrm{~cm}$ & $50 \mathrm{~cm}$ & 0 & pec & nedatované \\
\hline $150(568 / 169)$ & $\varnothing 110 \mathrm{~cm}, \varnothing \mathrm{dna} 60 \mathrm{~cm}$ & $30-38 \mathrm{~cm}$ & 0 & pec & nedatované \\
\hline $152(505 / 106)$ & $225 \times 140 \mathrm{~cm}$ & $60-85 \mathrm{~cm}$ & keram. ?, zv. kosti & sídlisková jama & d. hradištná \\
\hline $154(517 / 118)$ & $\varnothing 180 \mathrm{~cm}, \varnothing$ dna $130 \mathrm{~cm}$ & $235 \mathrm{~cm}$ & 0 & zásobnica & d. hradištná \\
\hline $155(528 / 129)$ & $\varnothing 135 \mathrm{~cm}, \varnothing \mathrm{dna} 60 \mathrm{~cm}$ & $260 \mathrm{~cm}$ & 0 & zásobnica & d. hradištná \\
\hline $156(535 / 136)$ & $90 \times 75 \mathrm{~cm}$ & $25 \mathrm{~cm}$ & keram. ? & sídlisková jama & d. hradištná \\
\hline $157(541 / 142)$ & $330 \times 340 \mathrm{~cm}$ & $200-280 \mathrm{~cm}$ & kostra koňa & zásobnica & d. hradištná \\
\hline $158(557 / 158)$ & $\varnothing 110 \mathrm{~cm}, \varnothing$ dna $110 \mathrm{~cm}$ & $190 \mathrm{~cm}$ & 0 & zásobnica & d. hradištná \\
\hline $159(558 / 159)$ & $\varnothing 80 \mathrm{~cm}, \varnothing \mathrm{dna} 90 \mathrm{~cm}$ & $250 \mathrm{~cm}$ & zv. kosti & zásobnica & d. hradištná \\
\hline
\end{tabular}

Tab. 22. Katalóg objektov.

Tab. 22. Catalogue of features.

\section{Literatura}

Balcárková, A. 2010: Raně středověké osídlení na lokalitě Olomouc-Slavonín, „Horní lán“. Přrehled výzkumů 51, 157-196. Dostupné tiež z: https://www.arub.cz/prehled-vydanych-cisel/PV51_studie_10.pdf.

Bartošková, A. 2003: Kostěná a parohová industrie ze Staré Boleslavi. In: I. Boháčová (ed.): Stará Boleslav - Přemyslovský hrad v raném středověku. Mediaevalia archaeologica 5. Praha: Archeologický ústav Akademie věd České republiky, 227-266.

Berková, Z., Parma, D. 2013: Sídelní areály mladší a pozdní doby bronzové v Brně-Medlánkách a Brně-Řečkovicích. Pravěk Nová řada 21, 71-152.

Braun, V., Fuchs, K. 1992: Přírodní podmínky a vývoj zemědělství v Medlánkách. In: Medlánky (1237-1992). Brno-Medlánky: Obecní úřad, 8-17.

Březinová, H., Přichystalová, R. 2014: Úvahy o textilní výrobě na Pohansku na základě analýzy nálezů textilních fragmentů a předmětů souvisejících se spřádáním a tkaním. Památky archeologické CV, 155-214. Dostupné tiež z: https://1url.cz/jKU7I.

Buček, A., Kirchner, K. 2011: Krajina města Brna. In: R. Procházka (ed.): Dějiny Brna 1. Brno: Statutární město Brno, Archiv města Brna, 41-81.

Bursák, D., Kacl, P., Trojánková O., Zavřel, J. 2018: Hutnictví železa v industriální osadě v Praze-Bubenči. Příklad dílny z doby římské z Papírenské ulice. Archaeologica Pragensia 24, 363-408.

Cnotliwy, E. 1973: Rzemioslo rogownicze na Pomorzu wczesnośredniowiecznym. Wrocław: Zakład Narodowy im. Ossolińskich.

Čechura, M. 2010: Pohřební ritus ve středověku a novověku ve světle archeologického a antropologického výzkumu. Archaeologia historica 35(1-2), 111-120. Dostupné tiež z: https://digilib.phil.muni.cz/handle/11222.digilib/128141.

ČGS-Půdy: Půdní mapa 1: 50000 [online]. Praha: Česká geologická služba [cit. 2018-05-17]. Dostupné z: https://mapy.geology.cz/pudy/.

Čižmářová, J. 1996: Sídliště ze starší doby hradištní v Brně-Starém Lískovci. Pravěk Nová řada 1994/4, 271-288.

ČÚZK-Data200: Mapový podklad - Data200 [online]. [cit. 2021-10-20]. (c) Český úřad zeměměřický a katastrální. Dostupné z: https://ags.cuzk.cz/geoprohlizec/?p=22520.
Dostál, B. 1975: Břreclav-Pohansko IV. Velmožský dvorec. Brno: Universita J. E. Purkyně.

Dostál, B. 1987: Stavební kultura Slovanů 6.-9. století na území ČSSR. Archaeologia historica 12, 9-32. Dostupné tiež z: http://hdl.handle.net/11222.digilib/139683.

Dreslerová, G. 2020: Zvířecí kosti a kostry ze slovanského sídliště v Brně-Medlánkách. Přehled výzkumů 61(2), 43-52. Dostupné tiež z: http://pv.arub.avcr.cz/61_2_02.pdf.

Drozdová, E., Šedo, O. 2004: Úvodní informace o objektu 6/86 s pohozenými lidskými a zvířecími kostrami z doby velkomoravské v Letonicích. In: V. Hašek, R. Nekuda, M. Ruttkay (eds.): Ve službách archeologie V. Sborník $k$ sedmdesátinám RNDr. Emanuela Opravila, CSc. Brno, Nitra: Muzejní a vlastivědná společnost v Brně, Geodrill, Archeologický ústav SAV, 223-235.

Dynda, J. 2016: Slovanská hippomancie: Koňský divinační rituál jako mediátor v symbolické soustavě slovanského pohanství. Studia mythologica slavica 19, 61-85.

Fojtík, P., Maleček, M., Maleček, R. 2007: Brno (k. ú. Líšeň, okr. Brno-město). Přrehled výzkumů 48, 462-463. Dostupné tiež z: https://www.arub.cz/magazine/pv-48/.

Galuška, L. 1989: Plastická lišta na středohradištní keramice ze Starého Města. Acta Musei Moraviae, Scientiae sociales LXXIV, 121-135.

Geisler, M. 1987: Záchranný výzkum v Brně -Medlánkách (okr. Brno-město). Přehled výzkumů 1984, 74-75. Dostupné tiež z: https://www.arub.cz/magazine/pv-29/.

Geisler, M. 1992: Brno-Medlánky. Rkp. Nálezové zprávy MTX199201450 [cit. 2021-11-19]. Uloženo: Archiv nálezových zpráv Archeologického ústavu AV ČR, Brno, v. v. i. Dostupné tiež z: Digitální archiv Archeologické mapy https://digiarchiv.aiscr.cz/ id/M-TX-199201450.

Geisler, M. 2008a: Brno Královo Pole-Medlánky. Rkp. Nálezové zprávy MTX201602248 [cit. 2021-11-19]. Uloženo: Archiv nálezových zpráv Archeologického ústavu AV ČR, Brno, v. v. i. Dostupné tiež z: Digitální archiv Archeologické mapy https://digiarchiv.aiscr.cz/id/M-TX-201602248. 
Geisler, M. 2008b: Brno (k. ú. Královo Pole a Medlánky, okres Brno-město). Přehled výzkumů 49, 393-394. Dostupné tiež z: https://www.arub.cz/wp-content/uploads/pv_49_2007_ stredovek_a_novovek.pdf.

Geislerová, K., Parma, D. (eds.) 2013: Výskumy - Ausgrabungen 2005-2010. Brno: Ústav archeologické památkové péče Brno.

Gregerová, M. 2010: Petroarcheologie keramiky v historické minulosti Moravy a Slezska. Brno: Masarykova univerzita.

Hrubý, V. 1957: Slovanské kostěné předměty a jejich výroba na Moravě. Památky archeologické XLVIII, 118-217. Dostupné tiež z: https://1url.cz/nKftO.

Hrubý, V. 1961: Staroslovanské Brno. Brno v minulosti a dnes III, 130-140.

Jelínková, D. 1990: K chronologii sídlištních nálezů s keramikou pražského typu na Moravě. In: V. Nekuda, J. Unger, M. Čižmář (eds.): Pravěké a slovanské osídlení Moravy. Sborník k 80. nar. Josefa Poulíka. Brno: Muzejní a vlastivědná společnost, Archeologický ústav ČSAV, 251-281.

Kalčík, L. 2015: Povelkomoravské osídlení hradiska Staré zámky u Líšně. Přehled výzkumů 56(2), 127-200. Dostupné tiež z: https://www.arub.cz/prehled-vydanych-cisel/PV56_2_studie_4_ Kalcik.pdf.

Kavánová, B. 1995: Knochen- und Geweihindustrie in Mikulčice. In: L. Poláček, F. Daim (Hrsg.): Studien zum Burgwall von Mikulčice I. Spisy Archeologického ústavu AV ČR Brno 2. Brno: Archäologisches Institut der Akademie der Wissenschaften der Tschechischen Republik, Brno, 113-378.

Klanica, Z. 2008: Mutěnice-Zbrod. Zaniklé slovanské sídliště ze 7.-10. století. Spisy Archeologického ústavu AV ČR Brno 36. Brno: Archeologický ústav Akademie věd České republiky.

Klíma, B. 1975: Rozbor hřebů z velkomoravského hradiště v Mikulčicích. Archeologické rozhledy XXVII(2), 40-150.

Kmošek, J. 2011: Experimentální pálení dřevěného uhlí v jamách. Archeologia technica 22, 11-44.

Krajíc, R. 2003: Sezimovo Ústí - Archeologie středověkého poddanského města 3. Díl 1. Kovárna v Sezimově Ústí a anylýza výrobků ze železa. Praha, Sezimovo Ústí, Tábor, Písek: Archeologický ústav AV ČR, Městský úřad v Sezimově Ústí, Husitské muzeum, Prácheňské nakladatelství.

Krumphanzlová, Z. 1965: Skleněné perly doby hradištní v Čechách. Památky archeologické LVI(1), 161-188. Dostupné tiež z: https://bit.ly/3D8whvb.

Kuna, M. 2015: Categories of settlement discard. In: K. Kristiansen, L. Šmejda, J. Turek (eds.): Paradigm found. Archaeological theory present, past and future. Essays in honour of Evžen Neustupný. Oxford: Oxbow Books, 278-292.

Kuna, M., Profantová, N. 2005: Počátky raného středověku v Čechách. Praha: Archeologický ústav AV ČR Praha.

Macháček, J. 2000: K absolutní a relativní chronologii keramiky středodunajské kulturní tradice na jižní Moravě. Sborník prací Filozofické fakulty brněnské univerzity M 5, 25-55.

Macháček, J. 2001: Studie k velkomoravské keramice. Metody, analýzy, syntézy a modely. Brno: Masarykova univerzita.

Malach, R. 2011: Raně středověké osídlení Lysické sníženiny a Malé Hané. Rkp. bakalárskej práce. Ústav archeologie a muzeologie. Filozofická fakulta. Masarykova univerzita. Uloženo: knihovna Ústavu archeologie a muzeologie Filozofické fakulty Masarykovy univerzity. Dostupné tiež z: https://is.muni.cz/th/mqv95/.

Marek, O., Kostelníková, M. 1998: Die Spinnwirtel aus Mikulčice. In: L. Poláček (Hrsg.): Studien zum Burgwall von Mikulčice III. Spisy Archeologického ústavu AV ČR Brno 11. Brno: Archäologisches Institut der Akademie der Wissenschaften der Tschechischen Republik, Brno, 171-326.
Marešová, K. 1985: Uherské Hradiště-Sady. Staroslovanské sídliště na Dolních Kotvicích. Uherské Hradiště: Okresní národní výbor Uherské Hradiště.

Mazuch, M. 2008: Slovanské sídliště v poloze Mikulčice „Podbřežníky“. Přehled výzkumů 49, 165-181. Dostupné tiež z: https://www.arub.cz/magazine/pv-49/.

Měřínský, Z. 2009: České země od příchodu Slovanů po Velkou Moravu I. Praha: Libri.

Miklíková, Z. 2010: Archeozoologické nálezy zo stredovekého sídliska v Bajči. Slovenská archeológia LVIII(1), 123-168. Dostupné tiež z: http://www.cevnad.sav.sk/aktivita_1_1/slovenska_ archeologia_2010_1.pdf.

Milo, P. 2014: Frühmittelalterliche Siedlungen in Mitteleuropa: eine vergleichende Strukturanalyse durch Archäologie und Geophysik. Studien zur Archäologie Europas 21. Bonn: Dr. Rudolf Habelt GmbH.

Nekuda, V. 2000: Mstěnice. Zaniklá středověká ves 3. Raně středověké sídliště. Brno: Muzejní a vlastivědná společnost, Moravské zemské museum.

Neustupný, E. 1986: Nástin archeologické metody. Archeologické rozhledy XXXVIII(5), 525-549.

Neustupný, E. 1994: Settlement area theory in Bohemian archaeology. In: J. Fridrich (ed.): 25 years of archaeological research in Bohemia. Památky archeologické, Supplementum 1. Prague: Institute of archaeology, 248-258.

Novák, Z., Hanžl, P. 1992: Geologické a geografické poměry. In: Medlánky (1237-1992). Brno-Medlánky: Obecní úřad, 5-7.

Ondráček, J., Přichystal, A. 2017: Svory jako surovina raně středověkých žernovů na hradišti Staré Zámky u Líšně. Acta Musei Moraviae, Scientiae sociales CII(2), 139-150.

Opravil, E. 1967: Die südmärischen Wälder im jüngeren Holozän. Praha: Academia.

Opravil, E. 1986: Dřevěné uhlí z hutnických dílen na Blanensku. In: V. Souchopová: Hutnictví železa v 8. - 11. století na západní Moravě. Studie Archeologického ústavu Československé Akademie věd v Brně VIII(1). Praha: Academia, 89-93.

Peacock, D. M. S. 1982: Pottery in the Roman World. London: Longman.

Piačková, K. 2018: Výskyt lidských skeletů $v$ sídlištních kontextech raného středověku na Moravě a ve Slezsku. Rkp. diplomovej práce. Ústav archeologie a muzeologie. Filozofická fakulta. Masarykova univerzita. Uloženo: knihovna Ústavu archeologie a muzeologie Filozofické fakulty Masarykovy univerzity. Dosupné tiež z: https://is.muni.cz/th/xe84g/.

Pleinerová, I. 1975: Břrezno. Vesnice prvních Slovanů v severozápadních Čechách. Praha: Academia.

Profantová, N., Profant, M. 2004: Encyklopedie slovanských bohư a mýtu. Praha: Nakladatelství Libri.

Procházka, R. 1992: Záchranný výzkum slovanského sídliště v Kuřimi, okr. Brno - venkov. Pravěk Nová řada 1992/2, 317-342.

Procházka, R. 2017: Hrad Přerov v raném středověku (9.-11. století) a počátky mladohradištní hmotné kultury. Spisy Archeologického ústavu AV ČR Brno 54. Brno: Archeologický ústav Akademie věd České republiky, Brno.

Procházka, R., Wihoda, M., Zapletalová, D. 2011: V raném středověku. In: R. Procházka (ed.): Dějiny Brna 1. Brno: Statutární město Brno, Archiv města Brna, 447-560.

Přichystal, A. 2009: Kamenné suroviny v pravěku. Východní část střední Evropy. Brno: Masarykova Univerzita.

Přichystal, A. 2011: Geologie brněnského prostoru. In: R. Procházka (ed.): Dějiny Brna 1. Brno: Statutární město Brno: Archiv města Brna, 17-39.

Přichystal, M. 2009: Brno (k. ú. Bohunice, okres Brno-město). Přehled výzkumů 50, 344. Dostupné tiež z: https://www.arub.cz/ wp-content/uploads/pv_50_2008_stredovek_a_novovek-1.pdf 
Přichystalová, R. 2010: Nerituálny pohreb muža z južného predhradia na Pohansku pri Břeclavi. In: Š. Ungerman, R. Přichystalová (eds.): Zaměřno na středověk. Zdeňkovi Měřínskému k 60. narozeninám. Praha: Nakladatelství Lidové noviny, 139-150.

Salaš, M., Stuchlík, S. 2011: Civilizace doby bronzové. In: R. Procházka (ed.): Dějiny Brna 1. Brno: Statutární město Brno, Archiv města Brna, 227-318.

Sotáková, M. 2007: Břeclav-Pohansko, poloha Lesní hrúd. Spracovanie a analýza fragmentov mazanice z výskumu r. 2003 a 2004. Rkp. diplomovej práce. Filozofická fakulta. Masarykova uiverzita. Uloženo: knihovna Ústavu archeologie a muzeologie Filozofické fakulty Masarykovy univerzity. Dostupné tiež z: https://is.muni.cz/th/65083/ff_m/.

Souchopová, V. 1986: Hutnictví železa v 8. - 11. století na západní Moravě. Studie Archeologického ústavu Československé Akademie věd v Brně VIII(1). Praha: Academia.

Souchopová, V. 1995: Počátky západoslovanského hutnictví železa ve světle pramenů z Moravy. Studie Archeologického ústavu Akademie věd České republiky v Brně XV(1). Brno: Archeologický ústav Akademie věd ČR v Brně. Dostupné tiež z: https://www.arub.cz/ wp-content/uploads/Pocatky_zapadoslovanskeho_hutnictvi-1.pdf.

Staňa, Č. 1960: Slovanské obytné objekty na hradišti Staré Zámky u Líšně. Památky archeologické LI(1), 240-293. Dostpné tiež z: https://bit.ly/3rixqy9.

Staňa, Č. 1972: Velkomoravské hradiště Staré zámky u Líšně. Stavební vývoj. Monumentorum Tutela - Ochrana pamiatok 8, 109-171.

Staňa, Č. 1985: Mährische Burgwälle im 9. Jahrhundert. In: H. Friesinger, F. Daim (Hrsg.): Die Bayern und ihre Nachbarn 2. Wien: Verlag der Österreichischen Akademie der Wissenschaften, 157-200.

Staňa, Č. 1994: Die Entwicklung der Keramik vom 8. bis zur Mitte des 11. Jahrhunderts in Mittelmähren. In: Č. Staňa (Hrsg.): Slawische Keramik in Mitteleuropa vom 8. bis zum 11. Jahrhundert. Internationale Tagungen in Mikulčice I. Brno: Archäologisches Institut der Akademie der Wissenschaften der Tschechischen Republik, 265-286.

Staňa, Č. 2010: Staré zámky u Líšně. Velkomoravské centrum Brněnska. Archeologické a historické vyhodnocení dosavadních výzkumü. Rkp. č. j. 2437/10, 2438/10. Uložené: archiv Archeologického ústavu AV ČR v Brně.

Staššíková-Štukovská, D. 2002: Korózia skla - príklad zo včasnostredovekého obdobia. In: D. Staššíková-Štukovská (ed.): História skla 2001. Nitra: Slovenská archeologická spoločnost’ pri Slovenskej akadémii vied, 47-48.

Šalkovský, P. 2001: Häuser in der frühmittelalterlichen slawischen Welt. Nitra: Archeologický ústav Slovenskej akadémie vied.

Šalkovský, P. 2002: Stavebná kultúra a urbanizmus osád. In: A. Ruttkay, M. Ruttkay, P. Šalkovský (eds.): Slovensko vo včasnom stredoveku. Nitra: Archeologický ústav Slovenskej akadémie vied, 57-68.

Šichnárková, S. 2014: Petrografický výzkum raně středověkých žernovů ze Znojma-Hradiště. Rkp. diplomovej práce. Ústav geologických věd. Přírodovědecká fakulta. Masarykova univerzita. Uloženo: knihovna Ústavu geologických věd Přírodovědecké fakulty Masarykovy univerzity. Dostupné tiež z: https://is.muni.cz/th/lmdgy/.

Unger, J. 2010: Lidské kosterní pozůstatky na sídlištích ve středověku. Možnosti interpretace. In: R. Tichý, O. Štulc (eds.): Hroby, pohřby a lidské pozůstatky na pravěkých a středověkých sídlištích. Živá archeologie, Suppl. 3. Hradec Králové: Katedra archeologie FF Univerzity Hradec Králové, 165-167.

Ungerman, Š. 2007: Raně středověké pohřebiště v Dolních Věstonicích-Na pískách. Rkp. dizertačnej práce. Ústav archeologie a muzeologie. Filozofická fakulta. Masarykova univerzita. Uloženo: knihovna Ústavu archeologie a muzeologie Filozofické fakulty Masarykovy univerzity. Dostupné tiež z: https://is.muni.cz/th/j4jc1/.
Váňa, Z. 1995: Přemyslovská Budeč. Archeologický výzkum hradiště v letech 1972-1986. Praha: Archeologický ústav Akademie věd České republiky.

Vařeka, P. 1995: Nálezy mazanic v archeologických strukturách deskriptivní systém a databáze mazanice. Archeologické fórum 4, 59-64.

Vařeka, P. 2001: Stavební kultura předhradí Levého Hradce. In: K. Tomková: Levý Hradec v zrcadle archeologických výzkumů. Díl 1. Castrum Pragense 4. Praha: Archeologický ústav Akademie věd České republiky, 254-271.

Vařeka, P. 2004: Archeologie středověkého domu. Plzeň: Katedra archeologie, FHS Západočeské univerzity v Plzni.

Zapletalová, D. 2001: Slovanské osídlení na území města Brna do 10. století. Rkp. diplomovej práce. Filozofická fakulta. Masarykova univerzita. Uloženo: knihovna Ústavu archeologie a muzeologie Filozofické fakulty Masarykovy univerzity.

Zavadilová, M. 2011: Die Baukultur des frühmittelalterlichen Zentralortes Pohansko bei Břeclav. Die Bedeutung der systematischen Ausgrabungen und neue Erkenntnisse. In: J. Macháček, Š. Ungerman (Hrsg.): Frühgeschichtliche Zentralorte in Mitteleuropa. Studien zur Archäologie Europas 14. Bonn: Verlag Dr. Rudolf Habelt GmbH, 105-118.

\section{Summary}

Although the early medieval settlement in Brno-Medlánky is not a site of great regional significance, it has provided many interesting finds and information. The settlement is situated on a moderate hill with loess subsoil in fertile lowland near the Svitava and Svratka rivers and was excavated in two phases (Zadní žleby site). The slope of the hill is oriented to the east and southeast and the site lies at an altitude of 260-265 metres above sea level. The closest stream of water - Medlánecký potok - currently canalised, is situated $750-800 \mathrm{~m}$ (as the crow flies) from the site. It is possible that its tributary used to flow along the southern side of the site in the past. Anthracological samples indicate that the site was located in the Oak-Beech-zone (Tab. 1) (Buček, Kirchner 2011, 47-50, 61, 67-68). The first phase of the rescue excavation was conducted in 1984, during the construction of the production hall for the national company $M e^{-}$ opta Prerov. The second phase was conducted in 2007 during the construction of MÚK Hradecká-Purkyñova ramp 2nd phase, an extension of the tram tracks leading to the cadastral territory of Královo Pole and Medlánky. Both excavations were conducted under the supervision of M. Geisler. The multi-period occupation is evidenced at the site, in addition to the finds from the Hillfort period, features from the Middle and Late Bronze Age, and possibly from the Early Bronze Age, were excavated (Geisler 1992, 1-2; Geisler 2008a, 1-7).

The settlement has provided us with an interesting and colourful set of Prague type pottery and pottery from the Middle Hillfort period; however, this does not apply to other types of finds. The pottery was analysed using the database of J. Macháček (2001, 42-66). This set has enabled us to date the settlement to the end of the 6th and the early 7 th century until the 10th century and to subdivide it relatively into the horizons RS1 (550-650), RS2 (650-800) and RS3 (800-950). The RS2 horizon was further divided into the earlier and later phase, due to the multiple presence of the Old Hillfort period pottery in this set. Conservative tendencies dominating the rural environment left a clear mark on the set, particularly in the production and decoration processes. Decorations resembling the Old Hillfort period pottery have, in multiple cases, occurred on the Middle Hillfort period pottery, partially characterised by the handmade and less profiled ending of the rims. The RS1 
horizon (Fig. 9) represents typical poorly fired ceramics of the Prague type that were handmade using very coarse material. However, this type of pottery occurred very rarely in the settlement and mostly in feature 93, which was dated by it. The RS2 horizon was divided into two phases. Phase 1 consisted of pieces with archaic incised decoration and a very irregular decoration incised with a comb-like tool. This phase had a similarly rare presence in the set like the RS1 horizon. On the contrary, Phase 2 forms the most numerous component of the assemblage. Coarse poorly fired pottery with simple rims and various comb-like and stroke decorations are typical for this phase. Nine pits could be dated to RS2(2). The last horizon, RS3, consisted of pottery with decoration incised with a single-prong instrument and regular decoration incised with a comb-like tool. In addition to simple rims, more complex rims, typical for the Great Moravian period, and finer material occur in this horizon. Eight pits could be dated to the last horizon. A more precise dating was possible only in the case of 18 pits in the whole set (exact dating of feature 111 based on its location is uncertain). In the set of ceramics from the settlement, further features of interest were noted. A high concentration of golden mica in the ceramic fabric, which served as a temper, is worthy of mention. The set included some pieces of Blučina type pottery imitations (Fig. 22: 9; 25: 16, 19; 29: 6, 20) while another piece probably belonged to the Dolní Věstonice pottery type. Examples of three mouldings (Fig. 13: 20; 17: 19; 26:33), the occurrence of which is rare before the Late Hillfort period, were of equal interest (Balcárková 2010, 172, 178).

The settlement did not differ from the typical Slavic rural oikumene in its structure and economic activity (Milo 2014, 690-695; Pleinerová 1975, 24-27). Utilising the GIS ArcMap program, a spatial structure of the settlement was created (Fig. 43). It probably had a typical cumulated built-up area of an arc shape from the northwest to the east, acquiring a scattered nature to the east direction. However, this is under debate, since the settlement has not yet been completely excavated. Due to the atypically large distance between the dwellings, the many residential features phenomenon is likely the cluster of two sunken-floored huts in the western part (Fig. 44). All of them have been safely dated to the Middle Hillfort period. This was most likely the centre of the settlement, which had continually spread. A cluster of storage pits was situated between the huts. One of the pits is dated to the Early Hillfort period and another to the Early Slavic period. The inhabitants of the huts had likely been using those pits collectively, as they were probably in a close family relationship. Therefore, we can assume that the core of the settlement was formed by one clan. More families, who were not part of the original clan, eventually joined the settlement, forming autonomous family units. A larger hut with a remarkably irregular floor plan dated to the RS3 horizon is worth mentioning. We documented two storage pits and another next to them. Two were also dated to RS3. We cannot say decisively if this hut formed a final isolated dwelling or it has persisted along with other dwellings because most of the features could not be dated with certainty. Considering the spatial development, I would rather be inclined towards the second scenario. A total of nine pithouses, the remaining aboveground structures and a total of 30 storage pits have been excavated. In the case of six huts, a stone furnace could be proven. In two cases, only the remains of a fireplace were present and one dwelling contained evidence of neither. By evaluating a limited set of daub, only wattle and timbered constructions were proven. No indication of courts or any other organised structures were found within the site, which is not unusual for the Eastern European rural environment in early medieval times.
Agricultural activity and animal production are evidenced in the settlement. The cultivation of crops is indirectly implied by the presence of storage pits, a roasting tray in feature 87 , four quernstones (Fig. 34) and their fragments. Bones from cattle, pigs, sheep, goats and poultry were present in the skeletal remains (Tab. 18). The community also had little engagement in hunting wildlife. Domestic processing of leather, bones and textiles was proven by four spindle whorls, seven bone awls and a semi-finished bone tip (Fig. 32: 1; 35, 36). Notably, evidence of minor iron metallurgy and blacksmithing could be proven by blacksmith and metallurgy slag and a charcoal pile (Fig. 6). The slag could be identified as metallurgical based on the morphology of the particular pieces and due to its typical chemical composition (Fig. 38, Tab. 21). The charcoal pile, feature 21, was identified based on its flat bottom shape, analogies from later periods, and a large accumulation of charcoals next to one of the walls (Kmošek 2011, 11-14, 42-44, Fig. 14-24). Despite the settlement being located relatively close to iron ore deposits in Moravský kras, we are unable to confirm if the processed iron ore originated there. Similarly, we do not have enough evidence to suggest large production. No evidence of specialised production or a production area could be found at the site either.

Indicators of an elite or a more complex social hierarchy are missing from the settlement. Except for a multi-coloured biconical glass bead (blue, yellow), the archaeological set did not contain any jewellery (Fig. 33). Two fragments of double-sided bone combs and three small iron knives were found, all part of the usual equipment of the common people, which provide no evidence of an elite class (Fig. 31: 1, 2; 32: 2, 3). This assumption is further supported by the ceramic material being poorly fired from coarse materials so therefore not resembling luxurious goods. The presence of a type of foreman can be indicated by a horse burial, which according to the deformations on its bones was a riding horse. As previously mentioned, the organisation of the houses demonstrates the presence of multiple families, of which the foreman was the leader.

Key phenomena in the settlement are animal burials (two dogs and one horse) and the burial of a human (Fig. 41) in a storage pit (Dreslerová 2020). All these burials are observed in the northern part of the area (Fig. 45). The horse, dogs and the human skeleton are situated on the edge of the settlement, although still relatively close to the inhabited area. On the contrary, a huge accumulation of animal bones in feature 112, where in addition to various animal skeletons, the preserved skeletons of a pig and a third dog were discovered, was located immediately next to the most northern pithouse. Therefore, we can assume that after its use as a storage pit, it was used as a waste pit. In the case of the burial of two dogs, we can assume that they were guard dogs or pets of a species similar to Doberman and Whipped/Fox Terrier. The marks of the cuts on the bone of one of those dogs might be indications of a fight. The horse buried in an anatomical position in pit 157 was buried in a similar pious manner. It was $150 \mathrm{~cm}$ tall and had snuffle marks on its jaw, as well as a deformation of its spine, which clearly prove it to be a riding horse (Dreslerová 2020, Fig. 11, 12). Probably the most interesting find is the burial of a human in storage pit 124 . Since the ceramic material is very unspecific, we cannot date it with certainty. The body was likely tossed and as the head was found $50 \mathrm{~cm}$ above the rest of the skeleton, the individual was most likely decapitated. He or she may have been a criminal (Piačková 2018, 61-62).

Based on the pottery derived from the Blučina type, the Middle Hillfort period fine pottery and the presence of a glass bead, we assume contacts with the regional Líšeň stronghold, even though claiming so with certainty, based only on the above-mentioned 
finds, would be inconclusive. More appropriate would be the logical assumption of this contact and the fact that the settlement was a part of a wider agricultural hinterland. The stronghold was the residence of elites, as well as a creator of trends, which continually spread to the surrounding area. Whether the derivate of the Blučina type pottery was made in the stronghold or the settlement as an imitation, remains an unanswered question. $\mathrm{Ru}^{-}$ ral settlements formed the most prominent type of settlement units of the Slavic world during the Early Middle Ages. Therefore, it remains topical to engage in the study and evaluation of the information they provide. I believe that this article, in its part, has expanded the information base of this topic and helped to broaden the mosaic of the early medieval occupation in the region of Brno.

\section{Kontakt}

\section{Jakub Benech}

Ústav archeologie a muzeologie

Filozofická fakulta, Masarykova univerzita

Arna Nováka 1

CZ-602 00 Brno

429062@mail.muni.cz 